Dredging Operations and Environmental Research Program

Soil Separation Mobile Treatment Plant Demonstration, Bayport Confined Disposal Facility, Green Bay, Wisconsin

Trudy J. Olin-Estes, Susan E. Bailey,

David W. Bowman, Dennis L. Brandon 
The contents of this report are not to be used for advertising, publication, or promotional purposes. Citation of trade names does not constitute an official endorsement or approval of the use of such commercial products.

The findings of this report are not to be construed as an official Department of the Army position, unless so designated by other authorized documents. 


\section{Soil Separation Mobile Treatment Plant Demonstration, Bayport Confined Disposal Facility, Green Bay, Wisconsin}

by Trudy J. Olin-Estes, Susan E. Bailey, Dennis L. Brandon

Environmental Laboratory

U.S. Army Engineer Research and Development Center 3909 Halls Ferry Road

Vicksburg, MS 39180-6199

David W. Bowman

U.S. Army Engineer District, Detroit

McNamara Federal Building

477 Michigan Avenue

Detroit, MI 48226-2575

Final report

Approved for public release; distribution is unlimited 


\section{Dredging:}

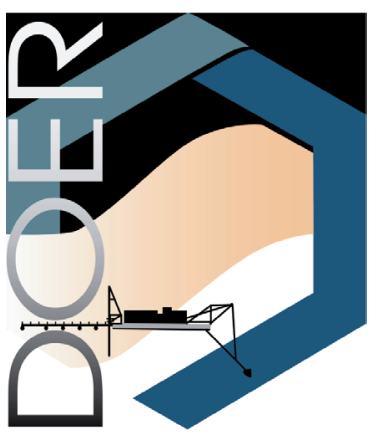

Soil Separation Mobile Treatment Plant Demonstration, Bayport Confined Disposal Facility, Green Bay, Wisconsin (ERDC/EL TR-02-38)

ISSUE: Confined disposal facilities (CDFs) have historically been used for disposal of both clean and contaminated dredged material from navigational dredging projects. Many CDFs are nearing capacity. Removal of uncomtaminated materials from the CDFs is a viable option for extending the life of these facilities. This approach carries the additional benefit of producing a marketable product for beneficial uses, which can potentially help to offset the cost of processing.

RESEARCH: The feasibility of physical separation as a volume reduction method has been demonstrated at several disposal facilities. A guidance document addressing principles of physical separation as they apply to soils and sediments, and identifying standard equipment, selection criteria, and potential sources was recently completed. Technical notes addressing recovery of materials from CDFs were also published under the Dredging Operations and Environmental Research (DOER) program. Work is ongoing at the U.S. Army Engineer Research and Development Center, funded under the DOER program, to develop bench-scale methods for economical preliminary feasibility evaluations.

SUMMARY: Preprocessing and separation equipment were tested in a one-day demonstration at Green Bay, WI. A 24-in. (0.6-m) maximum density separator was used to separate sand from the bulk sediment. The target sand product specifications were less than 10 percent fines by mass and polychlorinated biphenyls (PCBs) concentrations less than $1 \mathrm{mg} / \mathrm{kg}$. The underflow fraction averaged over 92 percent sand, as measured by a Coulter Counter. PCBs were reduced to $0.144 \mathrm{mg} / \mathrm{kg} \mathrm{PCB} 1242$ and $0.0119 \mathrm{mg} / \mathrm{kg} \mathrm{PCB} 1260$ in the sand, from $2.71 \mathrm{mg} / \mathrm{kg}$ and $0.145 \mathrm{mg} / \mathrm{kg}$ in the feed material, respectively. Based on statistical analysis of the results, the contaminant concentrations predicted for the sand fraction by the bench-scale testing were essentially equivalent to that achieved in the field operation. Distribution of metals was somewhat more variable than for PCBs, but metals were reduced by a factor of 2.6 to an order of magnitude in the sand fraction.

AVAILABILITY OF REPORT: The report is available in .pdf format on the World Wide Web at: http://www.wes.army.mil/el/dots/doer/ and through Interlibrary Loan Service from the U.S. Army Engineer Research and Development Center (ERDC) Research Library, telephone (601) 634-2355, or the following Web site: http://libweb.wes.army.mil/index.htm.

About the Authors: Study Investigators were Mmes. Trudy J. Olin-Estes, Research Civil Engineer, and Susan E. Bailey, Environmental Engineer, Environmental Laboratory, U.S. Army Engineer Research and Development Center; Mr. David W. Bowman, Physical Scientist, U.S. Army Engineer District, Detroit; and Dr. Dennis L. Brandon, Statistician, Environmental Laboratory.

Point of Contact: Dr. Robert M. Engler, Program Manager of the Dredging Operations and Environmental Research Program, (601) 634-3624, Robert.M.Engler@erdc.usace.army.mil. 


\section{Contents}

Preface viii

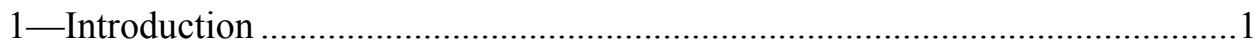

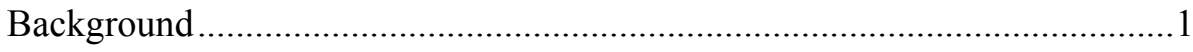

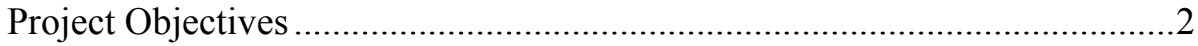

Identification of Available Equipment Types and Vendors........................... 3

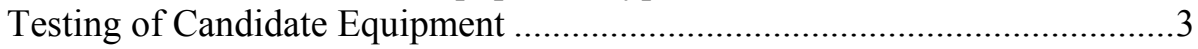

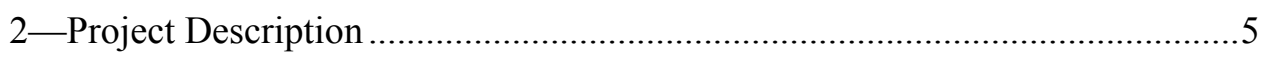

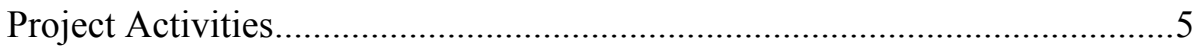

Field Sampling and Sample Handling ................................................... 8

Characterization and Bench-Scale Testing ................................................. 9

Cell 5 characterization and bench-scale testing ..................................... 9

Cell 4 characterization and bench-scale testing .....................................13

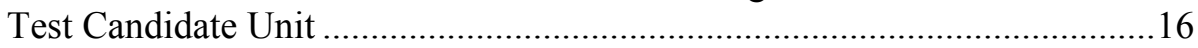

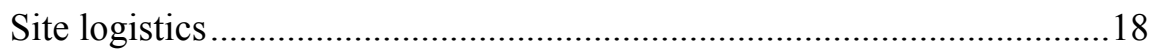

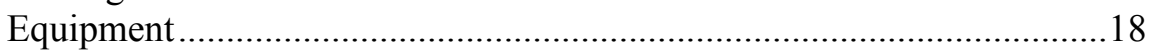

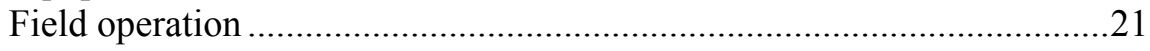

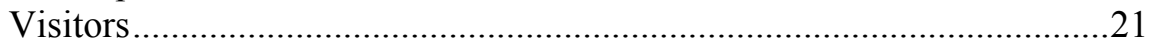

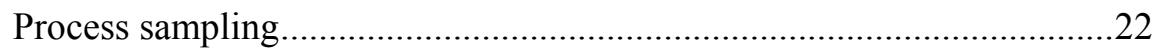

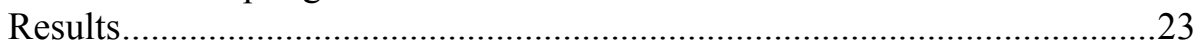

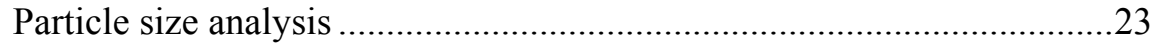

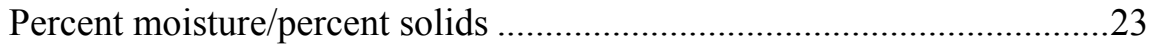

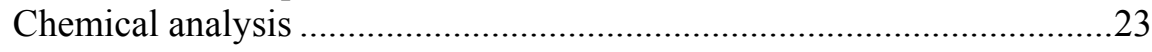

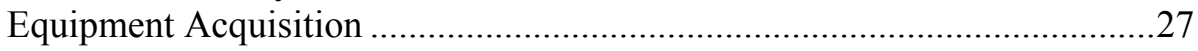

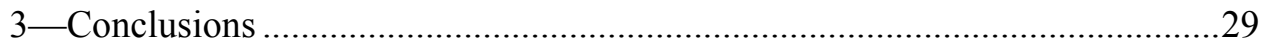

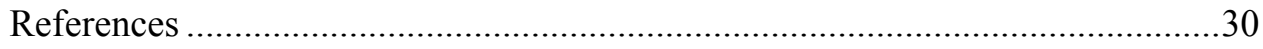

Appendix A: Coulter Counter Particle Size Analysis, Cell 4 Material ...............A1

Appendix B: Statistical Analysis of Results.................................................. B1 
Appendix C: Chemical Analysis Sample Listing, Data Validation,

Raw Data Sheets

SF 298

\section{List of Figures}

Figure 1. Green Bay Bayport CDF …...............................................6

Figure 2. PAH versus oil and grease concentrations, Cell 5

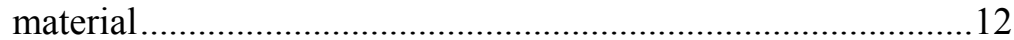

Figure 3. PCB versus oil and grease concentrations, Cell 5

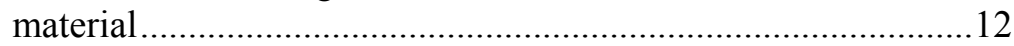

Figure 4. Metals versus oil and grease concentrations, Cell 5 material

Figure 5. Metals versus TRPH and oil and grease concentrations, Cell 4 material

Figure 6. $\quad$ PCB versus TRPH and oil and grease concentrations, Cell 4 material ...................................................17

Figure 7. PCB versus TOC concentrations, Cell 4 material .......................18

Figure 8. MetPro mobile MDS unit .........................................................19

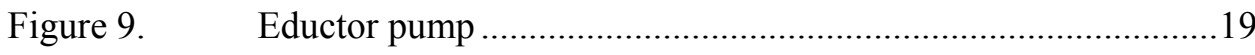

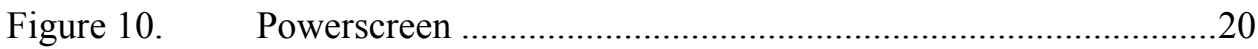

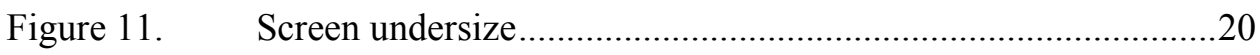

\section{List of Tables}

Table 1. Green Bay Cell 5 Chemical Analysis of Bulk

Sediment, Size, and Density Fractions ......................................10

Table 2. Particle Size Analysis of Green Bay Cell 5

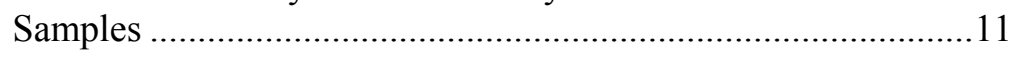

Table 3. Particle Size Analysis of Green Bay Cell 4

Samples .14

Table 4 Chemical Analysis of Cell 4 Bulk and

Fractionated Sediment Samples 
Table 5. Particle Size Analysis of Streams from the Mobile Hydrocyclone Demonstration.....

Table 6. Percent Moisture and Percent Solids of Process

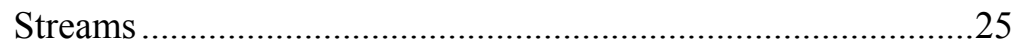

Table 7. Process Streams Chemical Analysis..........................................26

Table B1. Sand and Underflow Summary ….............................................

Table B2. Sand and Underflow T-Test Results ........................................ B5

Table B3. Sand and Underflow Equality of Variance Test

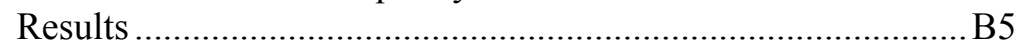

Table B4. Fines (Silt/Clay) and Overflow Summary ................................B6

Table B5. Fines (Silt/Clay) and Overflow T-Test Results ......................... B7

Table B6. $\quad$ Fines (Silt/Clay) and Overflow Equality of Variances Test Results ............................................................

Table B7. Bulk and Feed Summary ........................................................ B8

Table B8. Bulk and Feed T-Test Results ……......................................... 9

Table B9. Bulk and Feed Equality of Variances Test

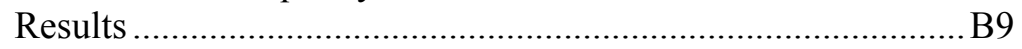

Table C1. Green Bay Physical Separation Samples - ECB

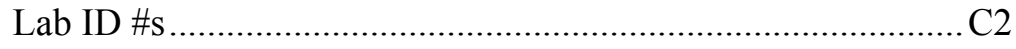

Table C2. Data Validation Summary ….................................................... 3 


\section{Preface}

This report summarizes the evaluation of a special hydrocyclone configuration (the maximum density separator) for physical separation of sediments, and corresponding efforts to develop simplified, representative, bench-scale procedures for preliminary testing. This project was jointly funded by the U.S. Environmental Protection Agency Great Lakes National Program Office (GLNPO), GLNPO Identification No. GL98079, IAG 14947887-01, and the U.S. Army Corps of Engineers Dredging Operations and Environmental Research (DOER) Program under Work Unit 0054PD.

This report was prepared by Mmes. Trudy J. Olin-Estes and Susan E. Bailey, Environmental Engineering Branch (EEB), Environmental Processes and Engineering Division (EPED), Environmental Laboratory (EL), Vicksburg, MS, U.S. Army Engineer Research and Development Center (ERDC); Dr. Dennis L. Brandon, Environmental Risk Assessment Branch (ERAB), EPED; and Mr. David Bowman, U.S. Army Engineer District, Detroit, MI. Project manager for GLNPO was Mr. Scott Cieniawski. Mr. Jan Miller, U.S. Army Engineer Division, Great Lakes and Ohio River, served as Corps liaison to GLNPO. Technical review was provided by Dr. Lawrence Jones, OA Systems, and Mr. Mitch A. Granat, U.S. Army Engineer District, Jacksonville, Jacksonville, FL.

The research was conducted under the general supervision of Mr. Daniel E. Averett, Chief, EEB; Dr. Bobby L. Folsom, Jr., Chief, ERAB; and Dr. Edwin A. Theriot, Chief, EL. 
At the time of publication of this report, Dr. James R. Houston was Director of ERDC, and COL John W. Morris III, EN, was Commander and Executive Director.

This report should be cited as follows:

Olin-Estes, T. J., Bailey, S. E., Bowman, D. W., and Brandon, D. L. (2002). "Soil separation mobile treatment plant demonstration, Bayport Confined Disposal Facility, Green Bay, Wisconsin," ERDC/EL TR-02-38, U.S. Army Engineer Research and Development Center, Vicksburg, MS. 


\section{Introduction}

\section{Background}

Confined disposal facilities (CDFs) have historically been used for disposal of both clean and contaminated dredged material from navigational dredging projects where open-water disposal was not permitted. Many CDFs are nearing capacity. Removal of uncontaminated materials from the CDFs is a viable option for extending the life of these facilities. This approach carries the additional benefit of producing a marketable product for beneficial uses, which can potentially help to offset the cost of processing. Use of CDFs as rehandling facilities, with long-term storage for only the most contaminated sediments, is being investigated by the U.S. Army Engineer Research and Development Center (ERDC), in partnership with the U.S. Army Engineer District, Detroit, the Great Lakes National Program Office (GLNPO) of the U.S. Environmental Protection Agency (USEPA), and local port authorities.

The feasibility of physical separation as a volume reduction method has been demonstrated at Saginaw Bay (USEPA 1994), the Erie Pier CDF, Duluth/ Superior Harbor (Olin and Bowman 1996) and Fort Myers, Florida (Granat 1998). Despite successful demonstrations at these locations and continued interest in the technology, physical separation has not yet been implemented as a standard operational practice, with the exception of the Erie Pier CDF. In part, this is due to the lack of internal expertise regarding physical separation and feasibility determinations, the cost of feasibility evaluations, and equipment availability.

A guidance document addressing principles of physical separation as they apply to soils and sediments, and identifying standard equipment, selection criteria, and potential sources was completed (USEPA 1999b). Technical notes addressing recovery of materials from CDFs were also completed under the Dredging Operations and Environmental Research (DOER) program (Olin-Estes and Palermo 2000a,b; Olin-Estes 2000). Work is ongoing at ERDC, funded under the DOER program, to develop bench-scale methods for economical preliminary feasibility evaluations. While bench-scale testing is a necessary first step, the limited volume of material that can be tested with these procedures cannot provide information regarding the potential heterogeneities of large quantities of material. Industry practice is to follow bench-scale testing with evaluation of an intermediate volume of material using a representative unit operation, such as a hydrocyclone. If these results are promising, a preliminary 
treatment train is assembled and pilot-scale testing is conducted in the field. Costs to contract intermediate and pilot testing are typically high given that mobilization/demobilization and equipment costs are relatively insensitive to the volume being processed, and most vendors cannot accept contaminated sediments for pilot testing in-house. Availability of a mobile hydrocyclone unit could result in significant cost savings for feasibility evaluations and small-scale projects, and ultimately facilitate full-scale implementation of this technology. The long-term goal is assemble a mobile physical separation plant suitable for separation of sediments and dredged material to serve the Great Lakes CDFs.

Questions remaining to be addressed before full-scale implementation is feasible include the following:

a. The degree of bulking of residual materials, with and without flocculants, and the short- and long-term effects on CDF capacity recovery.

b. Alternatives for dewatering residual materials to minimize bulking effects, and their cost, effectiveness, and effect on suitability of residual materials for beneficial uses.

c. The relative benefit and feasibility of making finer separations (silt/clay) to recover additional material from CDFs.

d. Evaluation procedures for determining the potential contaminant levels in fine residuals and the effect on the regulatory classification of these materials.

e. Development of cost/benefit algorithms incorporating all of these considerations for economic feasibility evaluations.

\section{Project Objectives}

Identification and purchase of a portable hydrocyclone unit suitable for conducting separation feasibility evaluations and a small-scale field demonstration was the principal objective of this project. While the predominant focus is coarse material recovery for beneficial use as beach nourishment and construction fill (typically requiring the material to contain less than 1015 percent fines), some beneficial uses will accommodate higher percentages of fine material. The silt/clay separation is expected to be an important long-range objective in maximizing material recovery from CDFs for material in which the silt fraction is substantially less contaminated than the clay fraction. Separation capability at the sand/silt interface (approximately 75 microns) with the additional capability of a silt/clay separation (at 2-3 microns) were therefore the principal operating specifications. Additional criteria were (a) level of expertise required for operation, (b) auxiliary equipment required to support operation, and (c) material preparation required. The equipment may also be used to address other information gaps, as previously described. 


\section{Identification of Available Equipment Types and Vendors}

A wide variety of equipment is marketed for size and density separations within the mining industry. However, the equipment is typically designed for coarser and higher density materials. Although there is a significant body of knowledge pertaining to the principles of operation of individual pieces of equipment, there is little guidance in developing a treatment train for processing soils and sediments. Fines, often termed slimes, are considered an operational problem in the mining industry, and are removed as a waste stream prior to making the principal separations. Contaminated sediment separations, however, involve making efficient separations near or within that "waste" fraction, and require the ability to handle and even recover the finest residuals. The condition of the materials presented to the plant will be highly variable, depending upon whether they are consolidated materials excavated from a CDF, or mechanically or hydraulically dredged sediments processed at the time of disposal. In situ water content may vary from 50 to 150 percent, presenting difficulty in handling and in processing through equipment designed for dry (less than 10 percent moisture content), or noncohesive, material. Previous testing of laboratory-scale mining equipment has demonstrated that the feed limitations are not always well defined, and the normal operating parameters may not interface well with the separations of interest for soils and sediments. Even among Architect/Engineer firms with experience in soil washing, assemblage of a treatment train appears to be something of an art, with the configuration varying depending upon specific site conditions. The result is an unacceptable number of operational unknowns for the layman and highly localized expertise within the consulting industry, which ultimately translates to prohibitive cost.

The significant objective of this phase of the project then was to evaluate how the equipment industry has responded to the potential in the sediment remediation arena: identifying the critical core pieces of equipment necessary for the key separations of interest and the minimum necessary auxiliary equipment required in support. The desired outcome is a portable testing unit that (a) is economical to purchase and operate, (b) can be supported with widely available equipment, (c) is adaptable to operational conditions and constraints at different facilities, and (d) is technically simple, operable by field personnel with a reasonable amount of preliminary instruction and technical support.

\section{Testing of Candidate Equipment}

The core unit to be evaluated under this project was a hydrocyclone separator. Performance factors for the equipment considered for demonstration and purchase were as follows:

a. The experience of the offeror in conducting size separation studies with dredged material and/or soil.

b. Suitability of the equipment to separate sediment/soil at the $75-\mu \mathrm{m}$ target size cutoff. 
c. Capability to produce a dewatered coarse product.

d. Suitability of the equipment to handle a variety of sizes and types of dredged material.

e. Portability of the unit.

f. Capacity of the unit.

g. Cost of the unit.

h. Cost of the demonstration.

$i$. Auxiliary equipment and site preparation requirements and costs.

j. Technical expertise required for operation.

$k$. Compatibility of equipment capacity with available storage area, water handling capability, and material preparation and feed capability at the demonstration site.

Preparation and auxiliary equipment requirements, adaptability, and technical expertise requirements were all relatively readily determined from product/offeror information and equipment design. Feed sensitivity and separation efficiency are best evaluated based on a performance test. It was anticipated that potential operational difficulties in this application and considerations of scale and logistics should come to light as a result of the demonstration. Samples were to be taken over a reasonable operating period to permit an assessment of the efficiency of the unit in making the desired separation, response to feed variations (if any), and the variability of the product material. A successful test would meet the separation criteria in a dewatered product, with a minimum of operational problems, at the specified efficiency. For the proposed demonstration, the specified cut point was $75 \mu \mathrm{m}$, with no more than 10 percent fines (percent by weight passing a No. 200 sieve) in the underflow. 


\section{Project Description}

The Bayport CDF in Green Bay, WI (Figure 1), was selected as the field demonstration site. Green Bay is located on the eastern shoreline of Wisconsin, on Lake Michigan. Approximately $115,000 \mathrm{cu} m(150,000 \mathrm{cu}$ yd) of sediment are dredged annually, to maintain the 29-km- (18-mile-) long shipping channel in the Port of Green Bay. The Bayport disposal facility was filled to design capacity in the early 1970's. Brown County sought and received authorization to dispose of additional dredged material there. Current operations involve mechanical dredging, with transport and offloading at the CDF by truck. To extend the life of the facility as long as possible, material is periodically removed from the facility, following a period of dewatering. The facility is divided into separate cells to permit offloading, dewatering, excavation, and stockpiling to occur concurrently. The Brown County Port Authority has taken an active interest in innovative management alternatives for dredged material, and the Bayport CDF was also recently the site of a biotreatment demonstration.

\section{Project Activities}

ERDC physical separation equipment available for demonstration/testing support was inventoried and its operational status verified. Response to an advertisement for technical support in identification of equipment alternatives and sources and development of a basic treatment train was limited (one firm responded) and exceeded the project budget for this task area. An extensive inhouse effort was therefore initiated to locate off-the-shelf equipment, and to identify those firms with interest in conducting a small demonstration and with availability of suitable scale equipment for preliminary field evaluation. Of the vendors contacted, only two indicated an interest in bringing equipment onsite for a small-scale demonstration: Tri-Flo Industries, Ltd., of Conroe, TX, and MetPro Supply, Inc., of Bartow, FL. Only one, MetPro Supply, responded to the advertisement for bids.

Tri-Flo Industries manufactures mobile, self-contained, fluid-processing equipment. Initially targeting the drilling industry, hydrocyclones mounted in series to a prefabricated header can be purchased, as well as complete, mobile, micro-fluid systems (MFS) designed for drilling mud recovery. These systems include a sump, mud "guns" for maintaining sediment in suspension, a shaking screen, hydrocyclones, and pumps. The configuration appears to have potential for sediment separation, but prescreening of gross oversize and slurrying of consolidated material would likely be needed to utilize the equipment as 


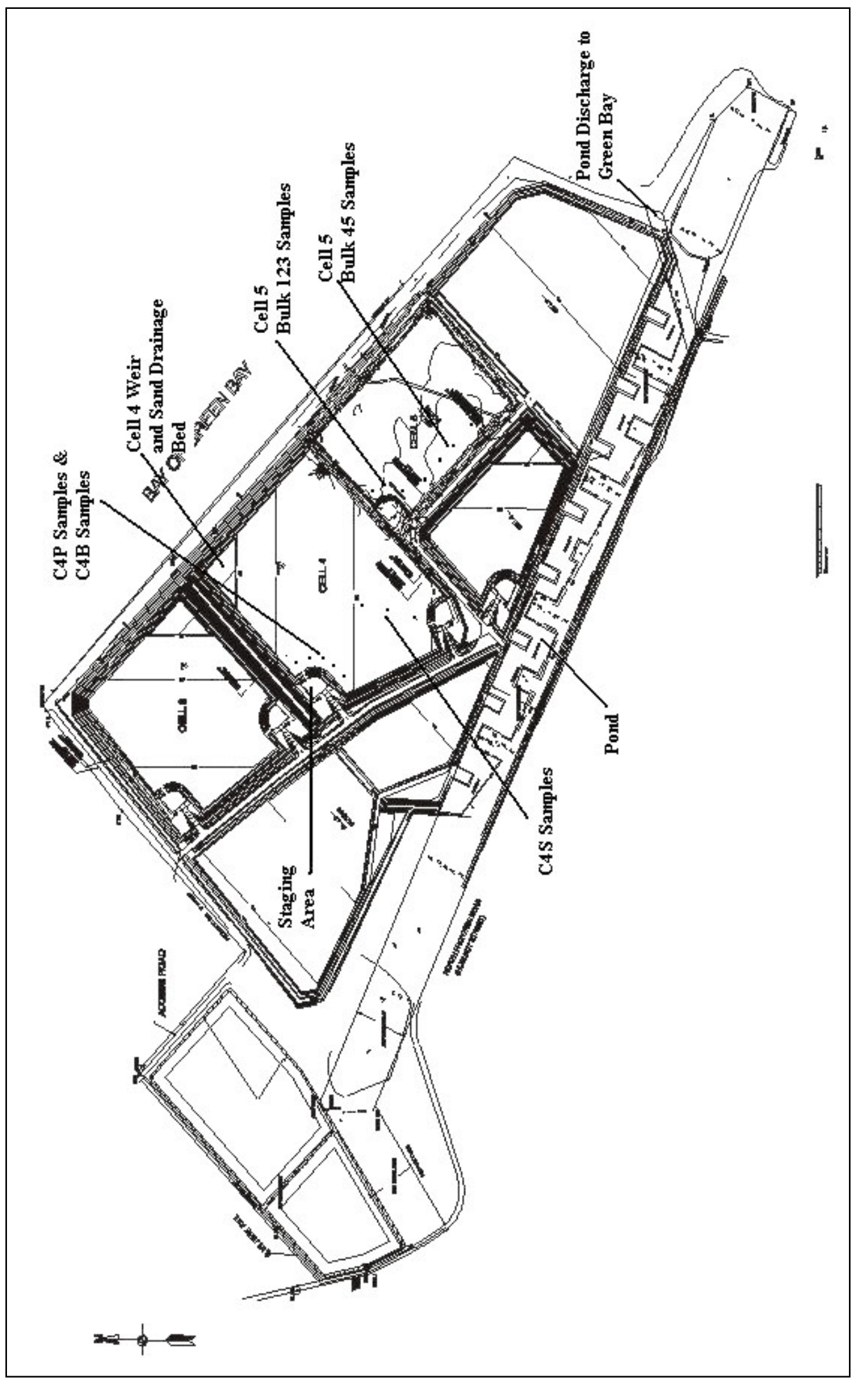

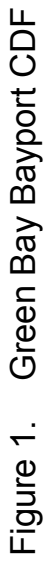


presently equipped. One advantage to the configuration was the potential for making the sand/silt separation on the screen, followed by a finer cut at the hydrocyclones, thus addressing both size separations of principal interest with one unit. Tri-Flo also manufactures a mud pump that could be useful for excavating and slurrying consolidated material. The mud pump is equipped with an integral screen that prevents the pump from picking up oversize particles. Principal limitations of the equipment were the potential for blinding of the screens, the inability of screens to separate coarse organic materials from coarse minerals, and the fact that this equipment has not been demonstrated for dredged material or sediments.

MetPro Supply manufactures a self-contained maximum density separator (MDS) consisting of a trailer-mounted sump, slurry pump, and MDS. Both 0.15and 0.3-m (6- and 12-in.) MDS have been demonstrated on sediments in the U.S. Army Engineer District, Jacksonville. Based on previous testing, MetPro recommended a $0.61-\mathrm{m}$ (24-in.) MDS to produce a coarse fraction with less than 10 percent fines entrained. A $0.61-\mathrm{m}$ (24-in.) MDS has a throughput of approximately $4.5 \mathrm{cu} \mathrm{m}(1,200 \mathrm{gal})$ per minute (approximately $68,039 \mathrm{~kg}$ (75 tons) solids per hour), and can accept particles up to $25-38 \mathrm{~mm}(1-1-1 / 2 \mathrm{in}$.) in diameter, thus simplifying prescreening. Dry or slurried material could be fed to the sump, with adjustments to the volume of makeup water supplied. The MDS differs from a conventional hydrocyclone in that a flexible sleeve is attached to the apex of the cone, and a vacuum is applied to the overflow line, thus restricting discharge of underflow until sufficient weight accumulates to force discharge. This reportedly results in a higher solids underflow.

Because of the potential variability in feed requirements, the offerors were tasked with providing the necessary auxiliary equipment to support the proposed separation unit, in effect developing a compatible treatment train. Mechanical excavation and prescreening were to be handled by the Detroit District. Auxiliary equipment was located in the Green Bay/Milwaukee area. A powerscreen for prescreening material; water supply pump; flexible, quickcoupling water hoses; and generator were available and obtained as short-term rentals.

Because the target separation of the proposed equipment was $75 \mu \mathrm{m}$, it was necessary to locate material containing sufficient sand to permit evaluation of the efficiency of the equipment in making this separation. Based on anecdotal information, Cell 5 was initially identified as containing sandy material from the outer harbor. Core and near-surface bulk samples were taken from Cell 5 for evaluation. However, finer material had apparently been placed over the target material, and the near-surface dredged material contained little sand. Additional samples were therefore taken for evaluation from Cell 4, where additional coarse material had recently been placed. (This material was from an inner harbor dredging project, and may not be representative of outer harbor sandy sediments). ${ }^{1}$ Sampling, sample handling, and bench-scale testing are further detailed in subsequent sections of this report. Approximately $380 \mathrm{cu} \mathrm{m}$ (500 cu yd) were

\footnotetext{
${ }^{1}$ Dean Haen, Personal Communication, 5 November 2001, Port Manager, Brown County Port and Solid Waste Department (Port of Green Bay), Green Bay, WI.
} 
also excavated from Cell 5 for evaluation of material handling properties and effects of debris on ease of excavation as part of a cooperative effort funded under the DOER program. Some of this material was processed through the powerscreen to evaluate performance of a dry screen with wet of optimum material, and to evaluate the feasibility of feeding the hydrocyclone using mechanical excavation and prescreening. A smaller volume of material was excavated from Cell 4 for comparative processing through the screen. The remainder of the Cell 4 excavation was accomplished hydraulically, at the time of the demonstration.

\section{Field Sampling and Sample Handling}

Nineteen 25.4-mm- (1-in.-) diameter cores were taken from Cell 5 of the Bayport CDF (Figure 1) to assess moisture content of the material initially proposed for processing. The cores were taken from along the truck dump and the south dike, areas accessible for mechanical excavation, using an AMS Soil Core Sampler with slide hammer, including stainless steel soil collector, and 25.4- by $0.6-\mathrm{mm}$ (1- by 24 -in.) butyrate plastic liners with polyethylene caps. (Although 0.6-m (24-in.) tubes were used, in many cases only $0.15-0.5 \mathrm{~m}$ (618 in.) of dredged material was recovered due either to the compressibility of the material or the inability to drive the sampler deeper.) Five 19-L (5-gal) samples intended for bulk sediment chemistry and fractionation testing were taken along the same perimeter and placed in high-density polyethylene (HDPE) buckets, using a shovel decontaminated with acetone and distilled deionized (DDI) water between samples. Each bucket was placed in a cooler and packed in ice for shipment. Chain-of-custody forms were placed inside the coolers and coolers were sealed with tape and chain-of-custody seals. Chain-of-custody seals were intact upon receipt at the laboratory. Temperatures of the samples upon arrival were below $4{ }^{\circ} \mathrm{C}\left(1.7\right.$ to $\left.3.3{ }^{\circ} \mathrm{C}\right)$, with the exception of Bucket 4 , which was $5^{\circ} \mathrm{C}$. Core samples were not intended for chemical analysis and were therefore not refrigerated. They were left in the disposable plastic liners and shipped together in a cooler for later extrusion.

Before samples were taken from Cell 4, representative material was screened in the field to verify the presence of sand. Based on the field screening, the Cell 4 material along the northwest truck dump was roughly estimated to contain $40-50$ percent sand. Samples were subsequently taken for laboratory analysis along the northwest truck dump (adjacent Cell 2), and along a radius from the southwest truck dump (adjacent Cell 5 and the road) toward the outlet. Because this was a duplicate effort, a repeat full-scale sampling effort was not feasible. Smaller sample volumes were therefore obtained during a subsequent site visit and progress meeting.

Twelve 0.9-L (1-qt) glass jars were obtained from Cell 4: three for bulk chemical analysis (C4B1-C4B3), six for particle size analysis (C4P1-C4P6) from the perimeter of the northwest truck dump, and three (C4S1-C4S3) for particle size analysis along the inner radius. Sample preservation and chain of custody were observed as for the Cell 5 samples. 


\section{Characterization and Bench-Scale Testing}

\section{Cell 5 characterization and bench-scale testing}

The three 19-L (5-gal) samples taken from along the truck dump were mixed together (Buckets 1, 2 and 3 identified hereafter as Bulk 123 composite) and homogenized. The two 19-L (5-gal) samples taken along the dike (Buckets 4 and 5 identified as Bulk 45 composite) were also combined and homogenized. Wet chemistry, moisture content, and particle size distribution were evaluated on both composites. Because these parameters were relatively comparable for the two composites, one was selected for fractionation testing, rather than compositing the total volume. Bulk 123 was selected because of the greater accessibility of the area from which those buckets were taken, and the greater likelihood that they would be excavated. The cores were extracted from the plastic tubes, and samples were taken for water content analysis.

Particle size analysis. Subsamples of the Bulk 123 and Bulk 45 composites were analyzed on the Coulter particle size analyzer. Both composites contained over 90 percent fines.

Bulk sediment chemistry. The Bulk 123 composite and Bulk 45 composite were analyzed for polychlorinated biphenyls (PCBs), polycyclic aromatic hydrocarbons (PAHs), metals, total organic carbon (TOC), total recoverable petroleum hydrocarbons (TRPH), and oil and grease $(\mathrm{O} \& \mathrm{G})$ (the latter three being potential indicator compounds). Results are summarized in Table 1. Concentrations were comparable for all analytes for both composites.

Water content analysis. The core samples ( 44 total) were analyzed in duplicate for water content $\left(\mathrm{w}=\left(\mathrm{M}_{\text {water }} / \mathrm{M}_{\text {solids }}\right) * 100\right)$ by oven drying. The average water content was $112.4 \pm 24.6$ percent. Water content of the Bulk 123 and Bulk 45 composites averaged 98.7 and 82.2 percent, respectively.

Fractionation testing. Approximately $10.5 \mathrm{~kg}$ (wet weight) of the Bulk 123 sample was wet sieved through a $75-\mu \mathrm{m}$ sieve for analysis of the sand $(>75 \mu \mathrm{m})$ and fines $(<75 \mu \mathrm{m})$ fractions. The resultant slurries were centrifuged and the solids retained for particle size and chemical analysis. Both fractions were analyzed on the Coulter LS100 Particle Size Analyzer to determine the efficiency of the separation. The results (Table 2) show that the fines were not very effectively removed from the sand. Further separation of the clay and silt from a subsample of the fines was attempted using an upflow column. The clay was never effectively removed from the fines, and the samples were therefore not further analyzed.

Additionally, a subsample of the Bulk 123 was fractionated by density using heavy media separation in order to analyze the contaminant differences between mineral and organic sediment material. In this procedure, the sediment was combined with a solution of sodium polytungstate at a specific gravity of 2.0. The mixture was briefly sonicated and then centrifuged to separate the density fractions. The material heavier than 2.0 specific gravity (mineral) sank to the bottom, and the lighter fraction (organic) floated on top of the solution and was 


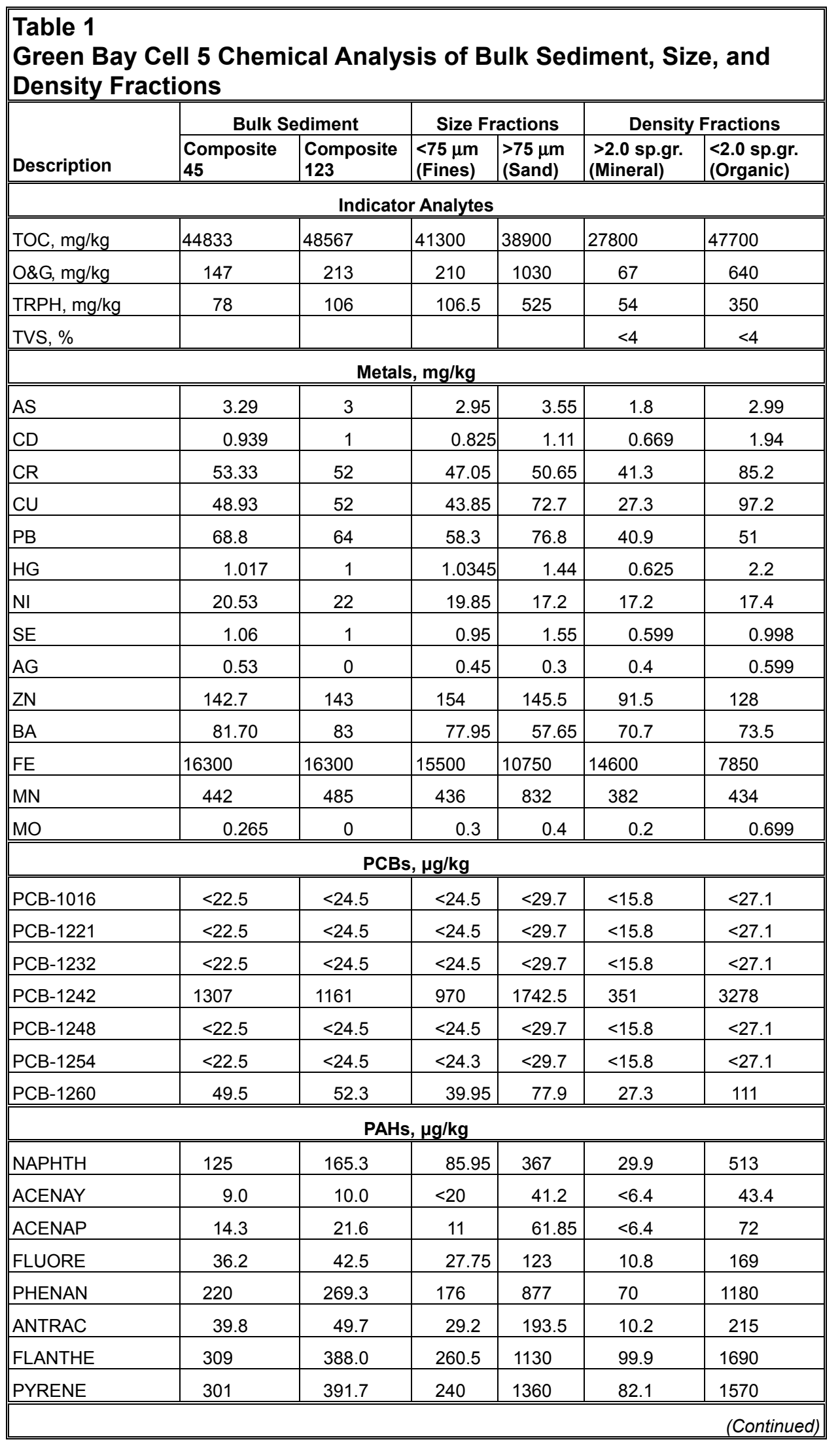




\begin{tabular}{|c|c|c|c|c|c|c|}
\hline \multicolumn{7}{|c|}{ Table 1 (Concluded) } \\
\hline \multirow[b]{2}{*}{ Description } & \multicolumn{2}{|c|}{ Bulk Sediment } & \multicolumn{2}{|c|}{ Size Fractions } & \multicolumn{2}{|c|}{ Density Fractions } \\
\hline & \begin{tabular}{|l|} 
Composite \\
45 \\
\end{tabular} & \begin{tabular}{|l|} 
Composite \\
123
\end{tabular} & $\begin{array}{l}<75 \mu \mathrm{m} \\
\text { (Fines) }\end{array}$ & $\begin{array}{l}\begin{array}{l}>75 \mu \mathrm{m} \\
\text { (Sand) }\end{array} \\
\end{array}$ & $\begin{array}{l}\text { >2.0 sp.gr. } \\
\text { (Mineral) }\end{array}$ & $\begin{array}{l}<2.0 \text { sp.gr. } \\
\text { (Organic) }\end{array}$ \\
\hline \multicolumn{7}{|c|}{ PAHs, $\mu \mathrm{g} / \mathrm{kg}$ (Concluded 0} \\
\hline CHRYSE & 192 & 247.7 & 152 & 850 & 66.2 & 992 \\
\hline BAANTHR & 139 & 180.3 & 97.95 & 756 & 29.9 & 720 \\
\hline BBFLANT & 127 & 173.3 & 112.5 & 565 & 53.4 & 762 \\
\hline BKFLANT & 101 & 139.0 & 76.35 & 463.5 & 32.4 & 521 \\
\hline BAPYRE & 149 & 193.3 & 108.45 & 769 & 35.6 & 747 \\
\hline I123PYR & 122 & 164.3 & 99.45 & 540 & 39.4 & 637 \\
\hline DBAHANT & 26.6 & 29.2 & 19.5 & 114 & 5.1 & 105 \\
\hline B-GHI-PY & 149 & 179.3 & 112.5 & 614 & 48.3 & 678 \\
\hline 2MeNAPH & 130 & 157.7 & 98.95 & 426 & 31.8 & 574 \\
\hline
\end{tabular}

\begin{tabular}{|c|c|c|c|c|}
\hline \multicolumn{5}{|c|}{\begin{tabular}{|l} 
Table 2 \\
Particle Size Analysis of Green Bay Cell 5 Samples
\end{tabular}} \\
\hline Volume, \% & Bulk 45 & Bulk 123 & Sand & Fines \\
\hline$<5 \mu \mathrm{m}$ & 27.1 & 24.3 & 25.88 & 30.5 \\
\hline$<75 \mu \mathrm{m}$ & 93.3 & 90.8 & 43.5 & 99.98 \\
\hline$>75 \mu \mathrm{m}$ & 6.70 & 9.2 & 56.5 & 0.02 \\
\hline
\end{tabular}

removed. The procedure was repeated several times to ensure a reasonably clean separation, as determined by visual inspection.

The four fractionated samples (fines, sand, mineral, organic) were analyzed for PAHs, PCBs, metals, and indicator analytes. Density (mineral and organic) samples were also analyzed for total volatile solids (TVS) to assess efficiency of separation, but this parameter was ultimately not useful, being less than the detection limit (DL) for both fractions. Results are summarized in Table 1.

The contaminant concentrations among the sand and fine fractions display trends opposite of that expected. The sand fraction is typically assumed to be relatively clean, and the fines to contain higher contaminant levels due to higher surface area and clay chemistry. Here, however, PAH and PCB concentrations in the sand exceed that of the fines, many by an order of magnitude. Most metal concentrations (arsenic, cadmium, chromium, copper, lead, mercury, selenium, manganese, molybdenum) were also higher in the sand than in the fines, but within the same order of magnitude. During wet sieving, an oily film was noted to settle on top of the sieved sand. It was thought that much of the contamination could be associated with this film, or with a coarse organic fraction. To evaluate this, the correlation coefficient was calculated for oil and grease and TOC concentrations versus PAH, PCB and metal concentrations. The resulting values indicate a strong linear relationship between oil and grease and $\mathrm{PAH}$ 
concentrations, and a moderate relationship between oil and grease and PCBs and metals concentrations (Figures 2, 3, and 4), with the exception of selenium and manganese, which evidenced a strong linear relationship. PAH versus PCB concentrations were quite strongly linear. The correlation coefficient for TOC versus $\mathrm{PAH}, \mathrm{PCBs}$, and metals indicates a moderate to weak linear relationship. Note that this does not imply that there is not a strong relationship, simply the absence of a strong linear relationship.

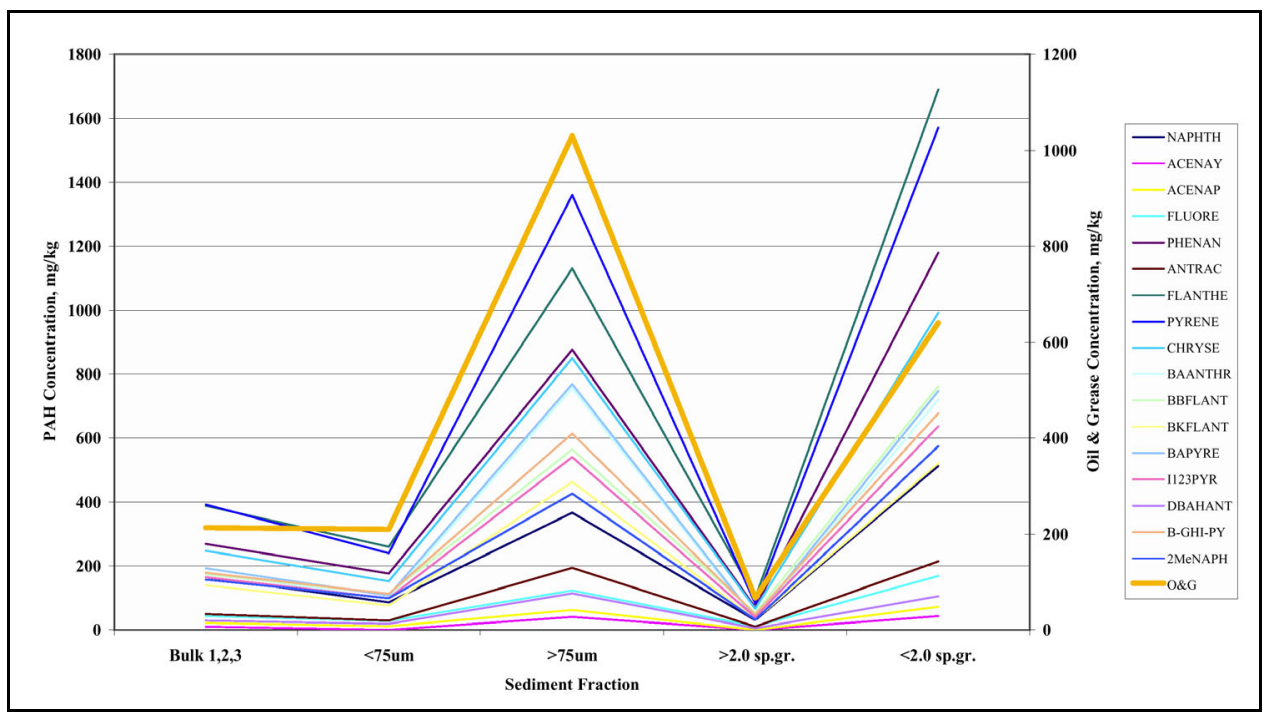

Figure 2. $\mathrm{PAH}$ versus oil and grease concentrations, Cell 5 material

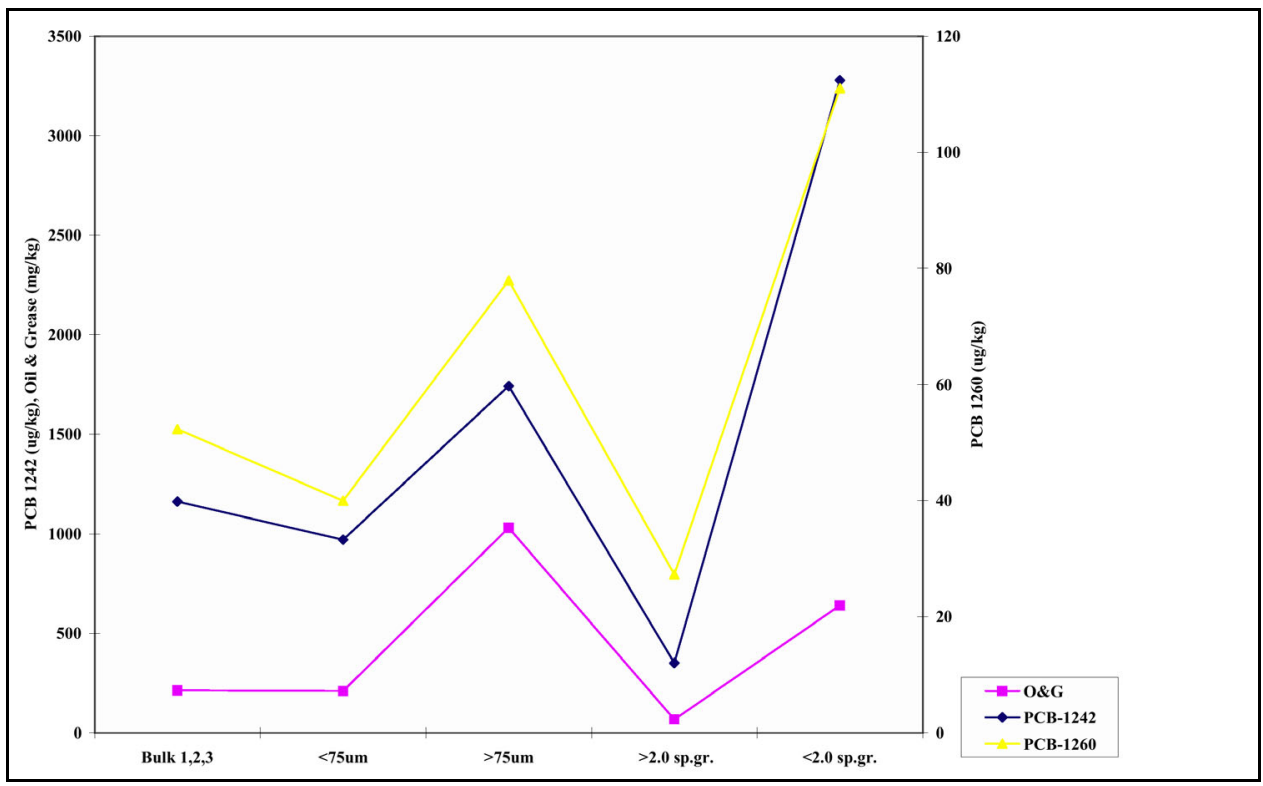

Figure 3. PCB versus oil and grease concentrations, Cell 5 material 


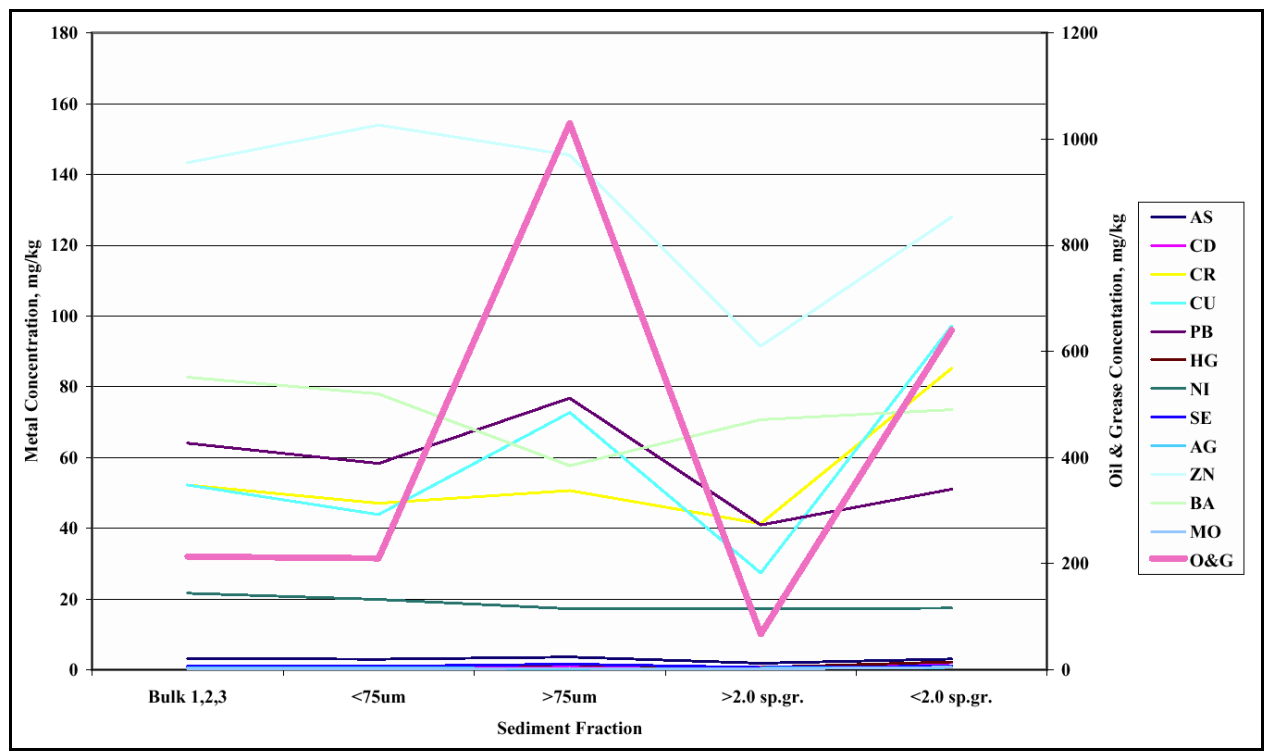

Figure 4. Metals versus oil and grease concentrations, Cell 5 material

The contaminant differences between the mineral and organic fractions were as expected, revealing order of magnitude greater PAH and PCB concentrations in the organic fraction. Metals were not as clearly distributed. Although higher concentrations of metals were present in the organic fraction, they were at the same order of magnitude as in the mineral fraction. Iron was an exception to this, being an order of magnitude higher in the mineral fraction than in the organic fraction. On average, metal concentrations were twice as high in the organic as in the mineral fraction (excluding iron), and PAHs and PCBs in the organic fraction averaged 18 and 7 times, respectively, that of the mineral fraction.

\section{Cell 4 characterization and bench-scale testing}

Particle size analysis. Samples C4P2, C4P4, and C4P6 were analyzed on the Coulter particle size analyzer to verify that a significant sand fraction was present. Percent greater than $75 \mu \mathrm{m}$ was approximately 40, 54, and 62 percent, respectively (by volume). Coulter analysis of the homogenized C4B samples indicated approximately 32.8 percent $>75 \mu \mathrm{m}$. The samples taken from along the inner radius $\mathrm{C} 4 \mathrm{~S} 1-3$ were also analyzed on the Coulter, with the volume percent less than $75 \mu \mathrm{m}$ ranging from 96.5 to 99.6 percent, indicating that particular area would not be a good candidate for sand recovery. Output from the Coulter for the C4B samples is presented in Appendix A. Particle size analysis results are given in Table 3. 


\begin{tabular}{|l|l|l|l|l||}
\hline \multicolumn{5}{|l|}{$\begin{array}{l}\text { Table } 3 \\
\text { Particle Size Analysis of Green Bay Cell 4 Samples }\end{array}$} \\
\hline \hline Volume, \% & C4P2 & C4P4 & C4P6 & C4B \\
\hline$<5 \mu \mathrm{m}$ & 15 & 13 & 10 & 20 \\
\hline$<75 \mu \mathrm{m}$ & 60 & 46 & 38 & 67.2 \\
\hline$>75 \mu \mathrm{m}$ & 40 & 54 & 62 & 32.8 \\
\hline
\end{tabular}

Bulk sediment chemistry. The $\mathrm{C} 4 \mathrm{~B} 1, \mathrm{C} 4 \mathrm{~B} 2$, and $\mathrm{C} 4 \mathrm{~B} 3$ samples were homogenized, and two samples were then taken for bulk chemical analysis. The average concentrations for the composite are reported in Table 4. The analysis revealed the existence of some PAHs and metals, and concentrations of 3,755 and $39 \mu \mathrm{g} / \mathrm{kg}$, respectively, for PCB 1242 and PCB 1260.

Water content analysis. The water content of the C4P2, C4P4, and C4P6 samples was measured in duplicate by oven drying. The water contents averaged 59,36 , and 27 percent, respectively, for the three samples.

Fractionation testing. Although a full size and density separation was desired on the Cell 4 material, due to time constraints the most important separation to evaluate initially was the sand/silt separation at $75 \mu \mathrm{m}$. This separation was achieved by wet sieving a subsample of the material through a $75-\mu \mathrm{m}$ sieve. The sand fraction was washed off the sieve, and the wash water was then drained off the sand. The sand sample was analyzed with the Coulter LS100 Particle Size Analyzer and was found to contain only 5.5 percent $<75 \mu \mathrm{m}$ and 1.1 percent $<5 \mu \mathrm{m}$ by volume, indicating a relatively clean separation. Half the fines slurry was flocculated using Hychem, Inc., CP626 cationic polymer. Two (duplicate) samples from both the dewatered sand and flocculated fines (silt/clay) samples were analyzed for chemical constituents as summarized in Table 4. The other half of the fines fraction was reserved for further fractionation testing. The unflocculated silt and clay fractions were separated using a 50-mm (2-in.) hydrocyclone and the fractions analyzed for PCBs and indicator analytes. The silt and clay fractions were analyzed on the Coulter to evaluate effectiveness of the hydrocyclone separation. Approximately 5.7 percent of the silt fraction was greater than $75 \mu \mathrm{m}$, and approximately 14 percent less than $3 \mu \mathrm{m}$. The presence of particles greater than $75 \mu \mathrm{m}$ in the silt fraction can be attributed to oblong particles that pass through the \#200 sieve, and agglomeration of particles, which the Coulter may read as a single, larger particle. The clay fraction was less clean, with a mean particle size of $15.24 \mu \mathrm{m}$, and a median particle size of $6.39 \mu \mathrm{m}$. Approximately 90 percent of the clay fraction was less than $36 \mu \mathrm{m}$, and 50 percent less than $6.4 \mu \mathrm{m}$. Only 25 percent was less than $2.7 \mu \mathrm{m}$. The silt and clay fractions were also subsequently analyzed for chemical constituents (Table 4).

Unlike the Cell 5 analysis, the Cell 4 data follow the expected trends, with greater concentrations of the contaminants associated with the fines than with the sand. Concentrations of metals in the silt/clay fraction are almost all one to two orders of magnitude higher than in the sand. PCBs are an order of magnitude higher in the silt/clay fraction than in the sand. Differences in concentrations 


\begin{tabular}{|c|c|c|c|c|c|}
\hline \multicolumn{6}{|c|}{$\begin{array}{l}\text { Table } 4 \\
\text { Chemical Analysis of Cell } 4 \text { Bulk and Fractionated Sediment } \\
\text { Samples }\end{array}$} \\
\hline \multirow[b]{2}{*}{ Analyte } & \multicolumn{4}{|c|}{ Size Fractions } & \multirow[b]{2}{*}{$\begin{array}{l}\text { Bulk Sediment } \\
\text { Avg. Conc. }\end{array}$} \\
\hline & $\begin{array}{l}\text { Sand } \\
(>75 \mu \mathrm{m}) \\
\text { Avg. Conc. }\end{array}$ & $\begin{array}{l}\text { Silt/Clay } \\
(<75 \mu \mathrm{m}) \\
\text { Avg. Conc. }\end{array}$ & $\begin{array}{l}\text { Silt } \\
(\approx 5 \mu \mathrm{m}-75 \mu \mathrm{m}) \\
\text { Conc. }\end{array}$ & $\begin{array}{l}\text { Clay } \\
(<5 \mu \mathrm{m}) \\
\text { Avg. Conc. }\end{array}$ & \\
\hline \multicolumn{6}{|c|}{ Indicator Analytes } \\
\hline $\mathrm{TOC}, \mathrm{mg} / \mathrm{kg}$ & 1435 & 21100 & 9180 & 78900 & 27300 \\
\hline O\&G, mg/kg & 43 & 475 & 110 & 320 & 220 \\
\hline $\mathrm{TRPH}, \mathrm{mg} / \mathrm{kg}$ & $10.5 \mathrm{~J}^{1}$ & 270 & 46 & 180 & 185 \\
\hline TVS, $\%$ & & & & & $<4 \%$ \\
\hline \multicolumn{6}{|c|}{ Metals, $\mathrm{mg} / \mathrm{kg}$} \\
\hline AS & 0.45 & 5.05 & 2 & 6.85 & 2.2 \\
\hline$C D$ & 0.04 & 1.355 & 0.32 & 2.29 & 0.6045 \\
\hline $\mathrm{CR}$ & 3.05 & 79.95 & 15.1 & 134 & 29.8 \\
\hline $\mathrm{CU}$ & 10.05 & 75.25 & 21.2 & 113 & 32.8 \\
\hline PB & 5.6 & 101.2 & 242 & 193.5 & 43.7 \\
\hline HG & 0.02 & 3.45 & 0.363 & 2.85 & 1.085 \\
\hline $\mathrm{NI}$ & 2.2 & 27.1 & 7 & 36.9 & 10.8 \\
\hline SE & $<0.200$ & 1.1 & 0.3 & 1.3 & 0.4995 \\
\hline$A G$ & 0.4 & 0.8995 & 0.4 & 1.6 & 0.4995 \\
\hline ZN & 13.5 & 148.555 & 320 & 681 & 76.1 \\
\hline BA & 4.6 & 104.5 & 27.5 & 183 & 42.85 \\
\hline FE & & & 10500 & 30600 & 3822.4 \\
\hline MN & 44.25 & 325.5 & 174 & 321 & 140 \\
\hline $\mathrm{MO}$ & $<0.100$ & 0.849 & 0.5 & 1 & 0.3495 \\
\hline \multicolumn{6}{|c|}{ PCBs, $\mu \mathrm{g} / \mathrm{kg}$} \\
\hline PCB-1016 & $<10.3$ & $<38.9$ & $<11.2$ & $<40.5$ & $<12.7$ \\
\hline PCB-1221 & $<10.3$ & $<38.9$ & $<11.2$ & $<40.5$ & $<12.7$ \\
\hline PCB-1232 & $<10.3$ & $<38.9$ & $<11.2$ & $<40.5$ & $<12.7$ \\
\hline PCB-1242 & 444 & 5927.5 & 1950 & 7595 & 3754.5 \\
\hline PCB-1248 & $<10.3$ & $<38.9$ & $<11.2$ & $<40.5$ & $<12.7$ \\
\hline PCB-1254 & $<10.3$ & $<38.9$ & $<11.2$ & $<40.5$ & $<12.7$ \\
\hline PCB-1260 & 21.4 & 317.5 & 18.2 & 238 & 39 \\
\hline \multicolumn{6}{|c|}{$\mathrm{PAHs}, \mu \mathrm{g} / \mathbf{k g}$} \\
\hline NAPHTH & $\star^{2}$ & * & * & * & 123.5 \\
\hline ACENAY & * & * & * & * & 14.2 \\
\hline ACENAP & * & * & * & * & 41.25 \\
\hline FLUORE & * & * & * & * & 53.4 \\
\hline \multicolumn{6}{|r|}{ (Continued) } \\
\hline $\begin{array}{l}1 \text { Indicates estir } \\
2 * \text { Due to budg } \\
\text { thought to be o } \\
\text { given are there }\end{array}$ & $\begin{array}{l}\text { ted concentr } \\
\text { ary constrain } \\
\text { reatest conc } \\
\text { e based on }\end{array}$ & $\begin{array}{l}\text { for analyte } \\
\text { actionation } \mathrm{t} \\
\text { There was i } \\
\text { sis of only o }\end{array}$ & $\begin{array}{l}\text { is above MDL bu } \\
\text { gg was limited to } \mathrm{F} \\
\text { ficient silt sample } \\
\text { ample. }\end{array}$ & $\begin{array}{l}\text { ut below LRL. } \\
\text { PCBs and me } \\
\text { e for duplicate }\end{array}$ & $\begin{array}{l}\text { which were } \\
\text { lysis; results }\end{array}$ \\
\hline
\end{tabular}




\begin{tabular}{|c|c|c|c|c|c|}
\hline \multicolumn{6}{|c|}{ Table 4 (Concluded) } \\
\hline \multirow[b]{2}{*}{ Analyte } & \multicolumn{4}{|c|}{ Size Fractions } & \multirow[b]{2}{*}{$\begin{array}{l}\text { Bulk Sediment } \\
\text { Avg. Conc. }\end{array}$} \\
\hline & $\begin{array}{l}\text { Sand } \\
(>75 \mu \mathrm{m}) \\
\text { Avg. Conc. }\end{array}$ & $\begin{array}{l}\text { Silt/Clay } \\
(<75 \mu \mathrm{m}) \\
\text { Avg. Conc. }\end{array}$ & $\begin{array}{l}\text { Silt } \\
(\approx 5 \mu \mathrm{m}-75 \mu \mathrm{m}) \\
\text { Conc. }\end{array}$ & $\begin{array}{l}\text { Clay } \\
(<5 \mu \mathrm{m}) \\
\text { Avg. Conc. }\end{array}$ & \\
\hline \multicolumn{6}{|c|}{ PAHs, $\mu \mathrm{g} / \mathrm{kg}$ (Concluded) } \\
\hline PHENAN & * & * & * & * & 228.5 \\
\hline ANTRAC & * & * & * & * & 46.55 \\
\hline FLANTHE & * & * & * & * & 217 \\
\hline PYRENE & * & * & * & * & 263 \\
\hline CHRYSE & * & * & * & * & 148 \\
\hline BAANTHR & * & * & * & * & 125 \\
\hline BBFLANT & * & * & * & * & 85.1 \\
\hline BKFLANT & * & * & * & * & 73.4 \\
\hline BAPYRE & * & * & * & * & 117.5 \\
\hline I123PYR & * & * & * & * & 82 \\
\hline DBAHANT & * & * & * & * & 15.45 \\
\hline B-GHI-PY & * & * & * & * & 95.55 \\
\hline $2 \mathrm{MeNAPH}$ & * & * & * & * & 145.5 \\
\hline
\end{tabular}

between the silt fraction and the clay fraction are not as consistent, but concentrations in the clay fraction are higher for all analytes tested. TOC in the clay fraction is approximately 8.5 times that in the silt. Oil and grease, TRPH, PCB-1242, and PCB-1260 in the clay fraction are 2.9, 3.9, 3.9 and 26 times greater, respectively, than in the silt. Based on correlation coefficients, there is a strong positive correlation between metals concentrations and oil and grease and TRPH concentrations (Figure 5). Metals are moderately correlated to TOC concentration. There is also a moderate to strong positive correlation between PCBs, TRPH, and oil and grease (Figure 6) and PCBs and TOC (Figure 7).

\section{Test Candidate Unit}

A 1-day field demonstration was scheduled for 10 August 2000 at the Bayport CDF, Green Bay, WI. Equipment arrived onsite on Monday, 7 August 2000. Three full days were required to set up the system. This was not sufficient time to debug and troubleshoot, however; a cold start was made on the day of the demonstration. An electrical problem, unrelated to the separation unit, caused a minor delay. The system ran intermittently after that, with additional delays for clearing the jet pump and replacing or tightening clamps on water supply or slurry delivery hoses. The system was operated for approximately 5 hours, at which time sufficient material had been processed to assess the separation efficiency, and overall system characteristics and trouble points had been identified. 


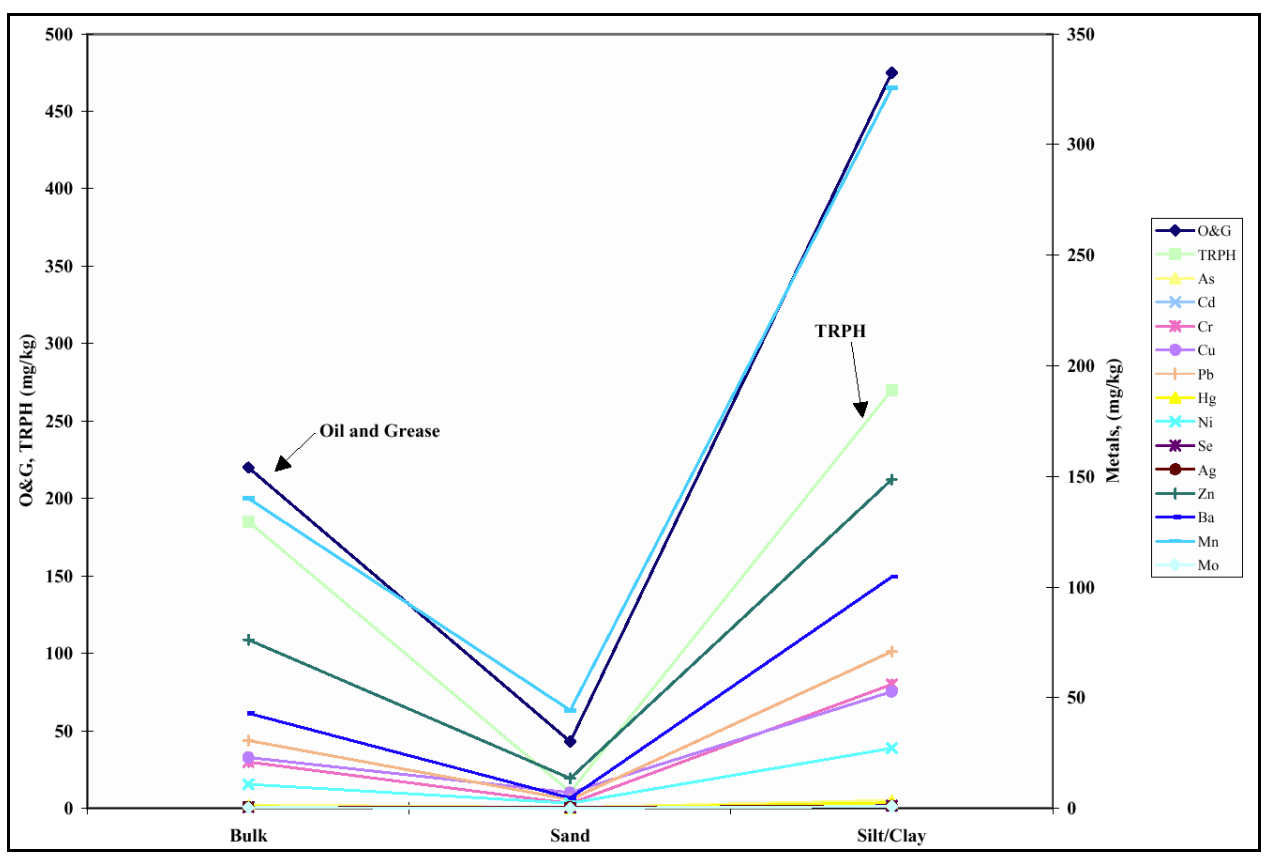

Figure 5. Metals versus TRPH and oil and grease concentrations, Cell 4 material

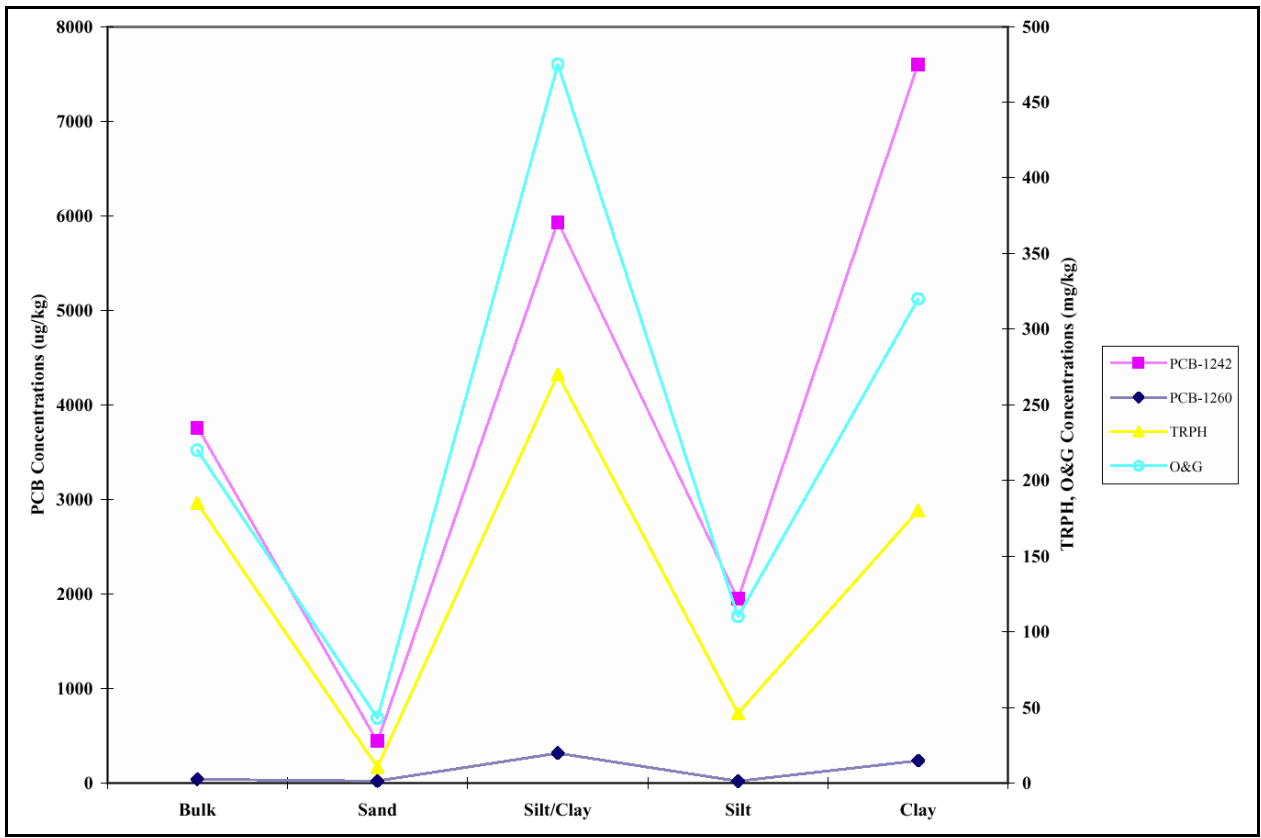

Figure 6. PCB versus TRPH and oil and grease concentrations, Cell 4 material 


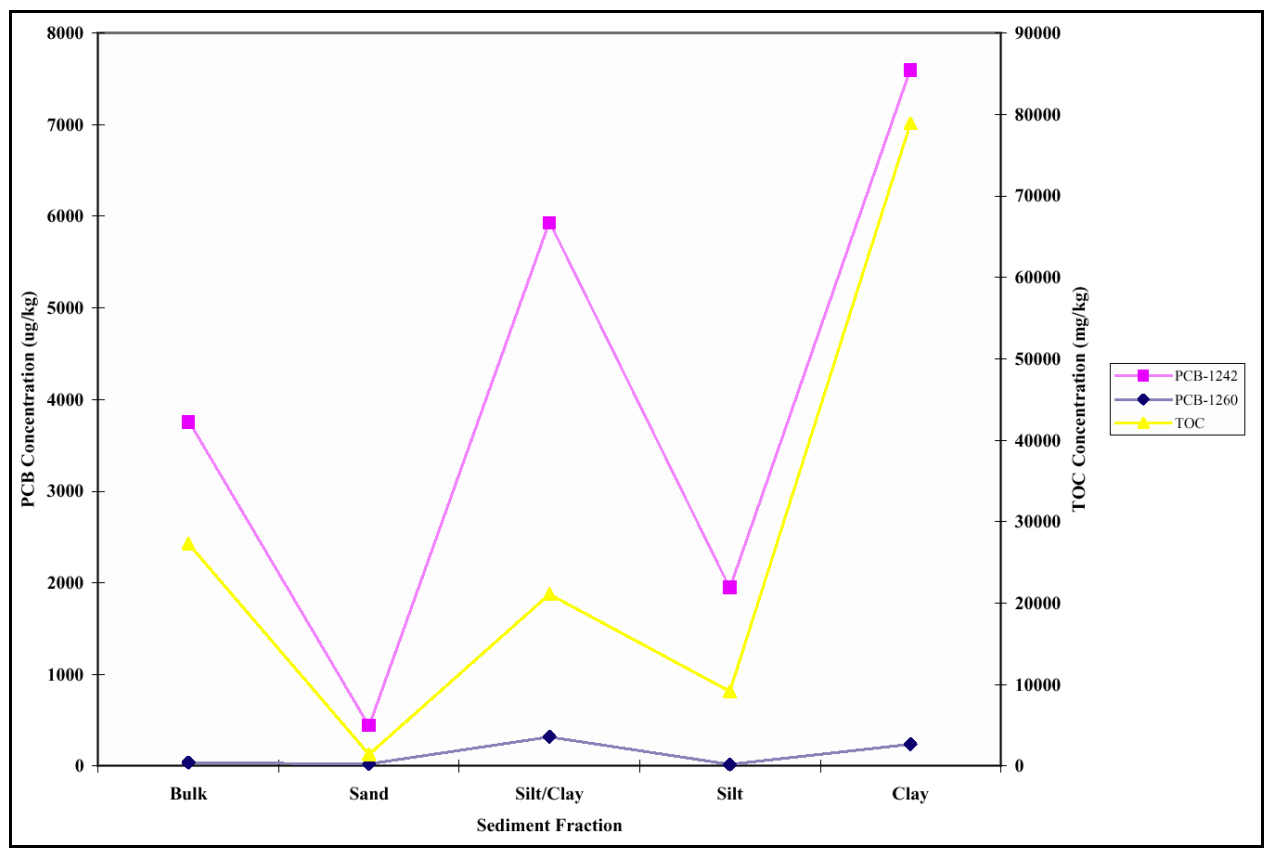

Figure 7. PCB versus TOC concentrations, Cell 4 material

\section{Site logistics}

The Cell 4 staging area was much farther from the freshwater source than the staging area originally selected for processing the Cell 5 material. Additionally, the Cell 4 staging area was much smaller than the original site, making onsite stockpiling of mechanically excavated material infeasible. It was therefore decided to excavate only a small amount of Cell 4 material for screening testing, and to excavate feed for the hydrocyclone using a modified jet pump. This was a particularly attractive alternative because of the potential benefits of small-scale hydraulic excavation or mechanical excavation (accessibility in unstable material, maneuverability around debris), and the added information that would result from a single effort. The principal disadvantage of this approach was that the process water had to be pumped approximately $300 \mathrm{~m}(1,000 \mathrm{ft})$ to the excavation point.

\section{Equipment}

Because of the distance between the staging area and the freshwater source, a larger water pump, transfer hoses, and generator were required than for the original staging area. Water pump, generator, and flexible hoses with quick couplings were available and obtained on a short-term rental basis. The MetPro mobile unit was as previously described in the section "Project Activities," consisting of a trailer, slurry pump, sump, and 0.6-m (24-in.) MDS (Figure 8). The eductor pump was fitted with an exterior ring, providing water jets for horizontal excavation (Figure 9). A powerscreen was also rented for screening the mechanically excavated material (Figures 10 and 11). The unit consisted of a grizzly, hopper with shredder, conveyer and shaking screen, equipped with a 


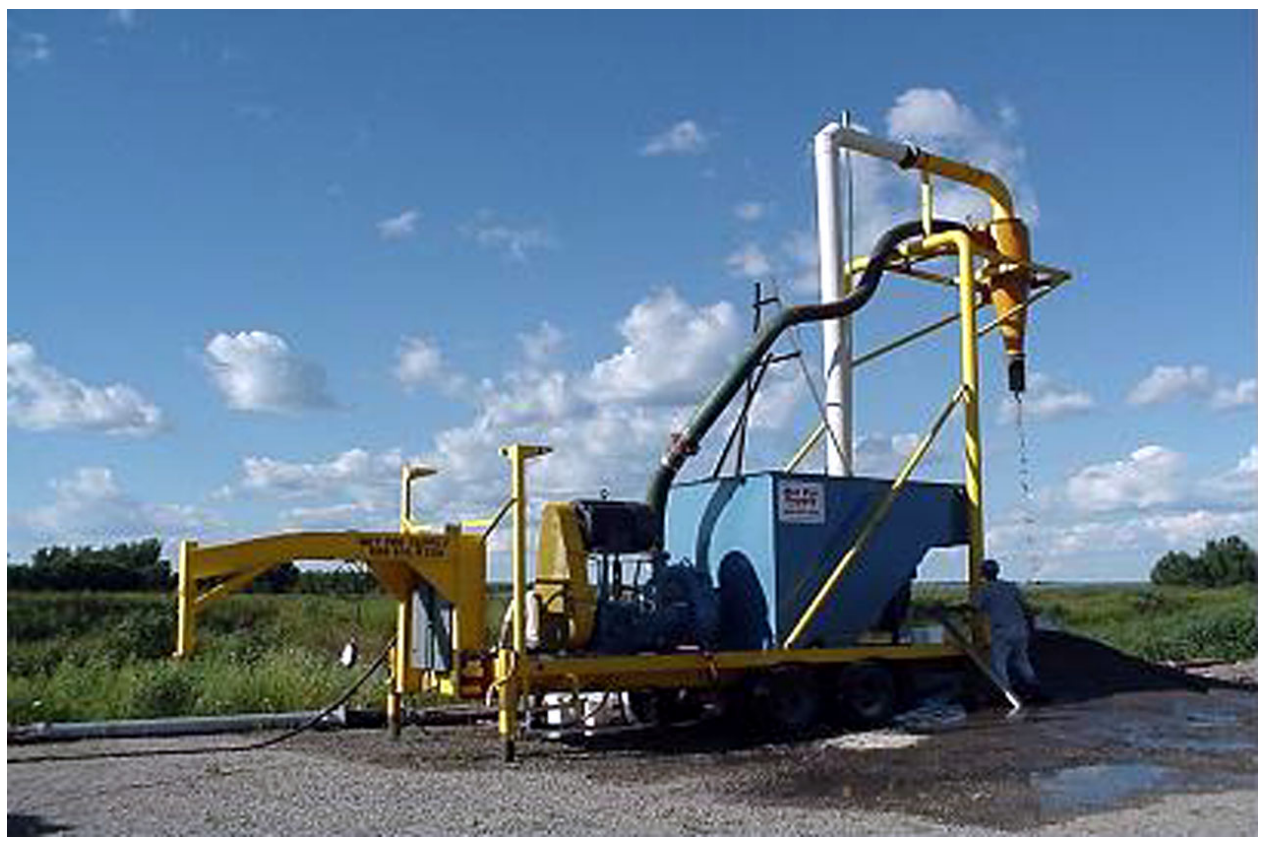

Figure 8. MetPro mobile MDS unit

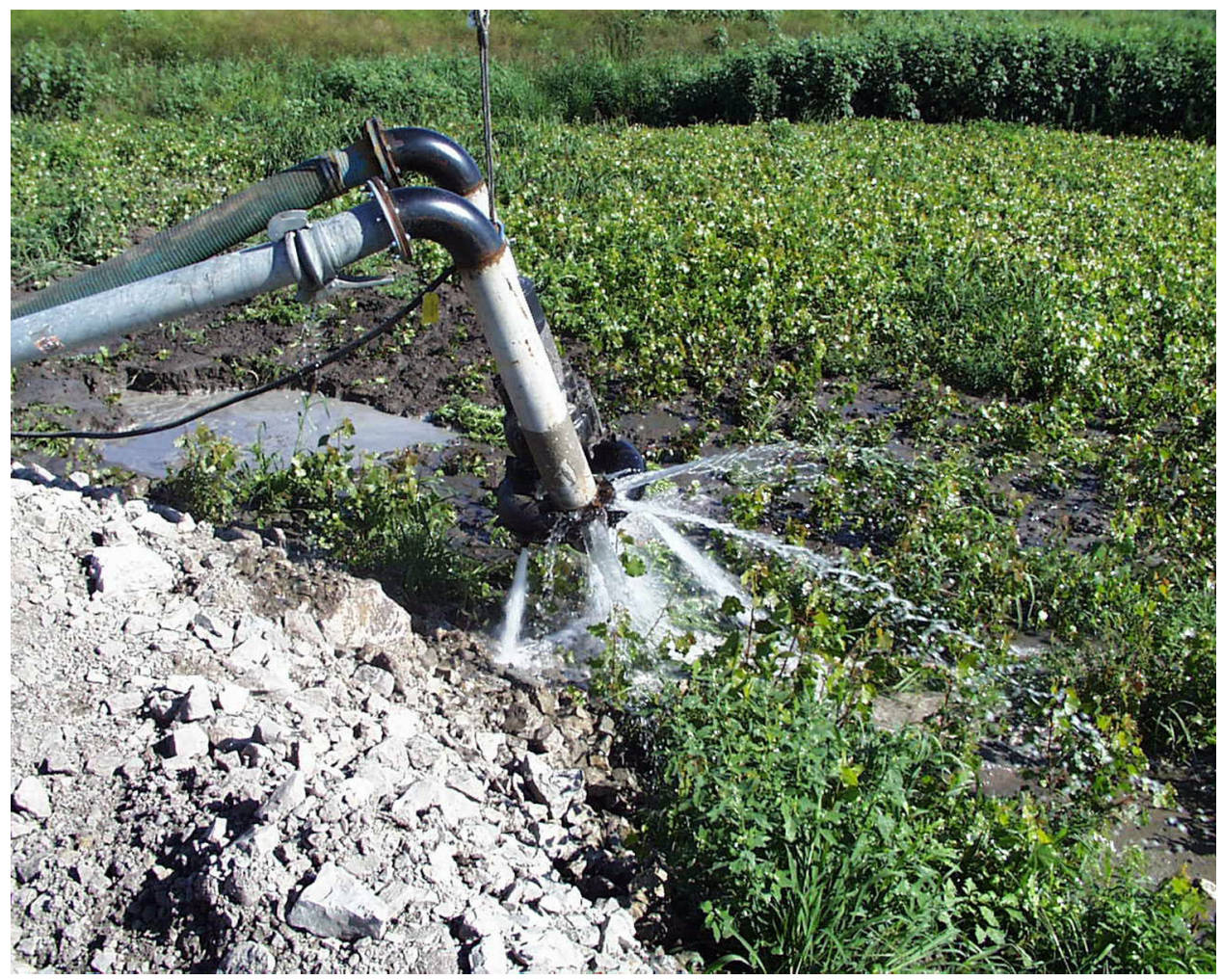

Figure 9. Eductor pump 


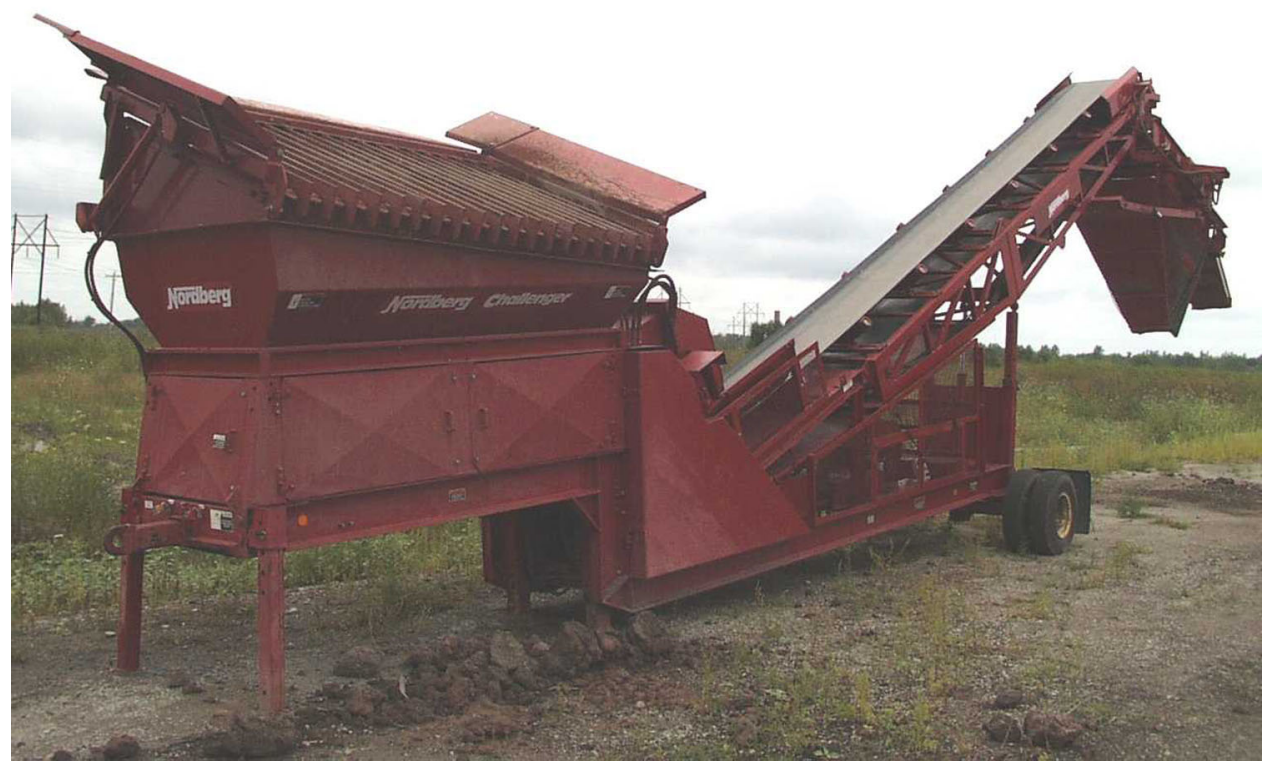

Figure 10. Powerscreen

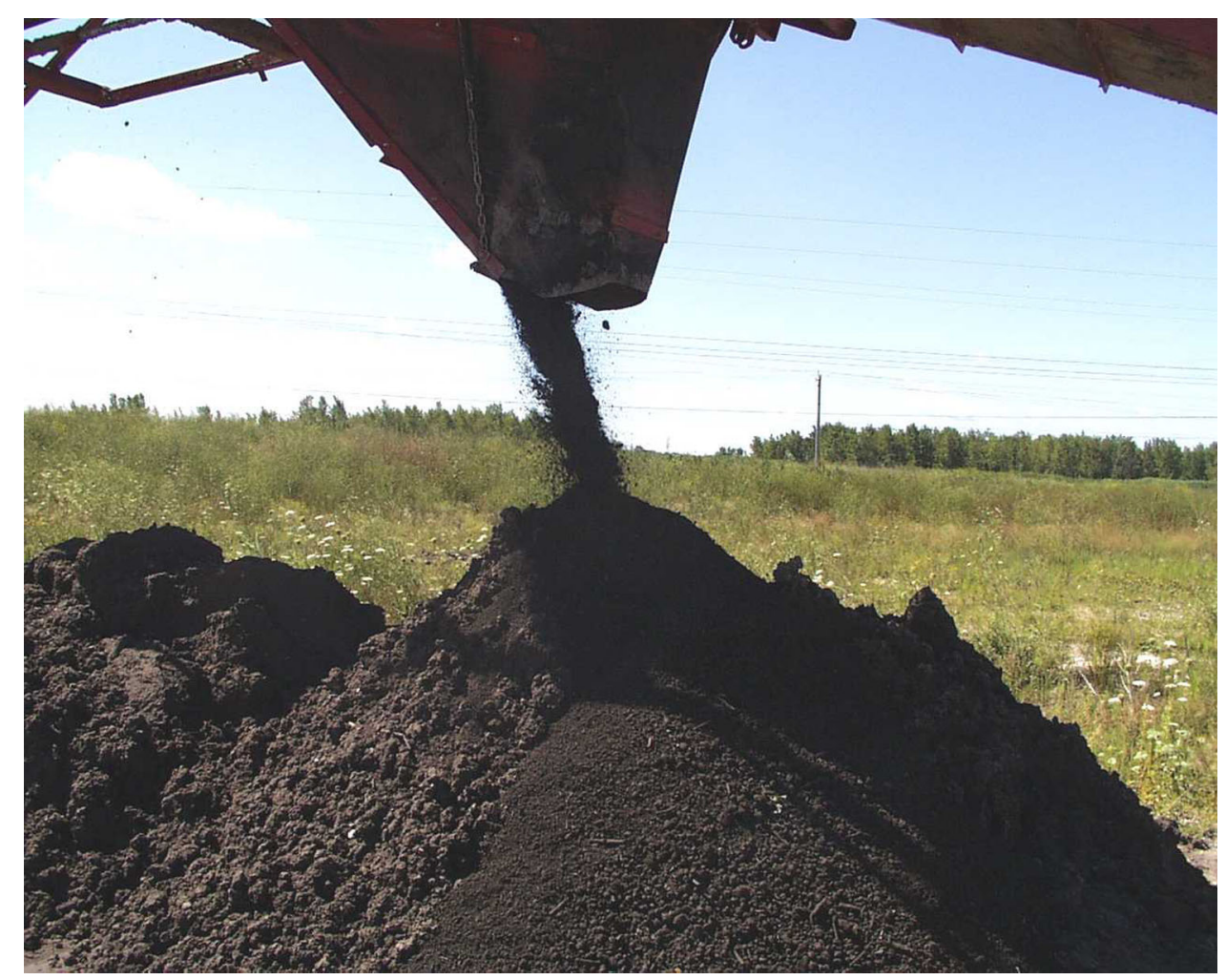

Figure 11. Screen undersize 
harp screen to enhance processing of clayey material and reduce plugging due to wet material.

\section{Field operation}

The generator and water pump performed well, and similar equipment should be readily available at most locations. The flexible hoses were not designed to operate at the optimum delivery pressure, however. Several failures of the coupling/hose attachment occurred, but once this problem was addressed, the hoses performed reasonably well with the pump discharge throttled back somewhat. Based on this experience, however, it is thought that suitable hoses should be purchased for future operations. The eductor pump, although somewhat crudely assembled for the purposes of demonstration, performed fairly effectively. Although the site was heavily vegetated, the vegetation did not prevent excavation of the sediment in situ. Some variability was noted in the feed percent solids. Although this does not appear to have adversely affected the separation achieved, the result is an inefficient utilization of available water supply; and under different circumstances, separation efficiency could be affected. The pump did plug with large woody debris on two or three occasions. This could be prevented with a coarse protective screen at the pump intake. Additionally, no water jets faced in the downward direction. Excavation was impeded when a large rock was encountered underneath the pump. The sump and cyclone performed as expected. There was one failure of a band coupling, and this is potentially a weak point in the system. This connection could be made more secure with permanent piping, rather than the flexible hoses used to deliver the slurry pump discharge to the hydrocyclone inlet.

The Powerscreen performed relatively well considering that the material being fed was much wetter than the equipment is designed to handle. Problems were encountered, however, in feeding the screen. Clay clods rolled off the grizzly, reporting with the oversize. Attempts to push this material through the grizzly were only partially successful and time-consuming. The shaking screen passed the moist, fine materials without any evident problem, but blinding did occur on the coarse upper screen, where 0.1- to 0.15-m (4- to 6-in.) chunks of asphalt collected and had to be manually scraped off. Although the results indicate that the Powerscreen may be useful to prepare a small amount of material for process testing, feeding a full-scale hydrocyclone operation in this manner is probably infeasible.

\section{Visitors}

The demonstration was scheduled for 10 August 2000. Notice of the demonstration was posted on the Detroit District Web site, and notification sent directly to regulators and environmental organizations in the region. Approximately 30 people attended the demonstration. Results of the demonstration were also presented to the Great Lakes Commission in October 2000 . 


\section{Process sampling}

Three 19-L (5-gal) samples were taken simultaneously from the feed slurry and overflow, and three 4-L (1-gal) samples were taken from the underflow at five different intervals during processing $(1400,1505,1525,1625$, and 1715 hours). Samples were captured and transported in new HDPE buckets. Of these, two from each sampling event were designated for particle size distribution and contaminant concentration analysis. The remainder of the samples were designated for particle size distribution only. The field sampling contractor was responsible for obtaining process samples and packaging and shipping them to ERDC. The overflow was sampled using a J-shaped diverter of polyvinyl chloride (PVC) pipe, which was passed through the overflow stream vertically to obtain a representative sample. The feed stream was sampled from a port welded onto the outlet from the slurry pump, where the slurry was expected to be turbulent and therefore well mixed. The line was purged for a few seconds prior to taking each sample. Underflow samples were captured directly from the cyclone underflow discharge. The volume of underflow samples was reduced from that specified in the Quality Assurance Project Plan ${ }^{1}$ due to the high solids content of the underflow; 4-L (1-gal) samples were sufficient for all proposed analysis. Samples designated for chemical analysis were placed in a cooler and packed in ice for shipment. Samples designated for particle size analysis only were not refrigerated. Chain-of-custody forms were completed.

A single 19-L (5-gal) sample of the process supply water was also taken to establish baseline concentrations. It was initially proposed to sample effluent at the pond discharge during and after processing to verify that no permit parameters were violated during processing. However, water levels in the pond were low enough that there was no discharge from the pond at the time of processing, and the process overflow was passed through a sand drainage bed prior to being returned to the pond, reducing suspended solids. Dissolved contaminant levels were therefore measured in the process overflow and compared to Freshwater Acute Federal water quality criteria (USEPA 1999a). Of the parameters measured in the overflow having criteria, none exceeded acute water quality criteria.

Upon arrival at ERDC, the samples were refrigerated, and samples designated for chemical analysis were quickly processed to meet specified holding times. The feed and overflow slurry samples designated for chemical analysis (two field duplicates per stream per sampling time) were sampled while being stirred to obtain representative samples of the slurry. They were then centrifuged, and both solids and supernatant collected for chemical analysis. Percent solids of the underflow samples was much higher, and subsamples were taken directly from the buckets for chemical and particle size analysis without centrifuging. Subsamples of all process solids were also taken for water content and particle size analysis. Due to the difficulty involved in obtaining a representative subsample from a slurry, slurry samples were allowed to settle for

\footnotetext{
${ }^{1}$ The QAPP describes the technical quality assurance/quality control for specific data collection, project objectives and organization, sampling design, analytical methods, data quality indicators, and data review (USEPA 1997, 1998).
} 
an extended period of time. The supernatant was then poured off, the supernatant and remaining wet solids weighed, and then water content of the wet solids determined by oven drying. In this manner, the initial solids content of the slurry could be calculated. The settled solids were analyzed on the Coulter particle size analyzer for particle size distribution.

\section{Results}

\section{Particle size analysis}

Results of the particle size data for samples taken from the feed and overflow samples while stirring versus samples taken from the settled slurries were different. Because the settled slurries were still relatively liquid but at a higher percent solids, it was possible to mix them thoroughly and avoid rapid settling of coarse particles, thus producing more representative samples of all size ranges in the solids. The feed and overflow particle size distributions reported in Table 5 are for the subsamples taken from the settled samples. The underflow contained less than 8 percent fines by volume. Depending upon the specific gravity of the particles, this can be converted to percent fines by weight. Because the Coulter counter measures particle volume only (void volume is not measured), percent sand by volume can be taken to be approximately equivalent to percent sand by mass, assuming the same specific gravity for all particles in the material.

\section{Percent moisture/percent solids}

Results of percent moisture $\left(\mathrm{W}_{\text {water }} / \mathrm{W}_{\text {total }}\right)$ and percent solids $\left(\mathrm{W}_{\text {solids }} / \mathrm{W}_{\text {total }}\right)$ for the process streams are summarized in Table 6 . The percent solids of the feed varied from 1.8 to 5.9 percent by weight. This is a relatively dilute feed stream. Although the separation efficiency is enhanced by a dilute feed stream, operational efficiency overall is lower than optimum. Percent solids of the underflow was quite high, ranging from 75.2 to 80.3 percent, reflecting the coarse nature of the underflow. Mean percent moisture of the underflow was approximately 22 percent, compared with approximately 98 percent for the feed and overflow process streams.

\section{Chemical analysis}

The results of the chemical analysis for each replicate at each sampling time were averaged for the three process streams, and are summarized in Table 7. For comparison, results of the bench-scale characterization for these fractions are given in parentheses. Qualitatively, the bench-scale testing appears to have given a relatively representative indication of the contaminant levels in the field-scale process streams. To evaluate whether the concentrations in the process and characterization fractions are essentially equivalent, the data were evaluated. Contaminants included arsenic, cadmium, chromium, copper, lead, mercury, nickel, selenium, silver, zinc, barium, PCB 1242, PCB 1260, TOC, oil and grease, and TRPH. One-half the detection limit was used for contaminant concentrations less than the detection limit. The Statistical Analysis System (SAS) release 8.1 was used to perform the data analysis (SAS Institute, Inc., 1989a, 1989b). The statistical procedures and assumptions are more fully 


\begin{tabular}{|c|c|c|c|}
\hline \multicolumn{4}{|c|}{$\begin{array}{l}\text { Table } 5 \\
\text { Particle Size Analysis of Streams from the Mobile Hydrocyclone } \\
\text { Demonstration }\end{array}$} \\
\hline Sample & $\begin{array}{l}\text { Sand } \\
\text { Volume \% > } 76.42 \mu \mathrm{m}\end{array}$ & \begin{tabular}{|l} 
Silt \\
Volume \% 5-76.42 $\mu \mathrm{m}$
\end{tabular} & $\begin{array}{l}\text { Clay } \\
\text { Volume } \%<5 \mu \mathrm{m}\end{array}$ \\
\hline \multicolumn{4}{|c|}{ Feed } \\
\hline F1400 & 26.2 & 55.6 & 18.2 \\
\hline F1505 & 23.4 & 59.1 & 17.5 \\
\hline F1525 & 33.5 & 49.6 & 16.9 \\
\hline F1625 & 26.9 & 55.2 & 17.9 \\
\hline F1715 & 30.4 & 52.5 & 17.1 \\
\hline Average & 28.1 & 54.4 & 17.5 \\
\hline \multicolumn{4}{|c|}{ Overflow } \\
\hline 01400 & 15.7 & 61.8 & 22.5 \\
\hline 01505 & 11.5 & 68.7 & 19.8 \\
\hline 01525 & 22.5 & 57.5 & 20 \\
\hline 01625 & 19.7 & 63.8 & 16.5 \\
\hline 01715 & 23.9 & 55.9 & 20.2 \\
\hline Average & 18.7 & 61.5 & 19.8 \\
\hline \multicolumn{4}{|c|}{ Underflow } \\
\hline U1400 & 91.36 & 7.02 & 1.62 \\
\hline U1505 & 92.12 & 6.56 & 1.32 \\
\hline U1525 & 90.23 & 8.05 & 1.72 \\
\hline U1625 & 92.52 & 6.08 & 1.4 \\
\hline U1715 & 94.31 & 4.43 & 1.26 \\
\hline Average & 92.11 & 6.43 & 1.46 \\
\hline
\end{tabular}

described in Appendix B. On the basis of the statistical analysis, the following generalizations regarding concentrations in the process streams and bench-scale samples, respectively, can be made:

a. $\quad$ Underflow $=$ sand

b. Overflow $=$ silt/clay for zinc, oil and grease, and TRPH

c. Overflow $<$ silt/clay for all other analytes except TOC

d. Overflow $>$ silt/clay for TOC

e. $\quad$ Feed $=$ bulk for all analytes except PCB 1260

f. $\quad$ Feed $>$ bulk for PCB 1260

The statistical power of the analysis for most analytes was less than 75 . The power was greater than 75 for comparison of nickel in underflow and sand, and for PCB 1242 in feed and bulk for the one-tailed tests. Power was also greater than 75 for comparison of nickel and PCB 1260 in underflow and sand and for comparison of arsenic, chromium, nickel, barium, PCB 1242, PCB 1260, oil and grease, and TRPH in feed and bulk for the two-tailed tests. 


\begin{tabular}{|c|c|c|}
\hline \multicolumn{3}{|c|}{$\begin{array}{l}\text { Table } 6 \\
\text { Percent Moisture and Percent Solids of Process Streams }\end{array}$} \\
\hline Sample & Percent Moisture & Percent Solids \\
\hline \multicolumn{3}{|c|}{ Feed } \\
\hline F1400 & 94.08 & 5.92 \\
\hline F1505 & 98.53 & 1.47 \\
\hline F1525 & 98.18 & 1.82 \\
\hline F1625 & 98.53 & 1.47 \\
\hline F1715 & 98.19 & 1.81 \\
\hline Average & 97.5 & 2.5 \\
\hline \multicolumn{3}{|c|}{ Overflow } \\
\hline 01400 & 96.94 & 3.06 \\
\hline 01505 & 98.80 & 1.20 \\
\hline 01525 & 98.88 & 1.12 \\
\hline 01625 & 99.09 & 0.91 \\
\hline 01715 & 98.66 & 1.34 \\
\hline Average & 98.5 & 1.5 \\
\hline \multicolumn{3}{|c|}{ Underflow } \\
\hline U1400-3 & 19.84 & 80.16 \\
\hline U1505-3 & 24.77 & 75.23 \\
\hline U1525-3 & 24.59 & 75.41 \\
\hline U1625-3 & 19.69 & 80.31 \\
\hline U1715-3 & 20.62 & 79.38 \\
\hline Average & 21.9 & 78.1 \\
\hline
\end{tabular}

From a practical standpoint, it appears that the bench-scale characterization will give predicted concentrations at least within the same order of magnitude as the field process. In some cases, it is quite representative of the contaminant distribution that will be achieved at full scale for this process. From a processing objective, the statistical analysis suggests that the quality of the underflow was higher than the quality of the sand produced in the bench-scale testing, which is a favorable outcome. In some cases this may be attributable to lower concentrations in the process feed, but for other constituents this is not the case. SAS output is presented in Appendix B.

With regard to the processing objectives, the contaminant concentrations in the underflow ranged from 2 percent to 39 percent of that in the feed. PCBs were reduced 95 percent (Arochlor 1242) and 92 percent (Arochlor 1260), from $2,714 \mu \mathrm{g} / \mathrm{kg}$ to $144 \mu \mathrm{g} / \mathrm{kg}$, and from $145 \mu \mathrm{g} / \mathrm{kg}$ to $11.9 \mu \mathrm{g} / \mathrm{kg}$, respectively. TOC, oil and grease, and TRPH were significantly reduced in the process underflow. Most metals concentrations were reduced by an order of magnitude in the underflow, selenium, silver, and molybdenum being the exceptions. Selenium was reduced by a factor of 2.6, silver by a factor of 2.6, and molybdenum by a factor of 7.8 .

Data validation sheets are included in Appendix C. Data were evaluated on the basis of representativeness, comparability, and completeness. 
Table 7

Process Streams Chemical Analysis

\begin{tabular}{|c|c|c|c|c|c|c|c|}
\hline \multirow[b]{2}{*}{ Analyte } & \multicolumn{3}{|c|}{ Process Solids } & \multicolumn{4}{|c|}{ Process Water } \\
\hline & Feed & Overflow & Underflow & Supply & Feed Supernatant & $\begin{array}{l}\text { Overflow } \\
\text { Supernatant }\end{array}$ & $\begin{array}{l}\text { Underflow } \\
\text { Supernatant }\end{array}$ \\
\hline \multicolumn{8}{|c|}{ Indicator Analytes } \\
\hline TOC (mg/kg) & $\begin{array}{l}26,500 \\
(27300)\end{array}$ & $\begin{array}{l}46,480 \\
(21100)\end{array}$ & $\begin{array}{l}1019 \\
(1435)\end{array}$ & & & & \\
\hline TVS (\%) & $<4(<4)$ & $<4$ & $<4$ & & & & \\
\hline O\&G (mg/kg) & $\begin{array}{l}332 \\
(220)\end{array}$ & $\begin{array}{l}435 \\
(475)\end{array}$ & \begin{tabular}{|l|}
16 \\
$(43)$
\end{tabular} & & & & \\
\hline TRPH (mg/kg) & \begin{tabular}{|l|}
259 \\
$(185)$
\end{tabular} & $\begin{array}{l}338 \\
(270)\end{array}$ & \begin{tabular}{|l|}
$<42.2$ \\
$(10.5 \mathrm{~J})$
\end{tabular} & & & & \\
\hline \multicolumn{8}{|c|}{ PCBs } \\
\hline $\begin{array}{l}\text { Arochlor } 1242 \\
(\mathrm{ppb})\end{array}$ & $\begin{array}{l}2713.8 \\
(3754.5)\end{array}$ & $\begin{array}{l}4037.9 \\
(5927.5)\end{array}$ & $\begin{array}{l}144.0 \\
(444)\end{array}$ & $<0.24$ & 0.27 & 0.21 & $\bar{N} / \mathrm{A}$ \\
\hline $\begin{array}{l}\text { Arochlor } 1260 \\
(\mathrm{ppb})\end{array}$ & $\begin{array}{l}145.0 \\
(39)\end{array}$ & $\begin{array}{l}109.9 \\
(317.5)\end{array}$ & $\begin{array}{l}11.9 \\
(21.4)\end{array}$ & $<0.24$ & $<0.24$ & $<0.26$ & $N / A$ \\
\hline \multicolumn{8}{|c|}{ Metals } \\
\hline As (ppm) & $2.805(2.2)$ & $\begin{array}{l}3.4 \\
(5.05)\end{array}$ & \begin{tabular}{|l|}
0.4883 \\
$(0.45)$
\end{tabular} & 0.005 & 0.0039 & 0.0041 & $N / A$ \\
\hline Cd (ppm) & $\begin{array}{l}0.5809 \\
(0.6045)\end{array}$ & $\begin{array}{l}0.82 \\
(1.355)\end{array}$ & $\begin{array}{l}0.05908 \\
(0.04)\end{array}$ & $<0.0002$ & $<0.0002$ & $<0.0002$ & $N / A$ \\
\hline $\mathrm{Cr}(\mathrm{ppm})$ & $\begin{array}{l}38.44 \\
(29.8)\end{array}$ & $\begin{array}{l}48.8 \\
(79.95)\end{array}$ & $\begin{array}{l}2.896 \\
(3.05)\end{array}$ & 0.006 & 0.0046 & 0.0055 & $N / A$ \\
\hline $\mathrm{Cu}(\mathrm{ppm})$ & $\begin{array}{l}37.81 \\
(32.8)\end{array}$ & $\begin{array}{l}50 \\
(75.25)\end{array}$ & $\begin{array}{l}3.386 \\
(10.05)\end{array}$ & 0.003 & 0.0025 & 0.0021 & $N / A$ \\
\hline $\mathrm{Pb}(\mathrm{ppm})$ & $\begin{array}{l}41.69 \\
(43.7)\end{array}$ & $\begin{array}{l}59.6 \\
(101.2)\end{array}$ & $\begin{array}{l}2.937 \\
(5.6)\end{array}$ & $<0.001$ & $<0.001$ & $<0.001$ & $N / A$ \\
\hline $\mathrm{Hg}(\mathrm{ppm})$ & $\begin{array}{l}0.8834 \\
(1.085)\end{array}$ & $\begin{array}{l}1.3 \\
(3.45)\end{array}$ & $\begin{array}{l}<0.040 \\
(0.02)\end{array}$ & $<0.00020$ & $<0.00020$ & $<0.00020$ & $N / A$ \\
\hline $\mathrm{Ni}$ (ppm) & \begin{tabular}{|l|}
15.718 \\
$(10.8)$
\end{tabular} & $\begin{array}{l}19.0 \\
(27.1)\end{array}$ & \begin{tabular}{|l|}
2.578 \\
$(2.2)$
\end{tabular} & 0.014 & 0.0096 & 0.0093 & $N / A$ \\
\hline Se (ppm) & $\begin{array}{l}0.5116 \\
(0.4995)\end{array}$ & $\begin{array}{l}0.65 \\
(1.1)\end{array}$ & $\begin{array}{l}0.2 \\
(<0.200)\end{array}$ & 0.002 & 0.002 & 0.002 & $N / A$ \\
\hline $\mathrm{Ag}(\mathrm{ppm})$ & \begin{tabular}{|l|}
0.3447 \\
$(0.4995)$
\end{tabular} & $\begin{array}{l}0.53 \\
(0.8995)\end{array}$ & \begin{tabular}{|l|}
0.1333 \\
$(0.4)$
\end{tabular} & $<0.001$ & $<0.001$ & $<0.001$ & $N / A$ \\
\hline Zn (ppm) & \begin{tabular}{|l|}
81.4 \\
$(76.1)$
\end{tabular} & $\begin{array}{l}116.9 \\
(148.55)\end{array}$ & $\begin{array}{l}5.431 \\
(13.5)\end{array}$ & 0.046 & 0.0428 & 0.0396 & $N / A$ \\
\hline $\mathrm{Ba}(\mathrm{ppm})$ & \begin{tabular}{|l|}
61.12 \\
$(42.85)$
\end{tabular} & \begin{tabular}{|l|}
79.4 \\
$(104.5)$
\end{tabular} & \begin{tabular}{|l}
5.5052 \\
$(4.6)$
\end{tabular} & 0.108 & 0.1828 & 0.1769 & $N / A$ \\
\hline $\mathrm{Fe}(\mathrm{ppm})$ & \begin{tabular}{|l}
14251 \\
$(3822.4)$
\end{tabular} & 18010 & 1879 & 0.08 & 0.1304 & 0.0703 & $N / A$ \\
\hline Mg (ppm) & 15200 & 17740 & $N / A$ & 75.6 & 76.85 & 78.19 & $N / A$ \\
\hline Mn (ppm) & $\begin{array}{l}275.2 \\
(140)\end{array}$ & $\begin{array}{l}366.2 \\
(325.5)\end{array}$ & $\begin{array}{l}47.71 \\
(44.25)\end{array}$ & 3.03 & 1.609 & 1.60 & $N / A$ \\
\hline Mo (ppm) & $\begin{array}{l}0.7798 \\
(0.3495)\end{array}$ & $\begin{array}{l}0.40 \\
(0.849)\end{array}$ & $\begin{array}{l}0.1 \\
(<0.100)\end{array}$ & $<0.001$ & 0.003 & 0.0033 & $N / A$ \\
\hline
\end{tabular}


Representativeness and comparability are qualitative criteria, and completeness is a quantitative criterion. Representativeness is a key concern during field sampling activities, and expresses the degree to which sample data accurately represent the site, specific matrices, and parameter variations at a sampling point. Representativeness is dependent on the proper design of the sampling program, proper selection of laboratory methods for the matrix under scrutiny, and stability of the laboratory methods. The representativeness criterion is best satisfied by making certain that the sampling locations, procedures, and quantities are selected based on the project objectives, and that suitable analytical procedures are utilized, preservation requirements are met, and holding times are not exceeded in the laboratory.

Comparability expresses the confidence with which one data set can be compared with another. The analysis of certified reference materials is used to provide data on comparability. The data obtained within this project will be comparable because all the standard operating procedures used in the determinations are based on methods with proven protocols and proven internal and external audit compliance relative to performance testing on certified reference material soils. All analyses of a single type will be conducted at the same laboratory. Completeness of the deliverable is measured for each set of data received by dividing the number of valid (passing quality assurance/quality control (QA/QC) requirements) measurements actually obtained by the number of measurements made. Each of the analytical parameters is evaluated separately in terms of precision, accuracy, and data acceptability. Precision pertains to the repeatability of the test, and is determined using a relative percent difference for duplicate samples and, for three or more replicate analysis, as a relative standard deviation or coefficient of variation. Most literature suggests that the goal for precision among field duplicates should be within 30 percent expressed as a relative percentage difference. Accuracy pertains to the closeness to the true value, and is evaluated using matrix spike recoveries expressed as a percent recovery. Completeness is then calculated on the basis of the number of samples meeting the established $\mathrm{QA} / \mathrm{QC}$ requirements, as previously described. Acceptable completeness for a data set has been set at 90 percent meeting $\mathrm{QA} / \mathrm{QC}$ requirements.

Completeness of the data was above 90 percent for all three data sets (Cells 4 and 5 characterization and field demonstration data). Some data were qualified due to minor problems. Corrective actions and data qualifications are detailed in the individual data validation sheets attached in Appendix C.

\section{Equipment Acquisition}

On the basis of the performance of the 0.6-m (24-in.) MDS, a 0.3-m (12-in.) MDS was purchased for laboratory and field-scale feasibility testing. The capacity of the $0.3-\mathrm{m}$ (12-in.) MDS is not sufficient for large-scale processing, but is better suited for feasibility testing because the volumes of process water required are more manageable, and the supporting equipment is correspondingly smaller and more widely available. A vibrating wet screen was also purchased for screening out oversize prior to the sump of the hydrocyclone, and fitted with 13-mm (1/2-in.) and 6-mm (1/4-in.) screens. Either dry or slurried material can 
be fed onto the screen. The screen was ordered with excess capacity so that it could also be used with full-scale processing operations. 


\section{Conclusions}

The principal objectives of the project were to evaluate the efficiency of the 0.6-m (24-in.) MDS in producing a sand fraction with fines and PCB concentrations sufficiently reduced to permit beneficial use, and to evaluate the correspondence of contaminant levels predicted by bench-scale testing versus field-scale operation. The target product (sand) specifications were less than 10 percent fines by mass and PCB concentrations less than $1 \mathrm{mg} / \mathrm{kg}$. The underflow fraction produced averaged over 92 percent sand, as measured by a Coulter counter, and $0.144 \mathrm{mg} / \mathrm{kg}$ PCB 1242 and $0.0119 \mathrm{mg} / \mathrm{kg}$ PCB 1260. Based on statistical analysis of the results, the contaminant concentrations predicted for the sand fraction by the bench-scale testing were essentially equivalent to that achieved in the field operation. This is particularly significant since the process feed concentration of PCB 1260 was statistically greater than the bulk sediment concentration for the bench-scale testing. This indicates a somewhat higher efficiency of PCB removal for the MDS compared with that of wet sieving of the material. This may be attributable to the presence of coarse organic particles, which would report with the sand on a wet sieve, but would report with the overflow of a hydrocyclone. This is supported by the higher TOC concentration measured in the process overflow compared with that of the silt/clay fraction of the bulk sediment used in bench-scale testing. Distribution of metals was somewhat more variable than for PCBs, but metals were reduced by an order of magnitude in the sand fraction, with the exception of selenium, silver, and molybdenum. Selenium, silver, and molybdenum were reduced by factors of 2.6 to 7.8. In the absence of specific criteria establishing acceptable levels of metal constituents, partitioning theory could be used to evaluate the magnitude of potential release of metals in the beneficial use environment. Predicted releases could then be compared with applicable water quality criteria and necessary dilutions estimated. 


\section{References}

Granat, M. A. (1998). "Jacksonville District hydrocyclone experience." Proceedings of the $11^{\text {th }}$ Annual National Conference on Beach Preservation Technology, Tallahassee, FL, February 4-6, 1998.

Olin-Estes, T. J. (2000). "Determining recovery potential of dredged material for beneficial use - Site characterization: Statistical approach," DOER Technical Notes Collection (ERDC TN-DOER-C15), U.S. Army Engineer Research and Development Center, Vicksburg, MS. www.wes.army.mil/el/dots/doer

Olin, T. J., and Bowman, D. W. (1996). "Soil washing potential at confined disposal facilities," U.S. Army Engineer Waterways Experiment Station, Vicksburg, MS.

Olin-Estes, T. J., and Palermo, M. R. (2000a). "Determining recovery potential of dredged material for beneficial use-Site characterization: Prescriptive approach," DOER Technical Notes Collection (ERDC TN-DOER-C14), U.S. Army Engineer Research and Development Center, Vicksburg, MS. www.wes.army.mil/el/dots/doer

. (2000b). "Determining recovery potential of dredged material for beneficial use-Soil separation concepts," DOER Technical Notes Collection (ERDC TN-DOER-C13), U.S. Army Engineer Research and Development Center,Vicksburg, MS. www.wes.army.mil/el/dots/doer

SAS Institute, Inc. (1989a). "SAS/STAT User's Guide, Version 6, Volume 1," 4th ed., Cary, NC.

. (1989b). "SAS/STAT User's Guide, Version 6, Volume 2," 4th ed., Cary, NC.

Snedecor, G. W., and Cochran, W. G. (1980). Statistical Methods, 7th ed., The Iowa State University Press, Ames, IA.

U.S. Environmental Protection Agency. (1986). "Test methods for evaluating solid waste physical and chemical methods," SW-846, 2d ed., National Technical Information Service, Springfield, VA (NTIS No. PB87-120291).

. (1994). "Pilot-scale demonstration of sediment washing for the treatment of Saginaw River sediments," EPA 905-R94-019, Assessment and Remediation of Contaminated Sediments Program, Great Lakes National Program Office, Chicago, IL. 
U.S. Environmental Protection Agency. (1997). "EPA requirements for Quality Assurance Project Plans for environmental data operations," EPA QA/R-5, Washington, DC. . (1998). "EPA guidance for Quality Assurance Project Plans," EPA/600/R-98/018, Washington, DC. . (1999a). "National Recommended Water Quality CriteriaCorrection,” EPA 822-Z-99-001, Office of Water.

. (1999b). "Physical separation (soil washing) for volume reduction of contaminated soils and sediments: Processes and equipment," EPA-905-R99-006, Great Lakes National Program Office, Chicago, IL. 


\section{Appendix A Coulter Counter Particle Size Analysis, Cell 4 Material}


US Waterways Experiment Station

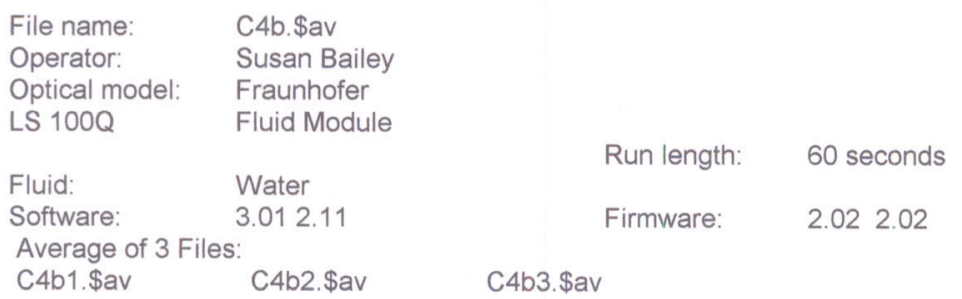

Differential Volume (Average) (2 S.D.)

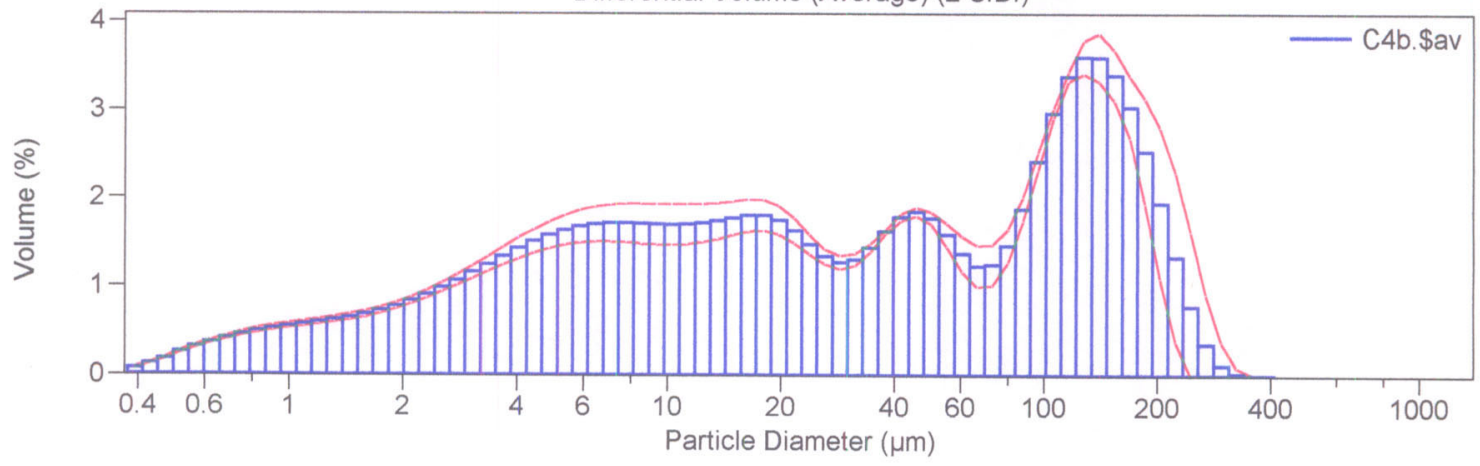

Volume Statistics (Arithmetic) C4b.\$av

Calculations from $0.375 \mu \mathrm{m}$ to $948.2 \mu \mathrm{m}$

\begin{tabular}{|c|c|c|c|c|c|}
\hline $\begin{array}{l}\text { Volume: } \\
\text { Mean: } \\
\text { Median: } \\
D(3,2) \text { : } \\
\text { Mode: }\end{array}$ & & $\begin{array}{l}100 \% \\
59.32 \mu \mathrm{m} \\
25.95 \mu \mathrm{m} \\
6.291 \mu \mathrm{m} \\
127.6 \mu \mathrm{m}\end{array}$ & $\begin{array}{l}\text { S.D. } \\
\text { C.V. }\end{array}$ & & $\begin{array}{l}65.88 \mu \mathrm{m} \\
111 \%\end{array}$ \\
\hline$\%<$ & $\begin{array}{l}10 \\
2.371\end{array}$ & $\begin{array}{l}25 \\
6.565\end{array}$ & $\begin{array}{l}50 \\
25.95\end{array}$ & $\begin{array}{l}75 \\
107.9\end{array}$ & $\begin{array}{l}90 \\
161.7\end{array}$ \\
\hline
\end{tabular}


US Waterways Experiment Station

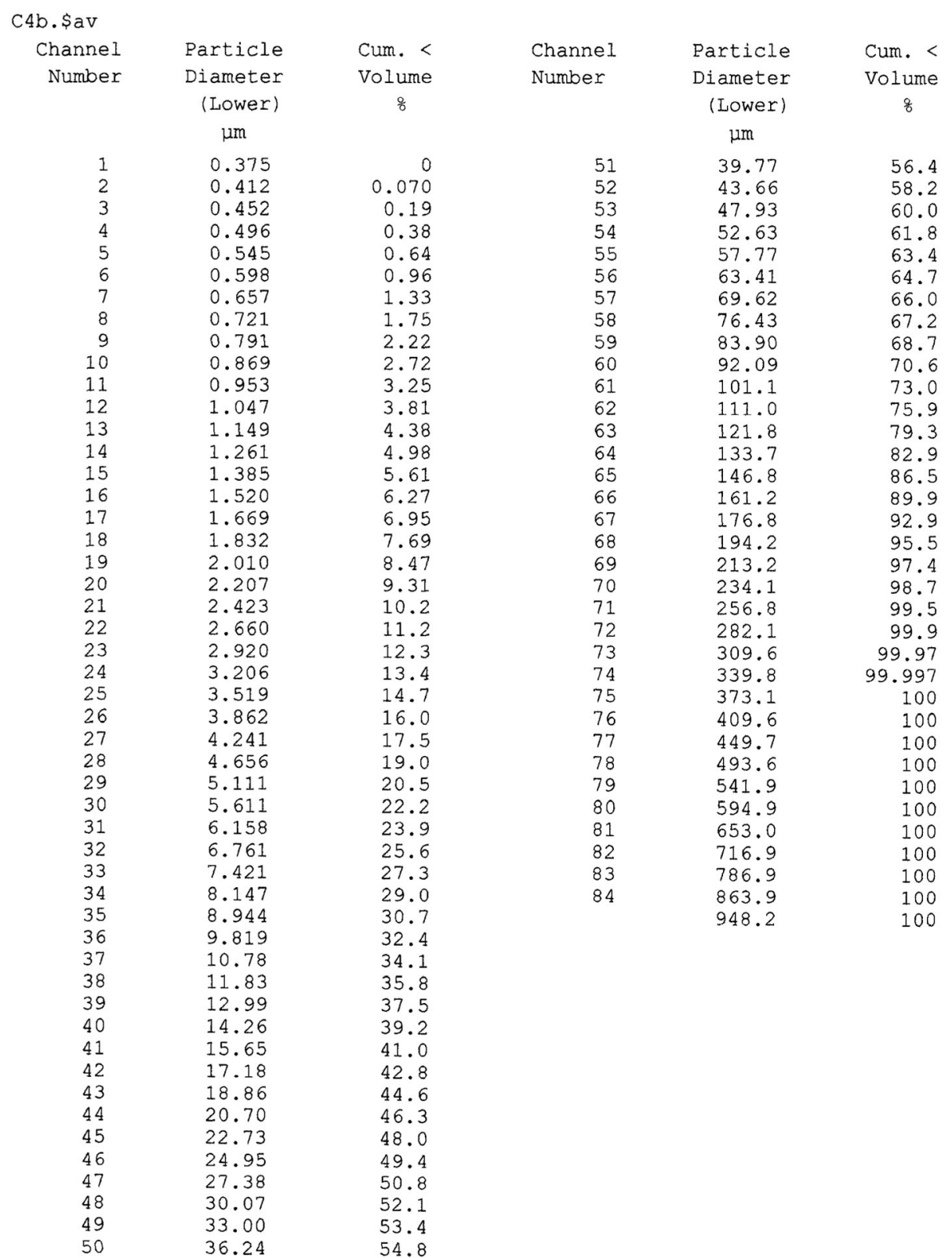




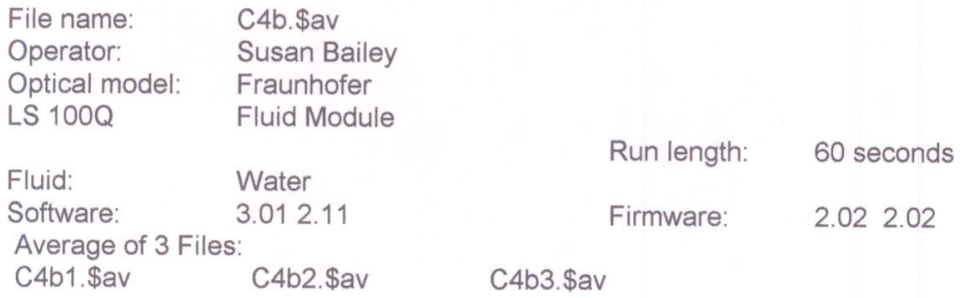

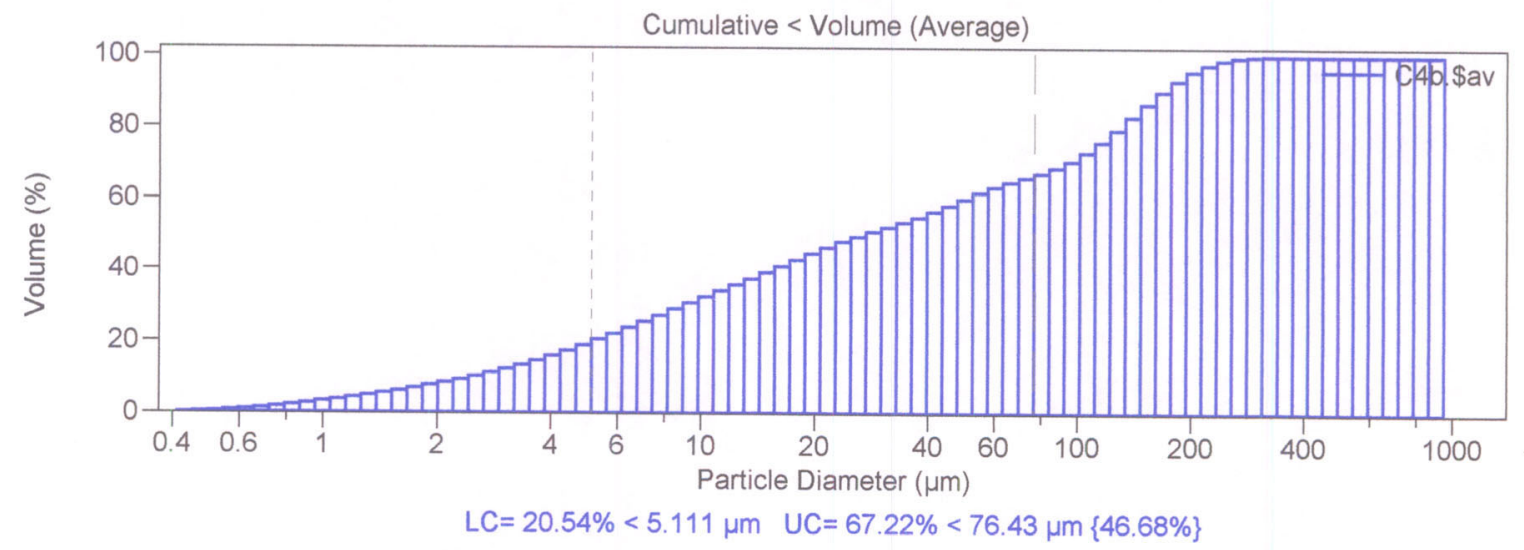

Volume Statistics (Arithmetic) C4b.\$av

Calculations from $5.111 \mu \mathrm{m}$ to $76.43 \mu \mathrm{m}$

\begin{tabular}{|c|c|c|c|c|c|}
\hline \multirow{5}{*}{$\begin{array}{l}\text { Volume: } \\
\text { Mean: } \\
\text { Median: } \\
D(3,2) \text { : } \\
\text { Mode: }\end{array}$} & & $46.7 \%$ & & & \\
\hline & & $25.13 \mu \mathrm{m}$ & S.D. & & $18.77 \mu \mathrm{m}$ \\
\hline & & $18.19 \mu \mathrm{m}$ & C.V. & & $74.7 \%$ \\
\hline & & $14.33 \mu \mathrm{m}$ & & & \\
\hline & & $45.75 \mu \mathrm{m}$ & & & \\
\hline $\begin{array}{l}\%< \\
\mu m\end{array}$ & $\begin{array}{l}10 \\
6.639\end{array}$ & $\begin{array}{l}25 \\
9.729\end{array}$ & $\begin{array}{l}50 \\
18.19\end{array}$ & $\begin{array}{l}75 \\
37.89\end{array}$ & $\begin{array}{l}90 \\
55.08\end{array}$ \\
\hline
\end{tabular}




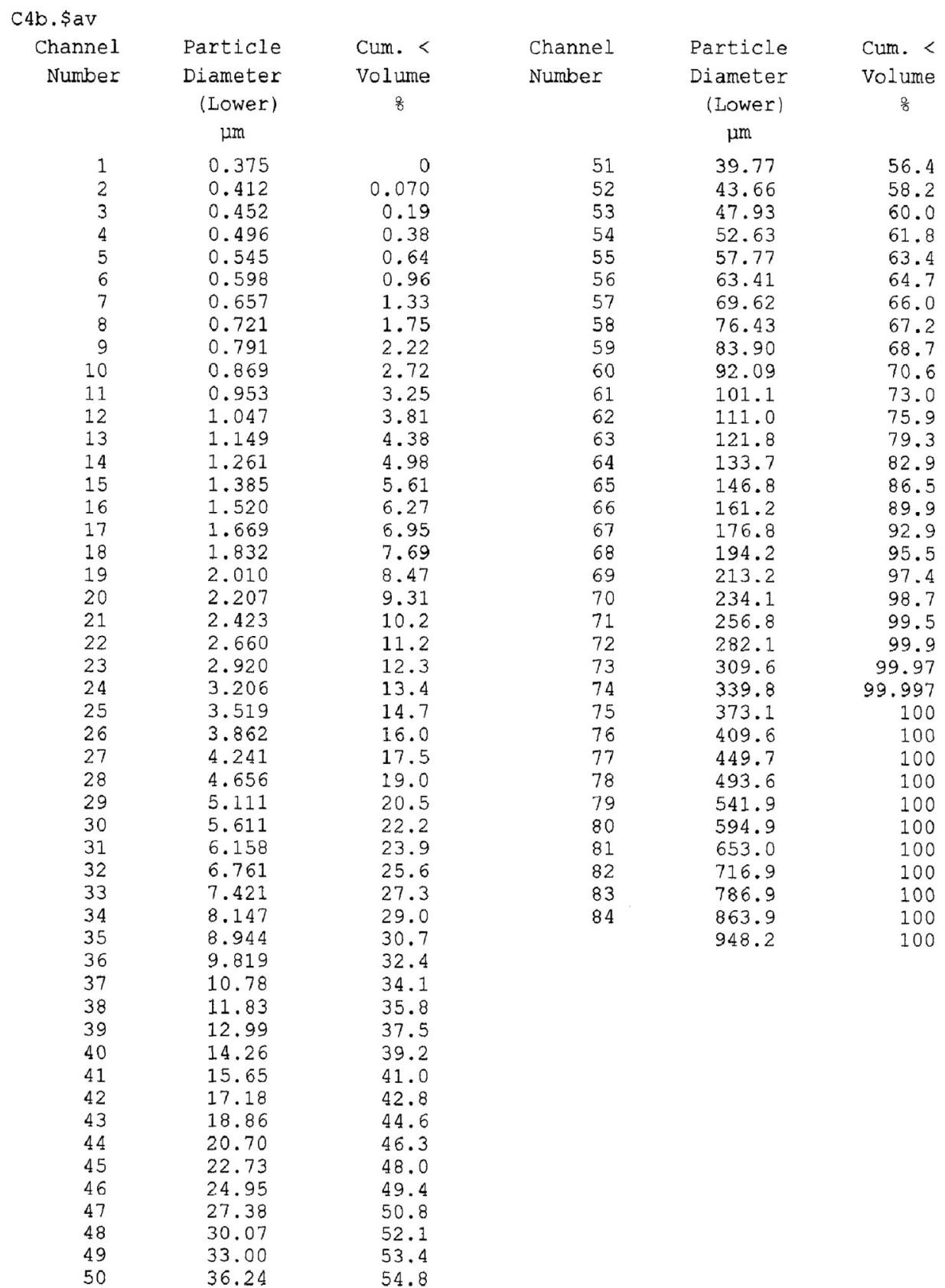




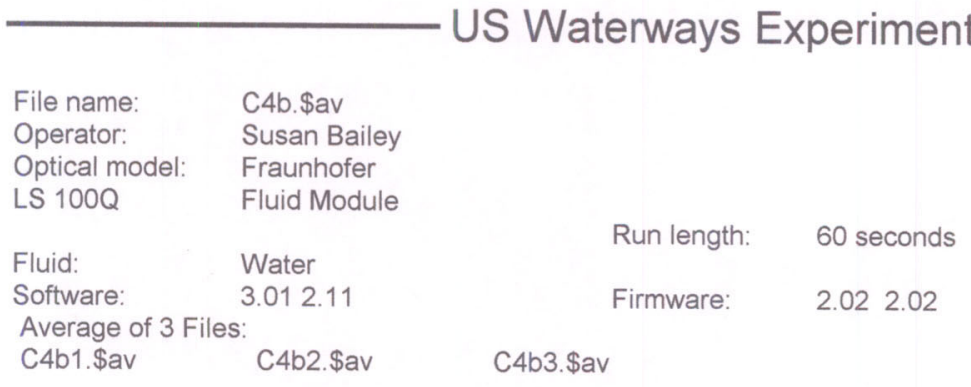

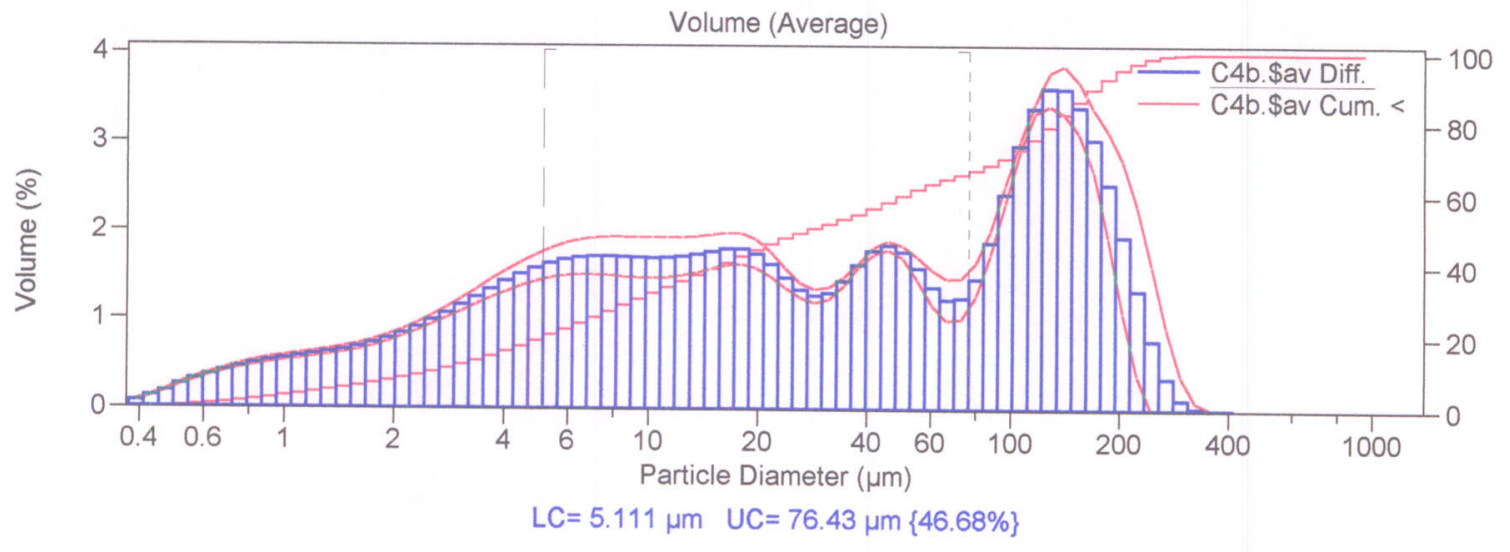




\section{Appendix B Statistical Analysis of Results}




\section{Statistical Procedures, Assumptions and Analysis}

Step (A). Evaluate the equality of variance assumption using the folded form of the F statistic (Snedecor and Cochran 1980). ${ }^{1}$ The null hypothesis is that the variance of group 1 is equal to the group 2 variance. The alternative hypothesis is that the variance of group 1 is not equal to the group 2 variance. These results are shown in Tables B3, B6, and B9. If probability $\mathrm{Pr}>\mathrm{F}$ is less than 0.05 , the null hypothesis was rejected.

Step (B). If the equality of variance hypothesis is not rejected, the test statistic was calculated using a pooled estimate of the variance. If the equality of variance hypothesis is rejected, a test statistic that assumes unequal population variances was utilized (Snedecor and Cochran 1980). These results are shown in Tables B2, B5, and B8. The respective hypotheses were expressed as HO: $\mu$ Feed $\leq \mu$ Bulk and HA: $\mu$ Feed $>\mu$ Bulk; HO: $\mu$ Underflow $\leq \mu$ Sand and HA: $\mu$ Underflow $>\mu$ Sand; HO: $\mu$ Overflow $\leq \mu$ Silt/Clay and HA: $\mu$ Overflow $>$ $\mu$ Silt/Clay. The one-tailed t-test was conducted at $\alpha=0.05$. For a one-tailed t-test halve the Prov $>|\mathrm{T}|$ value. Reject the null hypothesis if half the Prob $>|\mathrm{T}|$ is less than 0.05 .

From the underflow and sand data one would conclude that the underflow mean concentrations are less than or equal to the sand mean concentrations (Table B2). For the current experimental design, the mean comparison for nickel was the only comparison with a power greater than 0.75 . From the overflow and silt/clay data one would conclude that the arsenic, cadmium, chromium, copper, lead, mercury, nickel, selenium, silver, zinc, barium, PCB 1242, PCB 1260, oil and grease, and TRPH overflow mean concentrations are less than or equal to the silt/clay mean concentrations and the TOC overflow mean concentration is greater than the silt/clay mean concentration (Table B5). For the current experimental design, the TOC and TRPH comparisons were the only comparisons with a power greater than 0.75 . From the feed and bulk data one would conclude that the arsenic, cadmium, chromium, copper, lead, mercury, nickel, selenium, silver, zinc, barium, PCB 1242, TOC, oil and grease, and TRPH feed mean concentrations are less than or equal to the bulk mean concentrations and the PCB 1260 feed mean concentration is greater than the bulk mean concentration (Table B8). For the current experimental design, the PCB 1242 comparison was the only comparison with a power greater than 0.75 .

An alternate way to write the respective hypotheses was $\mathrm{HO}: \mu$ Feed $=\mu \mathrm{Bulk}$ and HA: $\mu$ Feed $\neq \mu$ Bulk; HO: $\mu$ Underflow $=\mu$ Sand and HA: $\mu$ Underflow $\neq$ $\mu$ Sand; HO: $\mu$ Overflow $=\mu$ Silt $/$ Clay and HA: $\mu$ Overflow $\neq \mu$ Silt $/$ Clay. Reject the null hypothesis if the Prob $>|\mathrm{T}|$ is less than 0.05 .

From the underflow and sand data one would conclude that the underflow mean concentrations are equal to the sand mean concentrations (Table B2). For the current experimental design, the nickel and PCB 1260 comparisons were the

\footnotetext{
${ }^{1}$ References cited in this appendix are included in the References section at the end of the main text.
} 
only comparisons with a power greater than 0.75 . From the overflow and silt/clay data one would conclude that the zinc, oil and grease, and TRPH overflow mean concentrations are equal to the silt/clay mean concentrations and the arsenic, cadmium, chromium, copper, lead, mercury, nickel, selenium, silver, barium, TOC, PCB 1242, and PCB 1260 overflow mean concentrations are not equal to the silt/clay mean concentrations (Table B5). For the current experimental design, the power of the comparison for arsenic, cadmium, chromium, copper, lead, mercury, nickel, selenium, silver, barium, PCB 1242, PCB 1260, and TOC was greater than 0.75. From the feed and bulk data one would conclude that the arsenic, cadmium, chromium, copper, lead, mercury, nickel, selenium, silver, zinc, barium, TOC, oil and grease, and TRPH feed mean concentrations are equal to the bulk mean concentrations and the PCB 1242 and PCB 1260 feed mean concentrations are not equal to the bulk mean concentrations (Table B8). For the current experimental design, the power of the comparison for arsenic, chromium, nickel, barium, PCB 1242, PCB 1260, oil and grease, and TRPH was greater than 0.75 . 


\begin{tabular}{|c|c|c|c|c|c|c|c|c|c|}
\hline \multicolumn{10}{|c|}{$\begin{array}{l}\text { Table B1 } \\
\text { Sand and Underflow Summary }\end{array}$} \\
\hline & & & Lower CL & & Upper CL & Lower CL & & Upper CL & \\
\hline Variable & TYPE & $\mathbf{N}$ & Mean & Mean & Mean & Std Dev & Std Dev & Std Dev & Std Err \\
\hline$\overline{\mathrm{AS}}$ & SAND & 2 & -0.185 & 0.45 & 1.0853 & 0.0315 & 0.0707 & 2.2564 & 0.05 \\
\hline AS & UNDERFLOW & 10 & 0.4376 & 0.4883 & 0.539 & 0.0487 & 0.0709 & 0.1294 & 0.0224 \\
\hline AS & $\operatorname{Diff}(1-2)$ & & -0.161 & -0.038 & 0.084 & 0.0495 & 0.0709 & 0.1243 & 0.0549 \\
\hline$C D$ & SAND & 2 & -0.087 & 0.04 & 0.1671 & 0.0063 & 0.0141 & 0.4513 & 0.01 \\
\hline CD & UNDERFLOW & 10 & -0.002 & 0.0591 & 0.12 & 0.0586 & 0.0851 & 0.1554 & 0.0269 \\
\hline CD & $\operatorname{Diff}(1-2)$ & & -0.159 & -0.019 & 0.1205 & 0.0565 & 0.0809 & 0.1419 & 0.0626 \\
\hline $\mathrm{CR}$ & SAND & 2 & -2.668 & 3.05 & 8.7678 & 0.2839 & 0.6364 & 20.308 & 0.45 \\
\hline $\mathrm{CR}$ & UNDERFLOW & 10 & 2.4997 & 2.896 & 3.2923 & 0.3811 & 0.554 & 1.0114 & 0.1752 \\
\hline $\mathrm{CR}$ & $\operatorname{Diff}(1-2)$ & & -0.817 & 0.154 & 1.1253 & 0.3932 & 0.5628 & 0.9876 & 0.4359 \\
\hline CU & SAND & 2 & -71.91 & 10.05 & 92.005 & 4.0696 & 9.1217 & 291.07 & 6.45 \\
\hline $\mathrm{CU}$ & UNDERFLOW & 10 & 2.0019 & 3.386 & 4.7701 & 1.3309 & 1.9349 & 3.5324 & 0.6119 \\
\hline $\mathrm{CU}$ & $\operatorname{Diff}(1-2)$ & & 0.763 & 6.664 & 12.565 & 2.389 & 3.4191 & 6.0002 & 2.6484 \\
\hline $\mathrm{PB}$ & SAND & 2 & -26.17 & 5.6 & 37.366 & 1.5774 & 3.5355 & 112.82 & 2.5 \\
\hline $\mathrm{PB}$ & UNDERFLOW & 10 & 2.2494 & 2.937 & 3.6246 & 0.6611 & 0.9612 & 1.7547 & 0.3039 \\
\hline $\mathrm{PB}$ & Diff $(1-2)$ & & 0.173 & 2.663 & 5.153 & 1.0081 & 1.4427 & 2.5319 & 1.1175 \\
\hline HG & SAND & 2 & -0.097 & 0.03 & 0.1571 & 0.0063 & 0.0141 & 0.4513 & 0.01 \\
\hline HG & UNDERFLOW & 10 & 0.02 & 0.02 & 0.02 & & 0 & & 0 \\
\hline HG & $\operatorname{Diff}(1-2)$ & & 0.0023 & 0.01 & 0.0177 & 0.0031 & 0.0045 & 0.0078 & 0.0035 \\
\hline NI & SAND & 2 & -1.612 & 2.2 & 6.0119 & 0.1893 & 0.4243 & 13.538 & 0.3 \\
\hline NI & UNDERFLOW & 10 & 2.1989 & 2.578 & 2.9571 & 0.3645 & 0.5299 & 0.9674 & 0.1676 \\
\hline NI & Diff $(1-2)$ & & -1.276 & -0.378 & 0.52 & 0.3636 & 0.5203 & 0.9131 & 0.403 \\
\hline $\mathrm{SE}$ & SAND & 2 & 0.1 & 0.1 & 0.1 & . & 0 & . & 0 \\
\hline $\mathrm{SE}$ & UNDERFLOW & 10 & 0.1 & 0.1 & 0.1 & . & 0 & . & 0 \\
\hline $\mathrm{SE}$ & Diff $(1-2)$ & & & 0 & & . & 0 & - & . \\
\hline AG & SAND & 2 & -0.871 & 0.4 & 1.6706 & 0.0631 & 0.1414 & 4.5128 & 0.1 \\
\hline AG & UNDERFLOW & 10 & 0.0615 & 0.08 & 0.0985 & 0.0178 & 0.0258 & 0.0471 & 0.0082 \\
\hline AG & Diff $(1-2)$ & & 0.232 & 0.32 & 0.408 & 0.0356 & 0.051 & 0.0895 & 0.0395 \\
\hline ZN & SAND & 2 & -8.101 & 13.5 & 35.101 & 1.0726 & 2.4042 & 76.717 & 1.7 \\
\hline ZN & UNDERFLOW & 10 & 4.9366 & 5.431 & 5.9254 & 0.4754 & 0.6912 & 1.2618 & 0.2186 \\
\hline ZN & $\operatorname{Diff}(1-2)$ & & 6.3362 & 8.069 & 9.8018 & 0.7015 & 1.004 & 1.7619 & 0.7777 \\
\hline $\mathrm{BA}$ & SAND & 2 & -4.294 & 4.6 & 13.494 & 0.4417 & 0.9899 & 31.589 & 0.7 \\
\hline $\mathrm{BA}$ & UNDERFLOW & 10 & 3.7931 & 5.052 & 6.3109 & 1.2104 & 1.7598 & 3.2127 & 0.5565 \\
\hline $\mathrm{BA}$ & Diff $(1-2)$ & & -3.384 & -0.452 & 2.4796 & 1.1868 & 1.6986 & 2.9809 & 1.3157 \\
\hline pcb 1242 & SAND & 2 & -559.8 & 444 & 1447.8 & 49.845 & 111.72 & 3565.1 & 79 \\
\hline pcb_1242 & UNDERFLOW & 10 & 126.31 & 144.03 & 161.75 & 17.035 & 24.767 & 45.214 & 7.8319 \\
\hline pcb_1242 & Diff $(1-2)$ & & 226.74 & 299.97 & 373.2 & 29.646 & 42.429 & 74.461 & 32.866 \\
\hline $\mathrm{pcb}-1260$ & SAND & 2 & -71.36 & 21.4 & 114.16 & 4.6059 & 10.324 & 329.43 & 7.3 \\
\hline pcb_1260 & UNDERFLOW & 10 & 8.3325 & 11.91 & 15.487 & 3.4399 & 5.001 & 9.1298 & 1.5814 \\
\hline pcb_1260 & Diff $(1-2)$ & & -0.45 & 9.49 & 19.43 & 4.024 & 5.7591 & 10.107 & 4.461 \\
\hline toc - & SAND & 2 & -788.6 & 1435 & 3658.6 & 110.42 & 247.49 & 7897.4 & 175 \\
\hline toc & UNDERFLOW & 10 & 539.92 & 1019 & 1498.1 & 460.65 & 669.71 & 1222.6 & 211.78 \\
\hline toc & $\operatorname{Diff}(1-2)$ & & -688.8 & 416 & 1520.8 & 447.28 & 640.14 & 1123.4 & 495.85 \\
\hline OG & SAND & 2 & -122.2 & 43 & 208.18 & 8.2024 & 18.385 & 586.66 & 13 \\
\hline OG & UNDERFLOW & 10 & 14.003 & 17.55 & 21.097 & 3.4102 & 4.9579 & 9.0512 & 1.5678 \\
\hline OG & Diff $(1-2)$ & & 12.543 & 25.45 & 38.357 & 5.2251 & 7.4781 & 13.124 & 5.7925 \\
\hline TRPH & SAND & 2 & -97.5 & 10.5 & 118.5 & 5.3631 & 12.021 & 383.59 & 8.5 \\
\hline TRPH & UNDERFLOW & 10 & 20.058 & 20.85 & 21.642 & 0.7613 & 1.1068 & 2.0206 & 0.35 \\
\hline TRPH & Diff $(1-2)$ & & -17.16 & -10.35 & -3.544 & 2.7555 & 3.9437 & 6.9209 & 3.0548 \\
\hline
\end{tabular}




\begin{tabular}{|c|c|c|c|c|c|}
\hline \multicolumn{6}{|c|}{$\begin{array}{l}\text { Table B2 } \\
\text { Sand and Underflow T-Test Results }\end{array}$} \\
\hline Variable & Method & Variances & $\mathrm{DF}$ & $t$ Value & $\operatorname{Pr}>|t|$ \\
\hline AS & Pooled & Equal & 10 & -0.70 & 0.5012 \\
\hline AS & Satterthwaite & Unequal & 1.44 & -0.70 & 0.5803 \\
\hline $\mathrm{CD}$ & Pooled & Equal & 10 & -0.30 & 0.7669 \\
\hline$C D$ & Satterthwaite & Unequal & 9.95 & -0.66 & 0.5215 \\
\hline $\mathrm{CR}$ & Pooled & Equal & 10 & 0.35 & 0.7312 \\
\hline $\mathrm{CR}$ & Satterthwaite & Unequal & 1.32 & 0.32 & 0.7928 \\
\hline $\mathrm{CU}$ & Pooled & Equal & 10 & 2.52 & 0.0306 \\
\hline $\mathrm{CU}$ & Satterthwaite & Unequal & 1.02 & 1.03 & 0.4886 \\
\hline $\mathrm{PB}$ & Pooled & Equal & 10 & 2.38 & 0.0384 \\
\hline $\mathrm{PB}$ & Satterthwaite & Unequal & 1.03 & 1.06 & 0.4782 \\
\hline HG & Pooled & Equal & 10 & 2.89 & 0.0162 \\
\hline HG & Satterthwaite & Unequal & 1 & 1.00 & 0.5000 \\
\hline NI & Pooled & Equal & 10 & -0.94 & 0.3704 \\
\hline $\mathrm{NI}$ & Satterthwaite & Unequal & 1.7 & -1.10 & 0.4026 \\
\hline $\mathrm{SE}$ & Pooled & Equal & 10 & . & . \\
\hline $\mathrm{SE}$ & Satterthwaite & Unequal & 10 & . & . \\
\hline AG & Pooled & Equal & 10 & 8.10 & $<.0001$ \\
\hline$A G$ & Satterthwaite & Unequal & 1.01 & 3.19 & 0.1908 \\
\hline $\mathrm{ZN}$ & Pooled & Equal & 10 & 10.38 & $<.0001$ \\
\hline $\mathrm{ZN}$ & Satterthwaite & Unequal & 1.03 & 4.71 & 0.1273 \\
\hline $\mathrm{BA}$ & Pooled & Equal & 10 & -0.34 & 0.7383 \\
\hline $\mathrm{BA}$ & Satterthwaite & Unequal & 2.55 & -0.51 & 0.6536 \\
\hline pcb_1242 & Pooled & Equal & 10 & 9.13 & $<.0001$ \\
\hline $\mathrm{pcb}_{-} 1242$ & Satterthwaite & Unequal & 1.02 & 3.78 & 0.1609 \\
\hline $\mathrm{pcb}^{-} 1260$ & Pooled & Equal & 10 & 2.13 & 0.0593 \\
\hline pcb_1260 & Satterthwaite & Unequal & 1.1 & 1.27 & 0.4103 \\
\hline toc & Pooled & Equal & 10 & 0.84 & 0.4211 \\
\hline toc & Satterthwaite & Unequal & 4.9 & 1.51 & 0.1915 \\
\hline OG & Pooled & Equal & 10 & 4.39 & 0.0013 \\
\hline OG & Satterthwaite & Unequal & 1.03 & 1.94 & 0.2970 \\
\hline TRPH & Pooled & Equal & 10 & -3.39 & 0.0069 \\
\hline TRPH & Satterthwaite & Unequal & 1 & -1.22 & 0.4375 \\
\hline
\end{tabular}

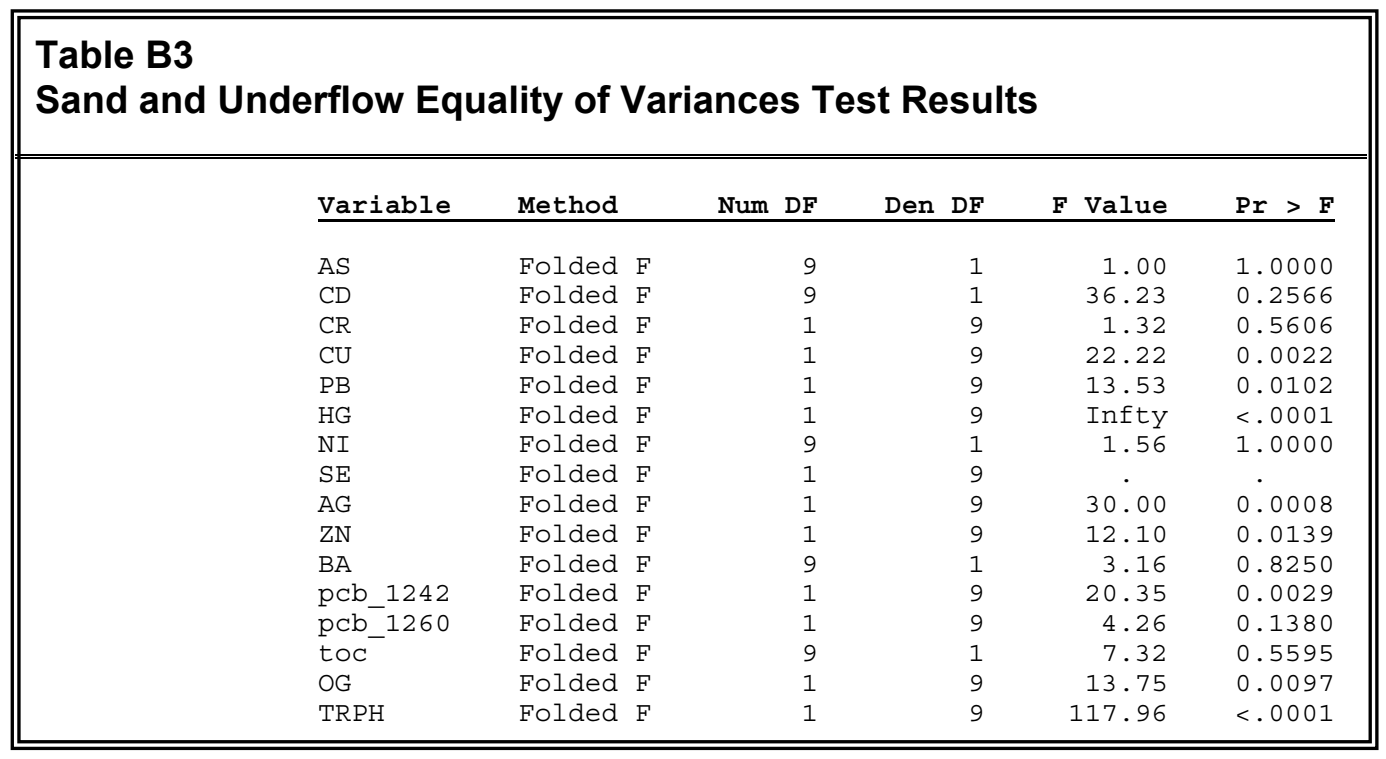




\begin{tabular}{|c|c|c|c|c|c|c|c|c|c|}
\hline \multicolumn{10}{|c|}{$\begin{array}{l}\text { Table B4 } \\
\text { Fines (Silt/Clay) and Overflow Summary }\end{array}$} \\
\hline \multirow[b]{2}{*}{ Variable } & \multirow[b]{2}{*}{ TYPE } & \multirow{2}{*}{\multicolumn{2}{|c|}{ Lower CL }} & \multirow[b]{2}{*}{ Mean } & \multirow{2}{*}{$\begin{array}{r}\text { Upper CL } \\
\text { Mean }\end{array}$} & \multirow{2}{*}{$\begin{array}{l}\text { Lower CL } \\
\text { Std Dev }\end{array}$} & \multirow{2}{*}{\multicolumn{2}{|c|}{$\begin{array}{ll} & \text { Upper CL } \\
\text { Std Dev } & \text { Std Dev }\end{array}$}} & \multirow[b]{2}{*}{ Std Err } \\
\hline & & & & & & & & & \\
\hline AS & FINES & 2 & 4.4147 & 5.05 & 5.6853 & 0.0315 & 0.0707 & 2.2564 & 0.05 \\
\hline AS & OVERFLOW & 10 & 3.1251 & 3.445 & 3.7649 & 0.3076 & 0.4472 & 0.8165 & 0.1414 \\
\hline AS & Diff $(1-2)$ & & 0.8717 & 1.605 & 2.3383 & 0.2969 & 0.4249 & 0.7456 & 0.3291 \\
\hline$C D$ & FINES & 2 & 0.6562 & 1.355 & 2.0538 & 0.0347 & 0.0778 & 2.482 & 0.055 \\
\hline$C D$ & OVERFLOW & 10 & 0.7471 & 0.8208 & 0.8945 & 0.0709 & 0.1031 & 0.1882 & 0.0326 \\
\hline$C D$ & Diff $(1-2)$ & & 0.3602 & 0.5342 & 0.7082 & 0.0705 & 0.1008 & 0.177 & 0.0781 \\
\hline $\mathrm{CR}$ & FINES & 2 & 50.09 & 79.95 & 109.81 & 1.4827 & 3.3234 & 106.05 & 2.35 \\
\hline $\mathrm{CR}$ & OVERFLOW & 10 & 43.629 & 48.75 & 53.871 & 4.9243 & 7.1592 & 13.07 & 2.2639 \\
\hline $\mathrm{CR}$ & Diff $(1-2)$ & & 19.338 & 31.2 & 43.062 & 4.802 & 6.8726 & 12.061 & 5.3235 \\
\hline $\mathrm{CU}$ & FINES & 2 & 55.555 & 75.25 & 94.945 & 0.978 & 2.192 & 69.948 & 1.55 \\
\hline $\mathrm{CU}$ & OVERFLOW & 10 & 46.111 & 50 & 53.889 & 3.7398 & 5.4371 & 9.9261 & 1.7194 \\
\hline $\mathrm{CU}$ & Diff $(1-2)$ & & 16.268 & 25.25 & 34.232 & 3.6365 & 5.2045 & 9.1335 & 4.0314 \\
\hline $\mathrm{PB}$ & FINES & 2 & 65.623 & 101.2 & 136.78 & 1.7667 & 3.9598 & 126.36 & 2.8 \\
\hline $\mathrm{PB}$ & OVERFLOW & 10 & 54.371 & 59.59 & 64.809 & 5.0183 & 7.2957 & 13.319 & 2.3071 \\
\hline $\mathrm{PB}$ & Diff $(1-2)$ & & 29.47 & 41.61 & 53.75 & 4.9146 & 7.0337 & 12.344 & 5.4483 \\
\hline HG & FINES & 2 & 3.3229 & 3.45 & 3.5771 & 0.0063 & 0.0141 & 0.4513 & 0.01 \\
\hline HG & OVERFLOW & 10 & 1.1581 & 1.294 & 1.4299 & 0.1307 & 0.19 & 0.3468 & 0.0601 \\
\hline HG & Diff $(1-2)$ & & 1.8448 & 2.156 & 2.4672 & 0.126 & 0.1803 & 0.3164 & 0.1397 \\
\hline $\mathrm{NI}$ & FINES & 2 & 20.747 & 27.1 & 33.453 & 0.3155 & 0.7071 & 22.564 & 0.5 \\
\hline NI & OVERFLOW & 10 & 17.502 & 18.98 & 20.458 & 1.4207 & 2.0655 & 3.7708 & 0.6532 \\
\hline NI & $\operatorname{Diff}(1-2)$ & & 4.7162 & 8.12 & 11.524 & 1.378 & 1.9722 & 3.4611 & 1.5277 \\
\hline $\mathrm{SE}$ & FINES & 2 & -0.171 & 1.1 & 2.3706 & 0.0631 & 0.1414 & 4.5128 & 0.1 \\
\hline $\mathrm{SE}$ & OVERFLOW & 10 & 0.5579 & 0.6489 & 0.7399 & 0.0875 & 0.1272 & 0.2321 & 0.0402 \\
\hline $\mathrm{SE}$ & $\operatorname{Diff}(1-2)$ & & 0.2291 & 0.4511 & 0.6731 & 0.0899 & 0.1287 & 0.2258 & 0.0997 \\
\hline $\mathrm{AG}$ & FINES & 2 & -0.377 & 0.8995 & 2.1765 & 0.0634 & 0.1421 & 4.5353 & 0.1005 \\
\hline AG & OVERFLOW & 10 & 0.4538 & 0.5292 & 0.6046 & 0.0725 & 0.1055 & 0.1925 & 0.0333 \\
\hline $\mathrm{AG}$ & Diff $(1-2)$ & & 0.181 & 0.3703 & 0.5596 & 0.0766 & 0.1097 & 0.1925 & 0.085 \\
\hline $\mathrm{ZN}$ & FINES & 2 & -1699 & 148.56 & 1996.6 & 91.769 & 205.69 & 6563.6 & 145.45 \\
\hline $\mathrm{ZN}$ & OVERFLOW & 10 & 106.52 & 116.94 & 127.36 & 10.022 & 14.57 & 26.599 & 4.6074 \\
\hline $\mathrm{ZN}$ & Diff $(1-2)$ & & -83.15 & 31.615 & 146.38 & 46.463 & 66.497 & 116.7 & 51.509 \\
\hline $\mathrm{BA}$ & FINES & 2 & 72.734 & 104.5 & 136.27 & 1.5774 & 3.5355 & 112.82 & 2.5 \\
\hline $\mathrm{BA}$ & OVERFLOW & 10 & 71.968 & 79.35 & 86.732 & 7.0976 & 10.319 & 18.838 & 3.2631 \\
\hline $\mathrm{BA}$ & Diff $(1-2)$ & & 8.1449 & 25.15 & 42.155 & 6.8843 & 9.8528 & 17.291 & 7.632 \\
\hline pcb 1242 & FINES & 2 & 4345.6 & 5927.5 & 7509.4 & 78.553 & 176.07 & 5618.4 & 124.5 \\
\hline $\mathrm{pcb}-1242$ & OVERFLOW & 10 & 3642.6 & 4037.9 & 4433.2 & 380.1 & 552.61 & 1008.8 & 174.75 \\
\hline $\mathrm{pcb}^{-} 1242$ & Diff $(1-2)$ & & 979.7 & 1889.6 & 2799.5 & 368.36 & 527.2 & 925.2 & 408.37 \\
\hline $\mathrm{pcb} 1260$ & FINES & 2 & 298.44 & 317.5 & 336.56 & 0.9464 & 2.1213 & 67.692 & 1.5 \\
\hline $\mathrm{pcb}_{-} 1260$ & OVERFLOW & 10 & 92.963 & 109.9 & 126.84 & 16.285 & 23.676 & 43.224 & 7.4871 \\
\hline $\mathrm{pcb}_{-1260}$ & Diff $(1-2)$ & & 168.82 & 207.6 & 246.38 & 15.701 & 22.471 & 39.436 & 17.406 \\
\hline toc & FINES & 2 & -66573 & 21100 & 108773 & 4353.6 & 9758.1 & 311382 & 6900 \\
\hline toc & OVERFLOW & 10 & 42701 & 46480 & 50259 & 3633.9 & 5283.1 & 9644.8 & 1670.6 \\
\hline toc & Diff $(1-2)$ & & -35538 & -25380 & -15222 & 4112.4 & 5885.7 & 10329 & 4559.1 \\
\hline OG & FINES & 2 & -859.2 & 475 & 1809.2 & 66.25 & 148.49 & 4738.4 & 105 \\
\hline OG & OVERFLOW & 10 & 351.08 & 435 & 518.92 & 80.688 & 117.31 & 214.16 & 37.096 \\
\hline OG & Diff $(1-2)$ & & -168.5 & 40 & 248.47 & 84.397 & 120.79 & 211.98 & 93.563 \\
\hline TRPH & FINES & 2 & -619.4 & 270 & 1159.4 & 44.167 & 98.995 & 3158.9 & 70 \\
\hline TRPH & OVERFLOW & 10 & 271.76 & 338 & 404.24 & 63.688 & 92.592 & 169.04 & 29.28 \\
\hline TRPH & Diff $(1-2)$ & & -228.9 & -68 & 92.945 & 65.157 & 93.252 & 163.65 & 72.233 \\
\hline
\end{tabular}




\begin{tabular}{|c|c|c|c|c|c|}
\hline \multicolumn{6}{|c|}{$\begin{array}{l}\text { Table B5 } \\
\text { Fines (Silt/Clay) and Overflow T-Test Results }\end{array}$} \\
\hline Variable & Method & Variances & $\mathrm{DF}$ & $t$ Value & $\operatorname{Pr}>|t|$ \\
\hline AS & Pooled & Equal & 10 & 4.88 & 0.0006 \\
\hline AS & Satterthwaite & Unequal & 9.99 & 10.70 & $<.0001$ \\
\hline$C D$ & Pooled & Equal & 10 & 6.84 & $<.0001$ \\
\hline$C D$ & Satterthwaite & Unequal & 1.8 & 8.36 & 0.0190 \\
\hline $\mathrm{CR}$ & Pooled & Equal & 10 & 5.86 & 0.0002 \\
\hline $\mathrm{CR}$ & Satterthwaite & Unequal & 3.39 & 9.56 & 0.0014 \\
\hline $\mathrm{CU}$ & Pooled & Equal & 10 & 6.26 & $<.0001$ \\
\hline $\mathrm{CU}$ & Satterthwaite & Unequal & 4.26 & 10.91 & 0.0003 \\
\hline PB & Pooled & Equal & 10 & 7.64 & $<.0001$ \\
\hline $\mathrm{PB}$ & Satterthwaite & Unequal & 2.68 & 11.47 & 0.0024 \\
\hline HG & Pooled & Equal & 10 & 15.44 & $<.0001$ \\
\hline HG & Satterthwaite & Unequal & 9.44 & 35.40 & $<.0001$ \\
\hline $\mathrm{NI}$ & Pooled & Equal & 10 & 5.32 & 0.0003 \\
\hline NI & Satterthwaite & Unequal & 5.53 & 9.87 & 0.0001 \\
\hline $\mathrm{SE}$ & Pooled & Equal & 10 & 4.53 & 0.0011 \\
\hline SE & Satterthwaite & Unequal & 1.35 & 4.19 & 0.0993 \\
\hline AG & Pooled & Equal & 10 & 4.36 & 0.0014 \\
\hline AG & Satterthwaite & Unequal & 1.23 & 3.50 & 0.1392 \\
\hline $\mathrm{ZN}$ & Pooled & Equal & 10 & 0.61 & 0.5531 \\
\hline $\mathrm{ZN}$ & Satterthwaite & Unequal & 1 & 0.22 & 0.8638 \\
\hline $\mathrm{BA}$ & Pooled & Equal & 10 & 3.30 & 0.0081 \\
\hline $\mathrm{BA}$ & Satterthwaite & Unequal & 5.53 & 6.12 & 0.0012 \\
\hline pcb_1242 & Pooled & Equal & 10 & 4.63 & 0.0009 \\
\hline $\mathrm{pcb}^{-} 1242$ & Satterthwaite & Unequal & 6.16 & 8.81 & 0.0001 \\
\hline $\mathrm{pcb}^{-} 1260$ & Pooled & Equal & 10 & 11.93 & $<.0001$ \\
\hline $\mathrm{pcb}^{-} 1260$ & Satterthwaite & Unequal & 9.6 & 27.19 & $<.0001$ \\
\hline toc ${ }^{-}$ & Pooled & Equal & 10 & -5.57 & 0.0002 \\
\hline toc & Satterthwaite & Unequal & 1.12 & -3.57 & 0.1521 \\
\hline OG & Pooled & Equal & 10 & 0.43 & 0.6781 \\
\hline OG & Satterthwaite & Unequal & 1.26 & 0.36 & 0.7702 \\
\hline TRPH & Pooled & Equal & 10 & -0.94 & 0.3687 \\
\hline TRPH & Satterthwaite & Unequal & 1.38 & -0.90 & 0.4992 \\
\hline
\end{tabular}

\begin{tabular}{|c|c|c|c|c|c|c|c|}
\hline \multicolumn{8}{|c|}{$\begin{array}{l}\text { Table B6 } \\
\text { Fines (Silt/Clay) and Overflow Equality of Variances Test Results }\end{array}$} \\
\hline Variable & Method & Num & $\mathrm{DF}$ & Den & $\mathrm{DF}$ & F Value & $\operatorname{Pr}>F$ \\
\hline AS & Folded F & & 9 & & 1 & 40.01 & 0.2443 \\
\hline $\mathrm{CD}$ & Folded F & & 9 & & 1 & 1.76 & 1.0000 \\
\hline $\mathrm{CR}$ & Folded F & & 9 & & 1 & 4.64 & 0.6930 \\
\hline $\mathrm{CU}$ & Folded F & & 9 & & 1 & 6.15 & 0.6075 \\
\hline PB & Folded F & & 9 & & 1 & 3.39 & 0.7990 \\
\hline HG & Folded F & & 9 & & 1 & 180.47 & 0.1154 \\
\hline NI & Folded F & & 9 & & 1 & 8.53 & 0.5201 \\
\hline $\mathrm{SE}$ & Folded F & & 1 & & 9 & 1.24 & 0.5897 \\
\hline $\mathrm{AG}$ & Folded F & & 1 & & 9 & 1.82 & 0.4214 \\
\hline $\mathrm{ZN}$ & Folded F & & 1 & & 9 & 199.30 & $<.0001$ \\
\hline $\mathrm{BA}$ & Folded F & & 9 & & 1 & 8.52 & 0.5205 \\
\hline pcb_1242 & Folded F & & 9 & & 1 & 9.85 & 0.4854 \\
\hline $\mathrm{pcb}_{-1260}$ & Folded F & & 9 & & 1 & 124.57 & 0.1389 \\
\hline toc & Folded F & & 1 & & 9 & 3.41 & 0.1956 \\
\hline OG & Folded F & & 1 & & 9 & 1.60 & 0.4747 \\
\hline TRPH & Folded F & & 1 & & 9 & 1.14 & 0.6257 \\
\hline
\end{tabular}




\begin{tabular}{|c|c|c|c|c|c|c|c|c|c|c|}
\hline \multicolumn{11}{|c|}{$\begin{array}{l}\text { Table B7 } \\
\text { Bulk and Feed Summary }\end{array}$} \\
\hline Variable & TYPE & & $\mathbf{N}$ & $\begin{array}{r}\text { Lower CL } \\
\text { Mean }\end{array}$ & Mean & $\begin{array}{r}\text { Upper CL } \\
\text { Mean }\end{array}$ & $\begin{array}{r}\text { Lower CL } \\
\text { Std Dev }\end{array}$ & Std Dev & $\begin{array}{r}\text { Upper CL } \\
\text { Std Dev }\end{array}$ & Std Err \\
\hline AS & BULK & & 2 & 0.9294 & 2.2 & 3.4706 & 0.0631 & 0.1414 & 4.5128 & 0.1 \\
\hline AS & FEED & & 10 & 2.1377 & 2.805 & 3.4723 & 0.6416 & 0.9328 & 1.7028 & 0.295 \\
\hline AS & Diff & $(1-2)$ & & -2.134 & -0.605 & 0.9242 & 0.6191 & 0.886 & 1.5549 & 0.6863 \\
\hline$C D$ & BULK & & 2 & 0.5473 & 0.6045 & 0.6617 & 0.0028 & 0.0064 & 0.2031 & 0.0045 \\
\hline$C D$ & FEED & & 10 & 0.4583 & 0.5809 & 0.7035 & 0.1179 & 0.1714 & 0.3128 & 0.0542 \\
\hline$C D$ & Diff & $(1-2)$ & & -0.257 & 0.0236 & 0.3042 & 0.1136 & 0.1626 & 0.2853 & 0.1259 \\
\hline $\mathrm{CR}$ & BULK & & 2 & 18.364 & 29.8 & 41.236 & 0.5679 & 1.2728 & 40.615 & 0.9 \\
\hline $\mathrm{CR}$ & FEED & & 10 & 29.449 & 38.44 & 47.431 & 8.6451 & 12.569 & 22.945 & 3.9745 \\
\hline $\mathrm{CR}$ & Diff & $(1-2)$ & & -29.23 & -8.64 & 11.951 & 8.336 & 11.93 & 20.937 & 9.2412 \\
\hline CU & BULK & & 2 & -37.08 & 32.8 & 102.68 & 3.4702 & 7.7782 & 248.2 & 5.5 \\
\hline $\mathrm{CU}$ & FEED & & 10 & 28.542 & 37.81 & 47.078 & 8.9111 & 12.955 & 23.651 & 4.0968 \\
\hline $\mathrm{CU}$ & Diff & $(1-2)$ & & -26.64 & -5.01 & 16.623 & 8.7579 & 12.534 & 21.997 & 9.709 \\
\hline $\mathrm{PB}$ & BULK & & 2 & 33.535 & 43.7 & 53.865 & 0.5048 & 1.1314 & 36.102 & 0.8 \\
\hline $\mathrm{PB}$ & FEED & & 10 & 32.818 & 41.69 & 50.562 & 8.5304 & 12.402 & 22.641 & 3.9218 \\
\hline $\mathrm{PB}$ & Diff & $(1-2)$ & & -18.31 & 2.01 & 22.325 & 8.2244 & 11.771 & 20.657 & 9.1176 \\
\hline HG & BULK & & 2 & 1.0215 & 1.085 & 1.1485 & 0.0032 & 0.0071 & 0.2256 & 0.005 \\
\hline HG & FEED & & 10 & 0.6547 & 0.8834 & 1.1121 & 0.2199 & 0.3198 & 0.5838 & 0.1011 \\
\hline HG & Diff & $(1-2)$ & & -0.322 & 0.2016 & 0.7252 & 0.212 & 0.3034 & 0.5324 & 0.235 \\
\hline $\mathrm{NI}$ & BULK & & 2 & 4.4469 & 10.8 & 17.153 & 0.3155 & 0.7071 & 22.564 & 0.5 \\
\hline NI & FEED & & 10 & 12.387 & 15.718 & 19.049 & 3.203 & 4.6566 & 8.5012 & 1.4726 \\
\hline $\mathrm{NI}$ & Diff & $(1-2)$ & & -12.55 & -4.918 & 2.7162 & 3.0906 & 4.4233 & 7.7626 & 3.4263 \\
\hline $\mathrm{SE}$ & BULK & & 2 & 0.4931 & 0.4995 & 0.5059 & 0.0003 & 0.0007 & 0.0226 & 0.0005 \\
\hline $\mathrm{SE}$ & FEED & & 10 & 0.3762 & 0.5116 & 0.647 & 0.1302 & 0.1892 & 0.3455 & 0.0598 \\
\hline $\mathrm{SE}$ & Diff & $(1-2)$ & & -0.322 & -0.012 & 0.2977 & 0.1254 & 0.1795 & 0.315 & 0.1391 \\
\hline$A G$ & BULK & & 2 & -2.048 & 0.4995 & 3.0471 & 0.1265 & 0.2835 & 9.0481 & 0.2005 \\
\hline AG & FEED & & 10 & 0.2617 & 0.3447 & 0.4277 & 0.0798 & 0.116 & 0.2117 & 0.0367 \\
\hline$A G$ & Diff & $(1-2)$ & & -0.09 & 0.1548 & 0.3997 & 0.0992 & 0.1419 & 0.2491 & 0.1099 \\
\hline $\mathrm{ZN}$ & BULK & & 2 & 49.417 & 76.1 & 102.78 & 1.325 & 2.9698 & 94.768 & 2.1 \\
\hline ZN & FEED & & 10 & 62.753 & 81.4 & 100.05 & 17.93 & 26.067 & 47.589 & 8.2432 \\
\hline ZN & Diff & $(1-2)$ & & -48.01 & -5.3 & 37.412 & 17.291 & 24.747 & 43.43 & 19.169 \\
\hline BA & BULK & & 2 & 12.99 & 42.85 & 72.71 & 1.4827 & 3.3234 & 106.05 & 2.35 \\
\hline$B A$ & FEED & & 10 & 46.266 & 61.12 & 75.974 & 14.283 & 20.765 & 37.908 & 6.5664 \\
\hline BA & Diff & $(1-2)$ & & -52.32 & -18.27 & 15.777 & 13.784 & 19.727 & 34.62 & 15.281 \\
\hline pcb_1242 & BULK & & 2 & 3341.5 & 3754.5 & 4167.5 & 20.506 & 45.962 & 1466.7 & 32.5 \\
\hline pcb_1242 & FEED & & 10 & 2356 & 2713.8 & 3071.6 & 344.04 & 500.17 & 913.12 & 158.17 \\
\hline $\mathrm{pcb}^{-} 1242$ & Diff & $(1-2)$ & & 221.36 & 1040.7 & 1860 & 331.7 & 474.73 & 833.12 & 367.72 \\
\hline $\mathrm{pcb}^{-} 1260$ & BULK & & 2 & 2.152 & 39 & 75.848 & 1.8298 & 4.1012 & 130.87 & 2.9 \\
\hline pcb_1260 & FEED & & 10 & 114.55 & 144.96 & 175.37 & 29.245 & 42.517 & 77.62 & 13.445 \\
\hline $\mathrm{pcb}^{-} 1260$ & Diff & $(1-2)$ & & -175.6 & -106 & -36.31 & 28.198 & 40.356 & 70.822 & 31.26 \\
\hline toc ${ }^{-}$ & BULK & & 2 & 12053 & 27300 & 42547 & 757.14 & 1697.1 & 54153 & 1200 \\
\hline toc & FEED & & 10 & 20471 & 26500 & 32529 & 5797 & 8427.9 & 15386 & 2665.1 \\
\hline toc & Diff & $(1-2)$ & & -13030 & 800 & 14630 & 5599.1 & 8013.4 & 14063 & 6207.1 \\
\hline OG & BULK & & 2 & 92.938 & 220 & 347.06 & 6.3095 & 14.142 & 451.28 & 10 \\
\hline OG & FEED & & 10 & 270.85 & 332 & 393.15 & 58.795 & 85.479 & 156.05 & 27.031 \\
\hline OG & Diff & $(1-2)$ & & -252.2 & -112 & 28.171 & 56.747 & 81.216 & 142.53 & 62.909 \\
\hline TRPH & BULK & & 2 & 121.47 & 185 & 248.53 & 3.1548 & 7.0711 & 225.64 & 5 \\
\hline TRPH & FEED & & 10 & 209.04 & 259 & 308.96 & 48.034 & 69.833 & 127.49 & 22.083 \\
\hline TRPH & Diff & $(1-2)$ & & -188.4 & -74 & 40.406 & 46.316 & 66.287 & 116.33 & 51.346 \\
\hline
\end{tabular}




\begin{tabular}{|c|c|c|c|c|c|}
\hline \multicolumn{6}{|c|}{$\begin{array}{l}\text { Table B8 } \\
\text { Bulk and Feed T-Test Results }\end{array}$} \\
\hline Variable & Method & Variances & $\mathrm{DF}$ & t Value & $\operatorname{Pr}>|t|$ \\
\hline AS & Pooled & Equal & 10 & -0.88 & 0.3987 \\
\hline AS & Satterthwaite & Unequal & 10 & -1.94 & 0.0807 \\
\hline $\mathrm{CD}$ & Pooled & Equal & 10 & 0.19 & 0.8551 \\
\hline $\mathrm{CD}$ & Satterthwaite & Unequal & 9.12 & 0.43 & 0.6744 \\
\hline $\mathrm{CR}$ & Pooled & Equal & 10 & -0.93 & 0.3718 \\
\hline $\mathrm{CR}$ & Satterthwaite & Unequal & 9.72 & -2.12 & 0.0608 \\
\hline $\mathrm{CU}$ & Pooled & Equal & 10 & -0.52 & 0.6171 \\
\hline $\mathrm{CU}$ & Satterthwaite & Unequal & 2.34 & -0.73 & 0.5313 \\
\hline $\mathrm{PB}$ & Pooled & Equal & 10 & 0.22 & 0.8300 \\
\hline $\mathrm{PB}$ & Satterthwaite & Unequal & 9.61 & 0.50 & 0.6268 \\
\hline HG & Pooled & Equal & 10 & 0.86 & 0.4110 \\
\hline HG & Satterthwaite & Unequal & 9.04 & 1.99 & 0.0775 \\
\hline NI & Pooled & Equal & 10 & -1.44 & 0.1817 \\
\hline NI & Satterthwaite & Unequal & 10 & -3.16 & 0.0101 \\
\hline $\mathrm{SE}$ & Pooled & Equal & 10 & -0.09 & 0.9324 \\
\hline $\mathrm{SE}$ & Satterthwaite & Unequal & 9 & -0.20 & 0.8443 \\
\hline AG & Pooled & Equal & 10 & 1.41 & 0.1894 \\
\hline AG & Satterthwaite & Unequal & 1.07 & 0.76 & 0.5798 \\
\hline $\mathrm{ZN}$ & Pooled & Equal & 10 & -0.28 & 0.7878 \\
\hline $\mathrm{ZN}$ & Satterthwaite & Unequal & 9.83 & -0.62 & 0.5474 \\
\hline $\mathrm{BA}$ & Pooled & Equal & 10 & -1.20 & 0.2594 \\
\hline $\mathrm{BA}$ & Satterthwaite & Unequal & 9.98 & -2.62 & 0.0257 \\
\hline pcb 1242 & Pooled & Equal & 10 & 2.83 & 0.0178 \\
\hline $\mathrm{pcb}^{-} 1242$ & Satterthwaite & Unequal & 9.62 & 6.45 & $<.0001$ \\
\hline $\mathrm{pcb} 1260$ & Pooled & Equal & 10 & -3.39 & 0.0069 \\
\hline $\mathrm{pcb} 1260$ & Satterthwaite & Unequal & 9.67 & -7.70 & $<.0001$ \\
\hline toc & Pooled & Equal & 10 & 0.13 & 0.9000 \\
\hline toc & Satterthwaite & Unequal & 9.5 & 0.27 & 0.7902 \\
\hline OG & Pooled & Equal & 10 & -1.78 & 0.1054 \\
\hline OG & Satterthwaite & Unequal & 9.95 & -3.89 & 0.0031 \\
\hline TRPH & Pooled & Equal & 10 & -1.44 & 0.1801 \\
\hline TRPH & Satterthwaite & Unequal & 9.72 & -3.27 & 0.0088 \\
\hline
\end{tabular}

Table B9

Bulk and Feed Equality of Variances Test Results

\begin{tabular}{|c|c|c|c|c|c|}
\hline Variable & Method & Num DF & Den DF & F Value & $\operatorname{Pr}>\mathrm{F}$ \\
\hline AS & Folded F & 9 & 1 & 43.50 & 0.2343 \\
\hline $\mathrm{CD}$ & Folded F & 9 & 1 & 725.01 & 0.0576 \\
\hline $\mathrm{CR}$ & Folded F & 9 & 1 & 97.51 & 0.1569 \\
\hline $\mathrm{CU}$ & Folded F & 9 & 1 & 2.77 & 0.8739 \\
\hline $\mathrm{PB}$ & Folded F & 9 & 1 & 120.16 & 0.1414 \\
\hline HG & Folded F & 9 & 1 & 2044.94 & 0.0343 \\
\hline NI & Folded F & 9 & 1 & 43.37 & 0.2347 \\
\hline SE & Folded F & 9 & 1 & 71613.0 & $<.0001$ \\
\hline AG & Folded F & 1 & 9 & 5.98 & 0.0741 \\
\hline $\mathrm{ZN}$ & Folded F & 9 & 1 & 77.04 & 0.1764 \\
\hline $\mathrm{BA}$ & Folded F & 9 & 1 & 39.04 & 0.2472 \\
\hline pcb_1242 & Folded F & 9 & 1 & 118.42 & 0.1424 \\
\hline pcb_1260 & Folded F & 9 & 1 & 107.47 & 0.1495 \\
\hline toc & Folded F & 9 & 1 & 24.66 & 0.3102 \\
\hline OG & Folded F & 9 & 1 & 36.53 & 0.2555 \\
\hline TRPH & Folded F & 9 & 1 & 97.53 & 0.1569 \\
\hline
\end{tabular}




\section{Appendix C \\ Chemical Analysis Sample Listing, Data Validation, Raw Data Sheets}




\begin{tabular}{|c|c|c|c|c|c|}
\hline \multicolumn{6}{|c|}{$\begin{array}{l}\text { Table C1 } \\
\text { Green Bay Physical Separation Samples - ECB Lab ID \#s }\end{array}$} \\
\hline Sample/Analyte & TOC/TVS/O\&G/TRPH & PCBs & PAHs & Metals & Soot \\
\hline \multicolumn{6}{|c|}{ Demo } \\
\hline GB Underflow 1400-1715 (-1, -2) (solids) & 90838-47 & $90808-17$ & $\mathrm{~N} / \mathrm{A}$ & $90823-32$ & \\
\hline GB Feed 1400-1715-1 (solids) & $90848-52$ & $90818-22$ & $\mathrm{~N} / \mathrm{A}$ & $90833-37$ & \\
\hline GB Feed 1400-1715-2 (solids) & $90954-58$ & $90924-28$ & $\mathrm{~N} / \mathrm{A}$ & $90939-43$ & \\
\hline GB Overflow 1400-1715 $(-1,-2)$ (solids) & $90944-53$ & $90914-23$ & $\mathrm{~N} / \mathrm{A}$ & $90929-38$ & \\
\hline GB Overflow 1400-1715 -1 (supernatant) & & $90853-57$ & $\mathrm{~N} / \mathrm{A}$ & $90904,6,8,10,12$ & \\
\hline GB Overflow 1400-1715 -2 (supernatant) & & $90883-87$ & $\mathrm{~N} / \mathrm{A}$ & $90905,7,9,11,13$ & \\
\hline GB Feed 1400-1715 -1 (supernatant) & & $90858-62$ & $\mathrm{~N} / \mathrm{A}$ & $90894,6,8,900,02$ & \\
\hline GB Feed 1400-1715 -2 (supernatant) & & $90888-92$ & $\mathrm{~N} / \mathrm{A}$ & $90895,7,9,901,03$ & \\
\hline Supply Water & & 90789 & $\mathrm{~N} / \mathrm{A}$ & 90893 & \\
\hline MetPro Underflow & 92103-4 & 92099-100 & $\mathrm{N} / \mathrm{A}$ & $92107-8$ & \\
\hline MetPro Overflow & 92105-6 & $92101-2$ & $\mathrm{~N} / \mathrm{A}$ & $92109-10$ & \\
\hline MetPro Underflow Supernatant & & 92111 & $\mathrm{~N} / \mathrm{A}$ & 92113 & \\
\hline MetPro Overflow Supernatant & & 92112 & $\mathrm{~N} / \mathrm{A}$ & 92114 & \\
\hline Soot Samples & & & & & $92455-514$ \\
\hline Carbon Treated Supernatant & & 92412 & $\mathrm{~N} / \mathrm{A}$ & 92413 & \\
\hline \multicolumn{6}{|c|}{ Cell 4 Characterization } \\
\hline Cell 4, Bulk A,B & $89589-90$ & $89587-88$ & $89591-92$ & $89585-6$ & $90795-802$ \\
\hline Cell 4 Sand 1,2 & $93027-28$ & $93023-24$ & $\mathrm{~N} / \mathrm{A}$ & $93019-20$ & \\
\hline Silt/Clay 1,2 & $93029-30$ & $93025-26$ & $\mathrm{~N} / \mathrm{A}$ & $93021-22$ & \\
\hline Clay 1,2 Cell 4 & 94943-4 & $94940-1$ & $\mathrm{~N} / \mathrm{A}$ & $94937-8$ & \\
\hline Silt Cell 4 & 94945 & 94942 & $\mathrm{~N} / \mathrm{A}$ & 94939 & \\
\hline Soot Samples & & & & & $89607-18$ \\
\hline \multicolumn{6}{|c|}{ Cell 5 Characterization } \\
\hline Bulk 1,2,3 & 89331-33 & $89343-45$ & $89349-51$ & $89337-39$ & \\
\hline Bulk 4,5 & 89334-36 & $89346-48$ & 89352-54 & $89340-42$ & \\
\hline Bulk 1,2,3 <75um & $89375-76$ & $89379-80$ & 89383-84 & $89371-72$ & \\
\hline Bulk 1,2,3 >75um & $89377-78$ & $89381-82$ & $89385-86$ & 89373-74 & \\
\hline Bulk 1,2,3 >2.0 sp.gr. & 89729 & 89725 & 89727 & 89723 & \\
\hline Bulk 1,2,3 <2.0 sp.gr. & 89730 & 89726 & 89728 & 89724 & \\
\hline Wastewater & & 96653 & & 96652 & \\
\hline
\end{tabular}




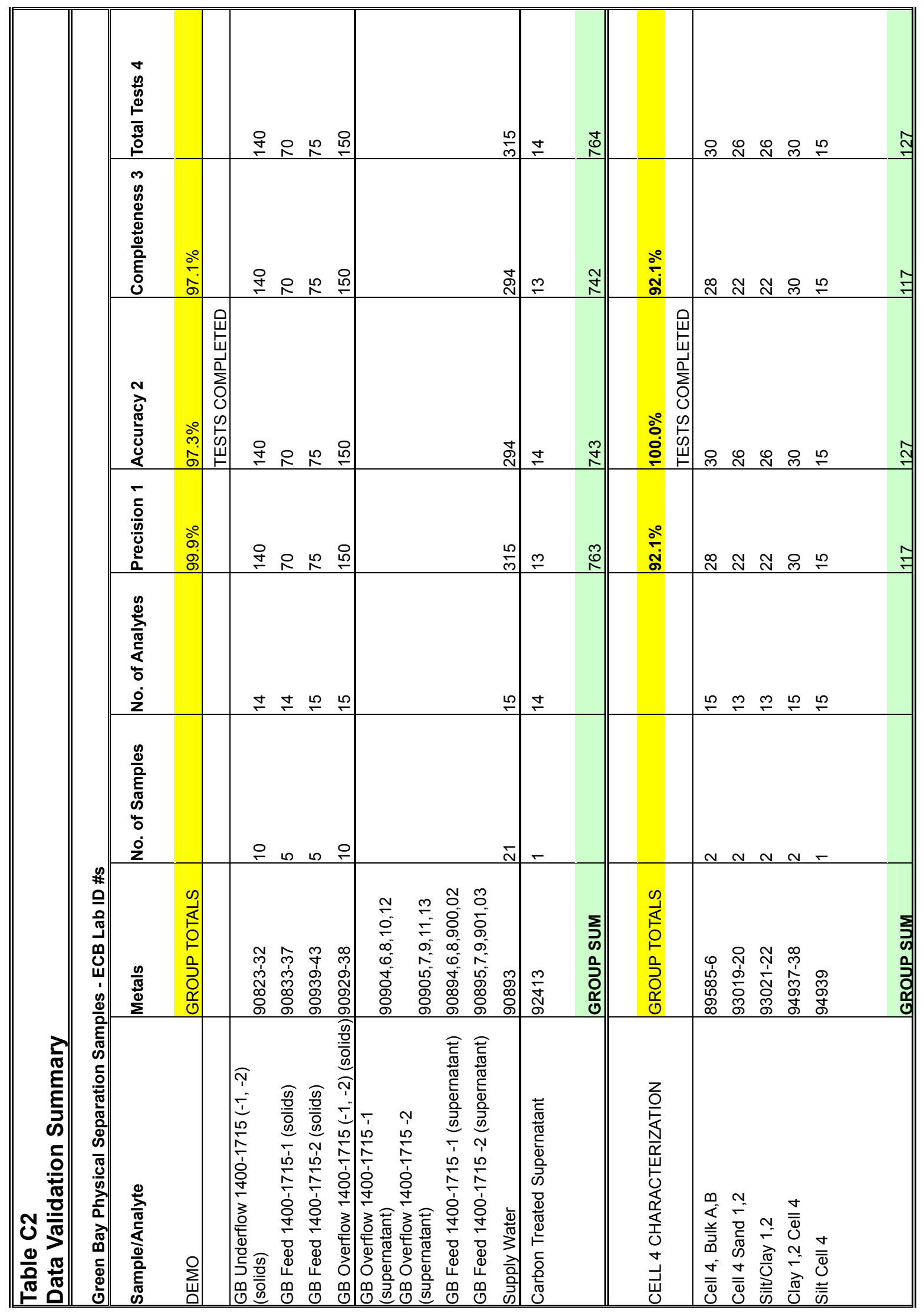




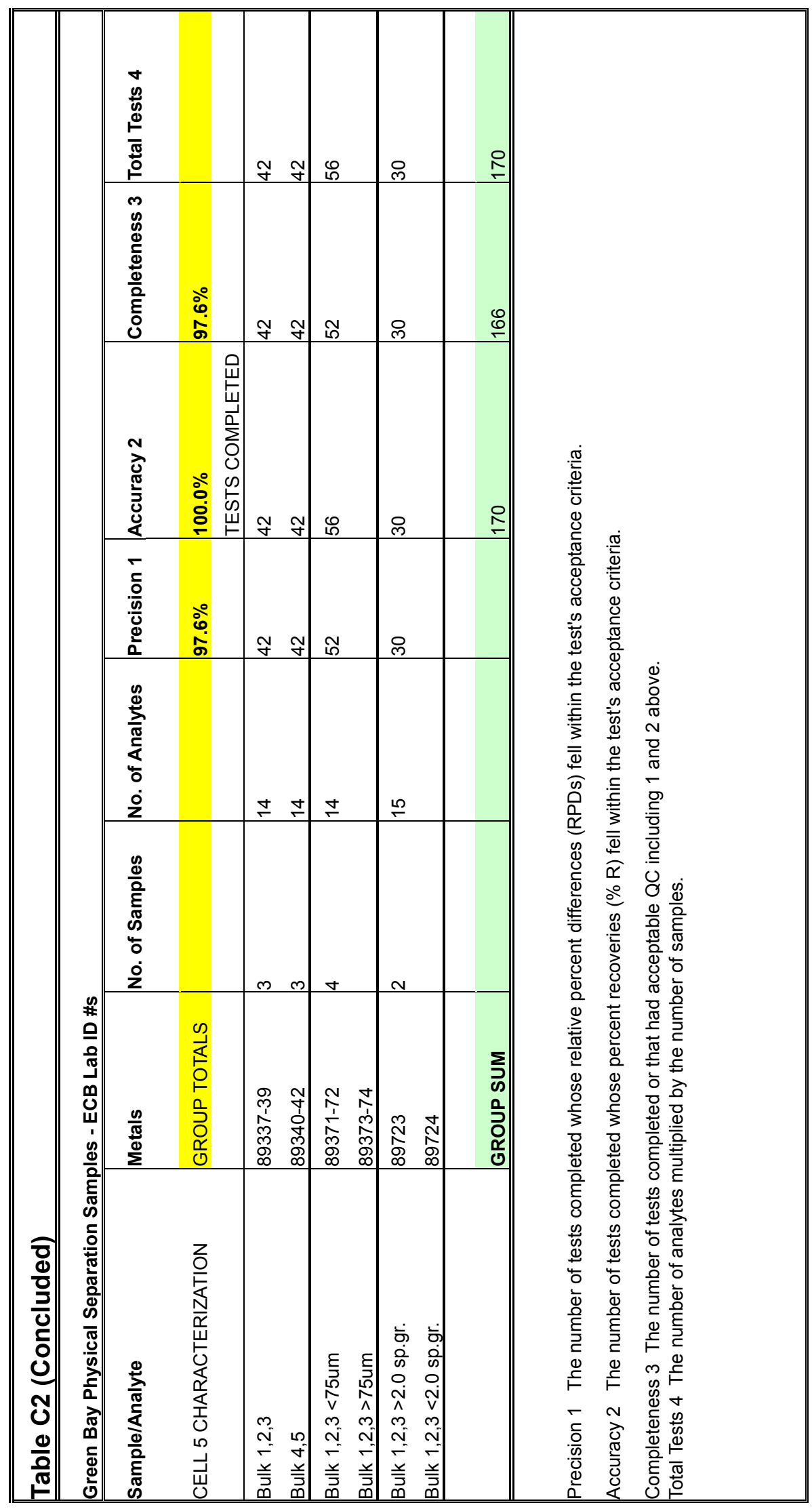




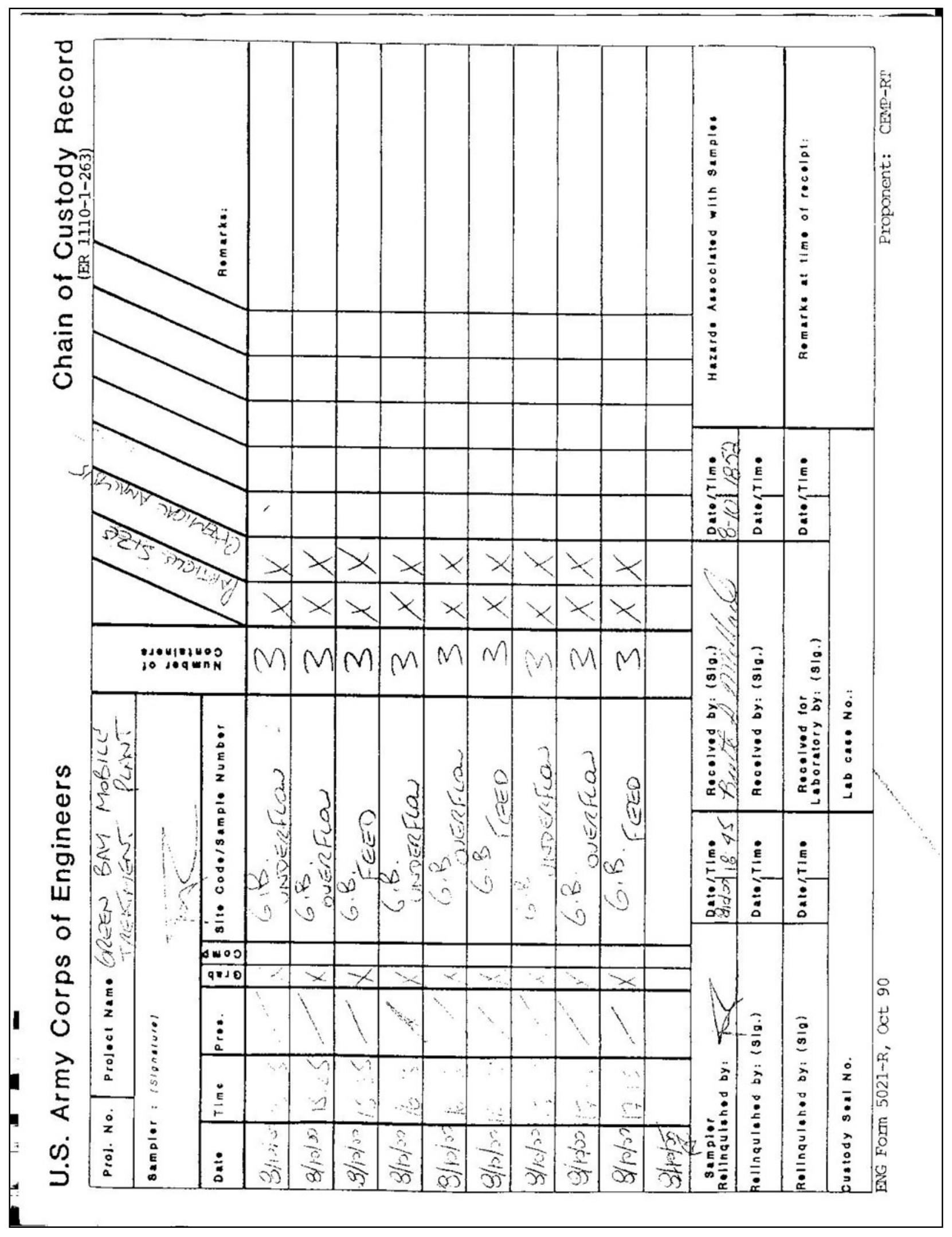




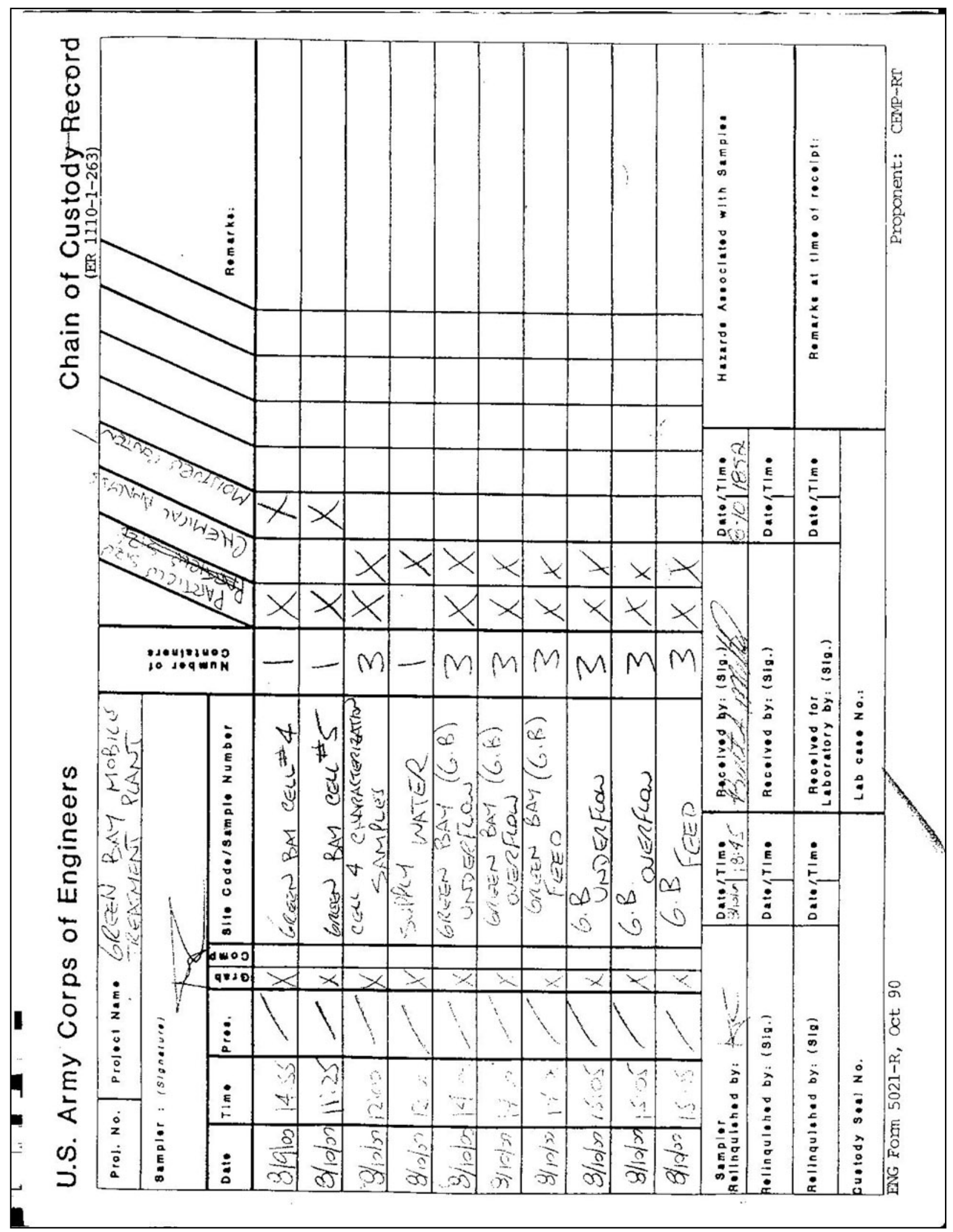




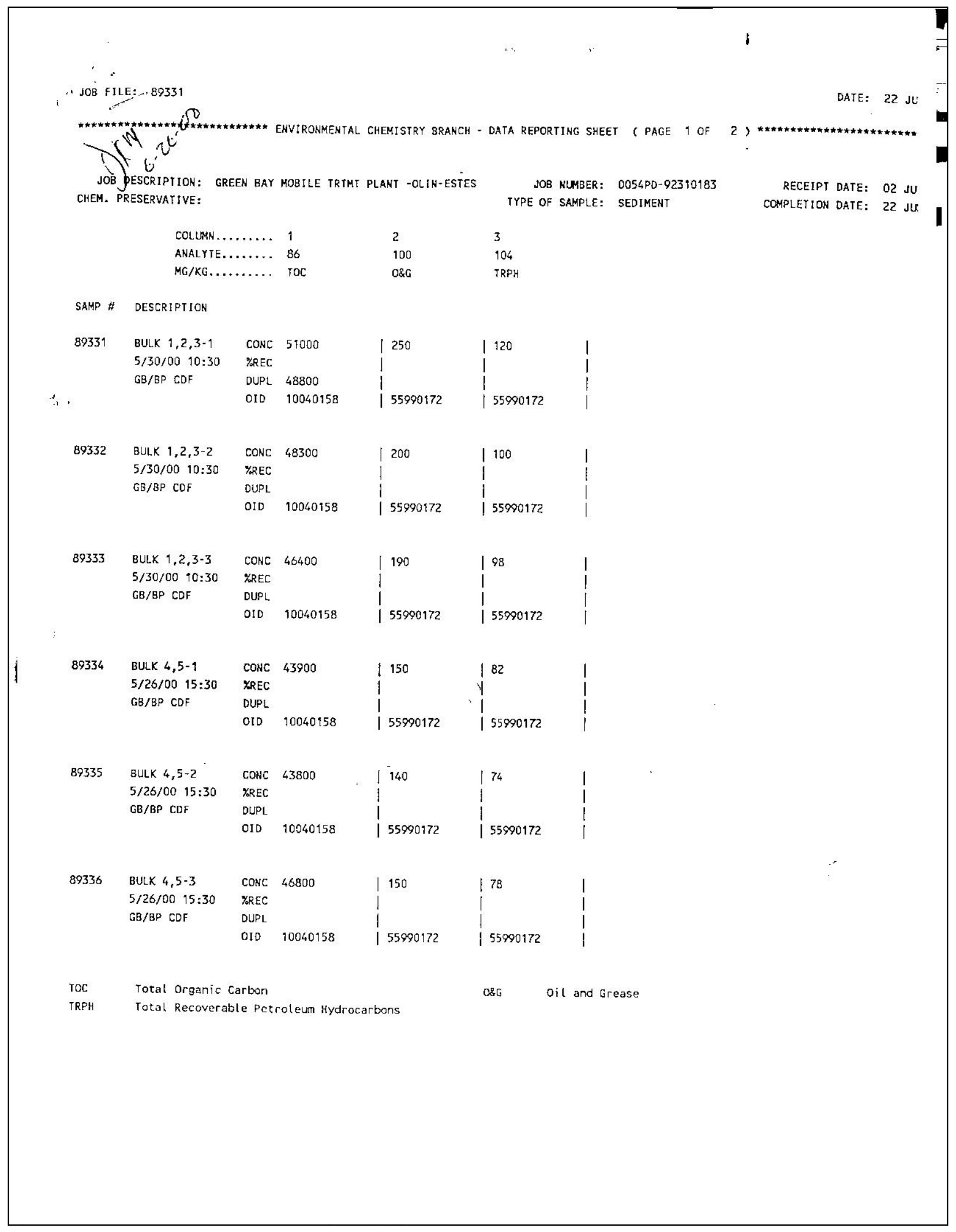




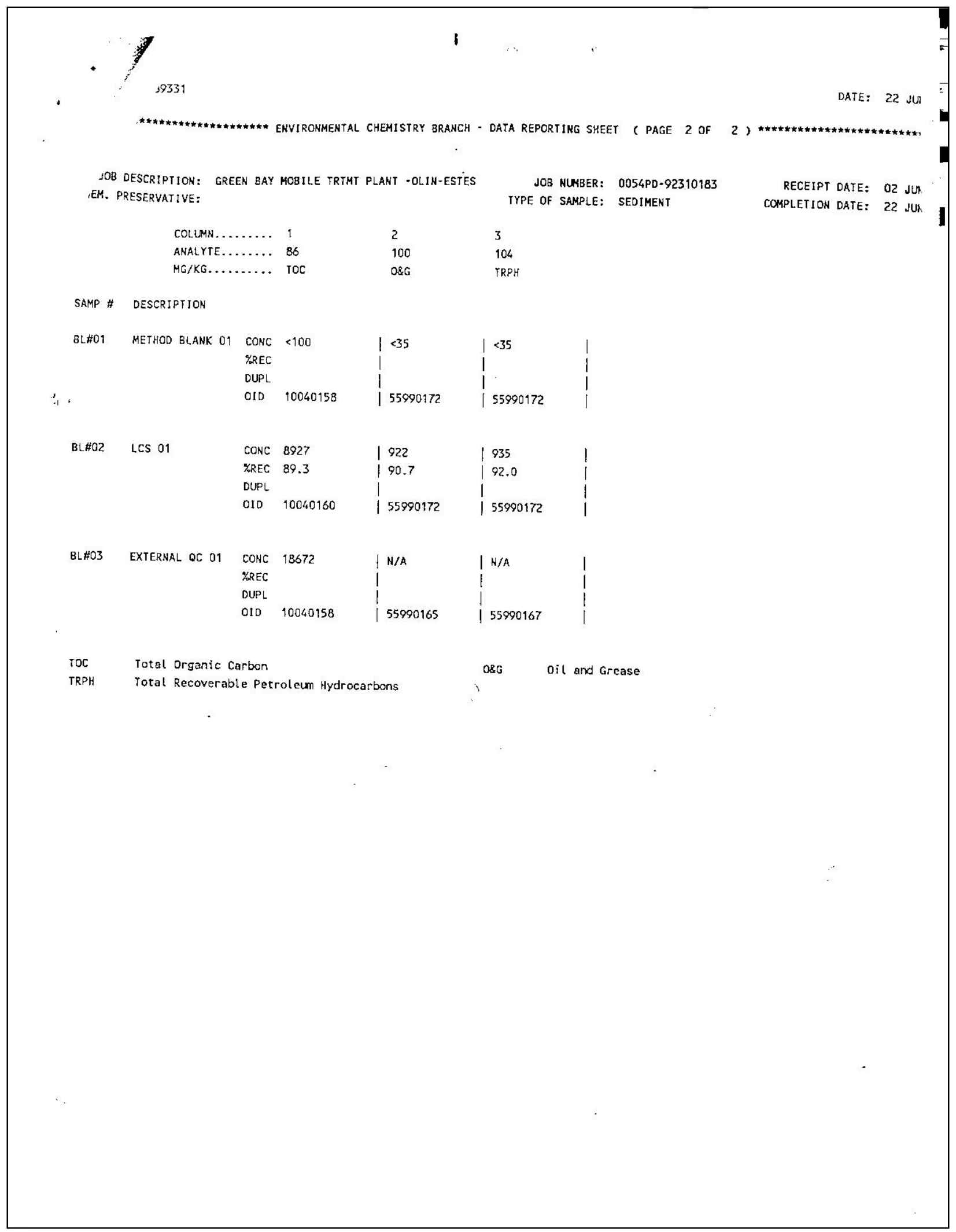




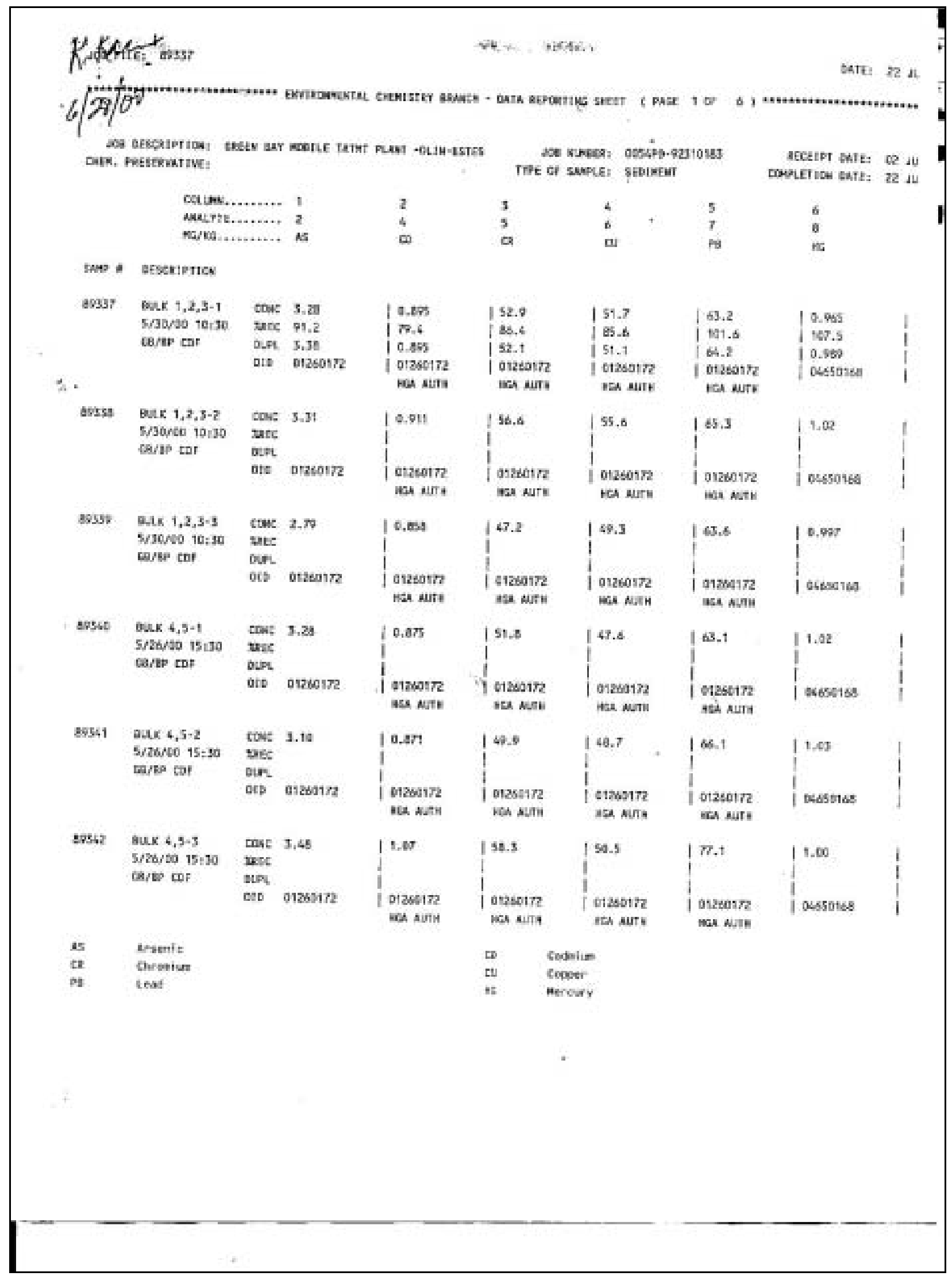




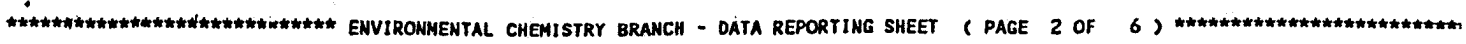

JOB DESCRIPTION: GREEN BAY MOBILE TRTMT PLANT -OLIN-ESTES CHEM. PRESERVATIVE:

$$
\begin{aligned}
& \text { COLUHA......... } 1 \\
& \text { ANALYYTE....... } 2 \\
& \text { MG/KG......... AS }
\end{aligned}
$$

SAMP \# DESCRIPTION

BL\#01

METHOD BLANK 01 CONC $<0.200$

$$
\begin{array}{ll}
\text { XREC } & \\
\text { DUPL } & \\
\text { O10 } & 01260172
\end{array}
$$

BL\#02 LCS 01

\begin{tabular}{ll|l} 
CONC & 4.30 & 2.40 \\
XREC & 86.0 & 100.4 \\
OUPL & & \\
OID & 01260172 & $\begin{array}{l}01260172 \\
\text { HGA AUTH }\end{array}$
\end{tabular}

BL\#03 EXTERNAL OC 01
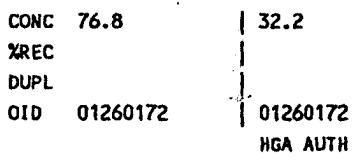

AS Arsenic

CR Chromiun

PB Lead

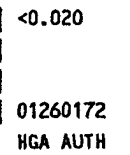

JOB NUMBER: OOS4PD-92310183 TYPE OF SAMPLE: SEDIMENT

RECEIPT DATE: 02 JUN COMPLETION DATE: $22 \mathrm{JUW}$

$$
\begin{aligned}
& 6 \\
& 8 \\
& \text { HG }
\end{aligned}
$$

R
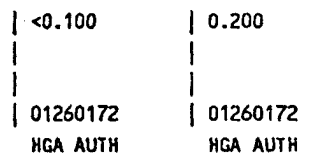

$\left\{\begin{array}{l}<0.100 \\ 01260172 \\ \text { HGA AUTH }\end{array}\right.$

$1<0.040$

1

04650168

19.90

99.1

1

109260172

HGA AUTH

10.2

102.0

101

$\begin{array}{ll}01260172 & 01260172 \\ \text { HGA AUTH } & \text { HGA AUTH }\end{array}$

0.0757

5.80

116.8

100.9

| 04650168
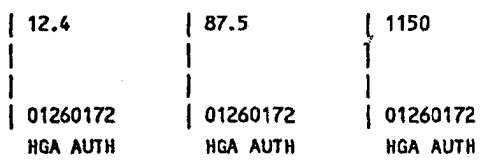

10.050

04650168

$\begin{array}{ll}\text { CD } & \text { Cadnium } \\ \text { CU } & \text { Copper } \\ \text { i) } & \text { Mercury }\end{array}$




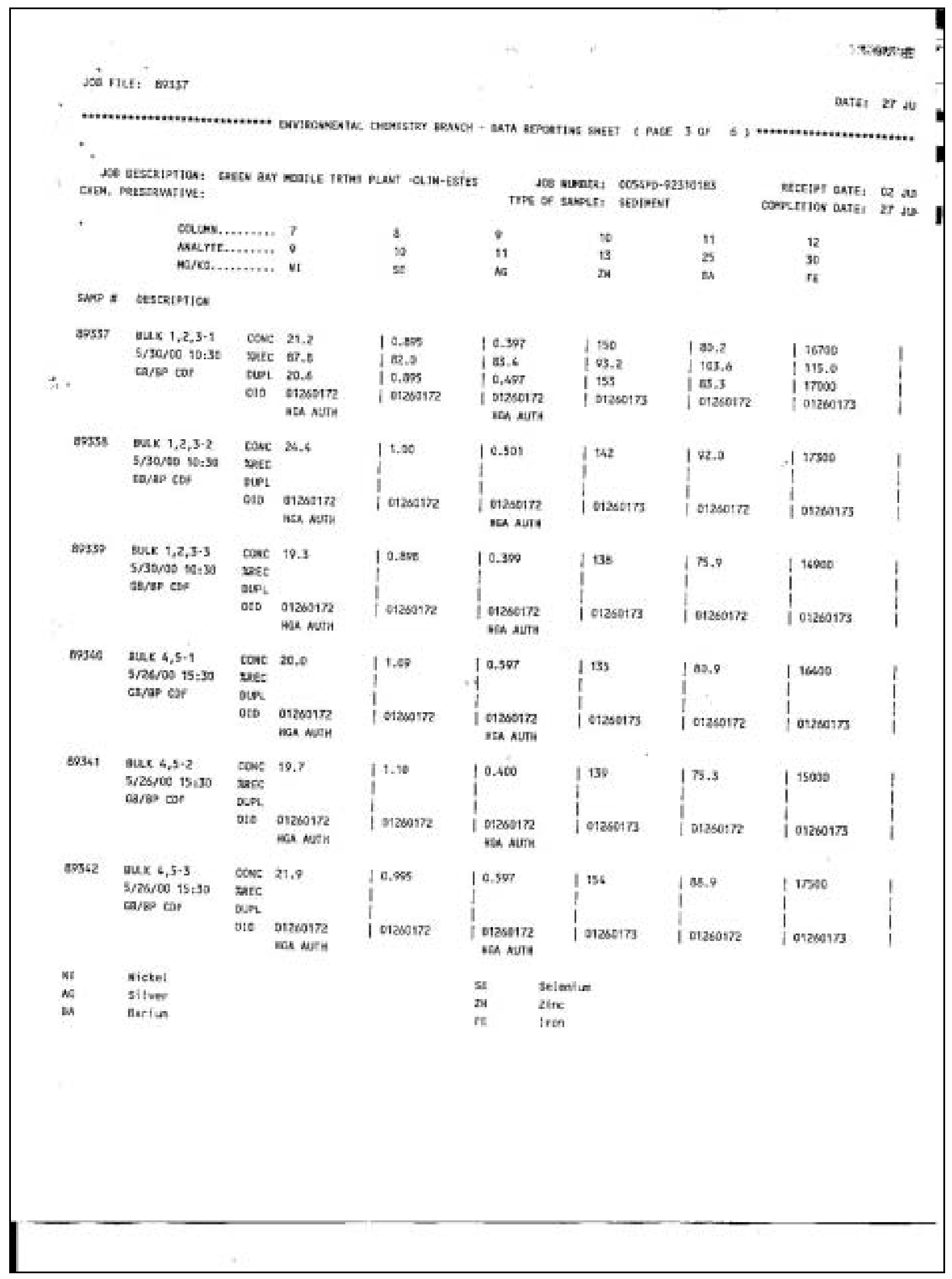




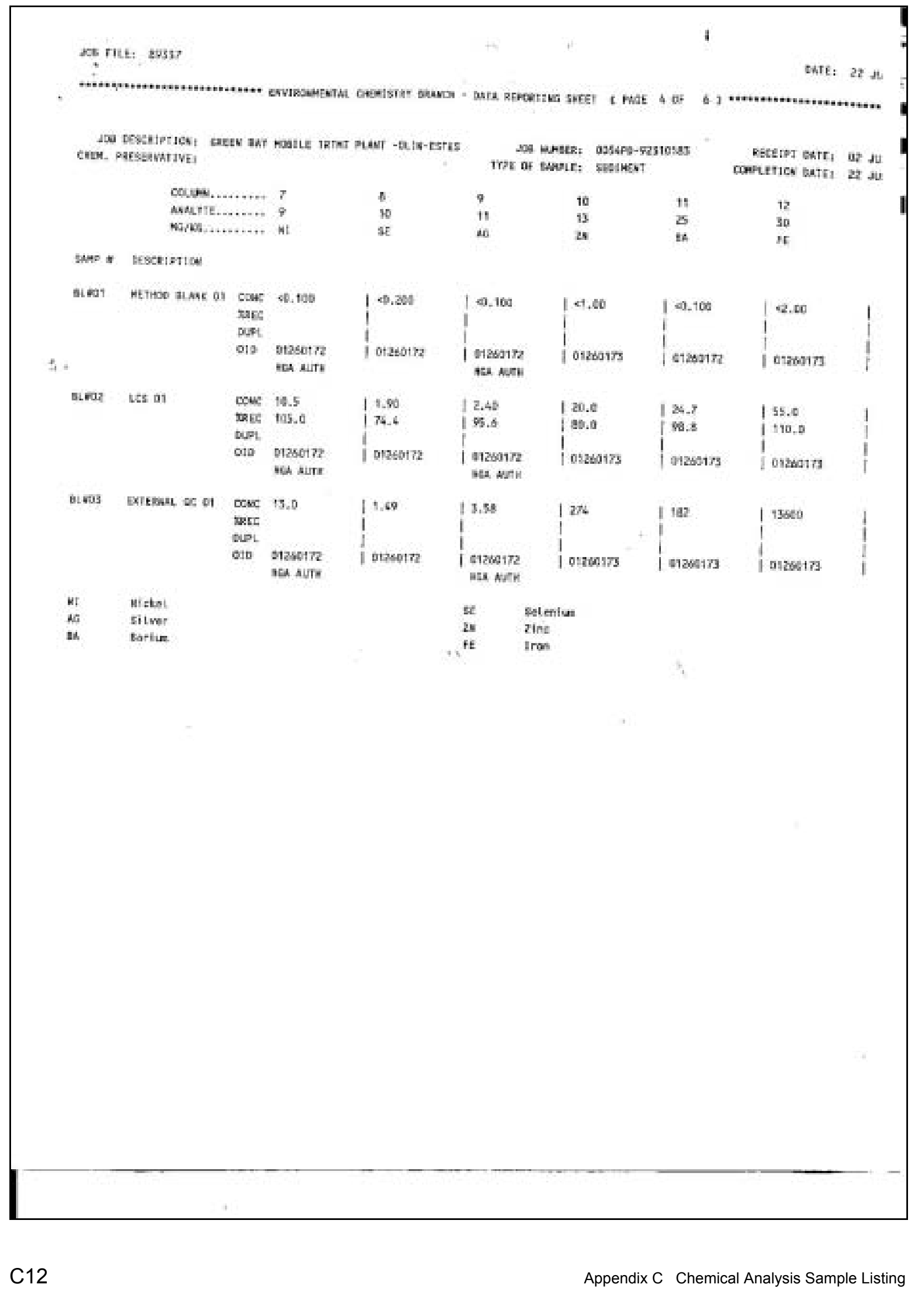




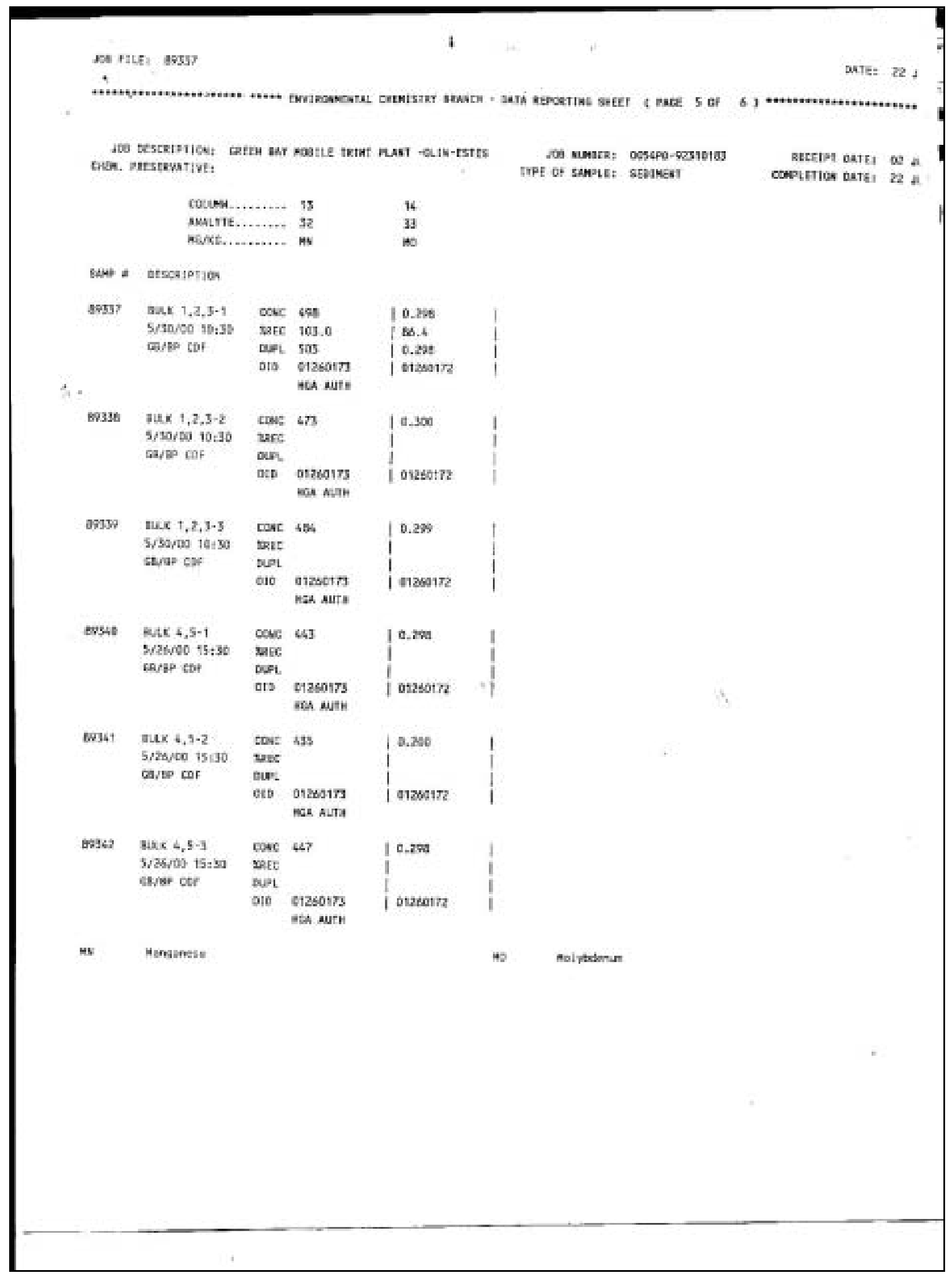




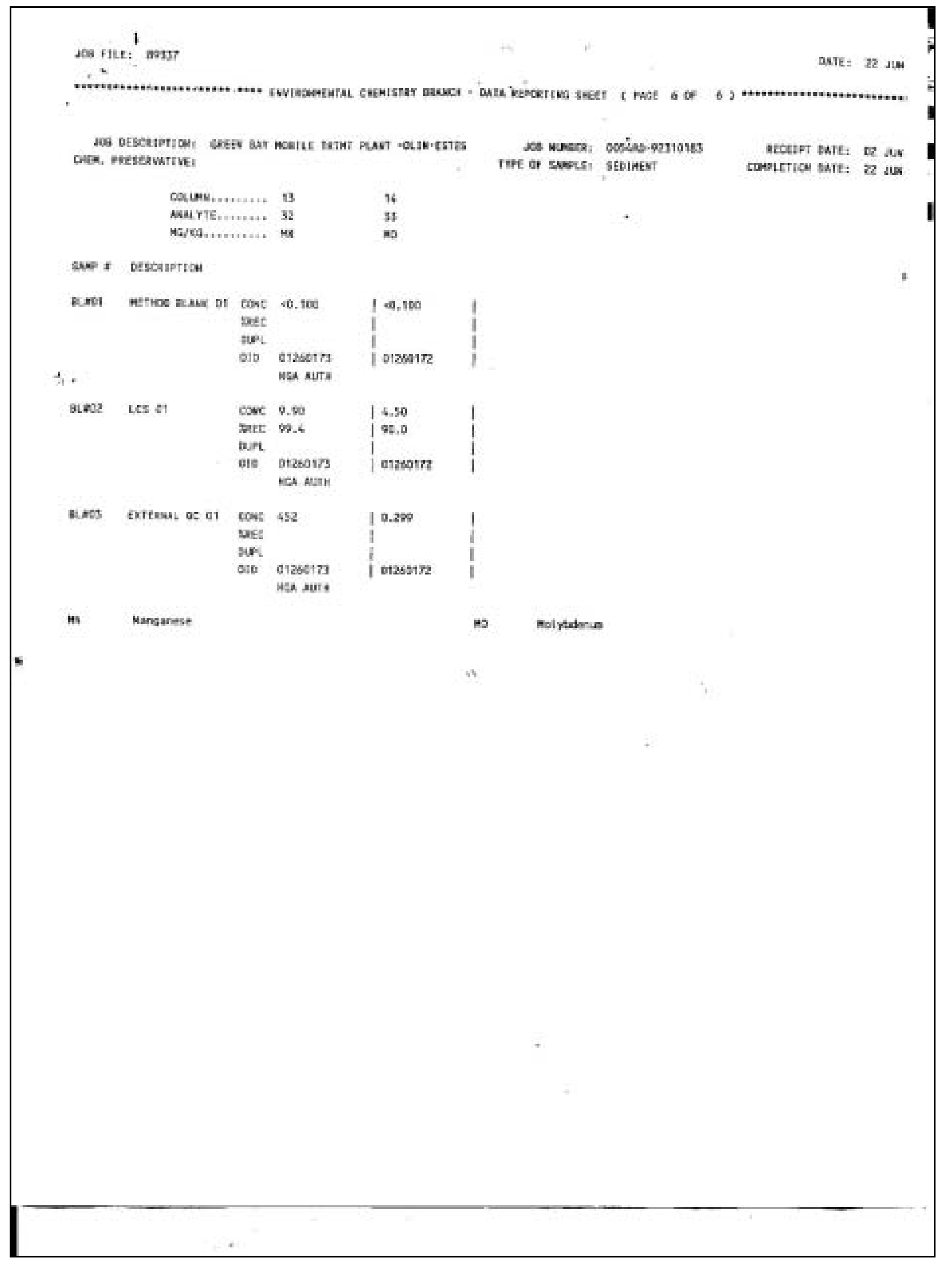




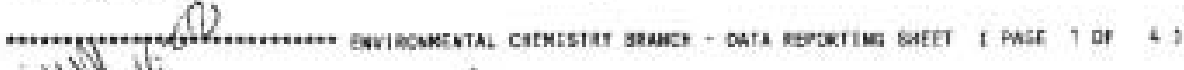

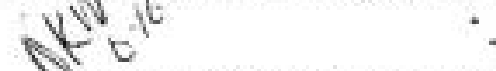

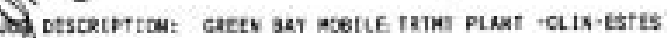
DEE. Fetsranktrvet

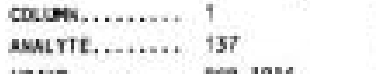

uG/KE........... PCa-1016

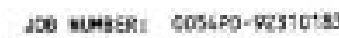
TYPE be saHLE: SEOHEST

EcEipt Darez az JW 6 contion bute: is fiv :

34

$139 \quad 960$

pcs- $+232 \quad+08-1262$

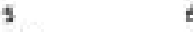

$161+142$

pco-1264 pca-12S4

Sup ; DEsERTPTIC

asyu bux $1,2,3$, $5 / 30,00070+30$ Caree cor

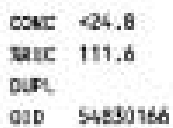

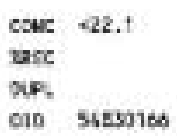

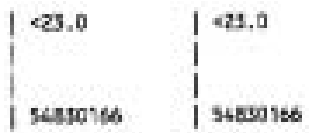
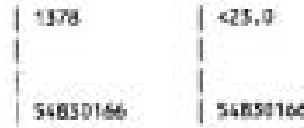

1.25 .0

I

1

I suasotso
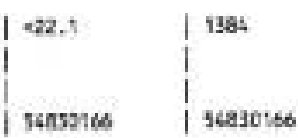

$\mid \begin{aligned} & 422.1 \\ & 56850160\end{aligned}$

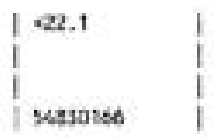

PC8-1221 $\mathrm{rCg}-1227$

7Cb-1262 PCA-124?

DtE-1254 FCS-1256

5 , $50-1016$

Rat-1232 pas-1232

pCa-t248 pos-1248

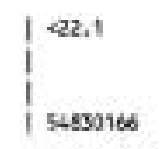

1 54s 


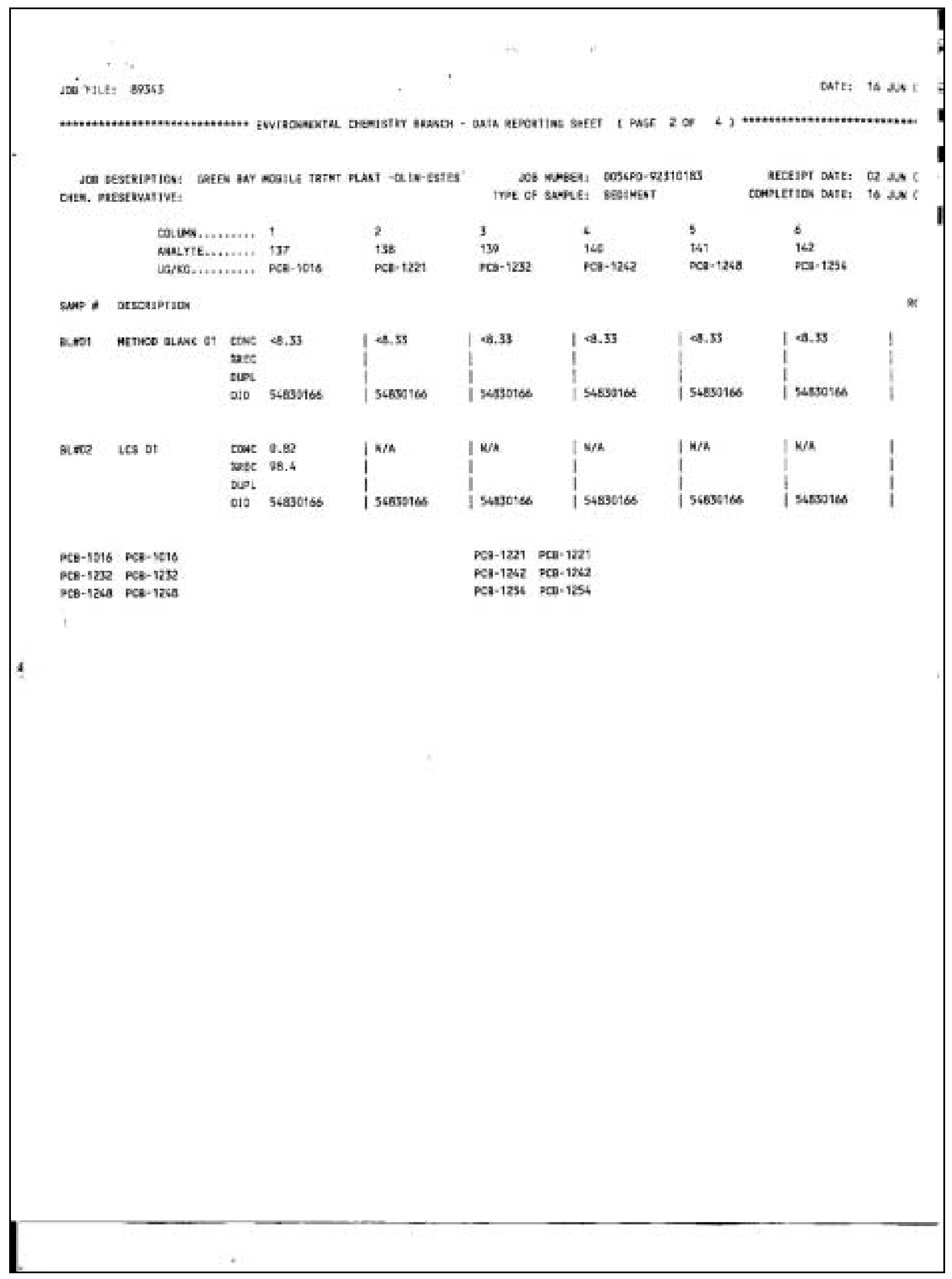




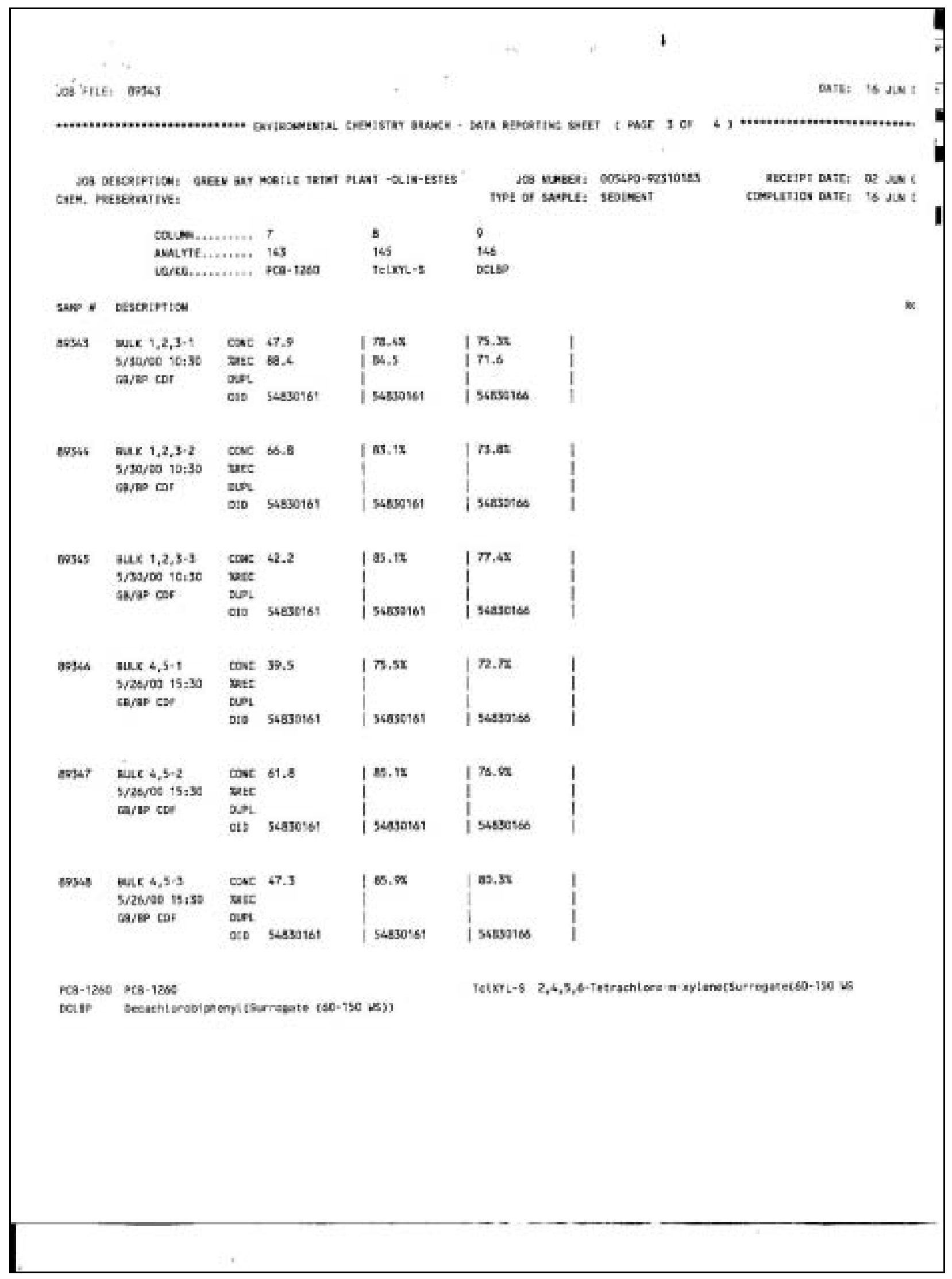




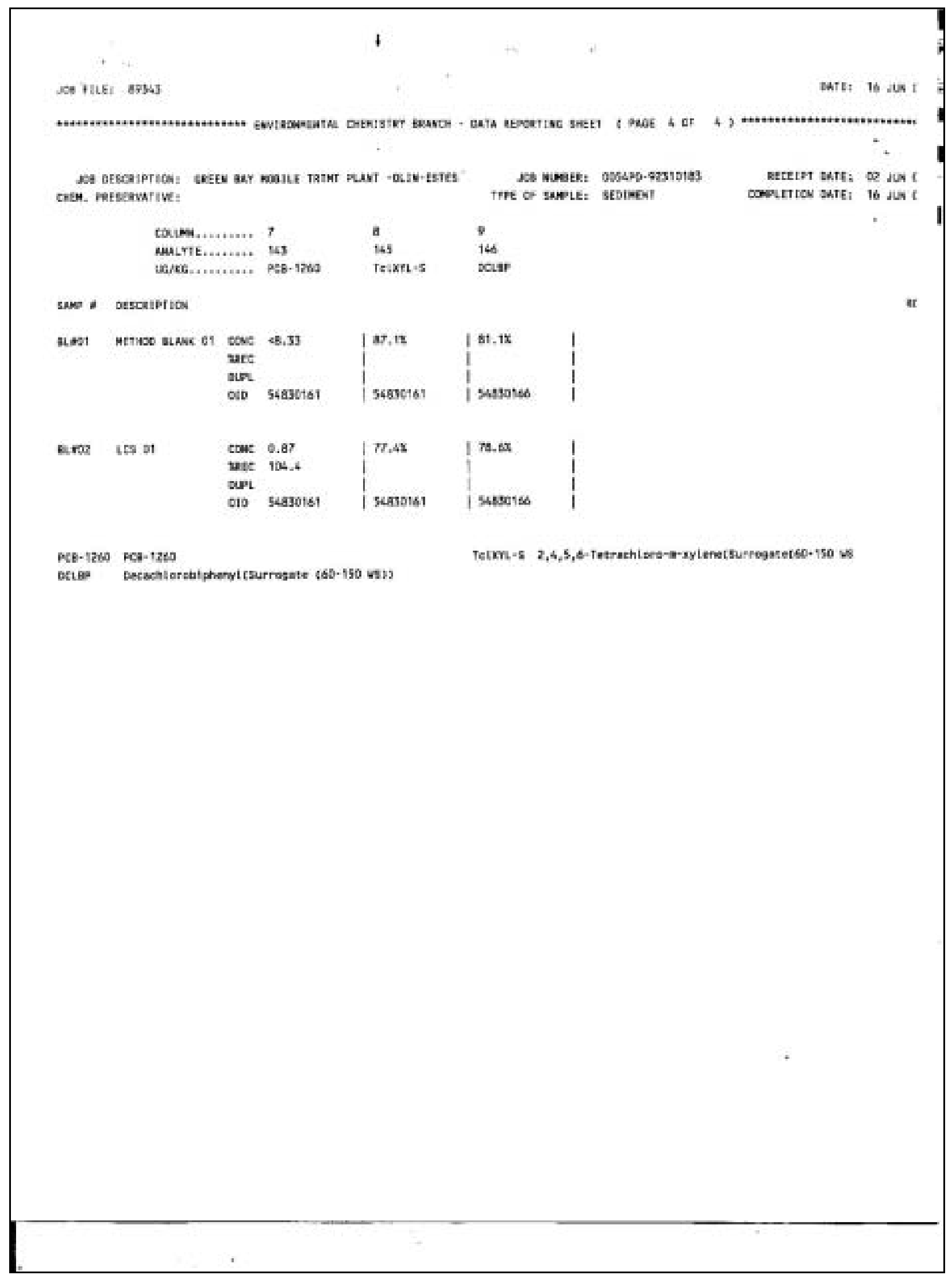




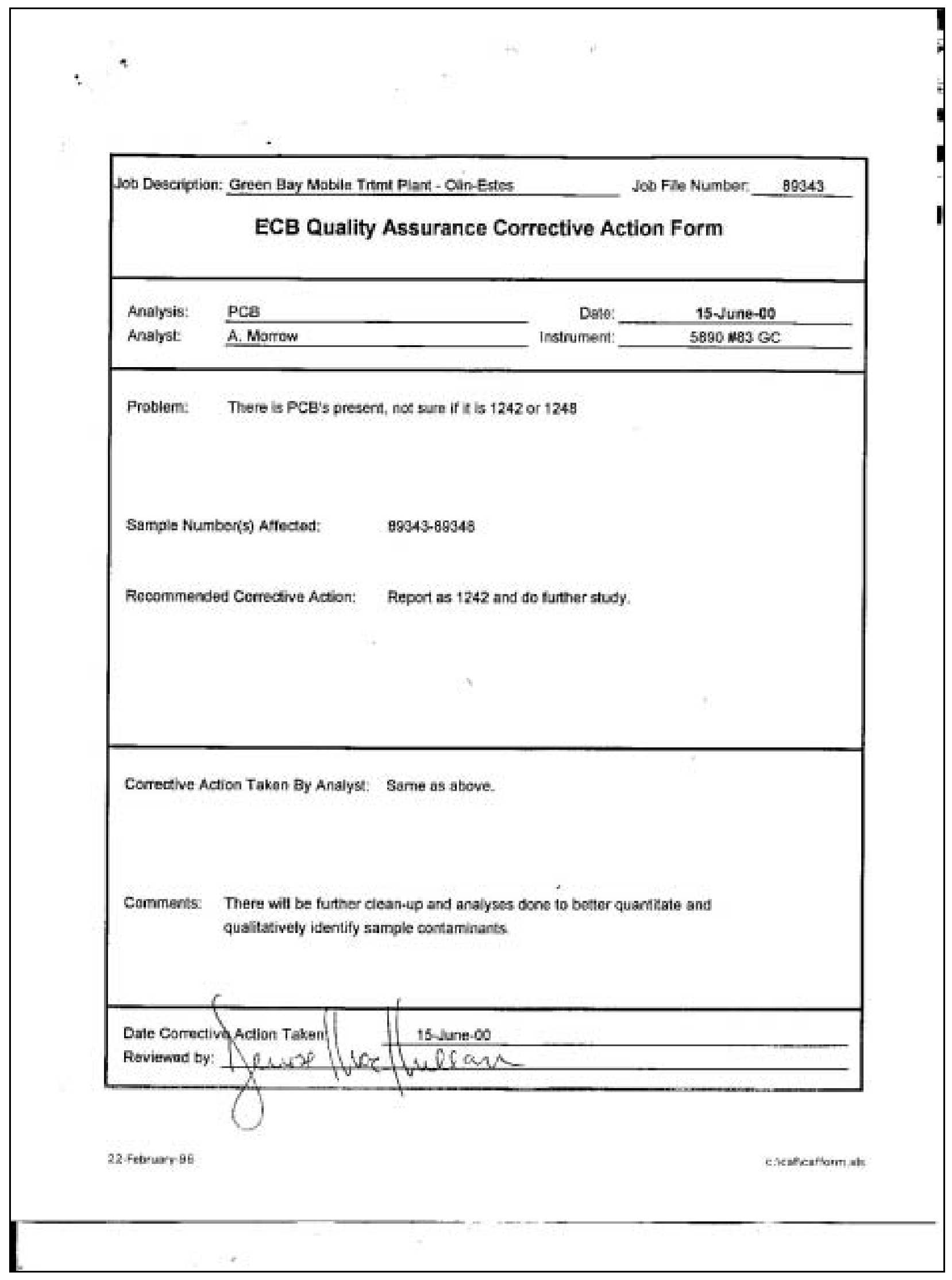




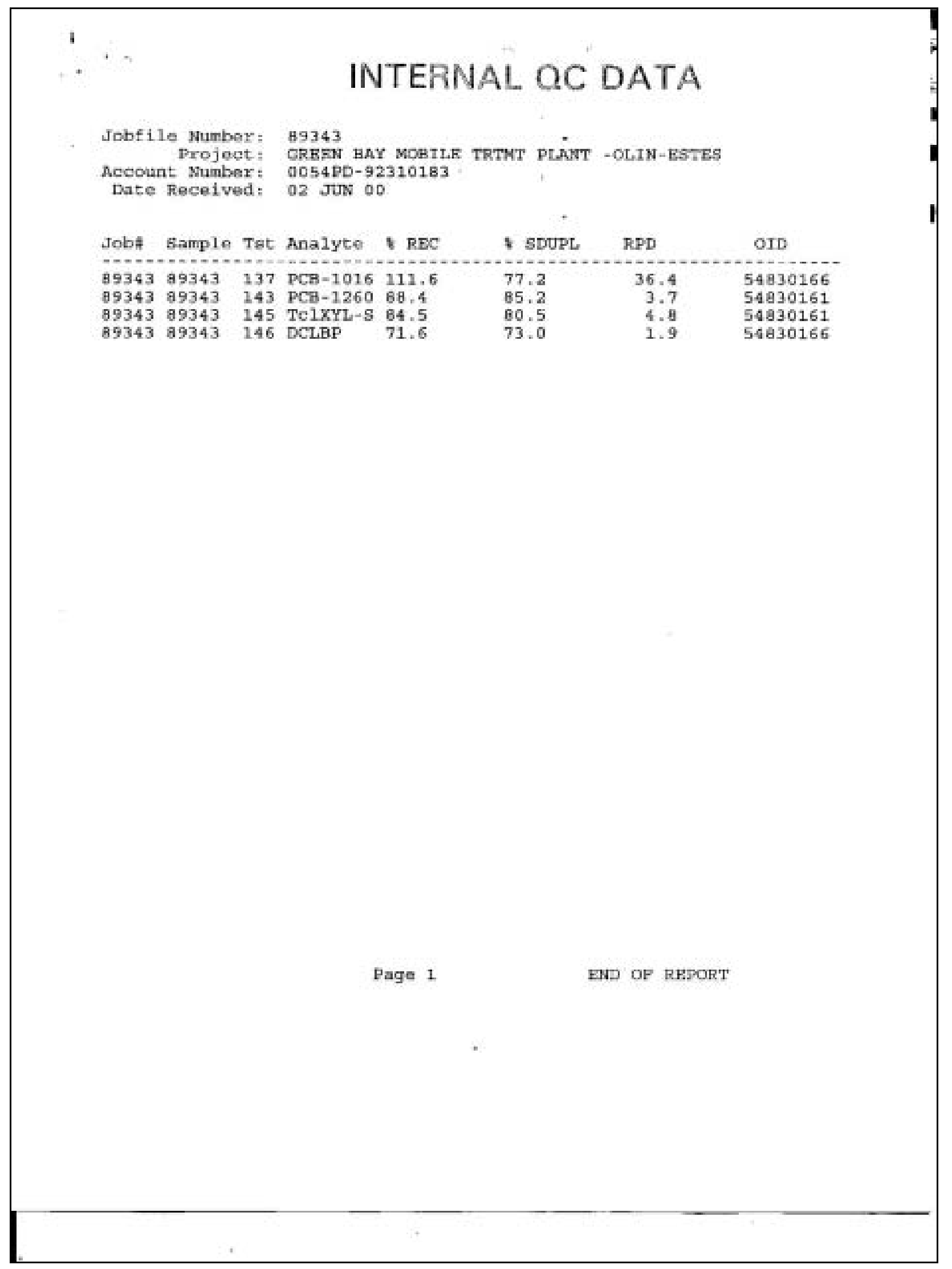




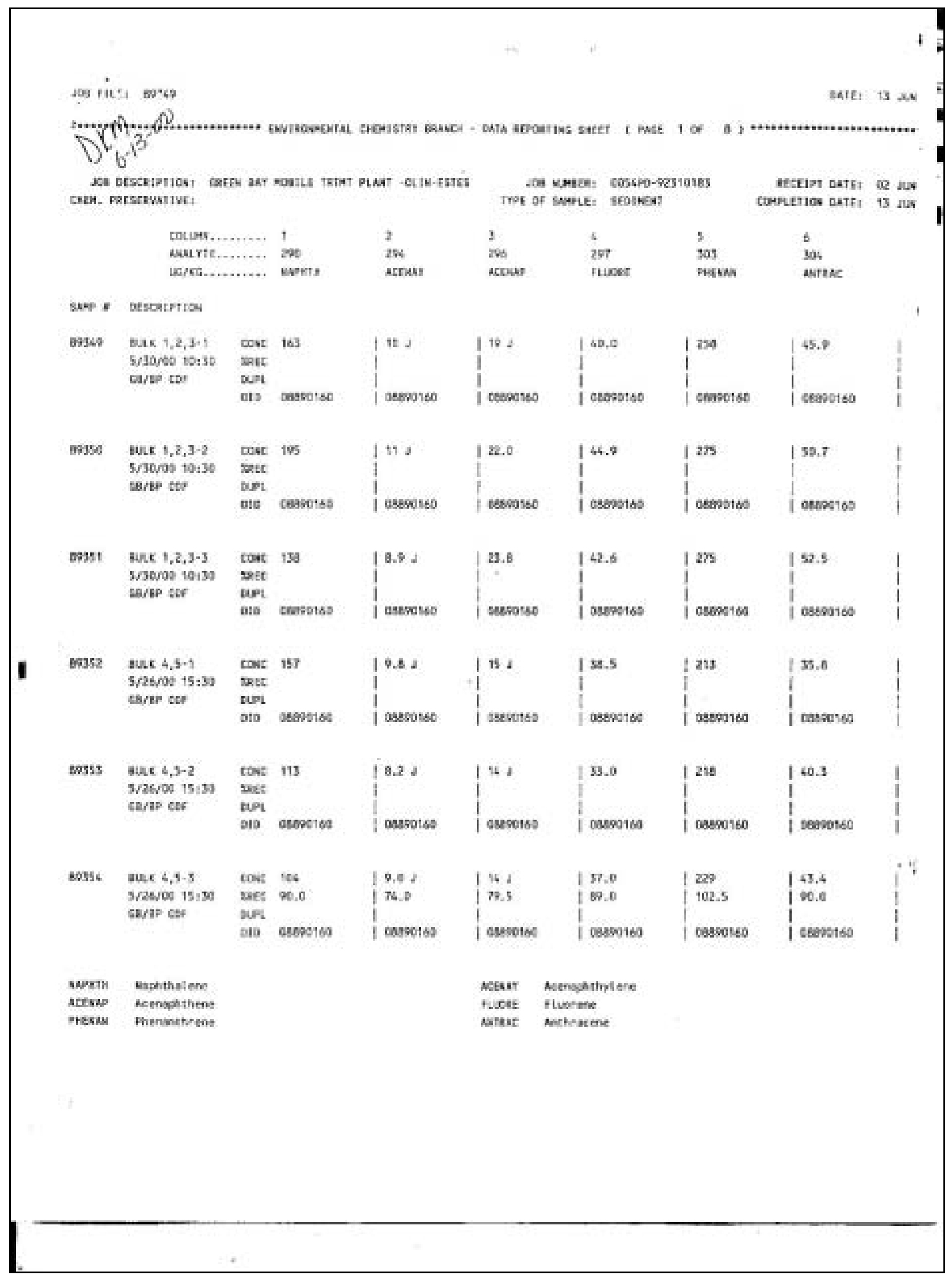




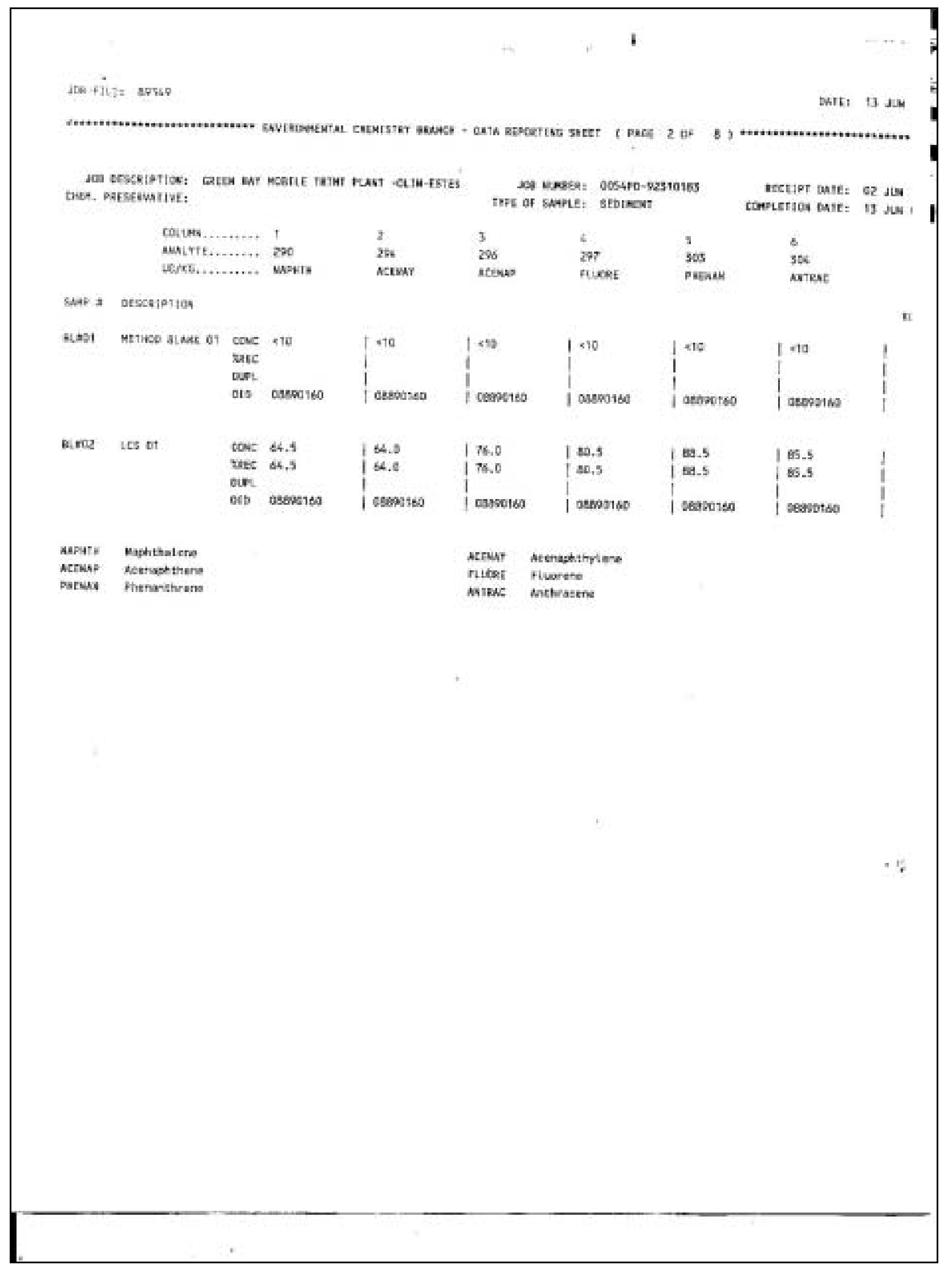


at itit: asus

taret is as

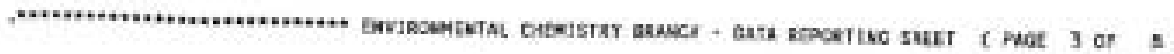

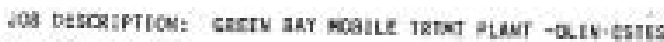
DHFW, Nesrowative:

J90 unate: Des4p2-92310183

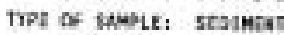

tectert Dure: De dus

couss...........

MATrFE........ $\$ 56$

3

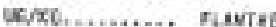

7.

35

$10 \quad 11$

Prage

otrst austre

313

Barlatis

COMELETIOW OR.TE 13 asi

sann a otcasprias

BS16 BuL $1,2,1+1$

$5 / 36,02010,30$

wart.

tersp cte

DSOL

aI2 censotes

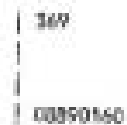

1253

i

I cassosso

i ceanses

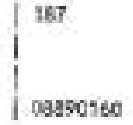

i res

147

31.6

Baso nute $5,2,3-2$ couc sas

5/3500 10:30 viec

carar car bor

010 ckanoles

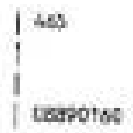

$12 n$

i

t cosonuse

I 297

teanotos

ต915) wi:x $1,2,3-3$

csve 35s

$0=30$ DEEC

carap cer

DEC
DUP

밍 sesentos

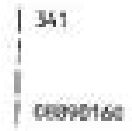

1218

i

i seenotse

$\left.\right|_{\text {ceavotso }} ^{257}$

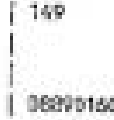

| tos

I

60352 Bure 4,5-1.

$5 / 25, / 6015,50$

$\operatorname{cosc} 2 x s$

abar car

tubi

ofo asmovios

$\left\{\begin{array}{l}2 x \\ \text { indeses }\end{array}\right.$

I 100

i

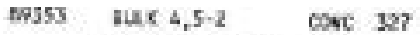

$5 / 20600015=30$

sate

IUP

이 6360160

$\left.\right|_{10000} ^{1000}$

$\left.\right|_{\text {eseno:os }} ^{105}$

$\left\{\begin{array}{l}\text { in . } \\ \text { assoser }\end{array}\right.$

$\sum_{\text {ac0ss }}^{125}$

197.6

tosionatos

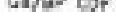

$\operatorname{cosic} 304$

sosse siax 6,5-5

5/24/00 15:30

sate 130.0

Aupi

as 0350160

1305
130.0
100000160

193

I 11.

I

$\left.\right|_{160} ^{168}$

$\left.\right|_{128} ^{128}$

1163

i

I ascosiso

HAVTAE Pluoranthen

carse chryene

aspuar aenzotbufluarantrene

Pnest Prrere

Beuraz Beruscasarthracene

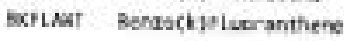


i

jप̣ Filici asso

catr: is JN

n.t.n.w. .

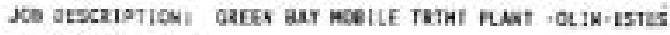

J9A Grate: 0054pQ-923)

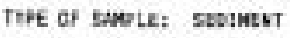

BFCEIPf bate: O2 Jis CиE. Patstavatrif:
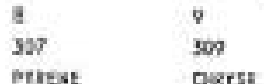

$\begin{array}{ll}10 & 11 \\ 359 & 313 \\ \text { Bautret } & \text { IerLant }\end{array}$
COAPLETIOS DAFE; 13 JuM

\begin{tabular}{|c|c|}
\hline cocues, . .,..., & 7 \\
\hline AractTe, & 386 \\
\hline G/ng ............ & Ftautes \\
\hline
\end{tabular}

coverst

Basto:

IอrLakT

12

akfunt

wap $x$ bescatprad

atart netsos alaue as cowe eso

प्रत5

D.PI

arp corgorso

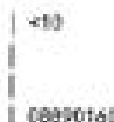

170

i

ceasotas I estiones

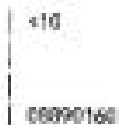

$1=10$

i

| cospares

elp

I

nescotse

ntegr ces ot

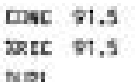

I 87.0

87.0

107.5

19.5

do eseasias | coposica

1

assetoc

$\mid \begin{aligned} & \text { as, } 0 \\ & \text { as, }\end{aligned}$
I aseonico

78.5
70.5
1 cas9oses

108,9

at, 0

I

| cospoiea |

rustar Fluprenthere

Darst Dirvene

MTEst mrone

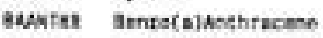

akcus? Bentacklftuaranthene 
jos Tites torso

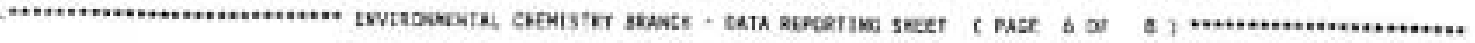

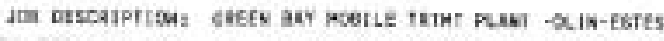
crex. sezseratrue!

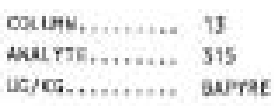

SAP $=$ Descotmich

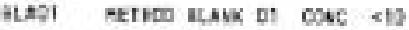

verc:

ont

ale segotso

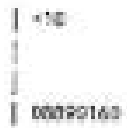

$\left\{\begin{array}{l}10 \\ 56800+56\end{array}\right.$

J89 Nunbea 0054Fo-\$2310183 TIPE CF Suptet setrext

RECEMPT SATE1 EZ MU oopleftba eaTE! [3 Ja

16
316
1725912

15

317

16

318

17

322

18

gensast

327

$2+13 p-5$

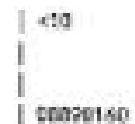

$\int_{\text {seasotos }}^{\operatorname{sic}}$

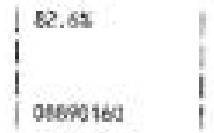

E. me? Les 41

\begin{tabular}{|c|c|c|}
\hline cous & $\pi, 5$ & | 87.0 \\
\hline use & 74,5 & | ay.n \\
\hline oust & & \\
\hline 10 & nasposes & 108500150 \\
\hline
\end{tabular}

105.5

105.5

1

| onsogse

בAPYE

Beruotewyrarw

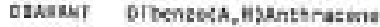

z-earen 2-Methrinaphehatens

I1zson Indene(1,2,3:t, , ojpyrene

d-tur-pr eenocts, H, tuperylens

2rtep.s 2-fluarobiphenyl(surrogate (30-115 \$) ? 


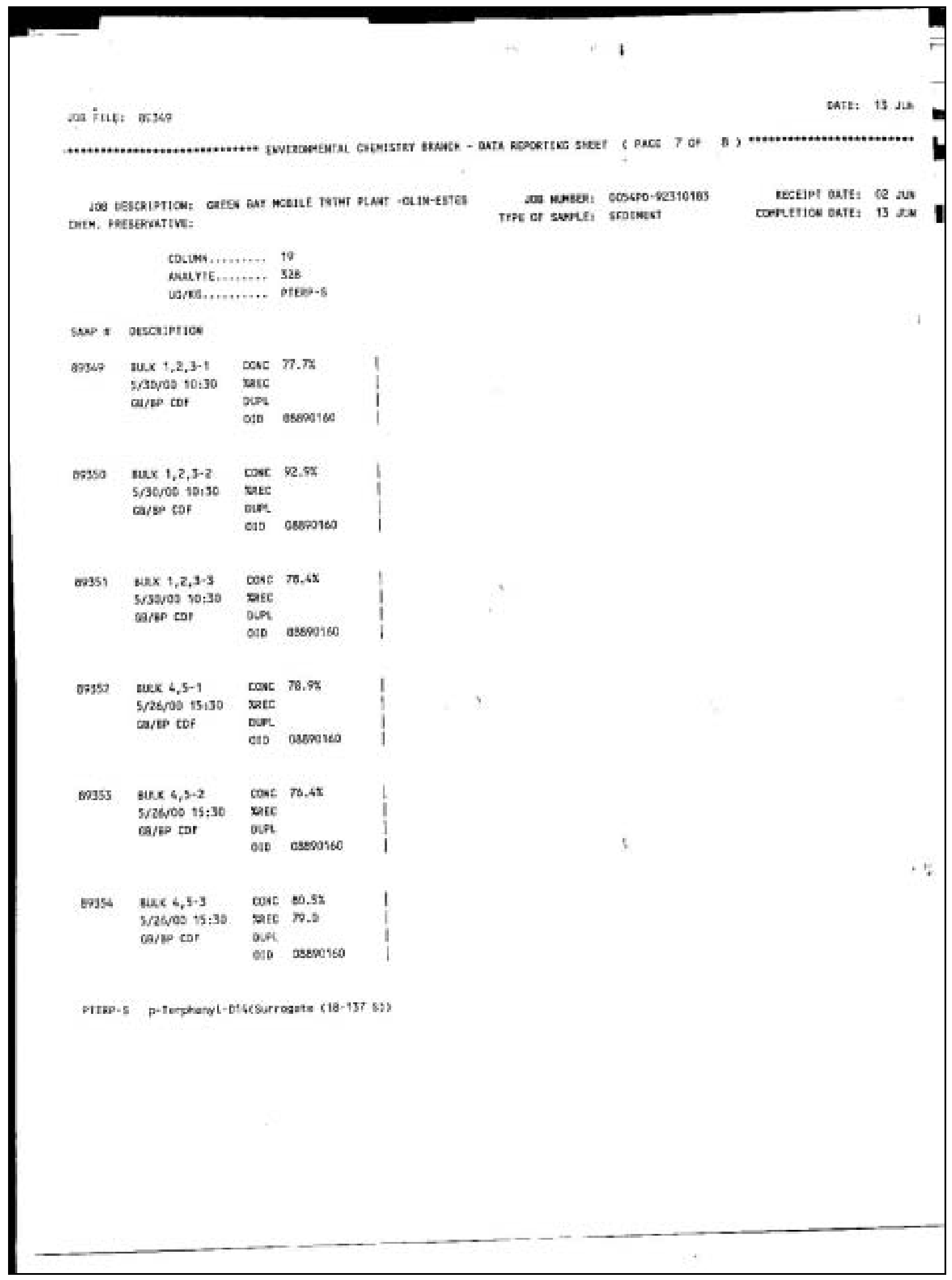




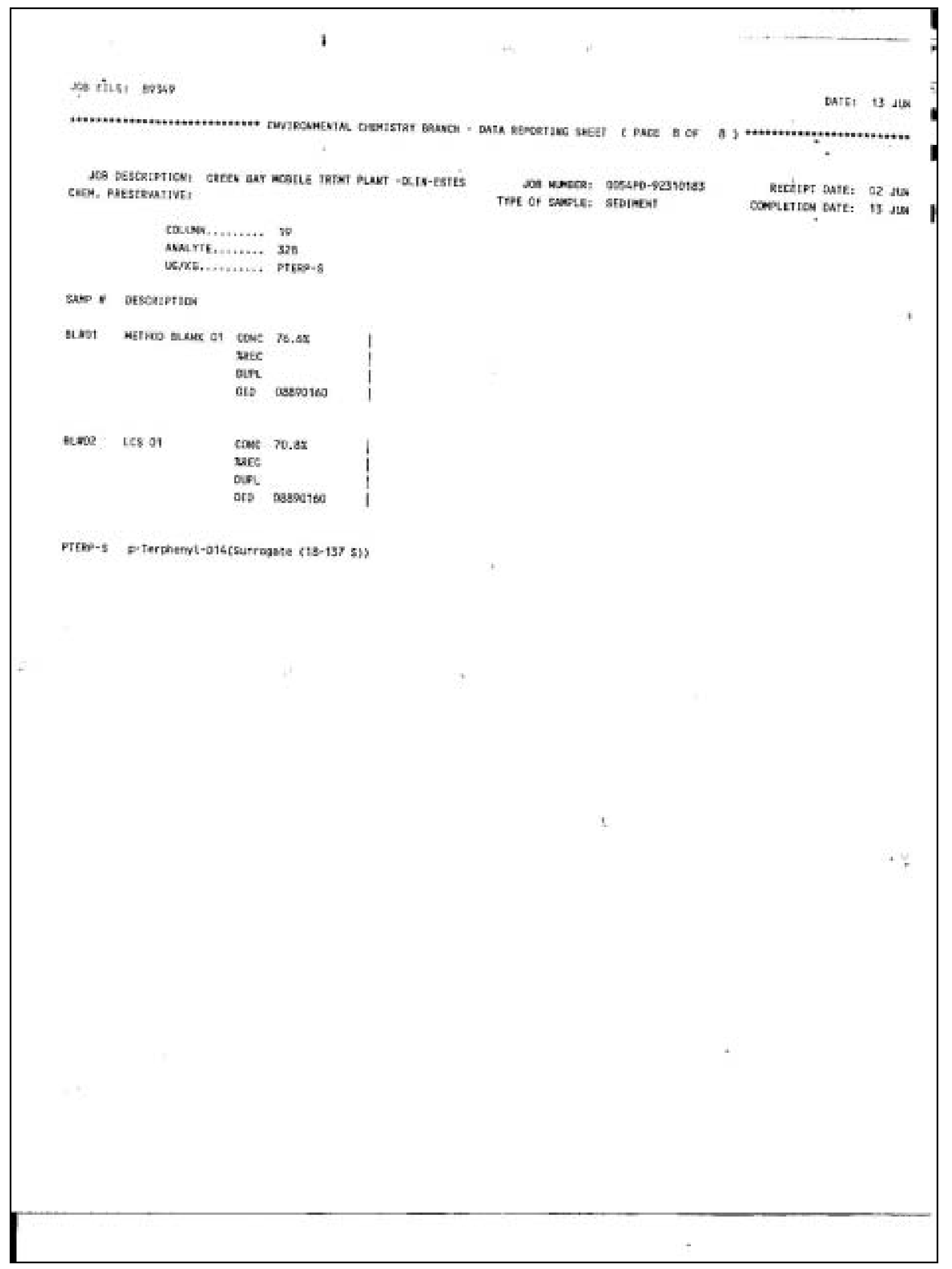




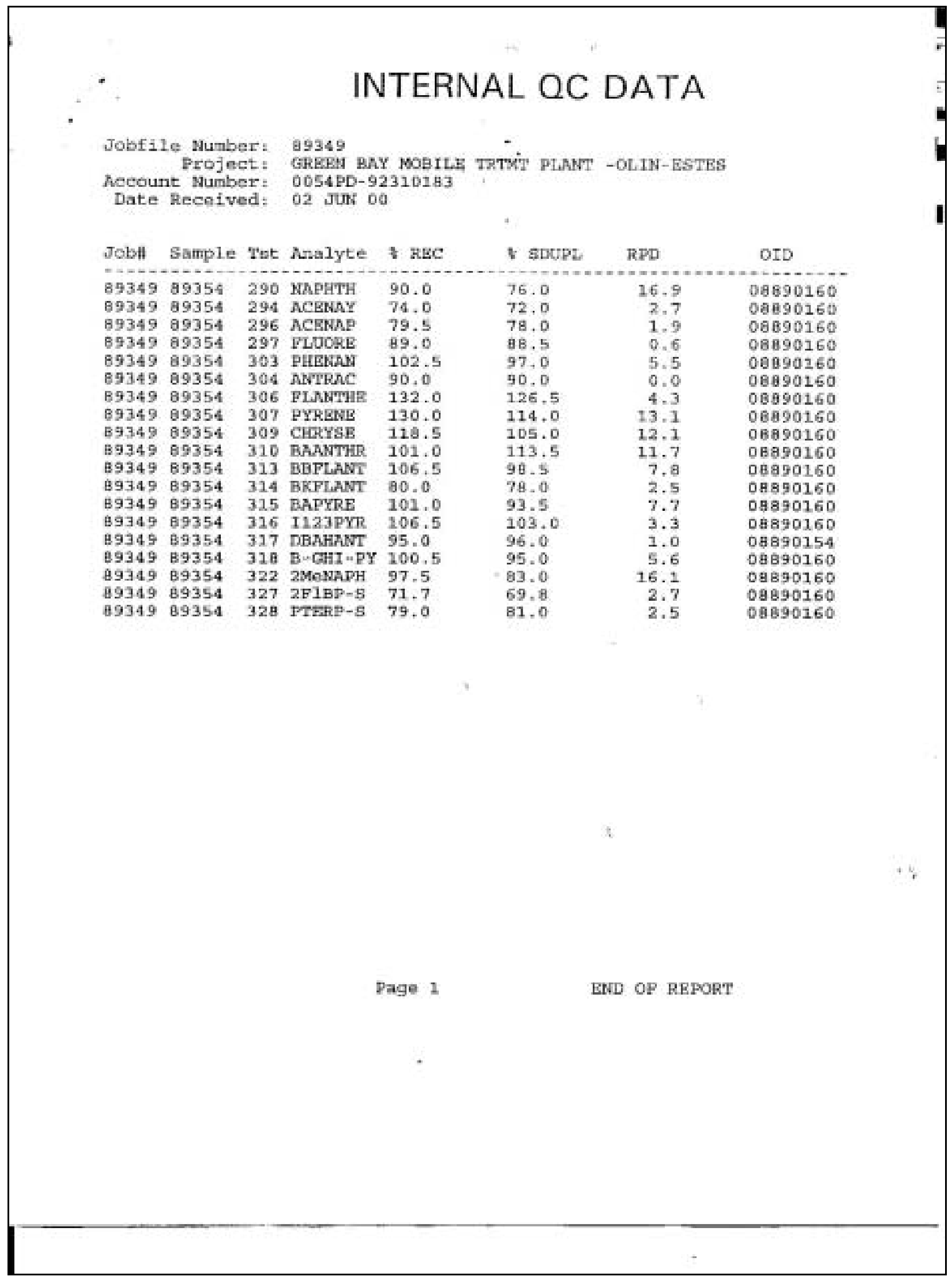




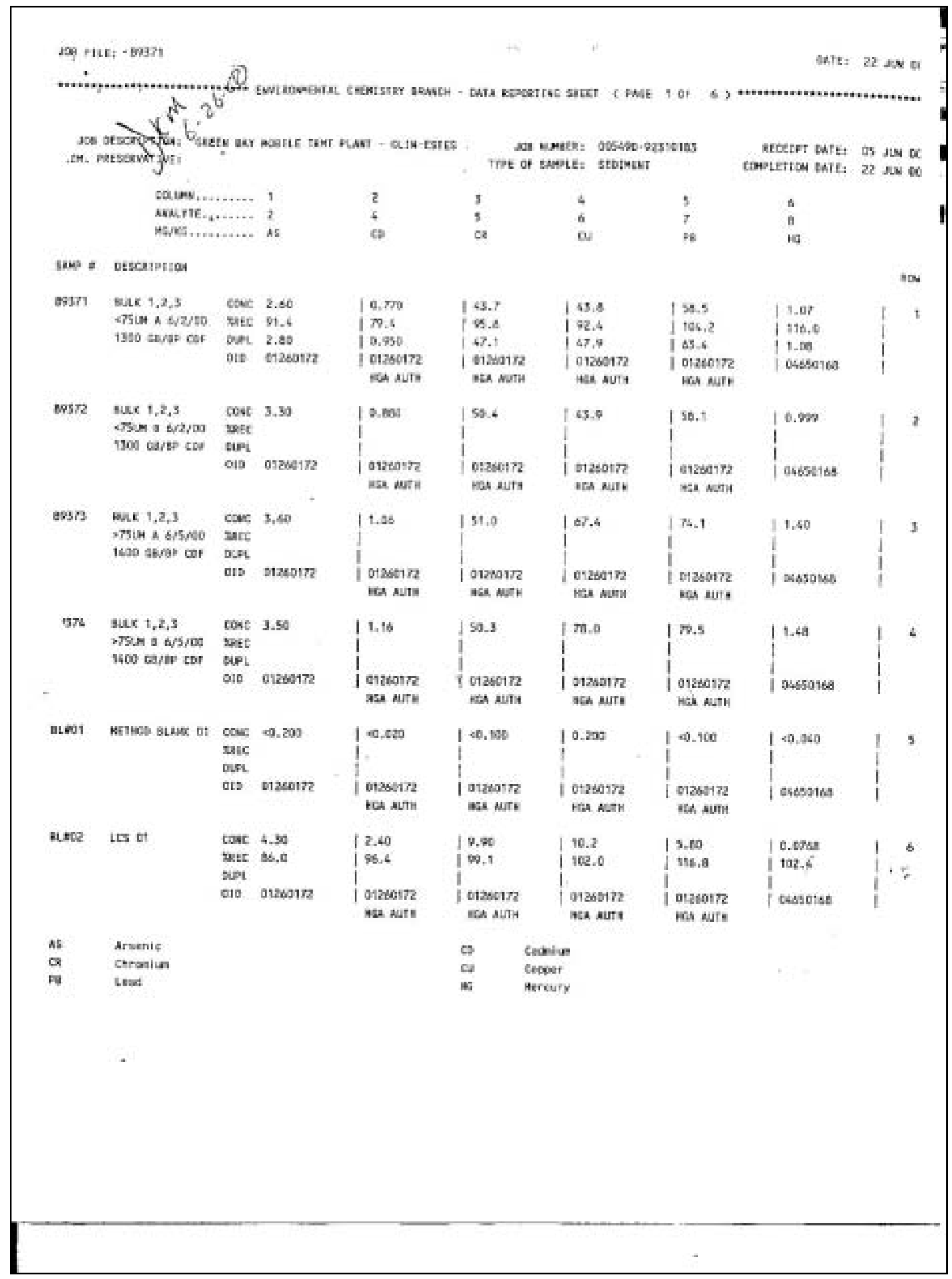




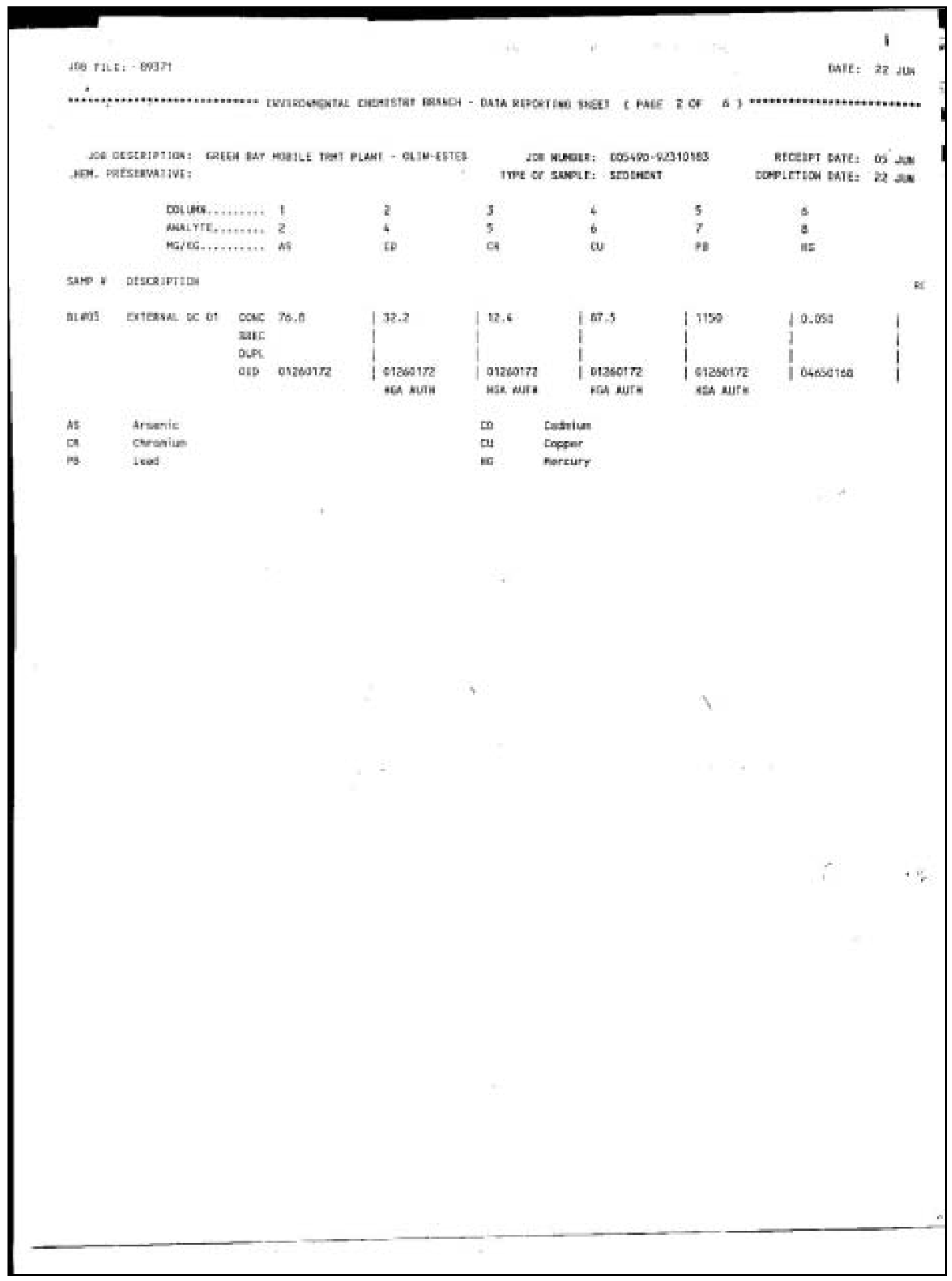




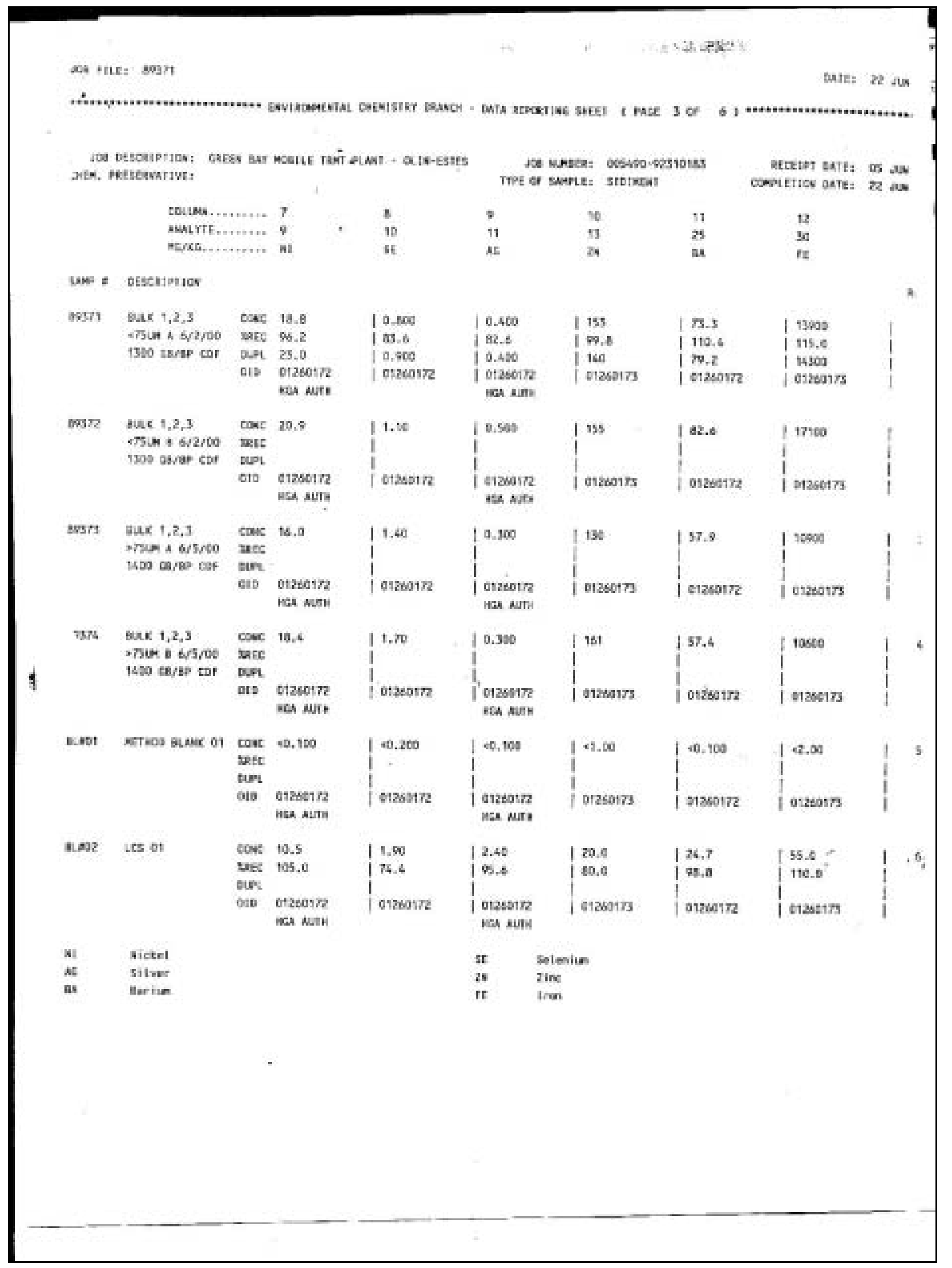




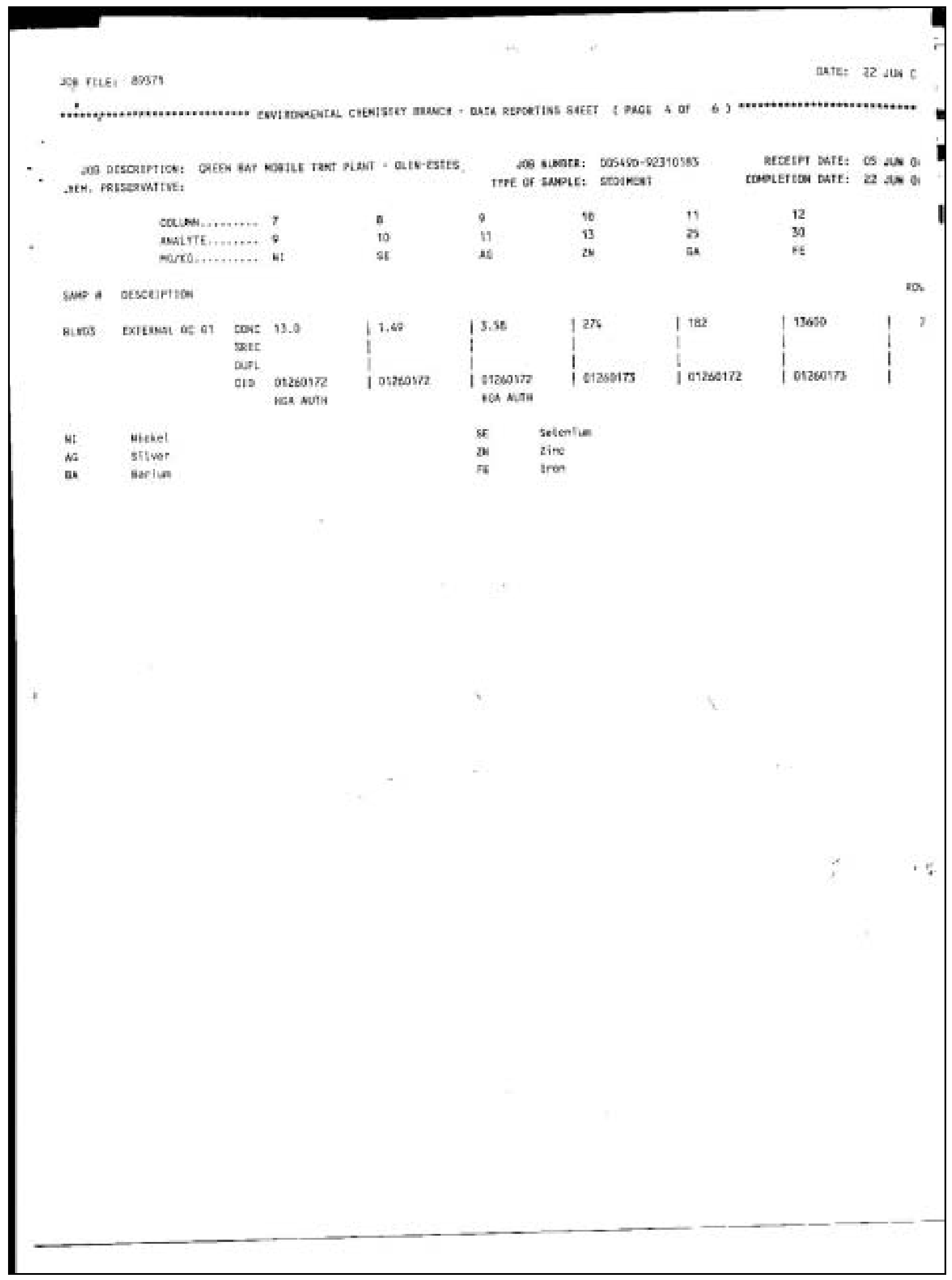




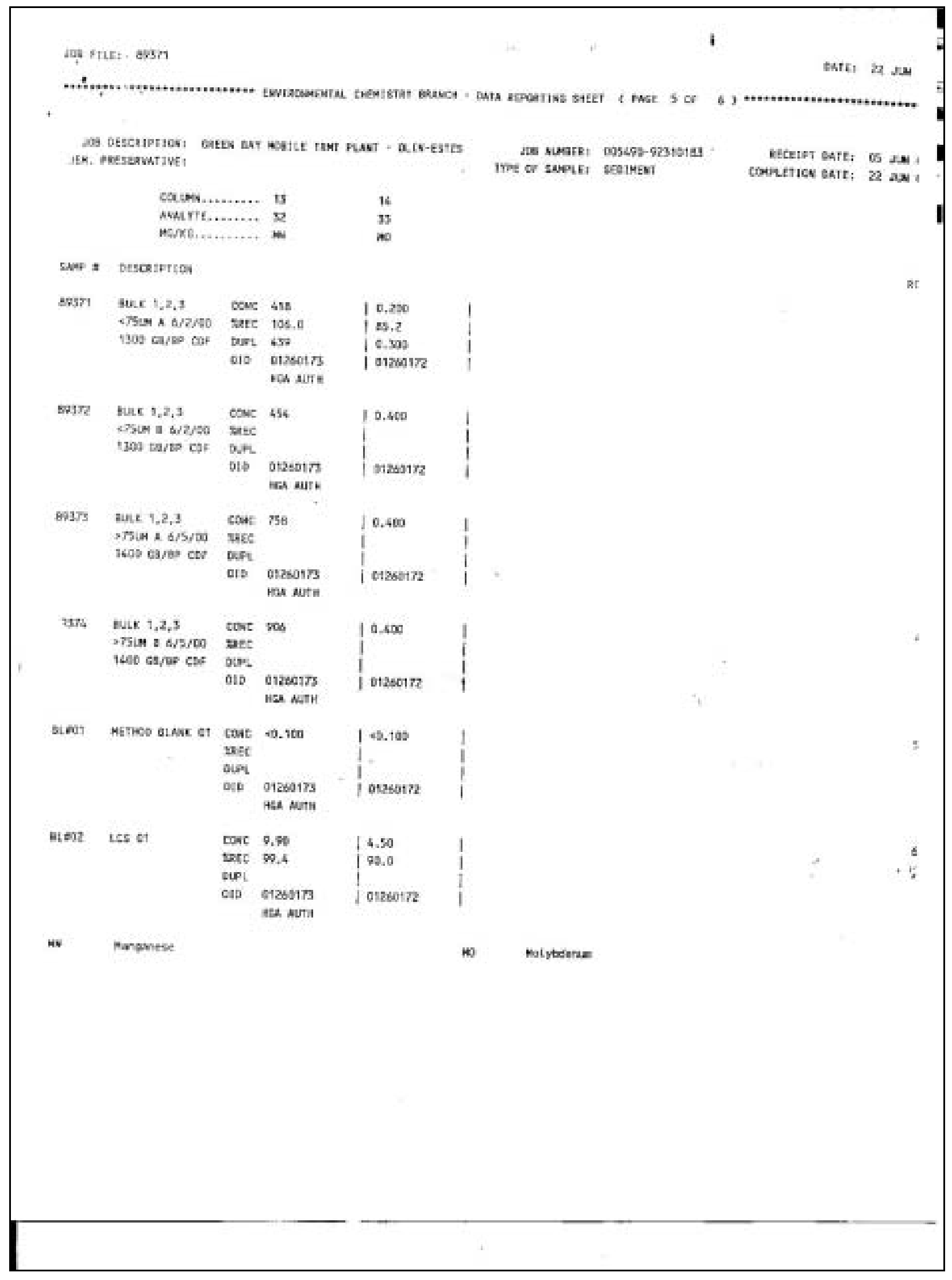




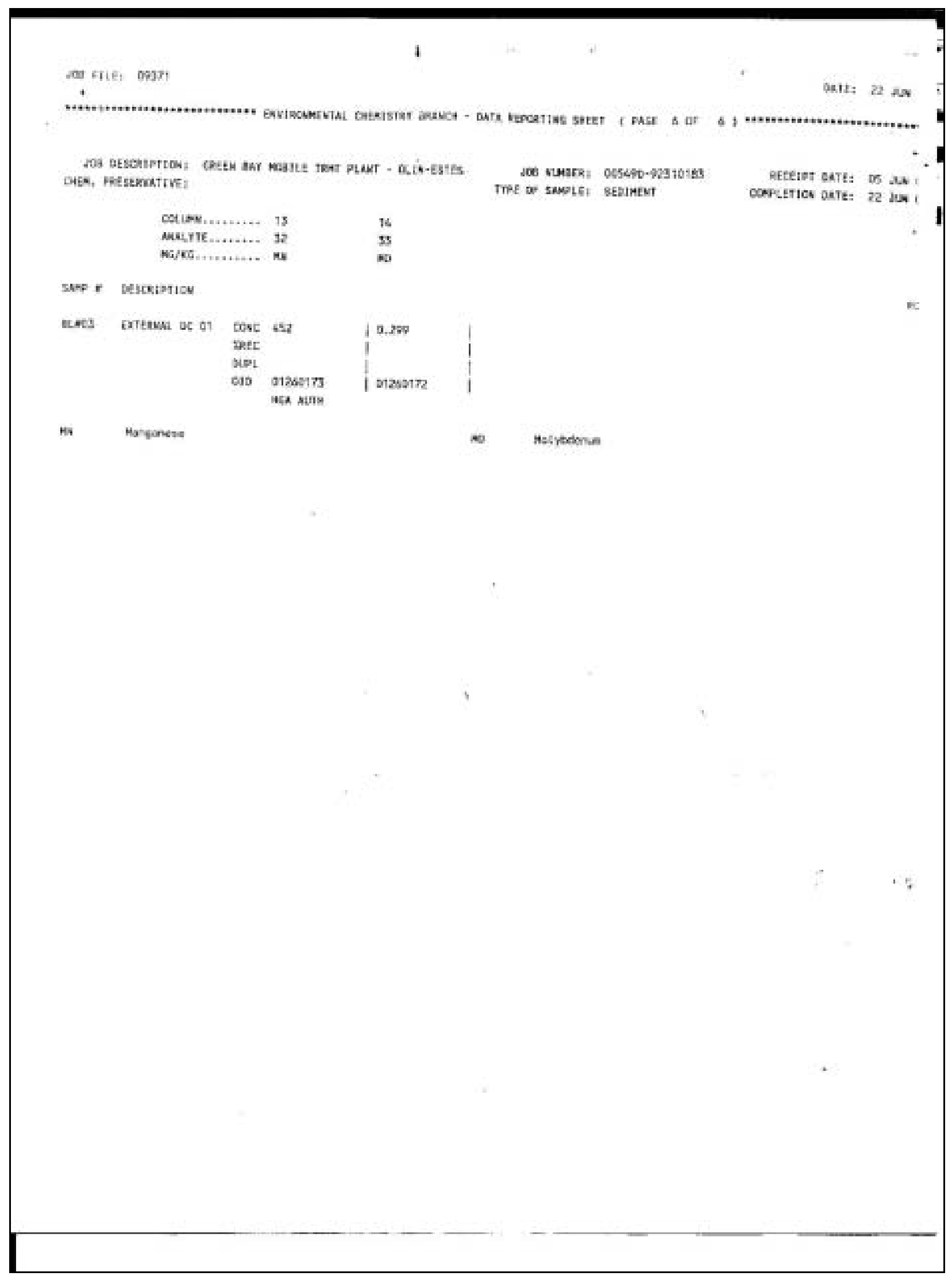




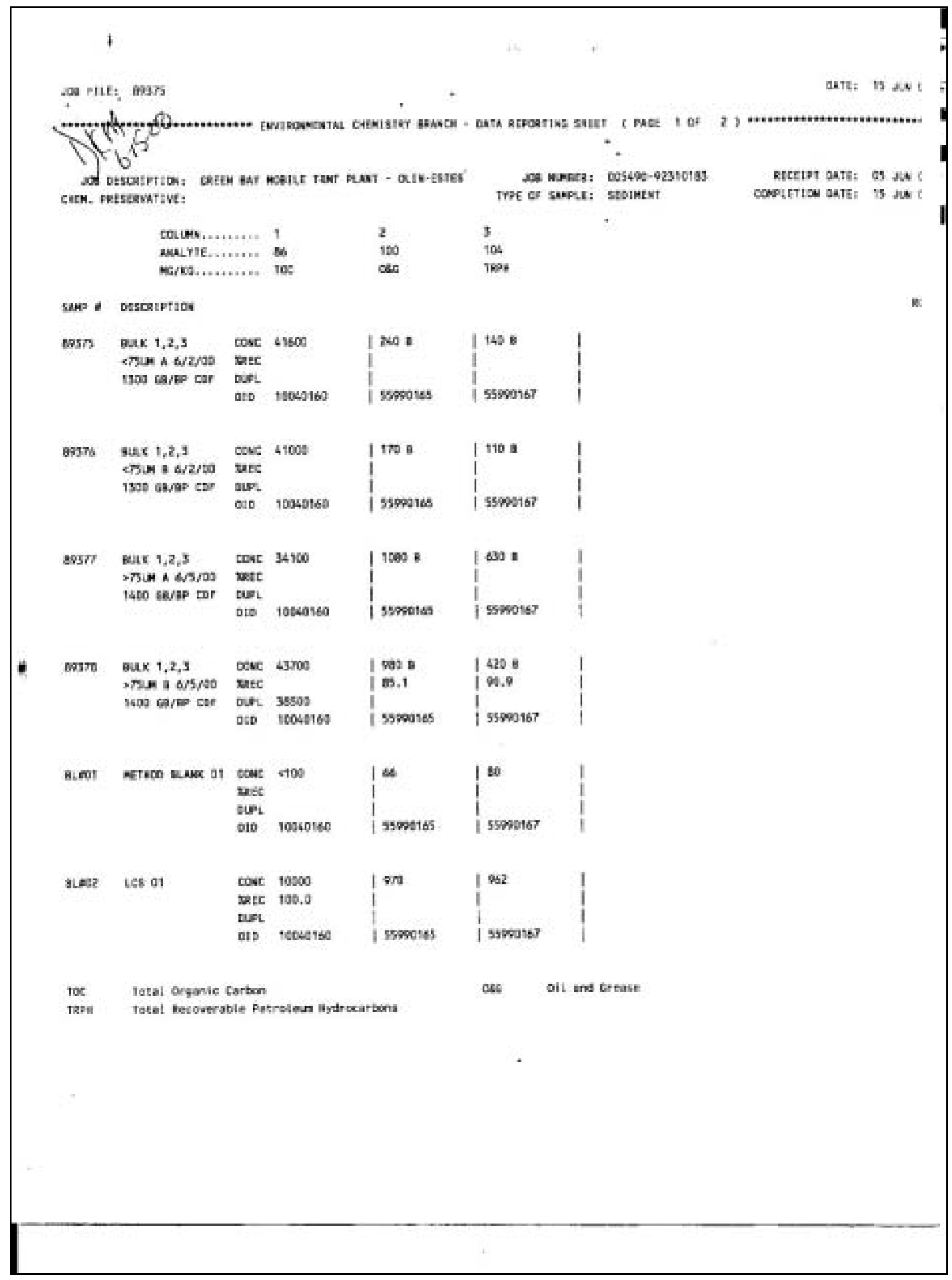




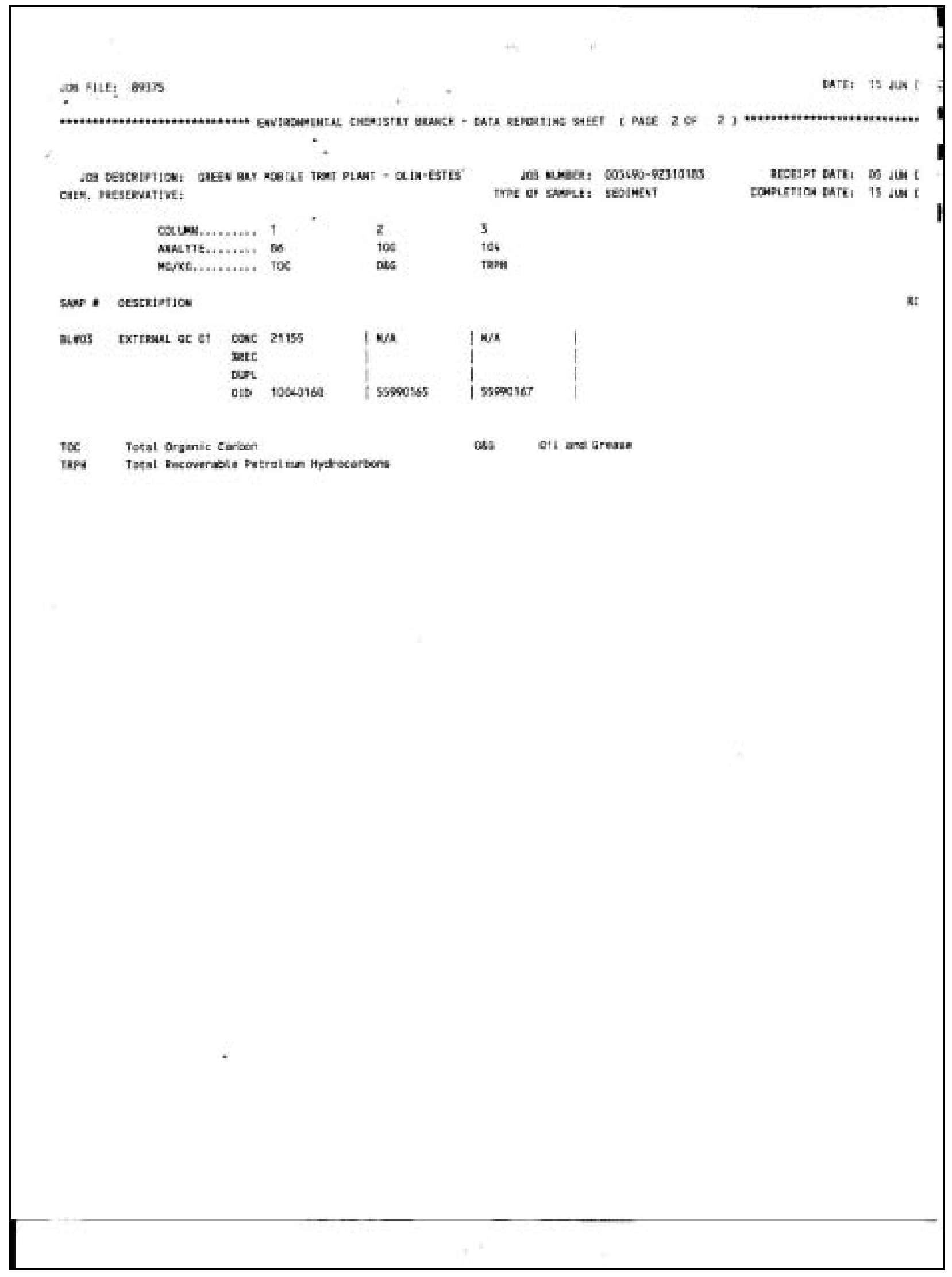




\section{INTERNAL QC DATA}

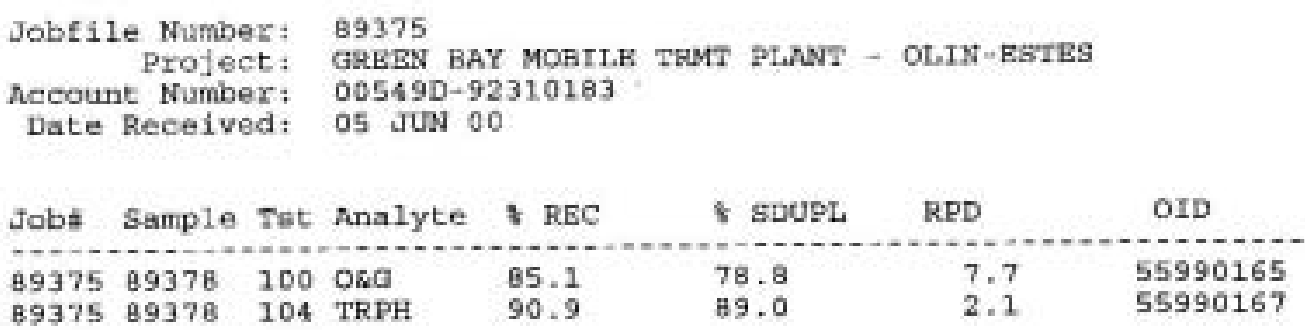




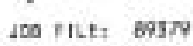

ate: $15+2$

mand X

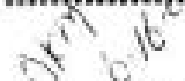

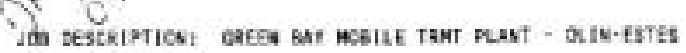
Dick, nuestruafive:

\begin{tabular}{|c|c|c|c|c|c|c|}
\hline coupw........... & 1 & 2 & 3 & 4 & s & 6 \\
\hline Asa.rIE......... & 157 & 138 & 139 & 160 & 161 & 142 \\
\hline טe/KG............ & $P C 8-1018$ & 7ct:1221 & rod-1252 & $958-1242$ & $P C D=1248$ & pet -1254 \\
\hline
\end{tabular}

Stop * Descrtonics

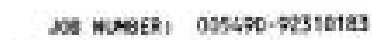
trFE of SAMLE: SEDINET

teceter caite as jok 0 conttios date: HS JW0

Acritizs

\begin{tabular}{|c|c|c|c|c|c|c|c|c|}
\hline \multirow{4}{*}{ a95\% } & Eute $1,2,3$ & tose & 25.2 & 1.28 .2 & 1025.2 & 1005 & 1.28 .2 & $<25.2$ \\
\hline & $<\sin \& \Delta / 2 / 00$ & tate & & I & I & 1 & & 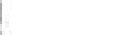 \\
\hline & $1360 \mathrm{G6} / \mathrm{s}^{2} \mathrm{cor}$ & D.r. & & I & I & 1 & & \\
\hline & & ats & 54590166 & | 54050168 & I sesones & | 54830156 & 54030146 & S5ES4164 \\
\hline \multirow[t]{4}{*}{ s9sen } & Bath $, 3,2,3$ & $\operatorname{cosec}$ & 423.7 & 1823.7 & 123.7 & \& BS & 1425.7 & 203,6 \\
\hline & $475 \cup m=6 / 2 / 200$ & tarc & & I & 1 & 1 & I & | \\
\hline & $1350 \mathrm{serap} \mathrm{cDt}$ & oun & & I & 1 & 1 & I & \\
\hline & & CID & 54832168 & I 9403056 & | 54832166 & 152490166 & 1 5esuoles & s6as314s \\
\hline \multirow[t]{4}{*}{ E9sB! } & suts $1,2,3$ & cows & -20.5 & 429.5 & 190,3 & | 1662 & $1<29,5$ & 29.5 \\
\hline & $>\pi / 4=A \quad 6 / 5 / 00$ & wec & & 1 & 1 & I & 1 & 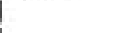 \\
\hline & S69 CA/BP CDF & tur & & I & I & 1 & 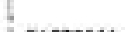 & \\
\hline & & Dio & 54800166 & 134854160 & f staseres & $1>4580160$ & 12450186 & Thaselos \\
\hline \multirow[t]{4}{*}{ ofsen } & $30 \times 1,2,3$ & cast & 429.9 & $1<29,9$ & $1+20.9$ & 11825 & 100.9 & $<2.9$ \\
\hline & STSW a A/S, & twet & & 1 & I & 1 & 1 & ! \\
\hline & $1600 \mathrm{ca} / \mathrm{CD} \mathrm{cor}$ & torl & & | & I & 1 & 1 & seasares \\
\hline & & $0: 0$ & 54990756 & 1 Scasolos & 1 94430165 & 154650166 & 154530100 & 2tabuios \\
\hline \multirow[t]{3}{*}{ Bteol } & Etron masx ot & Dowe & a. $x 3$ & I en.35 & | *ด.33 & c. & 1.5 .33 & $=8.33$ \\
\hline & & anec & & 1 & 1 & 1 & 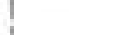 & 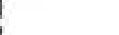 \\
\hline & & ots & 54850166 & I sassotas & S4930ts6 & I scasotes & SGESO1S4 & S4930t66 \\
\hline \multirow[t]{4}{*}{ ALAt? } & LC5 91 & $\operatorname{cosec}$ & 0.82 & I w/a & I $\mathrm{m} / \mathrm{A}$ & $\mathbf{s} / \mathrm{A}$ & I $w / h$ & $N / A$ \\
\hline & & vecc & 28.4 & I & 1 & I & I & \\
\hline & & oup & & 1 & 1 & 1 & I & 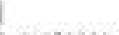 \\
\hline & & CID & 34853166 & | 54890566 & | S45801EA & $15<430166$ & I s4asotes & | 5455006 \\
\hline $103-1616$ & $F C a-1016$ & & & & $p 04-1221$ & $709=1221$ & & \\
\hline $\operatorname{rcs}-1232$ & $\cos -1232$ & & & & Fet-1252 & $F C 9-1262$ & & \\
\hline FCa +268 & $2 \mathrm{Ca}-1268$ & & & & Net-1256 & FCg-1256 & & \\
\hline
\end{tabular}


-

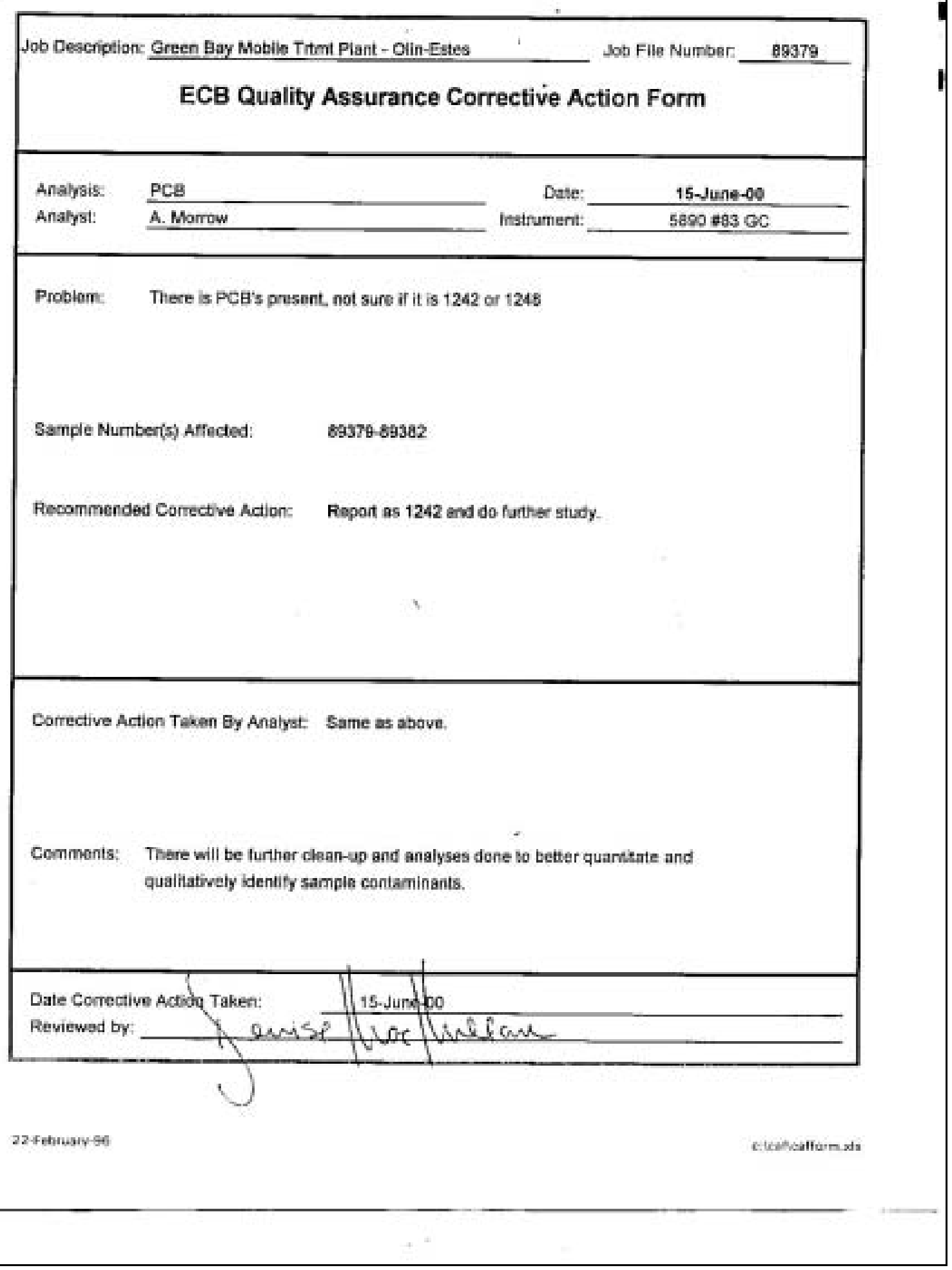




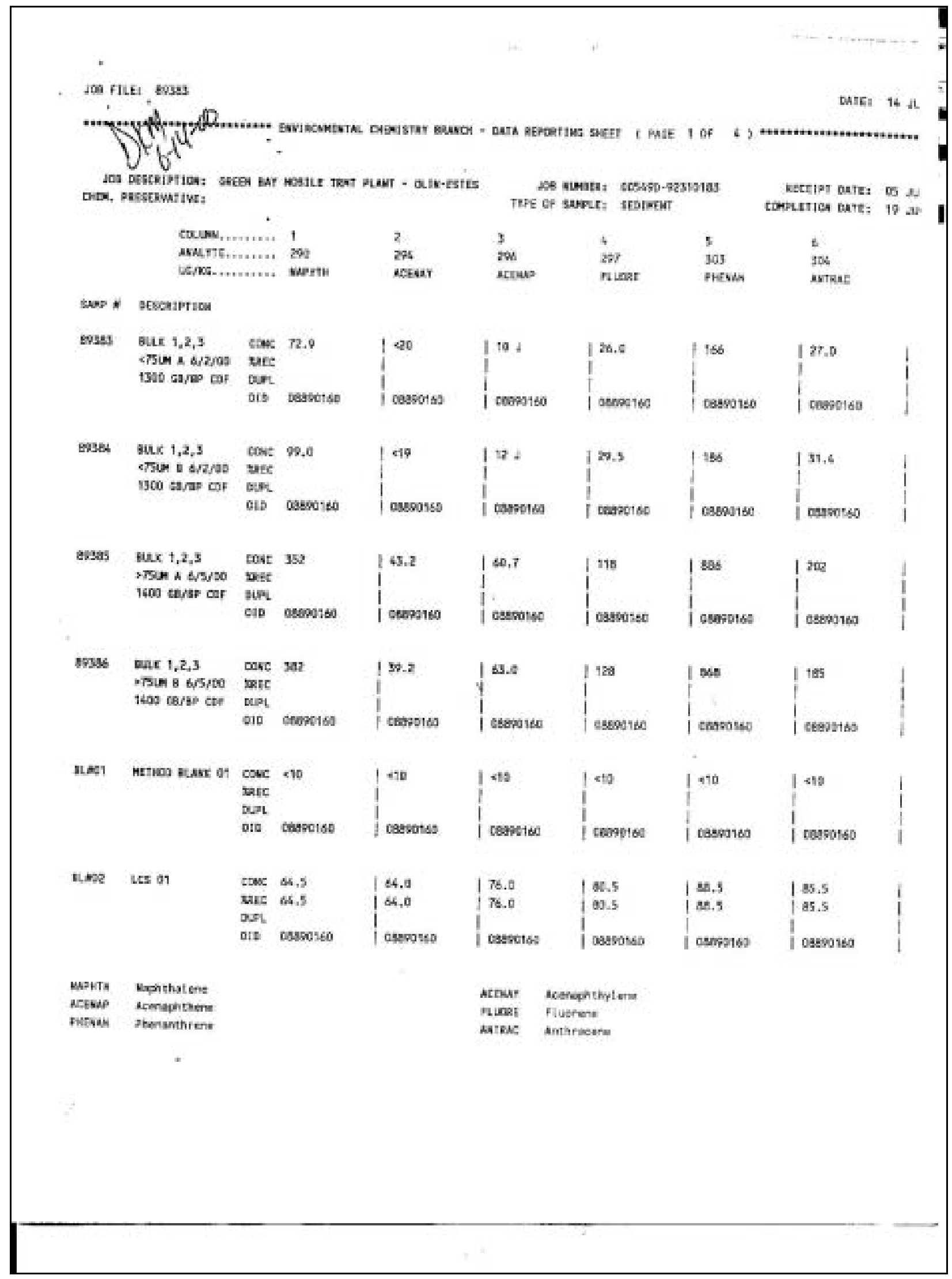




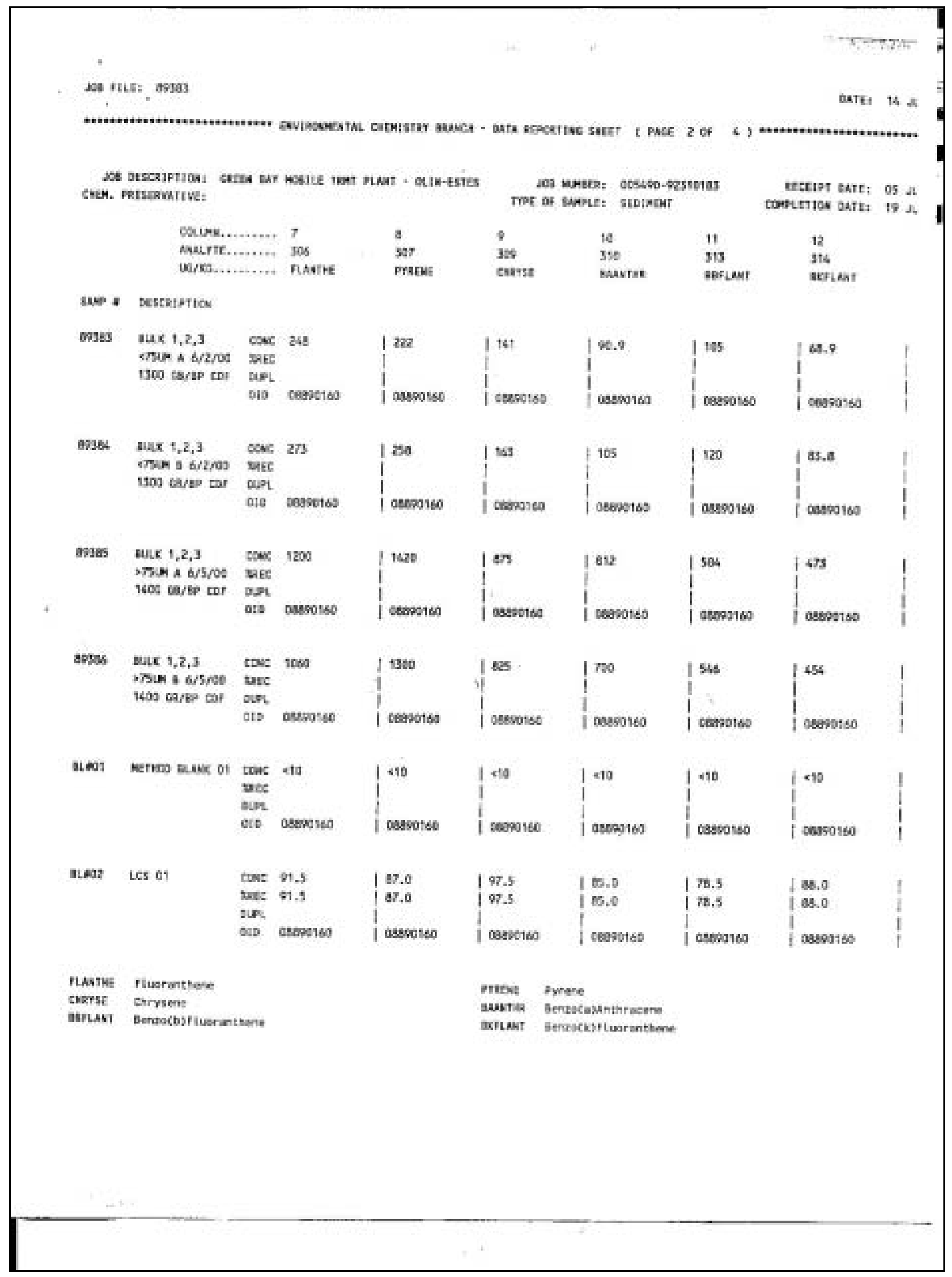




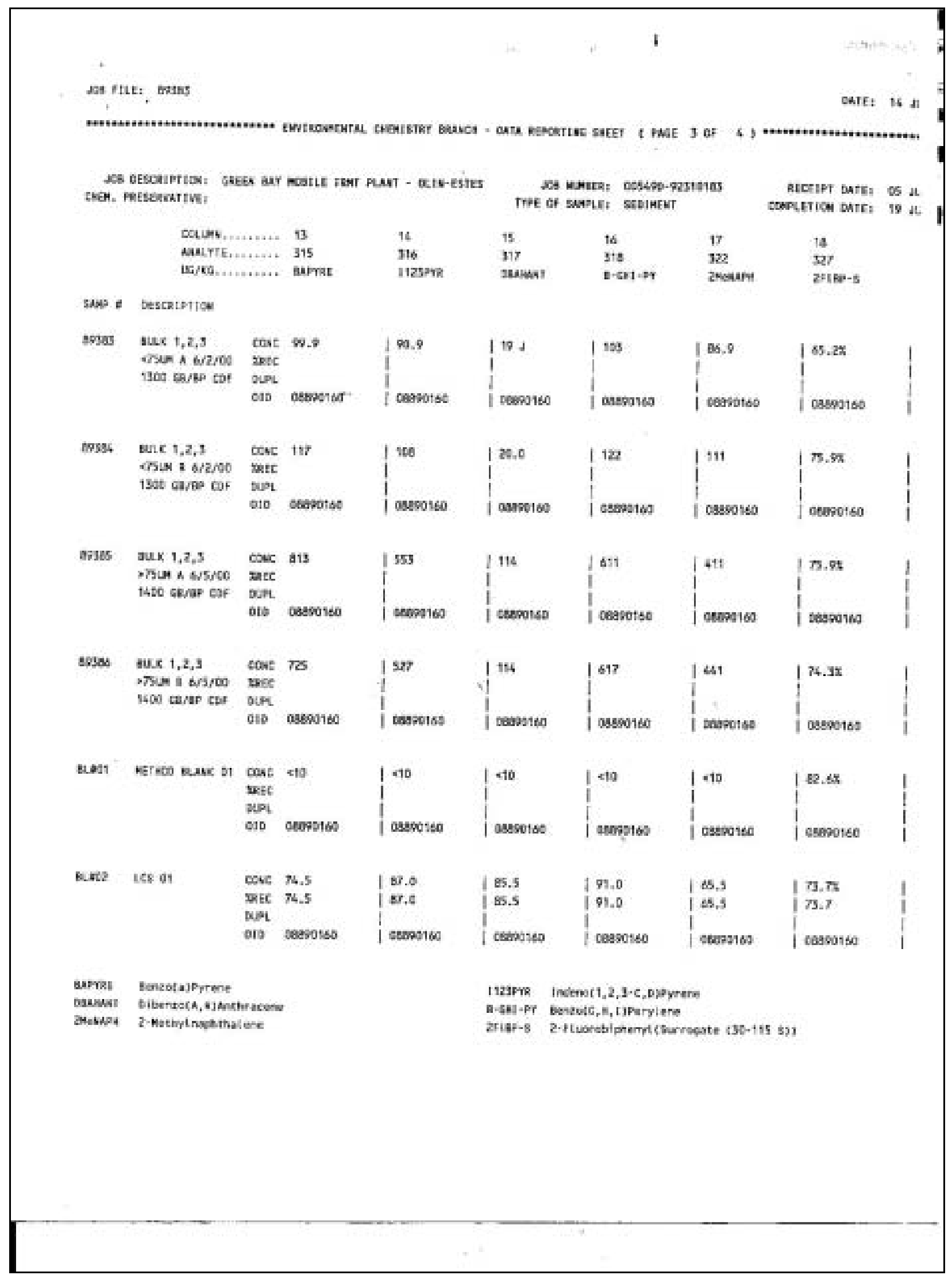




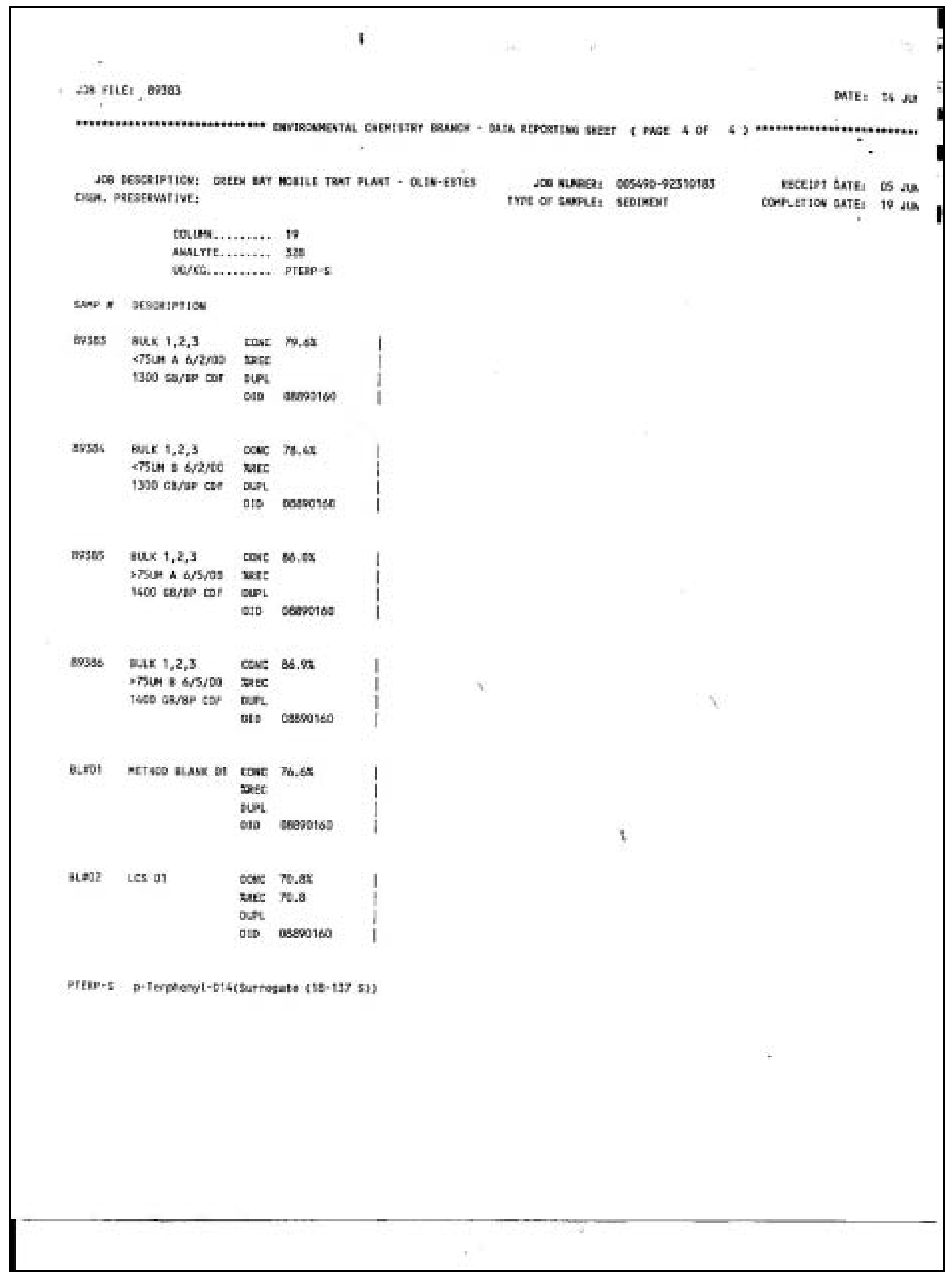


Ith the; ensts

Date: 25 LNe

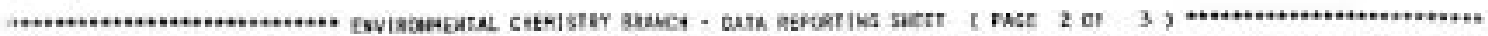

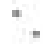

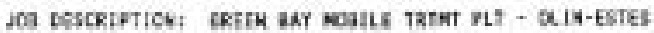

J99 unse: co56ro-92310t5s CHEA, HESTRITTET:

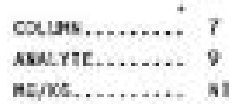

Sha * sestzintice

masas

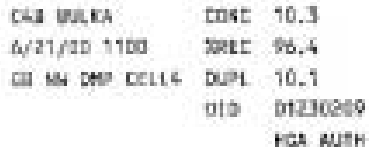

Bteaz tes ot

$\cos 21,5$

tate 109.0

Dan

eIB 01230259

1020 NITH

atass eareasul of ot

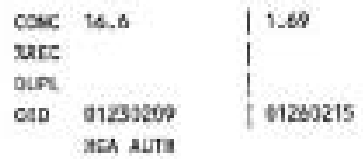

N1 Micknt

a) คิง

$\begin{array}{ll}3 & q \\ 10 & 11 \\ S E & \text { NI }\end{array}$

\begin{tabular}{|c|c|}
\hline 8.499 & 0.250 \\
\hline 105.6 & 17.6 \\
\hline 10.660 & a.tw \\
\hline I 012sress & ब122002 15 \\
\hline
\end{tabular}

$\left\{\begin{array}{l}74.5 \\ 50.5 \\ 74.5 \\ 0 t 23005\end{array}\right.$

ACA Nath

\begin{tabular}{|c|c|}
\hline 0.560 & 10.700 \\
\hline & 1 \\
\hline & 1 \\
\hline ดา2ะaวาร & 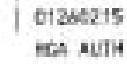 \\
\hline
\end{tabular}

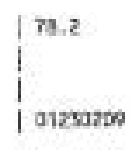

I

i

40.750

| $=5.260$

94260215

1 aseceats

I $e 1,00$

I

I

wate unte

\begin{tabular}{|c|c|}
\hline 6,96 & 14.50 \\
\hline 02.5 & i ตs.8. \\
\hline aงวยมว & $\begin{array}{l}\text { đ1260275 } \\
\text { tea A411 }\end{array}$ \\
\hline
\end{tabular}

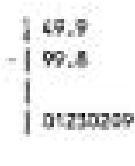

I

14.69

1

Diascets

| 282

i

ans nit4

1 ง1290200

I

$\begin{array}{ll}\text { SE } & \text { Soleniun } \\ 2 \mathrm{H} & \text { Zine } \\ \text { FE } & \text { Iren }\end{array}$

RECEIDT ta? 5 : 26 dus STOLIETION BRTES 3 NuS I
12
30

IF

$\begin{array}{llll}10 & 11 & 12 \\ 13 & 25 & 30 \\ 21 & 84 & 75\end{array}$

140.5

I 95,6

40.5

01253200

1796

169.0

1750

or2spess

$\mathrm{N}, \mathrm{T}$

ersacas

1

10.100

6tz30300

a.to

151.0

| 102,0

0123azon

סוים,

a123a2m

1 185

21239000

1 24905

01290209 


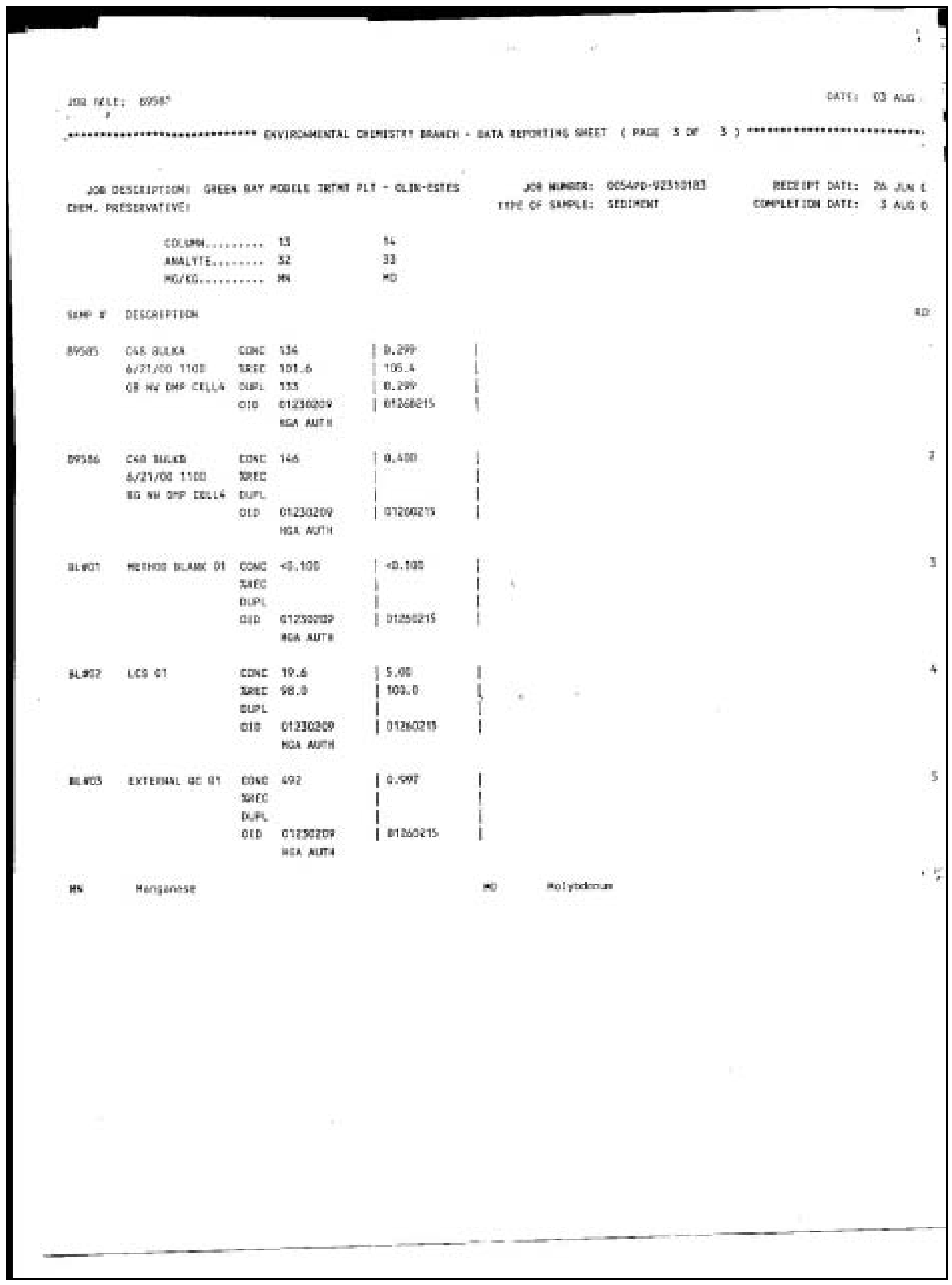


we rik:1 69,87 - 4

axt, $13 x$

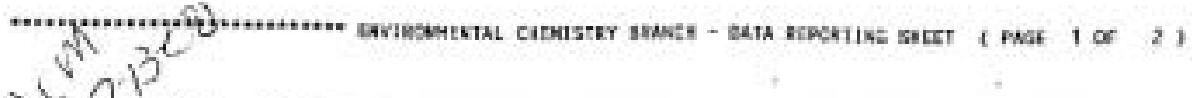

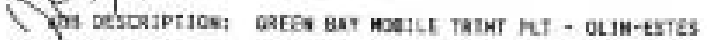
che\% nestavarave:

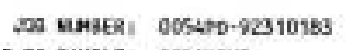

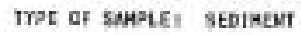

$3 \quad 6$

CD, $194, \ldots \ldots \ldots$.......

ANALYEE....... 13\%

Garkc............ raterth

2

118

9C8-122!

rea-t23:

260

PCE 1292 yt8-126s

grcelet batr; 25 Ju । oCNOLEHOA BArEt $13 \mathrm{Je}$;

6

142

PCE- 1254

Sarp $\neq$ Descasprice

$$
\begin{aligned}
& \text { Cac: } 412.7 \\
& \text { sorstreo } 1100 \text { 5ase } \\
& \text { IC MU DHP CR.G DND }
\end{aligned}
$$

| +12.7

i

sempess

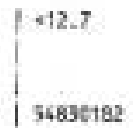

$\left\{\begin{array}{l}\mid+2.3 \\ \text { seasotas }\end{array}\right.$

$\mid \begin{aligned} & 5757 \\ & 54 a y 0 t a 2\end{aligned}$

i 12.7

spos

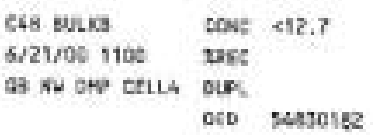

C68 BuLca

as Nu CN CtLL DLP.

QtD \%user

$\left\{\begin{array}{l}0.7 \\ 54853152\end{array}\right.$

| 512,7

I

I

1 S4590142

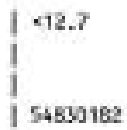

3722
1
isnsolas

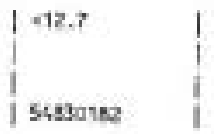

Dieci Mithes alask of cosc ah, 3

xarc

010 stessian

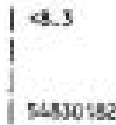

I 4ด, 3

I

is $543918:$

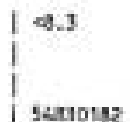

$\left\{\begin{array}{l}0,3 \\ \text { seasones: }\end{array}\right.$

I va.3

I

Nuter Les os

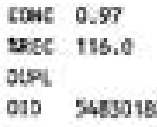

I vara
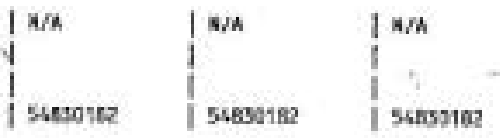

$\left\{\begin{array}{l}w / h \\ 54890582\end{array}\right.$

1

PtE-15is PCB-1016

NEE-12s2 pen-1232

Net-1248 pts-1258

PCD:1221 AC9-1221

ICD-1242 PCF-126?

PCD-1254 POI-1256 
106 filt: atsay + +

Bart: is un

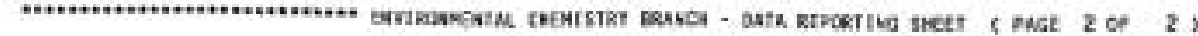

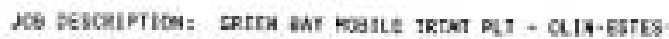
CREM, PAESERELIIVE:

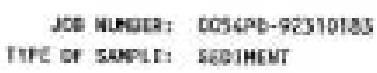

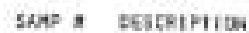

assar
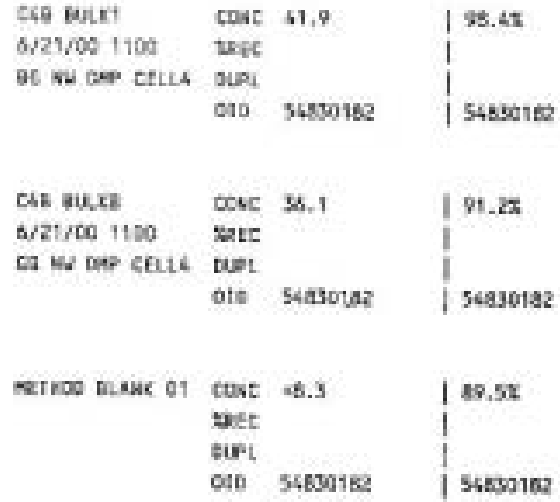

190.25

I.

56850182

ELeaz LCS DI

$\begin{array}{ll}\text { cow: } & 5,03 \\ \text { zarc } & 125,0 \\ \text { ben } & \end{array}$

| $96 . \pi$

1

i

| 54asoses

$\mid$\begin{tabular}{|} 
as.ex \\
$\mid$ sussonaz
\end{tabular}

FCD-1260 PCE-1263

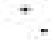

MrCtIPI DATE: 26 dU tomplction baft: is ju:

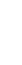


$\frac{15}{7 / 2 / 60}$ tites - assas

baft: $11 \mathrm{HL}$

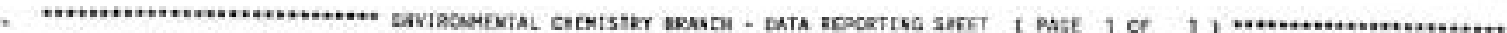

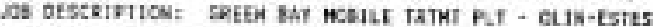
Ciem. Meservative:

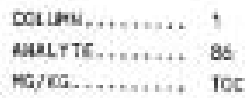

NGIeg.....

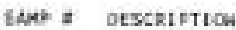

avs:s

$$
\begin{aligned}
& \text { c4e vuLe } x \text { cove } 26+50 \\
& \text { cas etostay }
\end{aligned}
$$

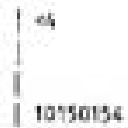

1250

1

6ospo
Sts aisc a

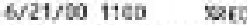
68 w ten chit buFl.
Dic 69540567

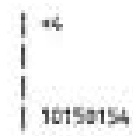

| 210

1 4,9

I

| s599040

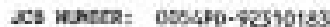
Troe of suest: sFolRent

REcein teats 26 ju COPLIETICN BATK? 11 aU

4

100

cse

tet

TRE

ris

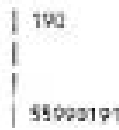

1

I 180

169.2

I

I ssonest

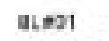

\begin{tabular}{|c|c|c|c|c|}
\hline \multirow[t]{4}{*}{ BLroz } & \multirow[t]{4}{*}{ Les et } & cove & 6640 & $1 \mathrm{k} / \mathrm{A}$ \\
\hline & & zarc & 94.6 & I \\
\hline & & DSPL. & & I \\
\hline & & ars & caccays? & | rotsotss \\
\hline \multirow[t]{4}{*}{ UL: } & \multirow[t]{4}{*}{ EatFanel se of } & $\operatorname{trat}$ & zotto & $1 \mathrm{~s} / \mathrm{h}$ \\
\hline & & wht & & \\
\hline & & sui & & 1 \\
\hline & & 010 & toosbtar & 10150156 \\
\hline
\end{tabular}

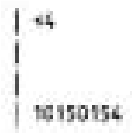

I as
i sonstar

Toc Total Organic tarbon

obl ant and srease

I 92

19.7

I

155090128

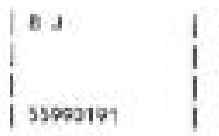

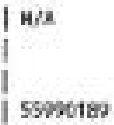

\begin{tabular}{l|}
$\mid N / A$ \\
$\mid$ |
\end{tabular}

Tatal Vatatile folids

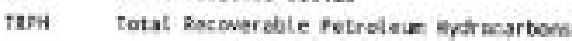




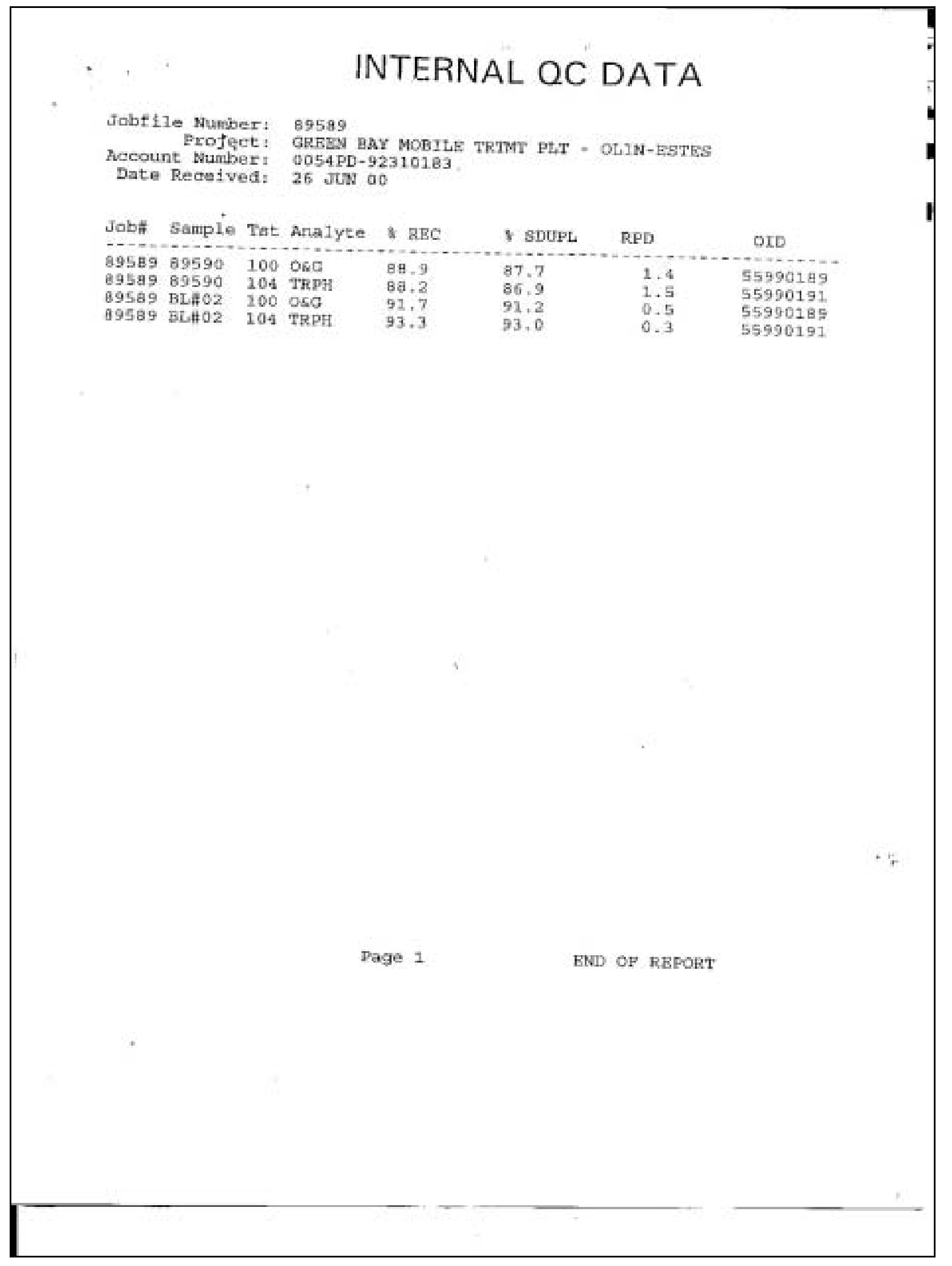




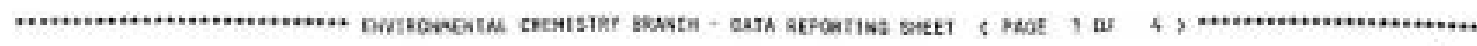

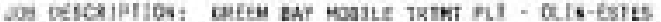
Datm. MEservafive:

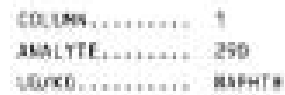

3

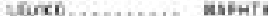

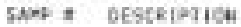

ตำ1

CSe Butc *

$6 / 21 / 031100$

QR su aw CELLS our.

อID 0uspist

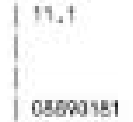

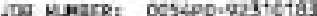
Tror do suases stother

nectipt DMTE! 26 HQM

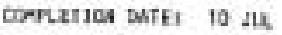

\section{3}

atene

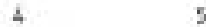

297

flume
6

axras avs

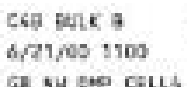

Ge w ter cills oif

$\begin{array}{ll}\text { sowe } & 126 \\ \text { ure } & 23,0\end{array}$

cipt

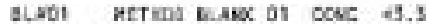

taec

p.ry

ctD ossocset

atre tes of

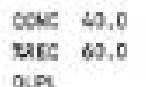

OAP

cIs asmons

$\left\{\begin{array}{l}17.3 \\ 59.5 \\ \text { cospose }\end{array}\right.$

148.5

162,5

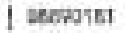

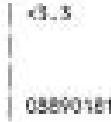

$\mid \begin{aligned} & 4,3 \\ & \text { secositst }\end{aligned}$

$\left.\right|_{\text {aserovet }} ^{9,3}$

1.5

i

cassoust

| 258

I 49.3

137.5

77,

cosตa1s:

eq.3

1

atengts

deavis

\begin{tabular}{|c|c|}
\hline 43.7 & 149,0 \\
\hline 65.5 & 17.5 \\
\hline 81 & \\
\hline
\end{tabular}

$\left\{\begin{array}{l}52.0 \\ 73.0 \\ \text { cespops: }\end{array}\right.$

155.7

| 20.5

I

| tasacis
54.7
82.9

| asconsi sagrit Sashtiatem

actwe Mcenaphthene

Antase Phenarthrens
AEtrar Acertaphthylone

nuese rivaretw

Astewe Amthrecere 


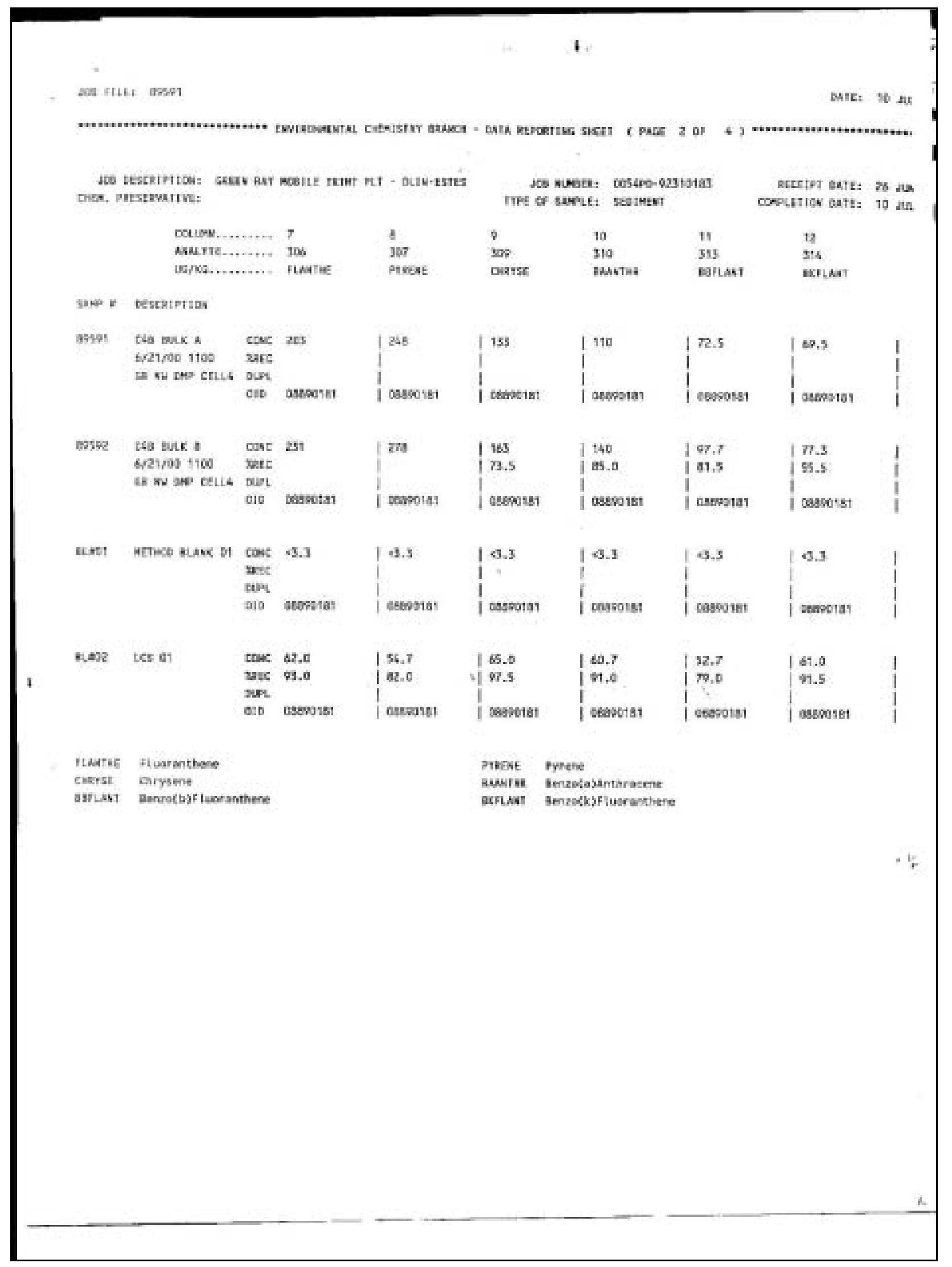




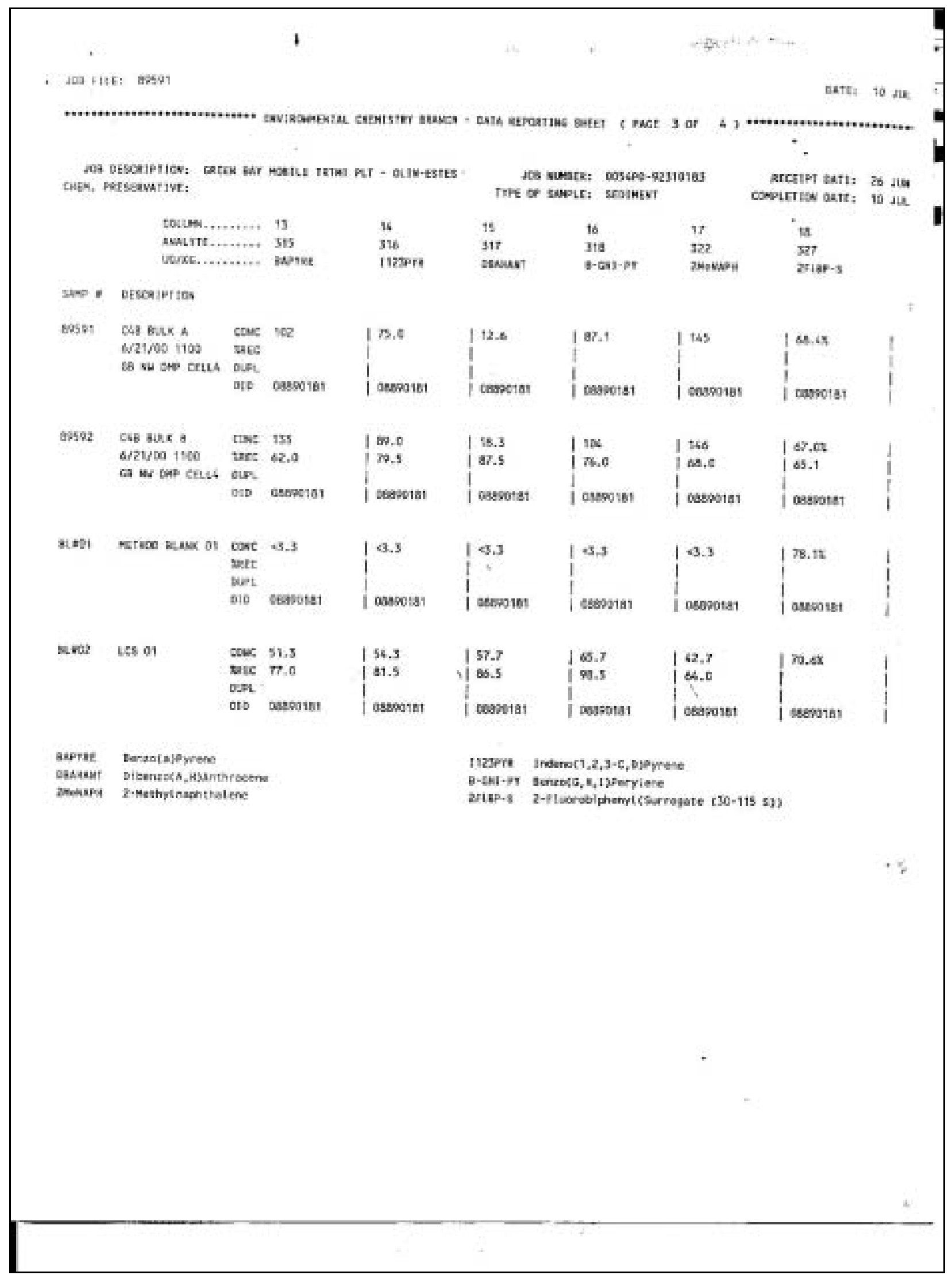




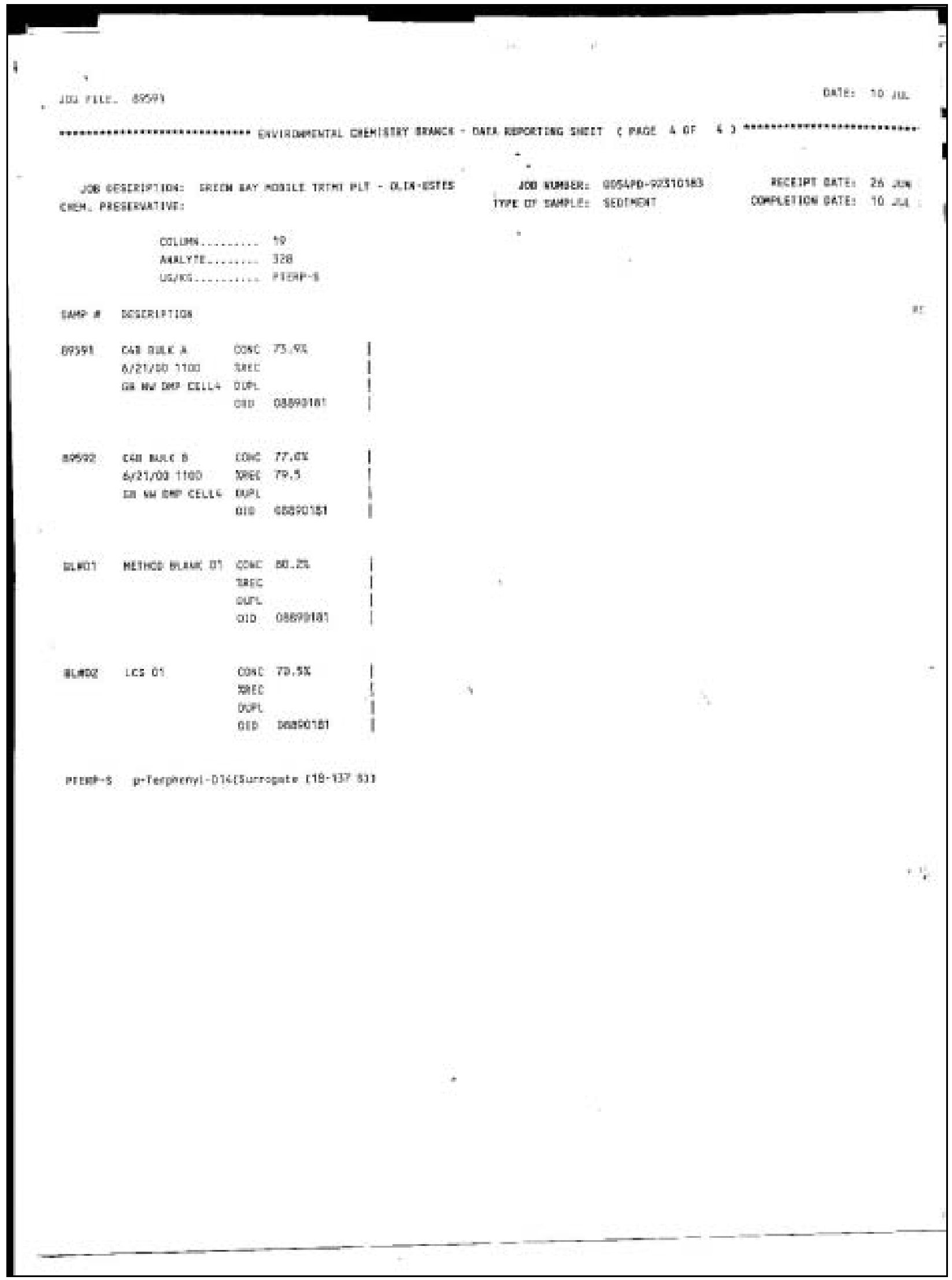




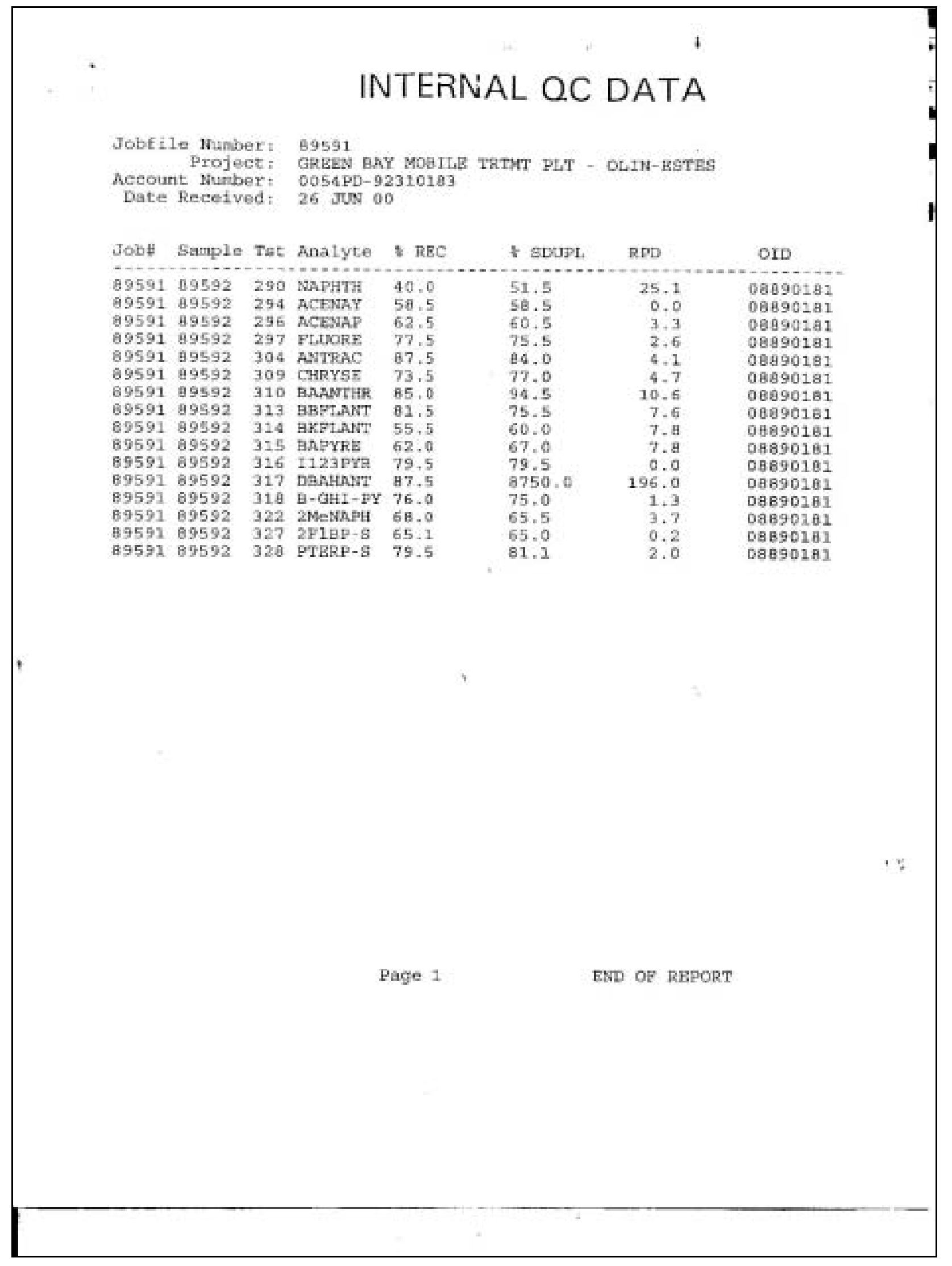


$\left(\{, 3)^{2}\right\}^{2}$

4hos: ite: asmas

ASte: as Ais

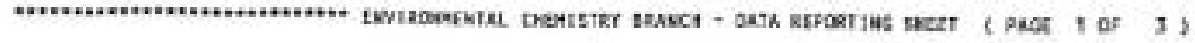

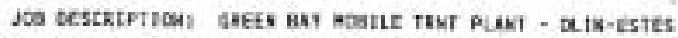
cten, vastrattike!

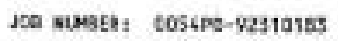

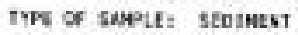

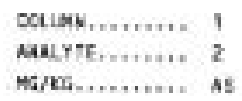

Lat a bescriptica

89723

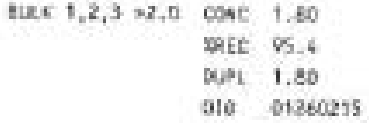

1 91,6

10,690

I ameaces

vas wars

nares

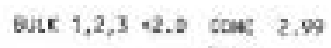

I.,

i

1

012ลav1s bes autK

$1+6.022$

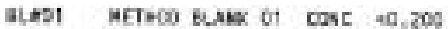

$$
\text { tratr }
$$

Deit

010 012002า

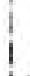

| 07260215

Ha dath

Bune tes o1

$$
\cos 9.40
$$

uEC 93.?

DUF

OCD 0:206215

| 6,49

198.9

1

61260215 Ira AUTH

aloos rriebul ac at conc Ba.t

west

DUil

oro erasog:s
37.1

I

01260ess

mas auts

3
5
12

6
6
cu

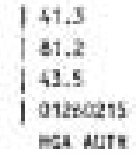

AS.2

| 01264215 *a s a

140,100

I

1

องเมn2าร

usa arr

18.5
95.6.

$i$

| $0125 \mathrm{~m} 215$

rCA जUTH

122,5

1

I

I g12eozis aca NIT
127.3

176.5

20,6

Dizscers

ea surn

187.2

i

| otzeozts

nes aurA

10.660

I

I

01250215

va suir

17.6

$-187.0$

I

| a126azts

was A.TA

1 86.9

i

I 01250215

wa sutr aecernt eates oे dLI । contetion asie: I AW

b

ir w.z

141.8

( ) D1230230

sca mire

| 51.0

I

1

I 01250200

Mas Aงsh

$1 \times 1.00$

I

I

| 01230009

ach sur:

| 21.0

$1 \% 5.0$

I 3

has $051 \mathrm{~s}$

11160

I

o12s0009

asA AUTA
1 0.625

I 905.2

0.531

$046507 \%$

12.20

i

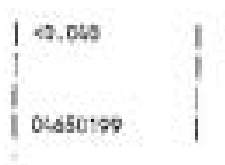

| 0.0752

100.3

I

1060019.

$\left\{\begin{array}{l}0.053 \\ 10050100\end{array}\right.$ $\begin{array}{ll}\text { As } & \text { Artenie } \\ \text { CR } & \text { Crrositus } \\ \text { FB } & \text { Lesd }\end{array}$

CD Easulue

cu. Capoer

la Nercury 


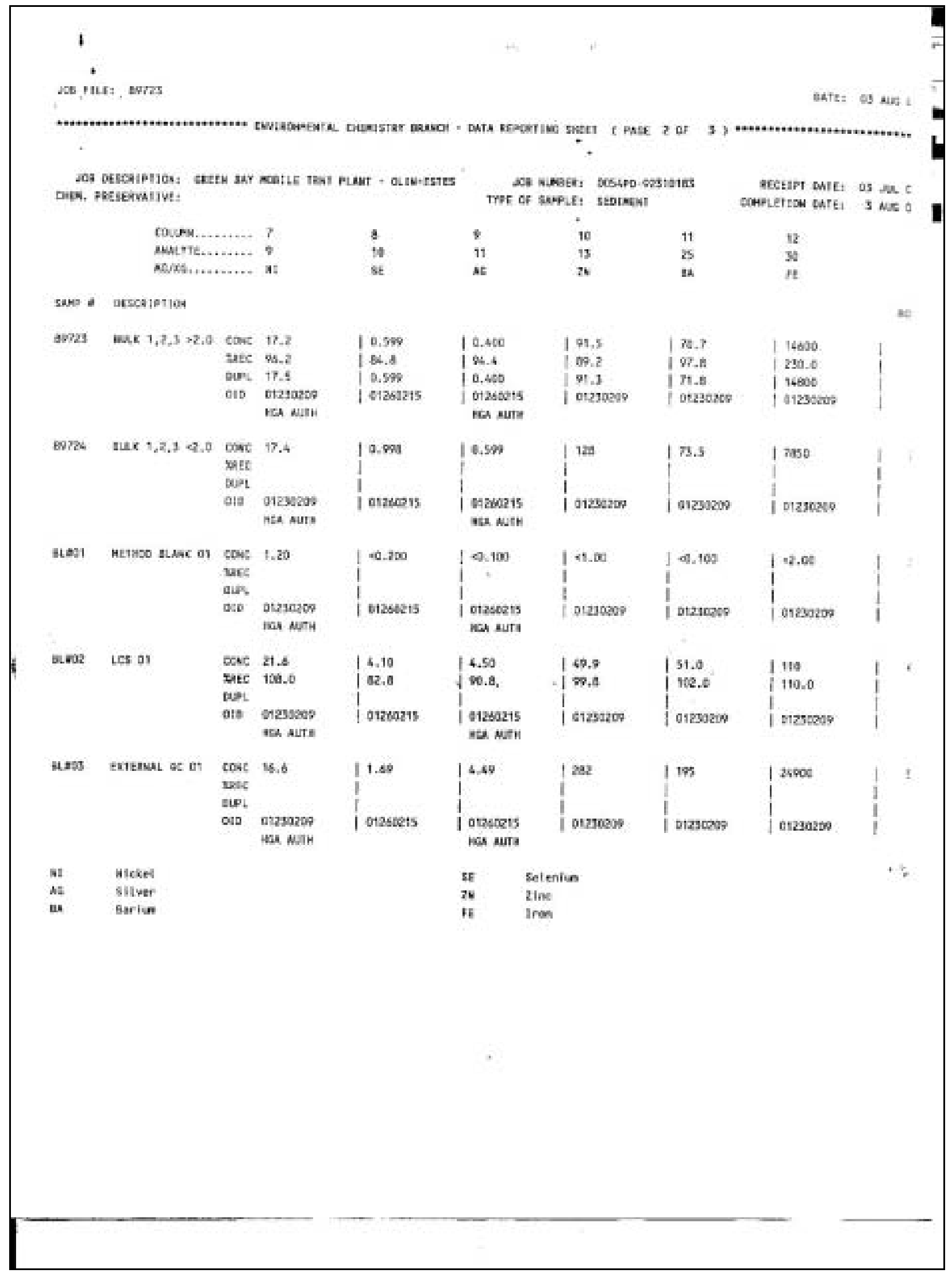




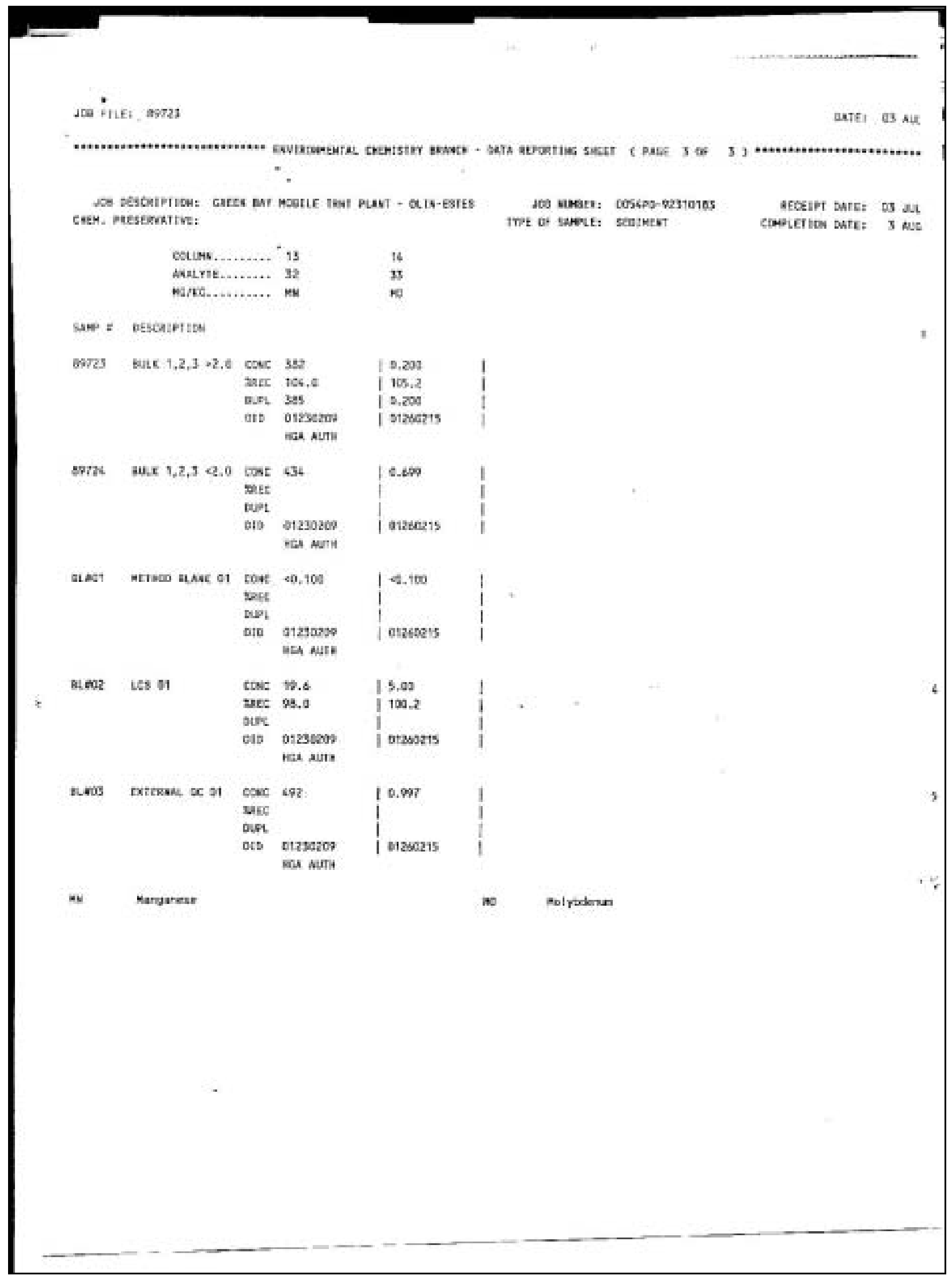


fK

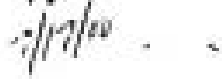

joe inte s9m2s

Bfte: $17 \mathrm{du}$

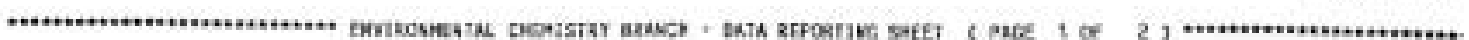

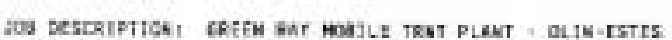
CHEM, IIESERrativf:

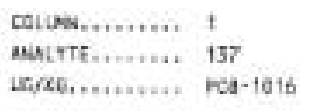

$5200 *$ Descrintios

1. as?25 w.e $1,2,5 \times 2,0$ tove ats.8

2ute 74.4

curl

oto s4835193

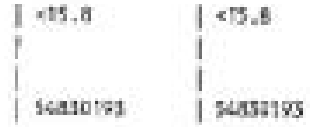

J08 numeer 035486-92310165 TYPE OF BAFLI SEDIMENT

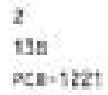

3

139

aca-1232

4

no

PCB-1262

164

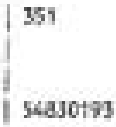

คCB-1245

kEceIgT Gare: 03 sUl

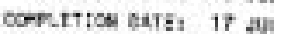

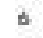

462

PCE-1254

6N7.

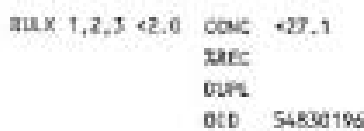

$1=2 t, 1$

I

Stabpine

gtal1 keriog buk or cosc of 3

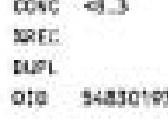

DLec Les o!

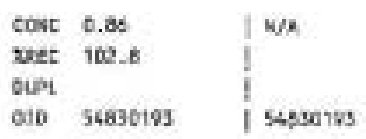

pC4-1916 va-105s fc9-125? pc8-1232 FCa-126! $9 \mathrm{CB}-1244$

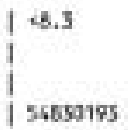

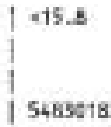

$1+15, \pi$

ง.songs
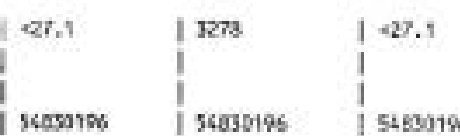

$\left|\begin{array}{ll}-2 r+1 & \mid \\ 5425025\end{array}\right|$
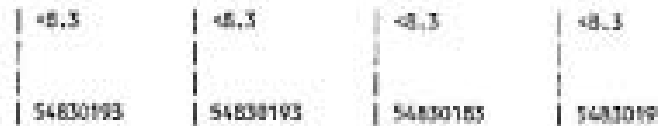

I $1 / 2$
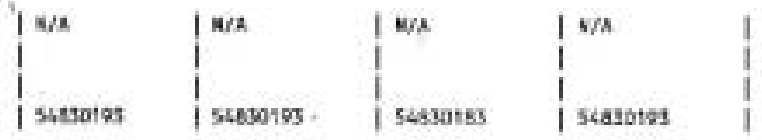

ros-122t PCa-122t

PCa -1262 PCA 1262

poa-1254 pa-1254 


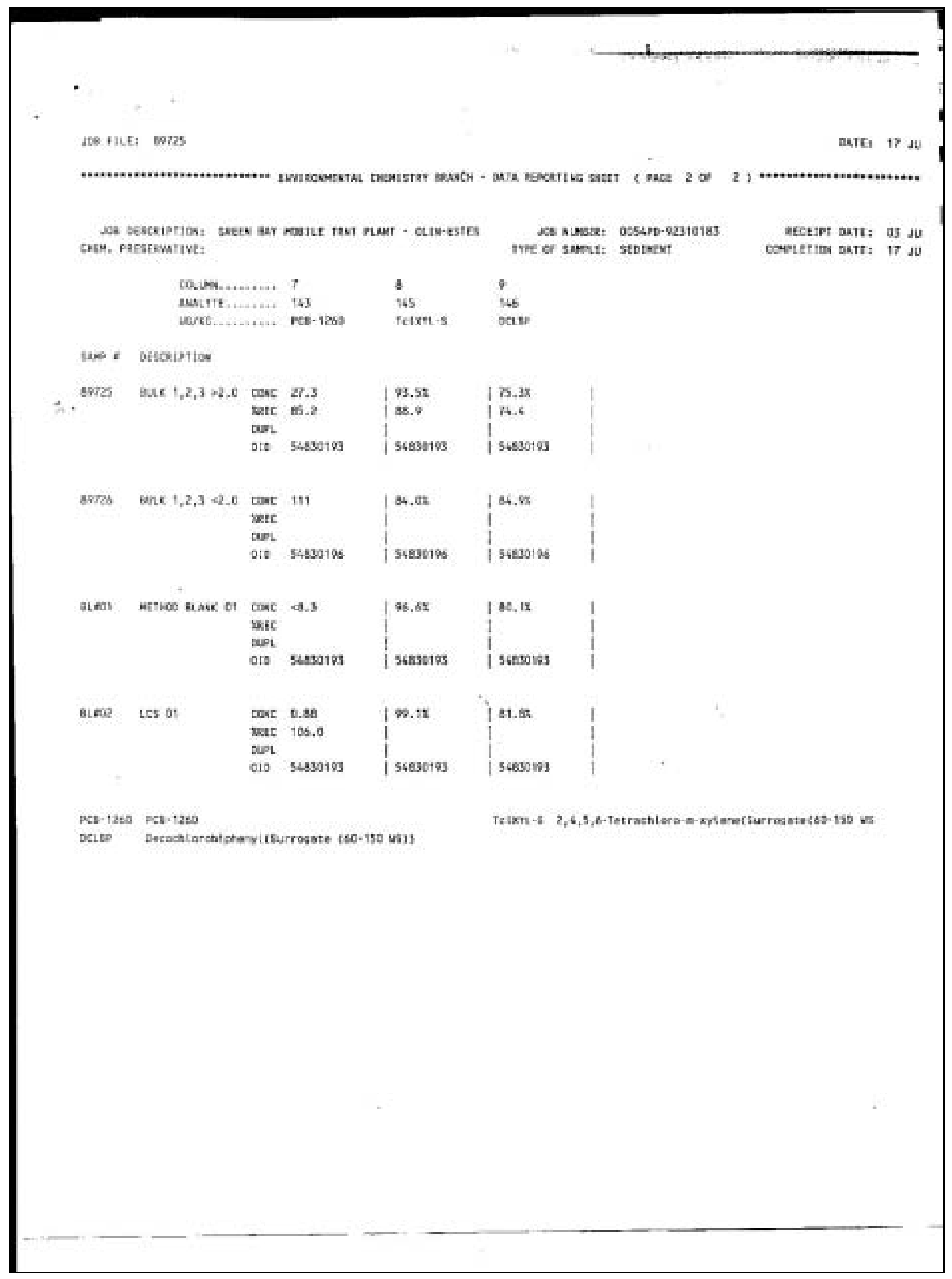




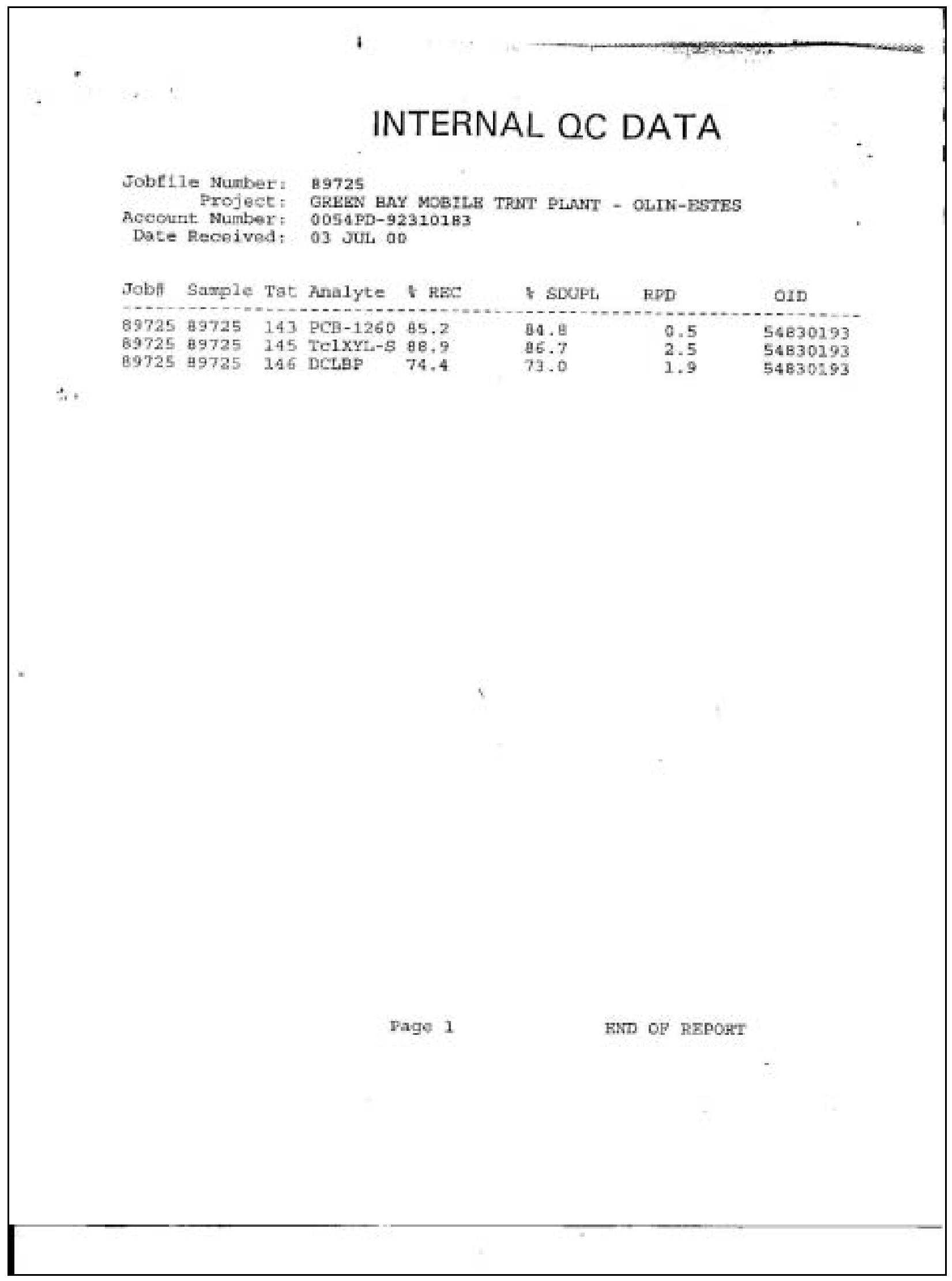




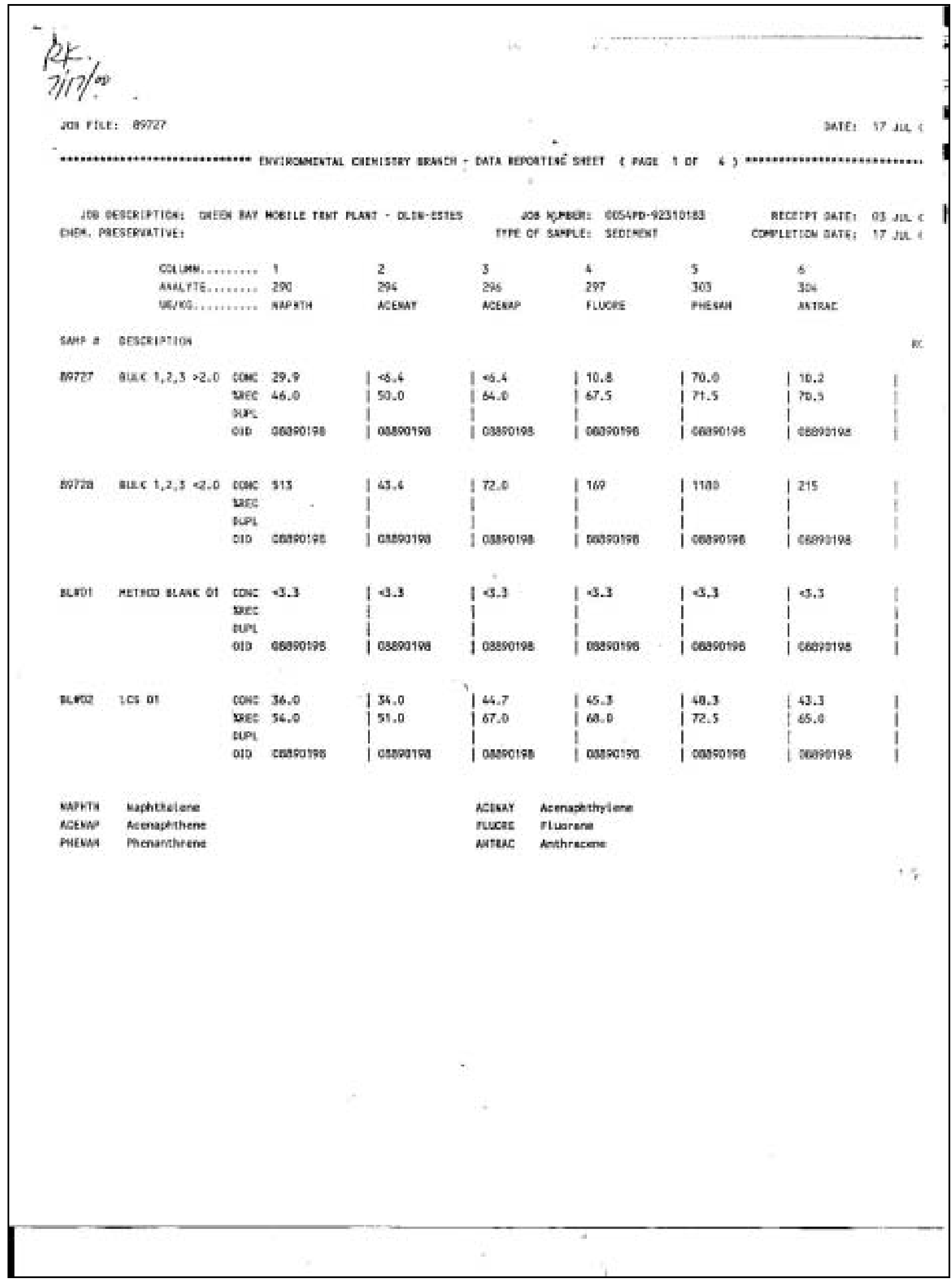




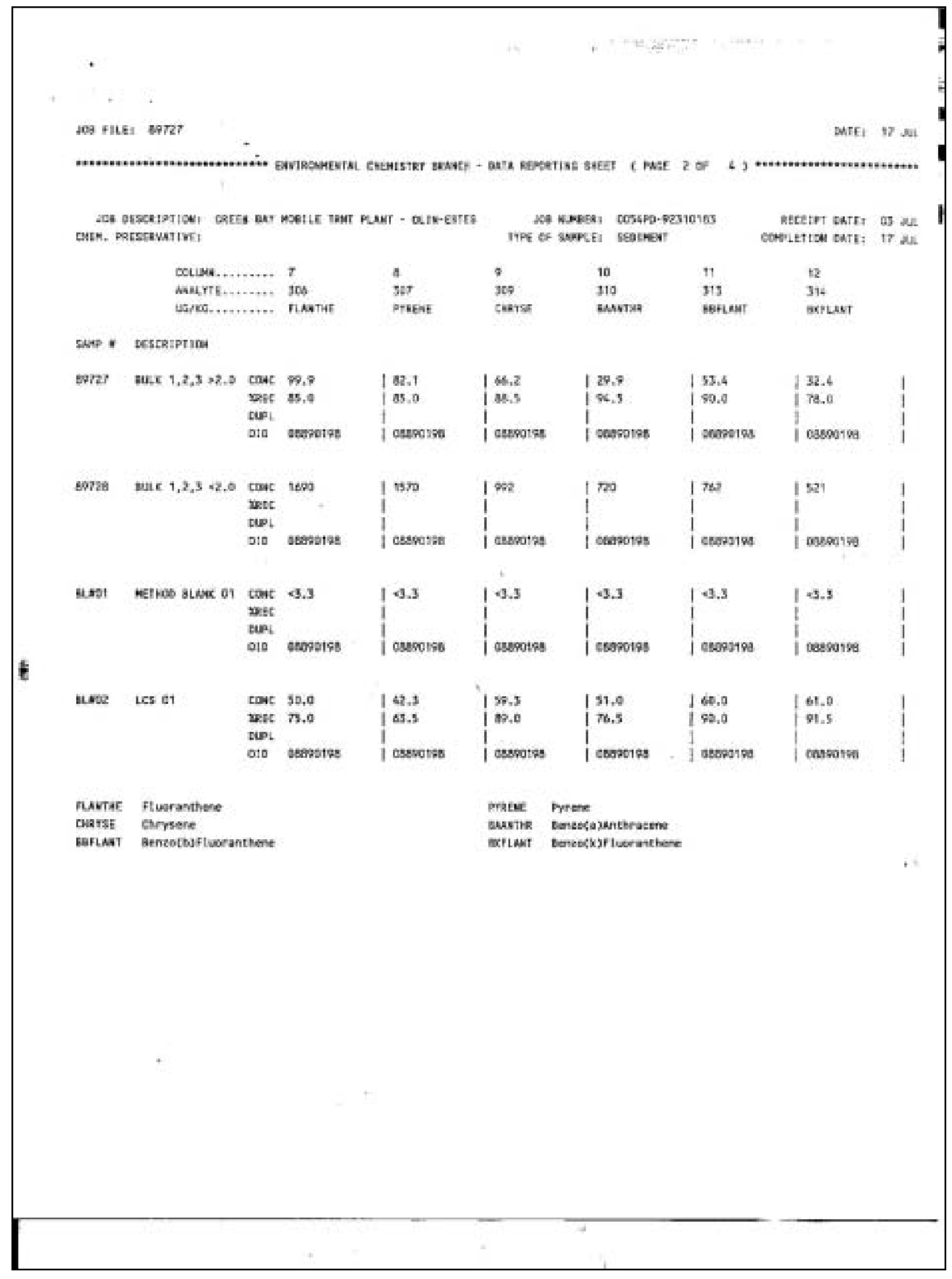




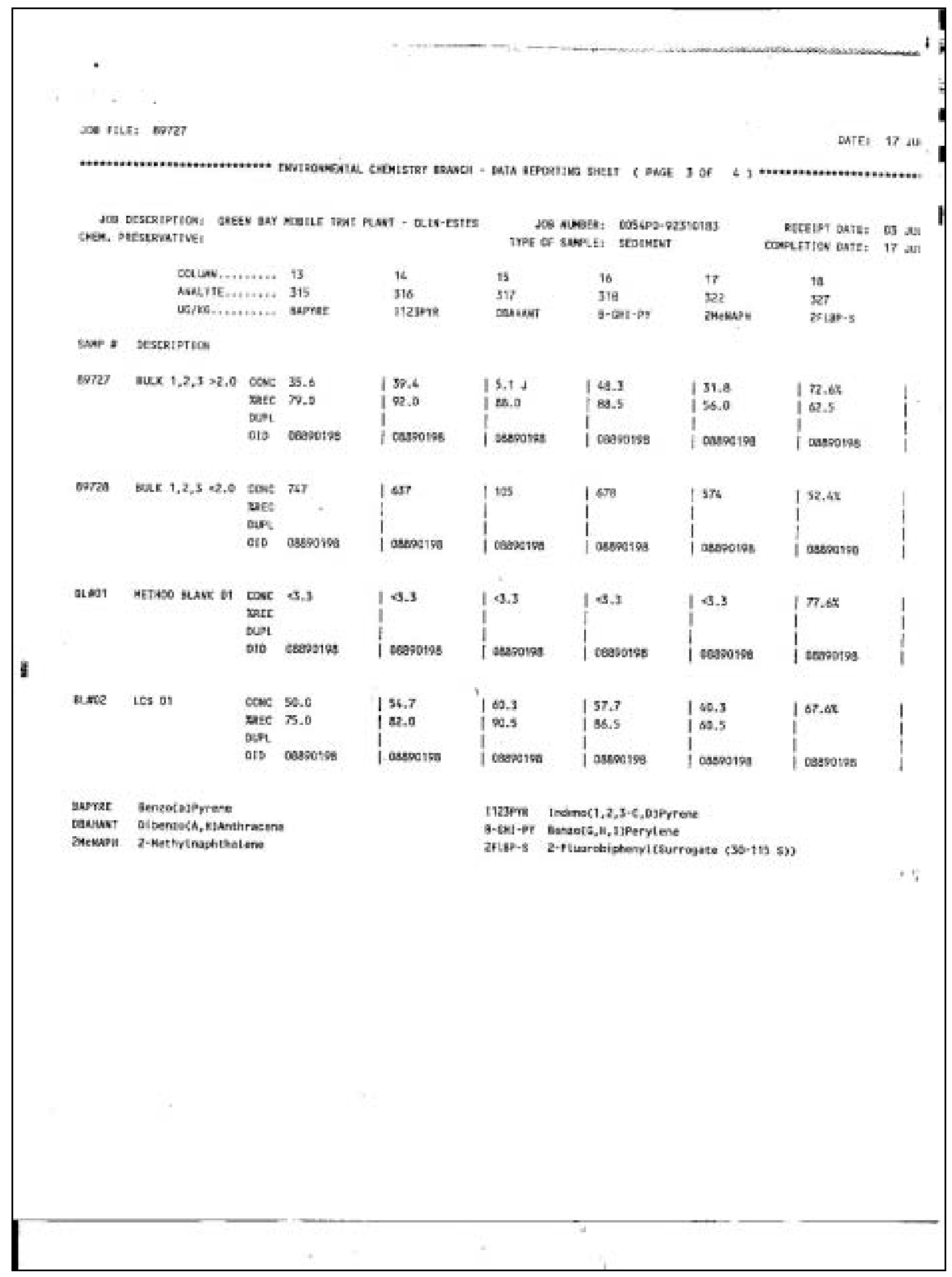




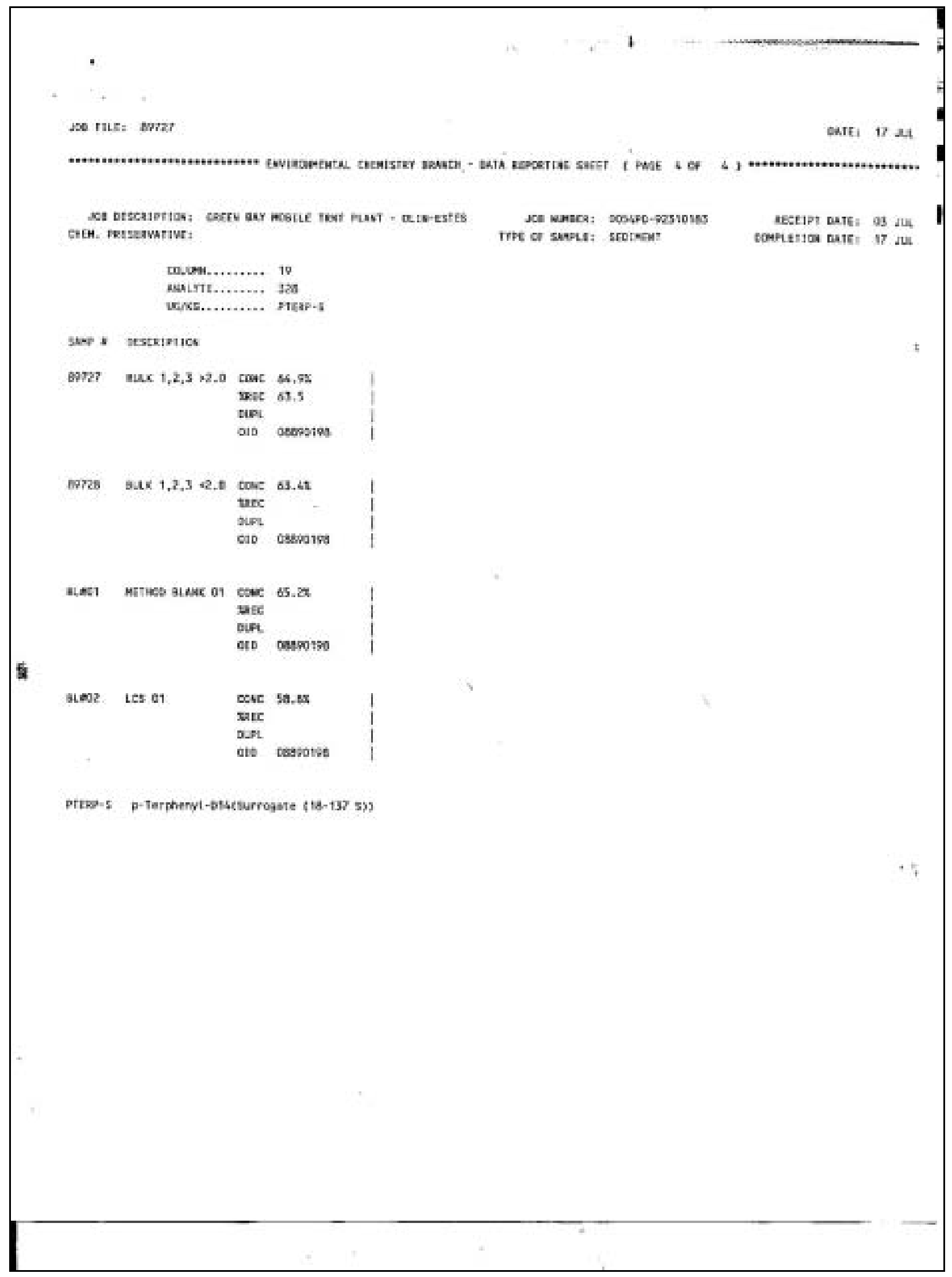




\section{INTERNAL QC DATA}

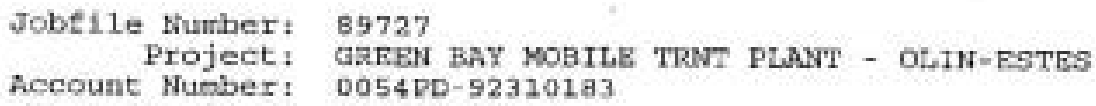

63.5

56,0

49.5

67,5

67,5

73.5

73.0

98.0

88. 5

89.5

96.0

90.0

74.0

84.0

87. 0

81.5

82.5

66.0

69.0

63.9

(a....

19.6

1. 0

5.3

0.0

2. $\mathrm{B}$

3.5

14.2

4.0

1.1

1.6

0,0

5.3

6.1

5.6

7.7

7,0

16,4

9.9

D. 6 


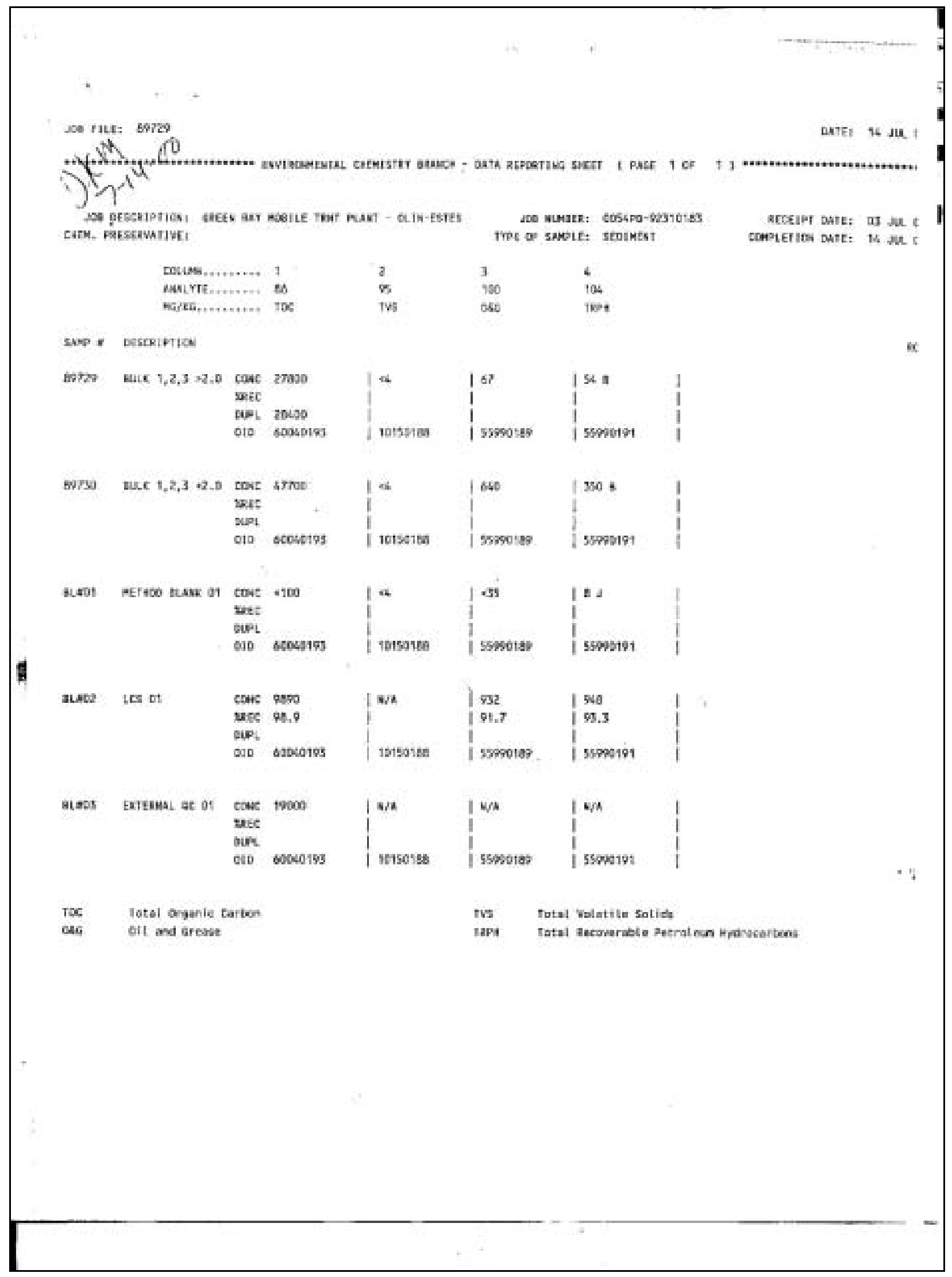




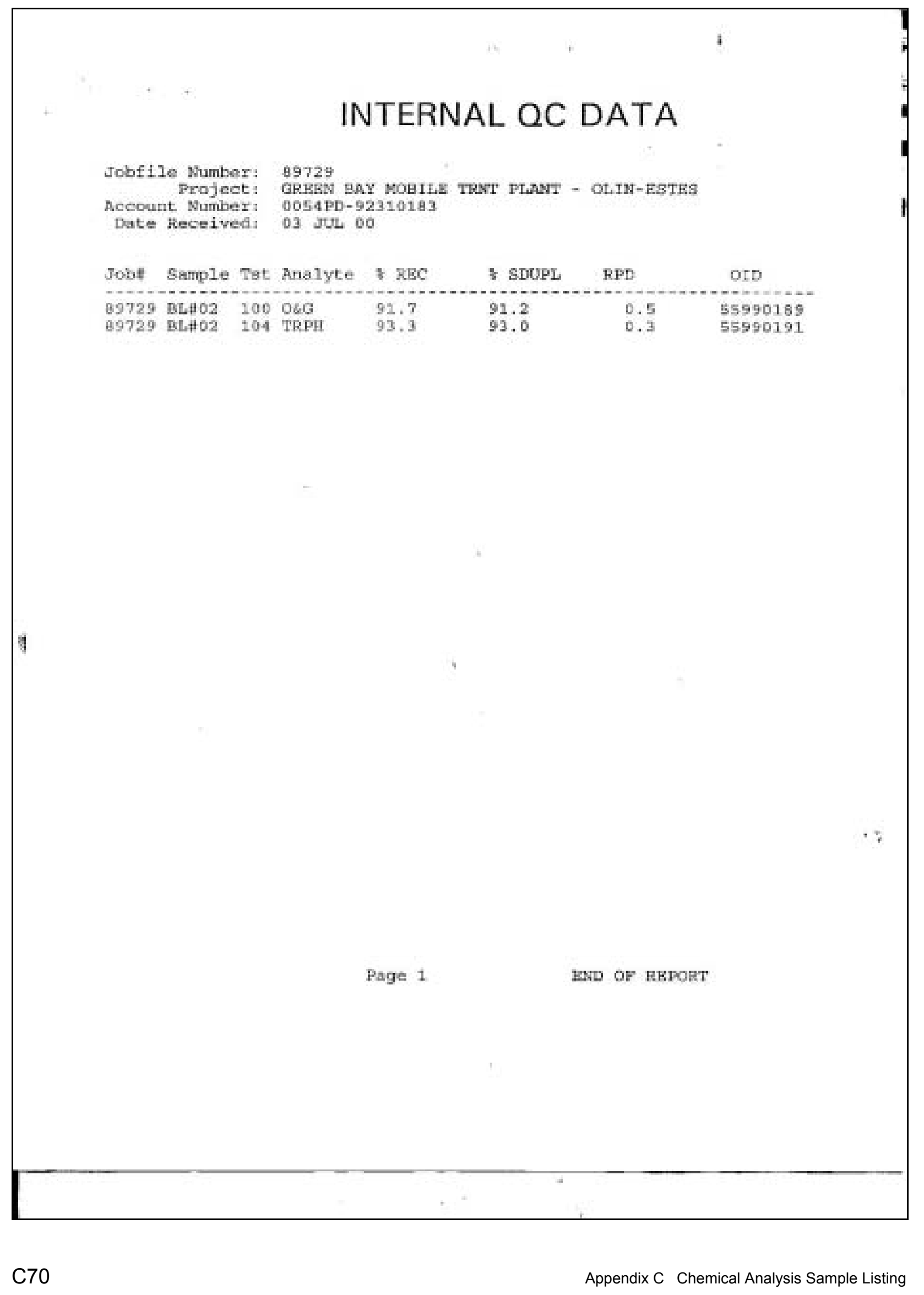




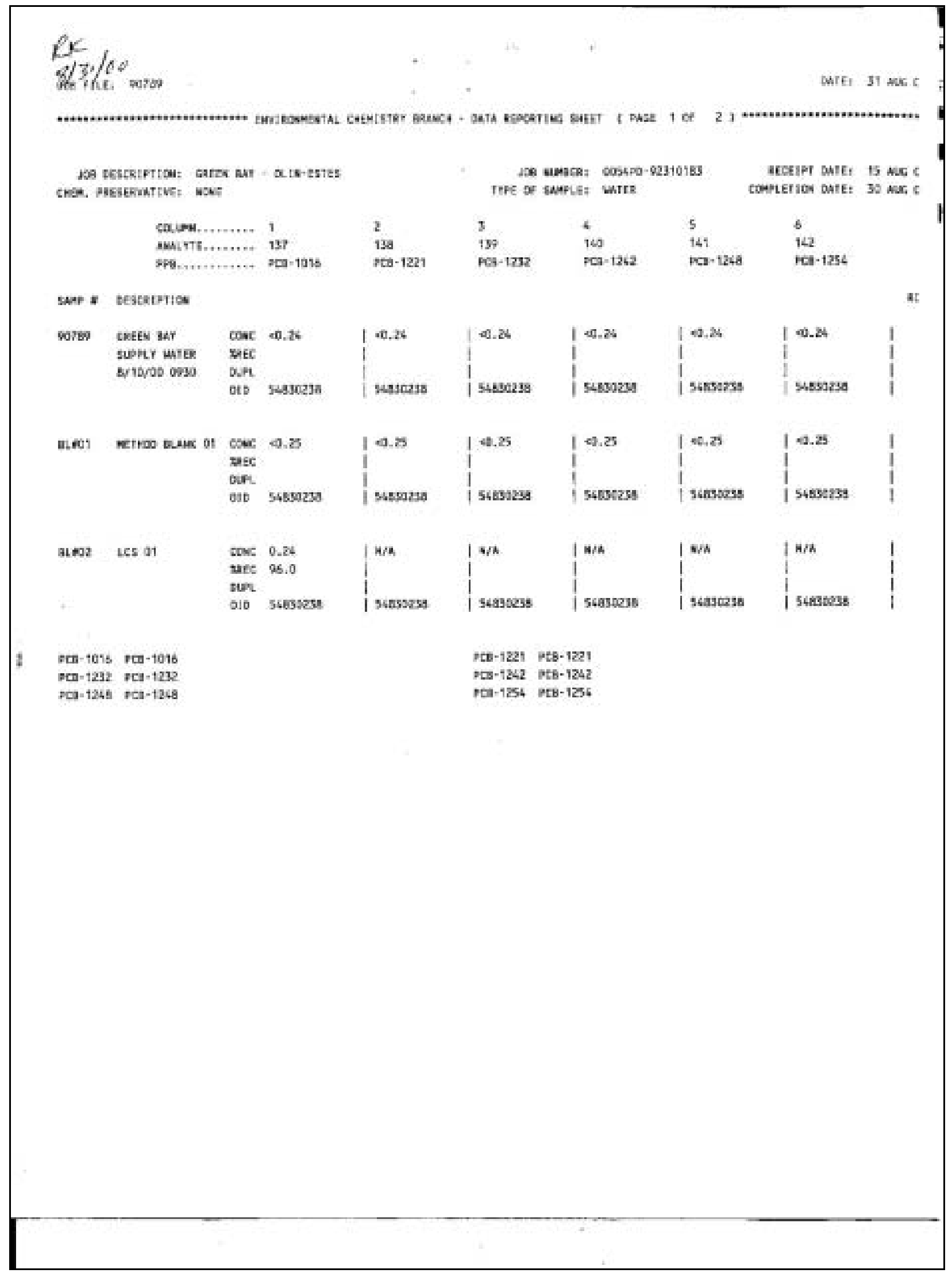




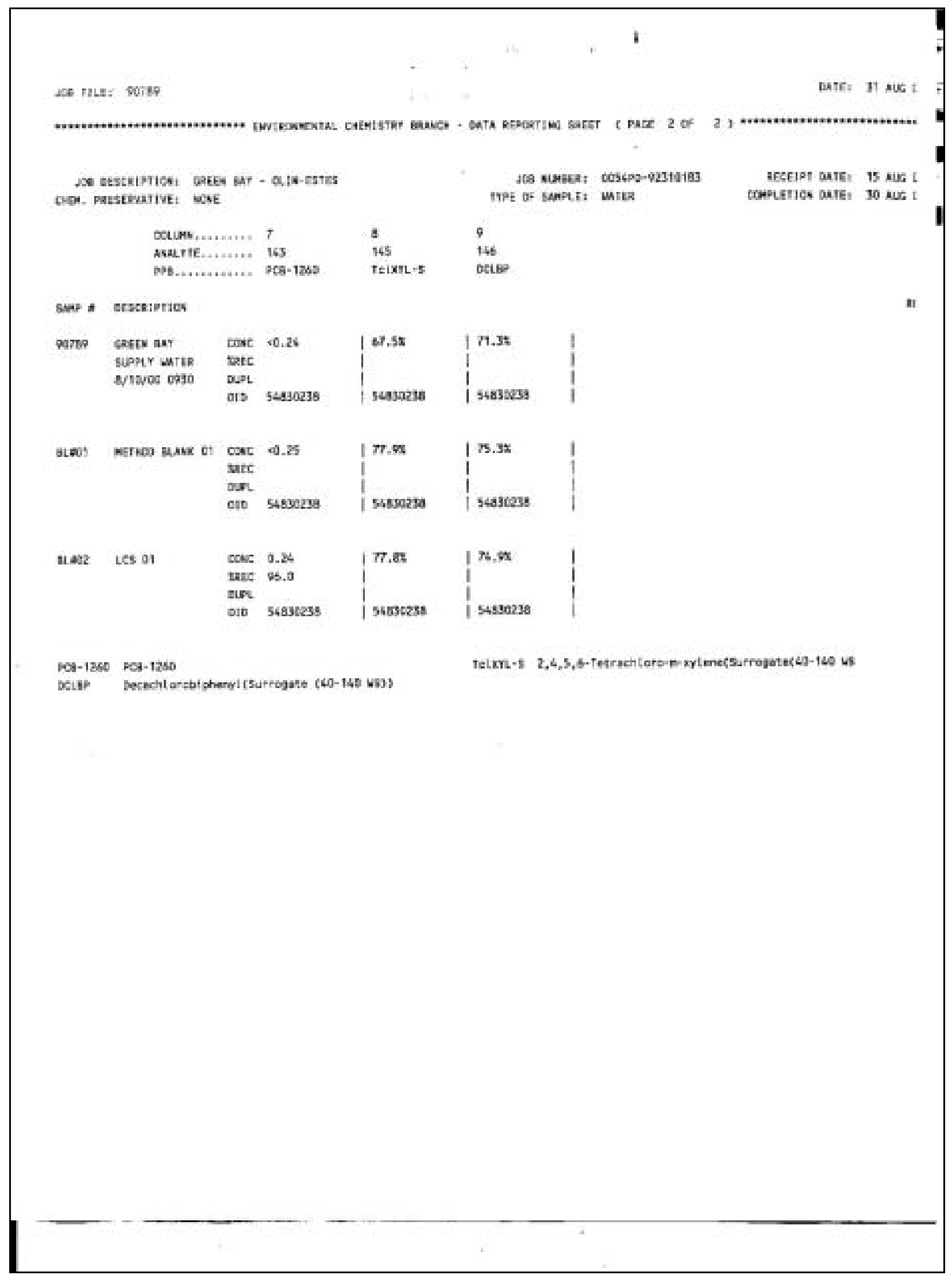




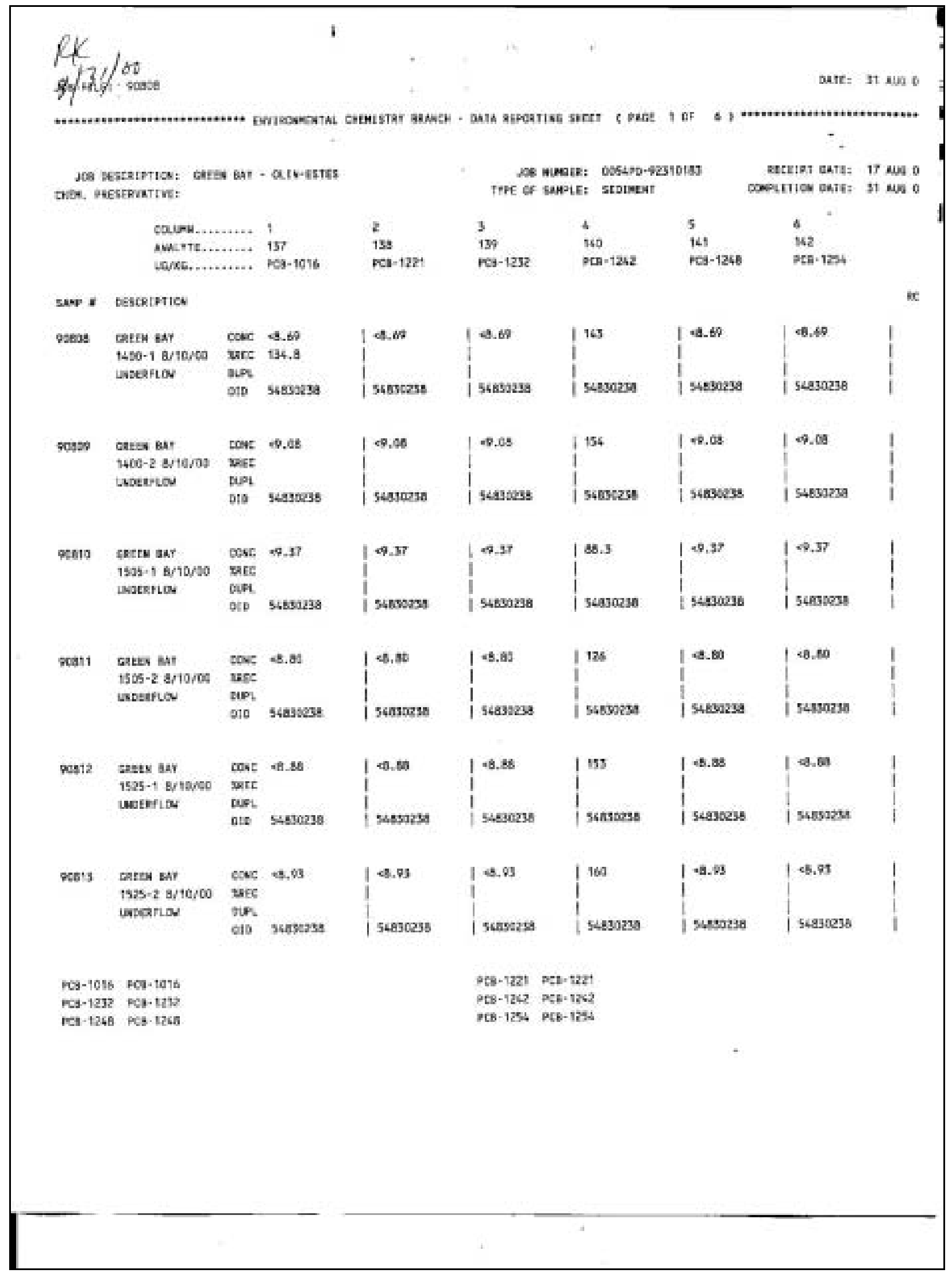


N.w.

Joe arsceiptios: Gates Bat + o.tW-ESTES

c*es. Parstavertivt:

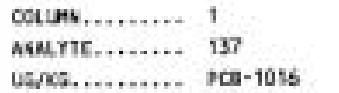

usneg............ nca-10ss
2

139

$108-1221$

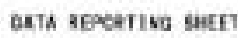

-

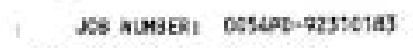

Eecrivt Date: 17 AUE I COAL rTION DATE: 31 aUo I

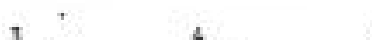

PCB-125?

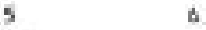

या 142

PCE-17G PCa-1256
340

PCE-424?

Lave = CEscajpries

\begin{tabular}{|c|c|c|}
\hline GAEES Bar & enat & 49.21 \\
\hline $1625-13 / 10 / 00$ & WSE & \\
\hline unbeaflow & tUPL & \\
\hline & 019 & 36930038 \\
\hline
\end{tabular}

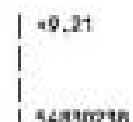

| 9.21

I

| 1695005

$\sec 1$

$$
\begin{array}{ll}
\text { chees asr } & \text { cowc } \\
\text { nes-2 artwos } & \text { weEc } \\
\text { undeurce } & \text { duet } \\
& \text { olo }
\end{array}
$$

\begin{tabular}{|c|c|}
\hline Dês & 40.00 \\
\hline Wate & \\
\hline$x>i$ & \\
\hline ers & 54937230 \\
\hline
\end{tabular}

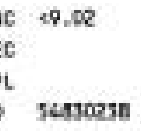

gosis gaves an $1715=1$ sy:0v00 esoenrex

| 4h. i I Sexsaza
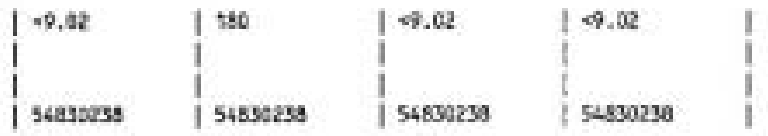

yosi7 ceeE aar $1715-2$ B/10000 uxoenfou

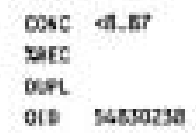
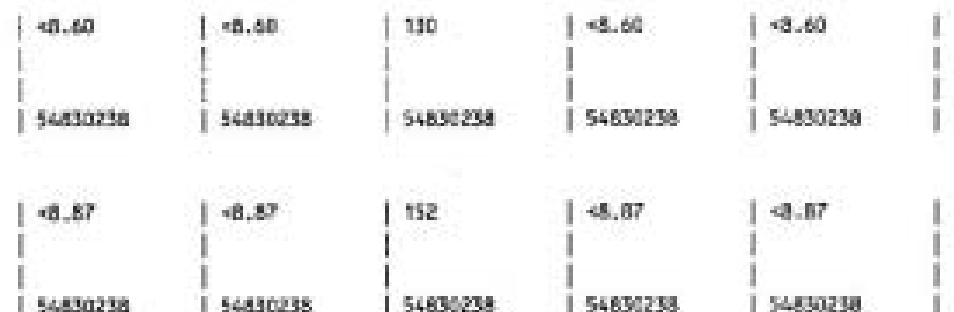

908

$$
\begin{aligned}
& \begin{array}{l}
\text { coes aar Feto } \\
\text { 1405-1 B }
\end{array} \\
& \text { canc } \times 28.3 \\
& \text { xatc } \\
& \text { o:s saser24 }
\end{aligned}
$$

| *15.3$$
\text { I }
$$
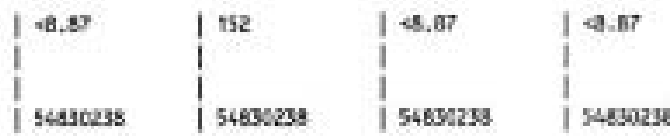

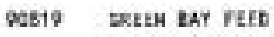
1Sa1 1 a/10reo

conc e17.4
2aec
oub
cis s485123a<smiles>[Mg][Mg]</smiles>

pes-7DTs pce-1ats PCB-1ERE PCB-125? PCB-12LS PCB-1244
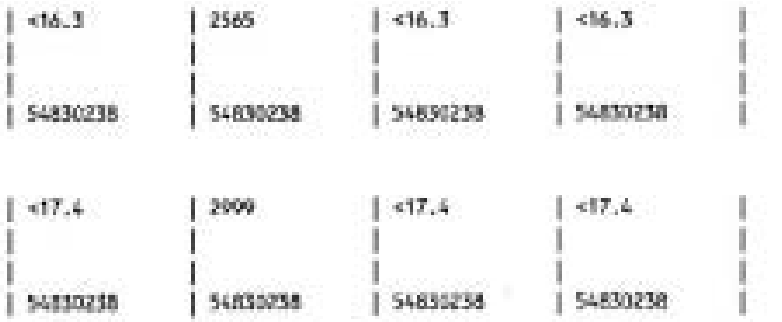

$P C 8-1221 \quad P C 8-1221$

$\mathrm{PCO}-1242$ PC8-124?

na-1254 268-1254 


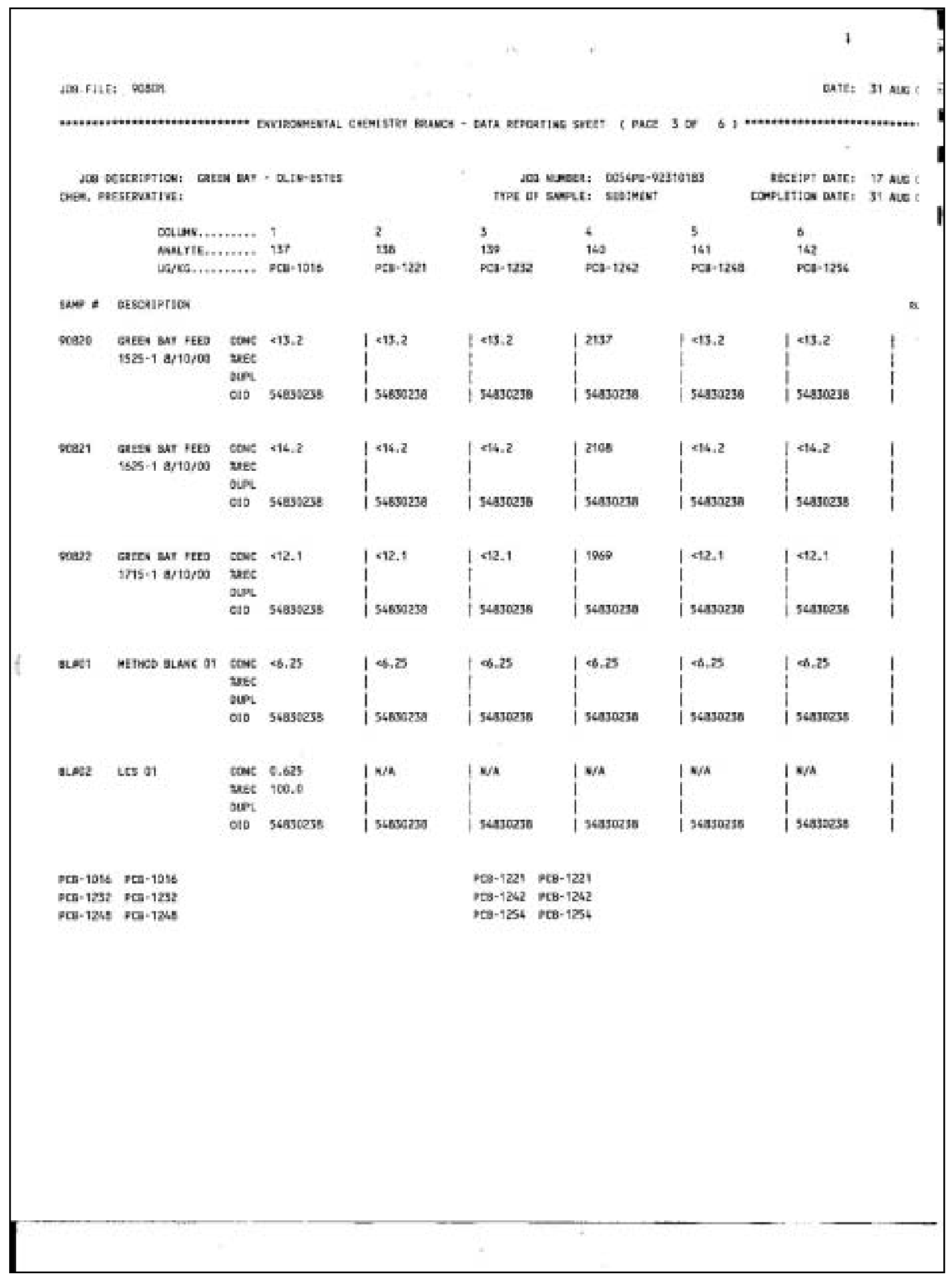




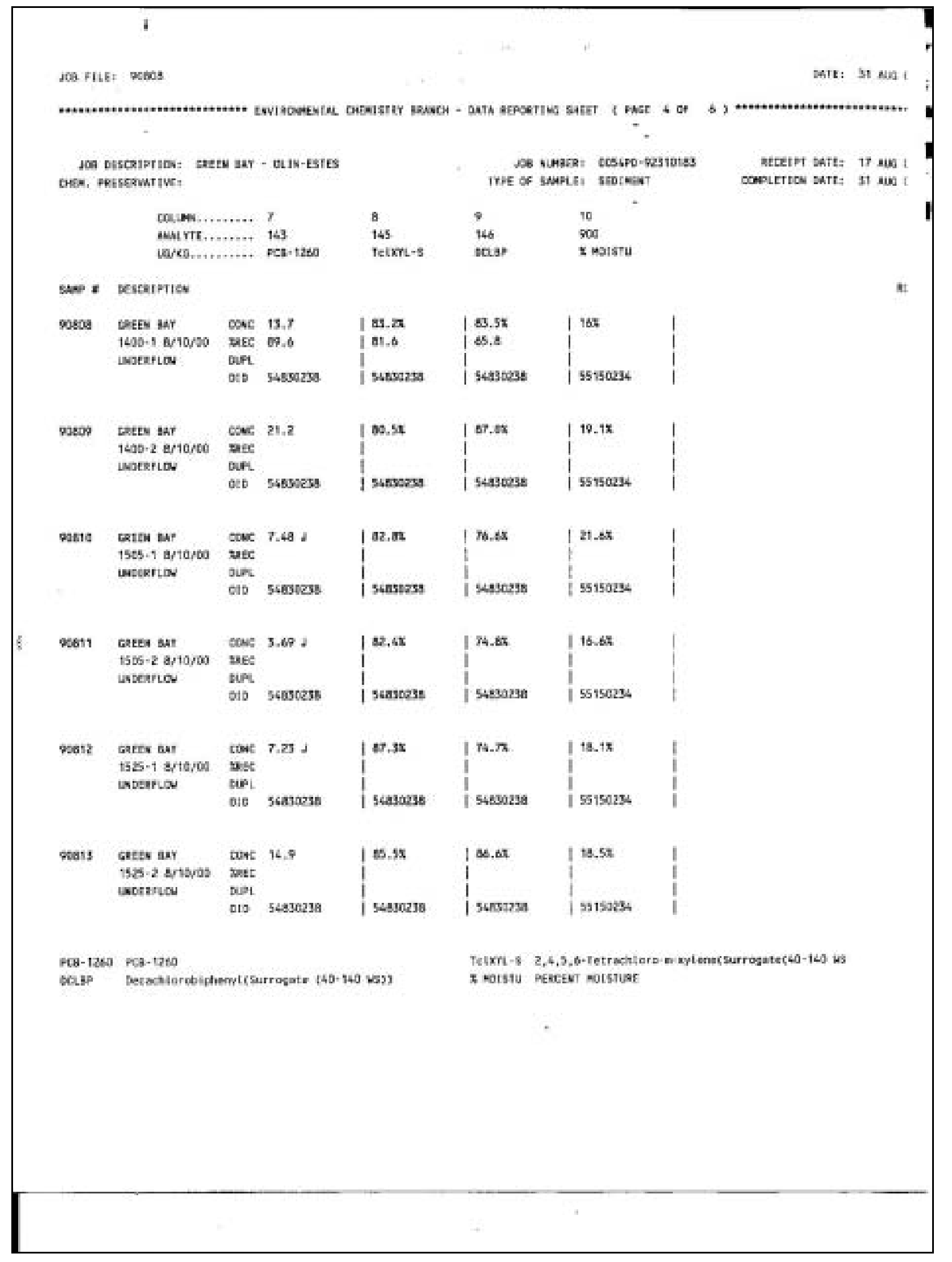




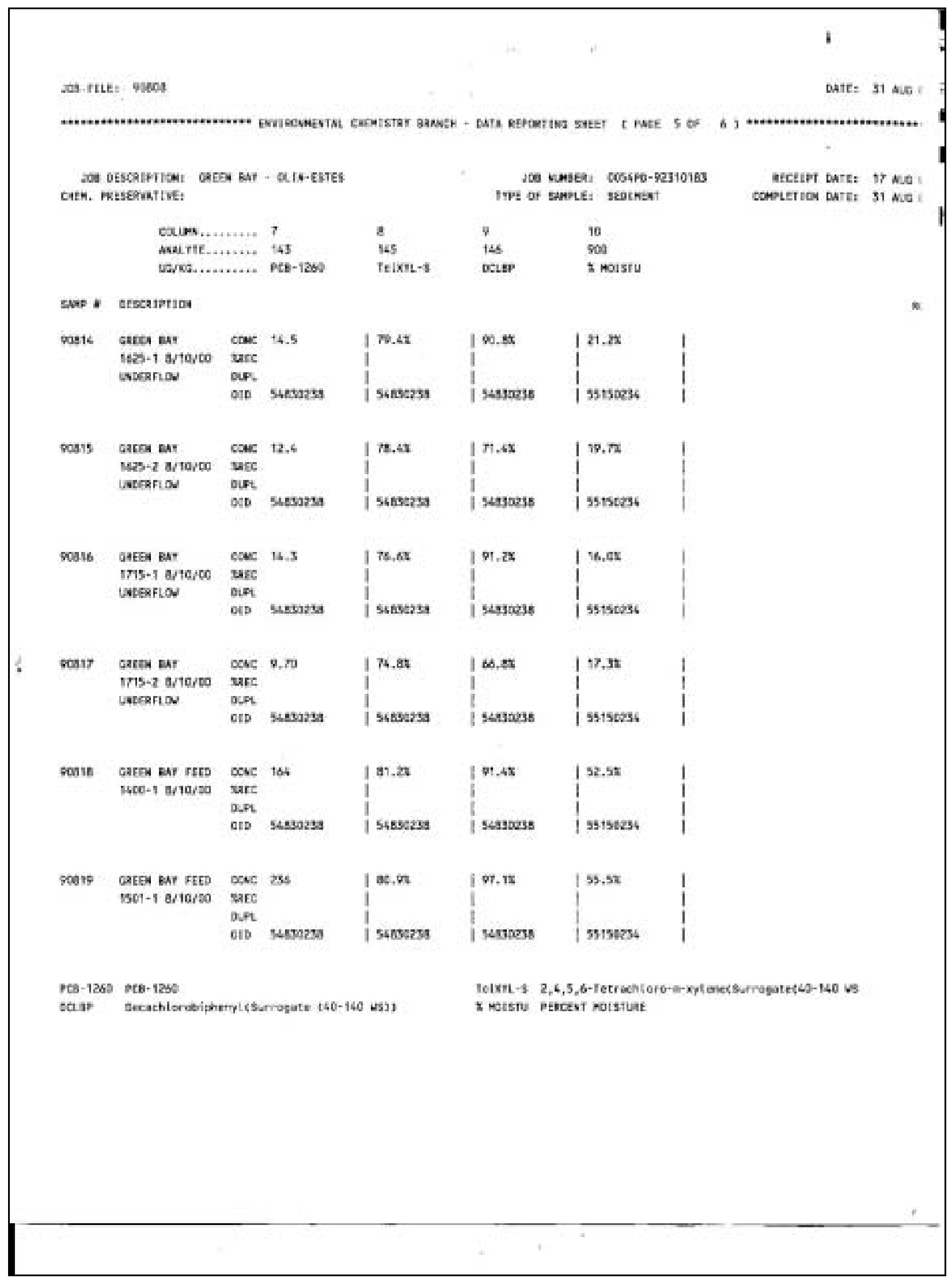




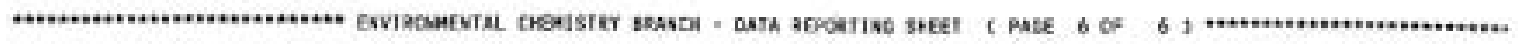

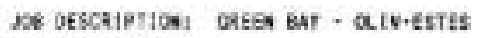
crex. Messeavaltiv:

$$
\begin{aligned}
& \text { Colins............ ? } \\
& \text { akairfe........ } 143 \\
& \text { varke........... pes - 12ba }
\end{aligned}
$$

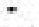

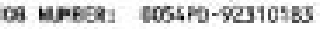
TYPE of sAathe: seines?

AtCIST DAREI IT WUE I

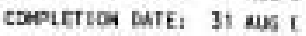

SANP I Descentics

879

16514590

TEIXIL-g BCLEP

9osente
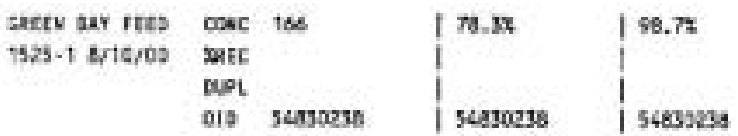

1. 67.18

1

54833239

| 25190236

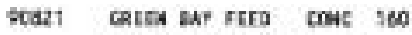

to2s-1 a/10/c0 yef

BU.

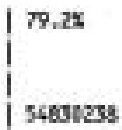

| 86.2a

1

I

154:30238

$166,5 x$

1

sstsoest
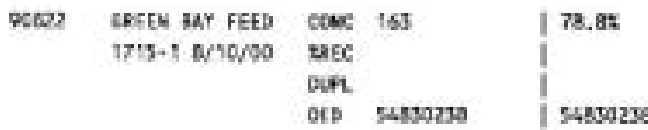

1 $6.5 x$

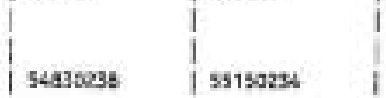

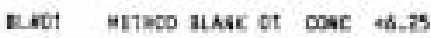

Disc

aipi

alo searoesn

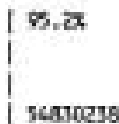

| as. 15

1

scogang

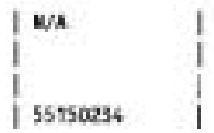

aLdide LCE a1

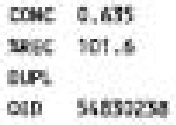

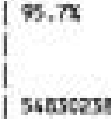

$\left\{\begin{array}{l}\text { a1.35 } \\ \text { s4950236 }\end{array}\right.$

$\mid$\begin{tabular}{l|} 
SR/A \\
55150254
\end{tabular}

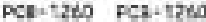

DELEP Decastiorobipherrit(8orregate (40-140 45))

felXuL-3 2,4,5,6-Totrachtors-n-xylene(surrogatecL9-14) wS a wastl practw wolstiRe 


\section{INTERNAL QC DATA}

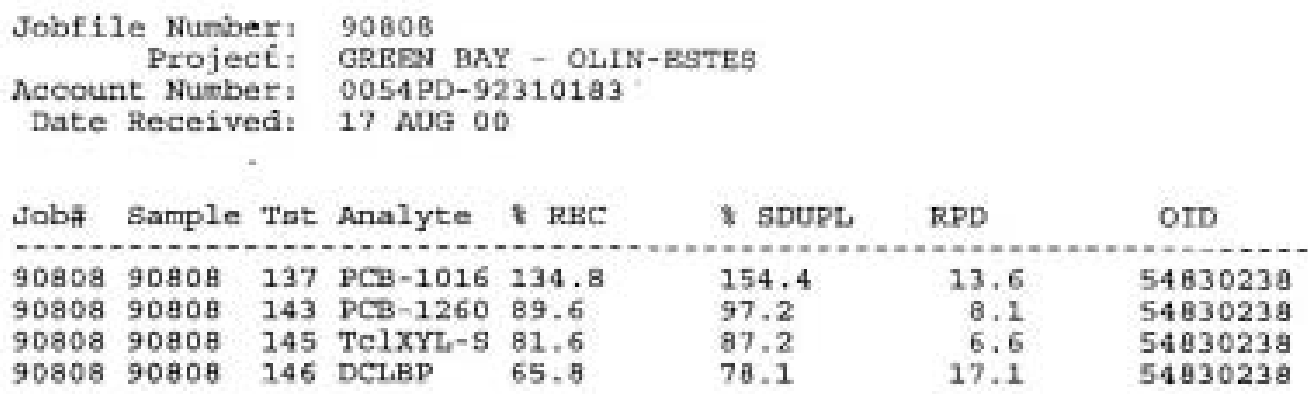

Page I END OF REPORT 


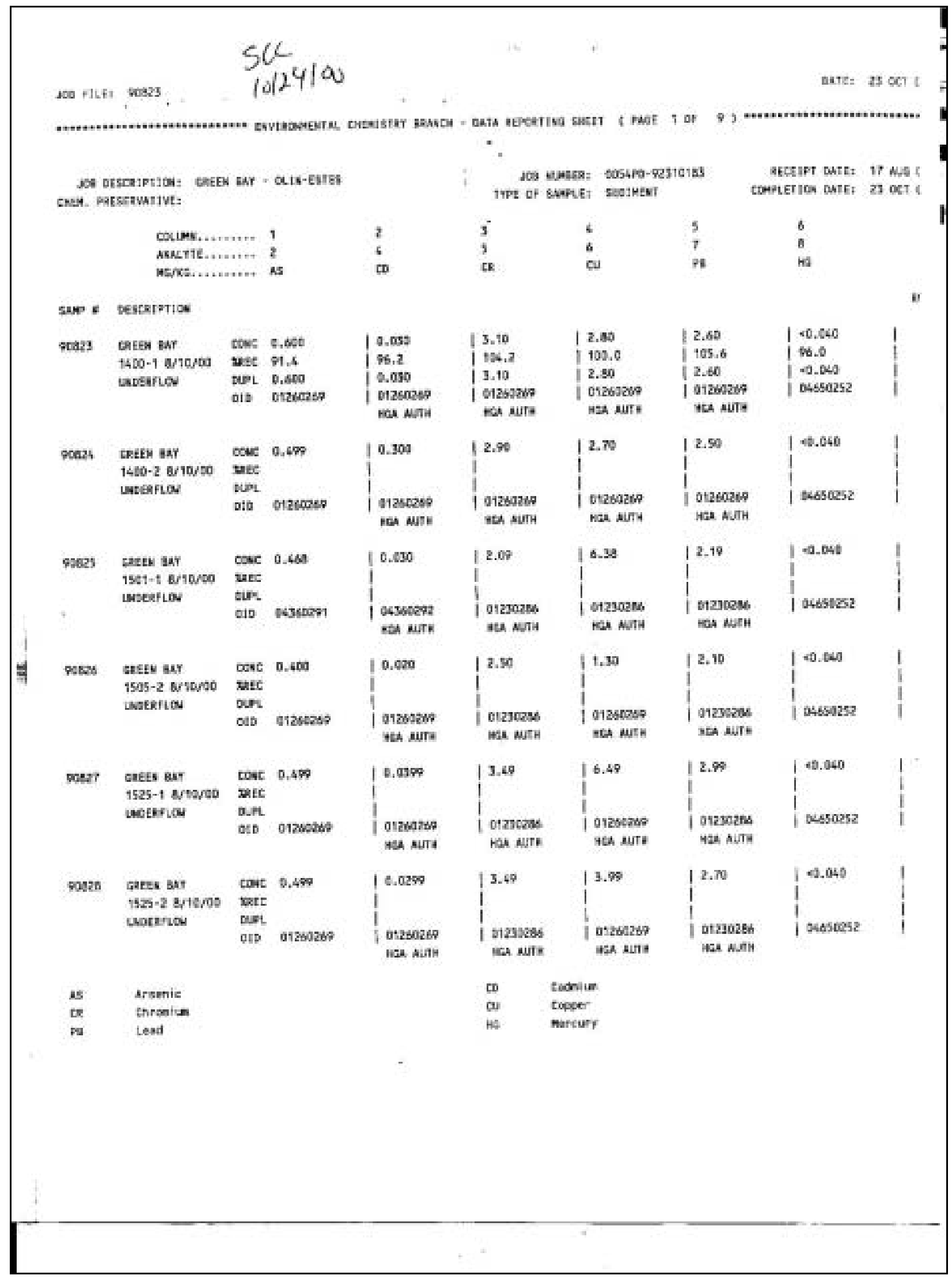


sou nuEi gooss

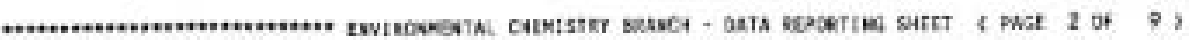

.

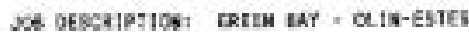
crem. FaEsENATIVE:

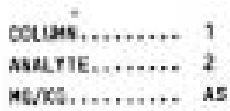

save A tescripito

908

\begin{tabular}{|c|c|c|}
\hline esten say & $\cos c$ & 0,360 \\
\hline $1825-18 / 70 / 00$ & WEE & \\
\hline LWPCRLICS & $602 \mathrm{~L}$ & \\
\hline & ots & 0126azes \\
\hline
\end{tabular}

9องระ

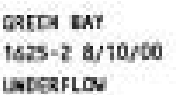

osac 0.5a2

zeEC

ate gro guter

sossi saefs ant cone 6.529

$1715-1$ svtoyos

MeEstou

teet 100.3

oto pessopot

9oses? carrm ar

$1715-2$ \&/10/200

Imerorio

cosc 0,410

vate

oun

acb 04360891

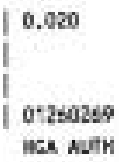

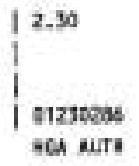

1.20

1

I

1 01250269

sas ayfh

\begin{tabular}{|c|c|}
\hline 0.050 & 3,60 \\
\hline & \\
\hline 04364262 & Dizyozes \\
\hline sta surs & Hat Auth \\
\hline
\end{tabular}

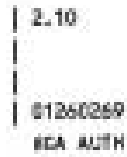

I 2.25

I 97.5

1.60

I 01260269

mak AบTH

04350es2

| $9125 n 26$

4CA जuा

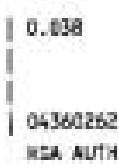

12.33

I

o12300as

not nur
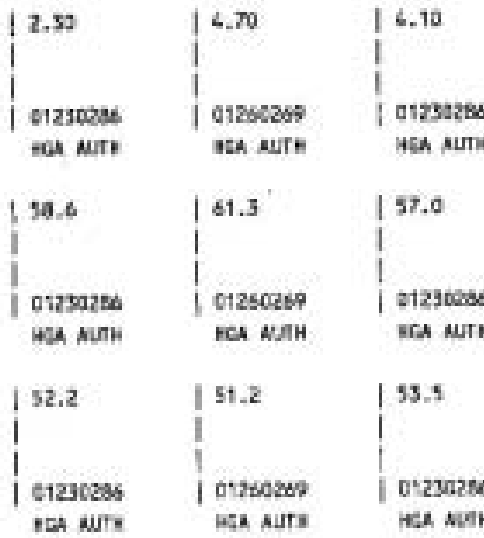

RECIPT DNTE: 17 ALE A COMPLETION DARE: 2T OCT 2

$$
\begin{aligned}
& 8 \\
& 8 \\
& -6
\end{aligned}
$$
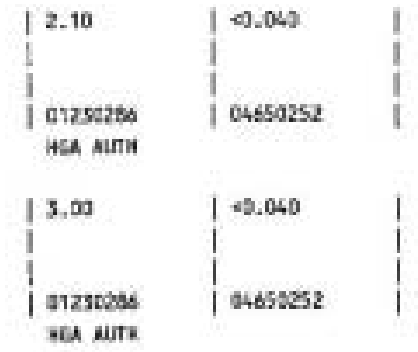

1.5 .040

I

I

| 44650es2

5,09

1 109,0

6,59

I orzscoss

Mas Numn

| $=0.640$

| 56.0

I 0.040

| 04650252

16.10

I

i

| arzsazes

4ธA ง

10.000

1

104650252

157.0

I

I

| 21230eses

sca nute.

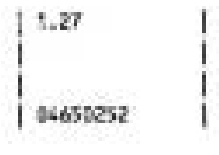

906Y EREN aAY nest cost 3.99

1505-1 nisorec xase

Durt

ato 04360291

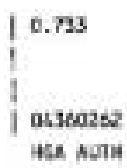

$\mathrm{CD}$

cadriun

copper

Mereury
As Arstonic

Fo Lead

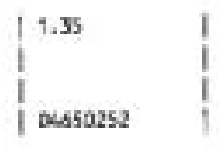




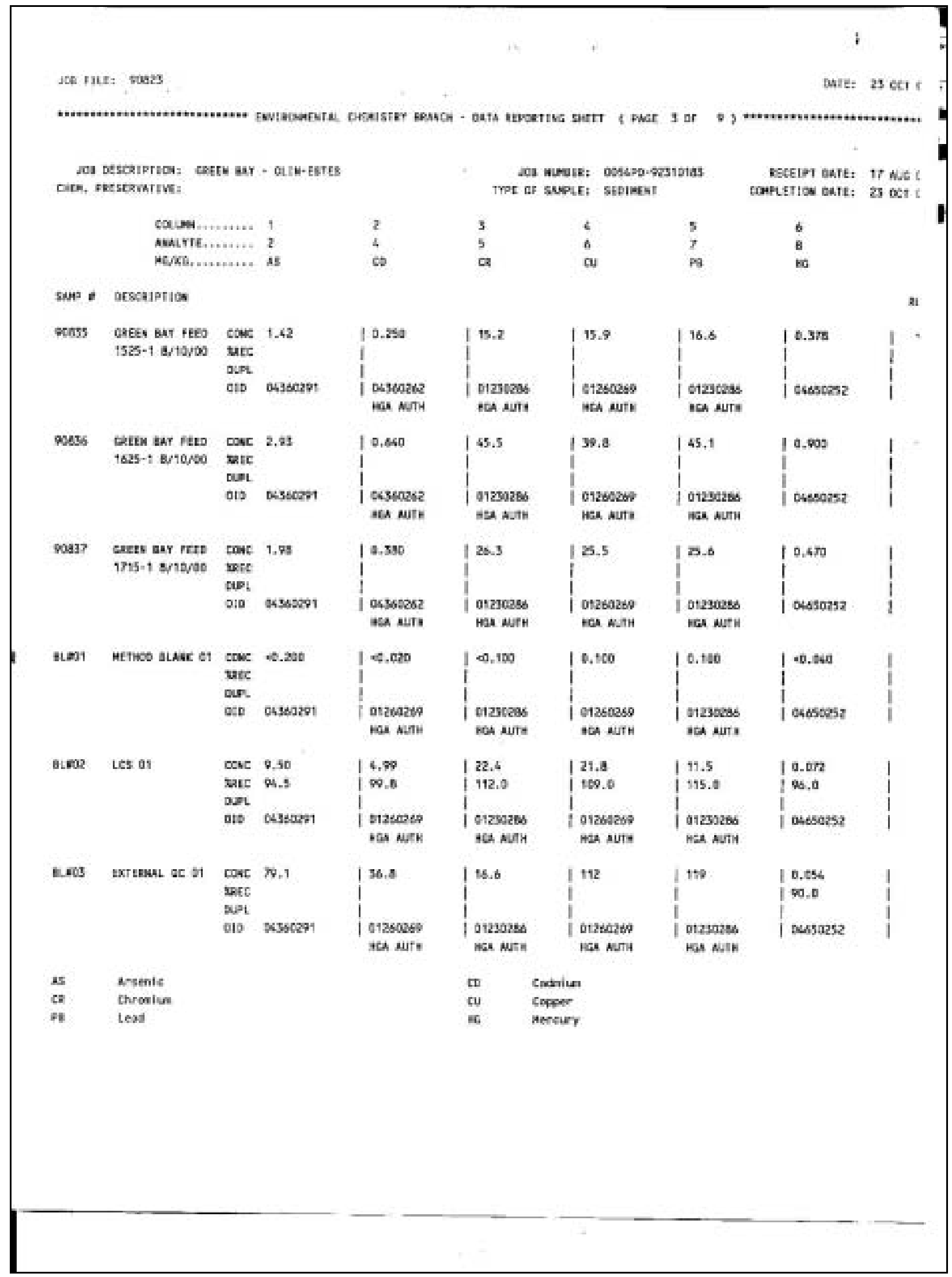




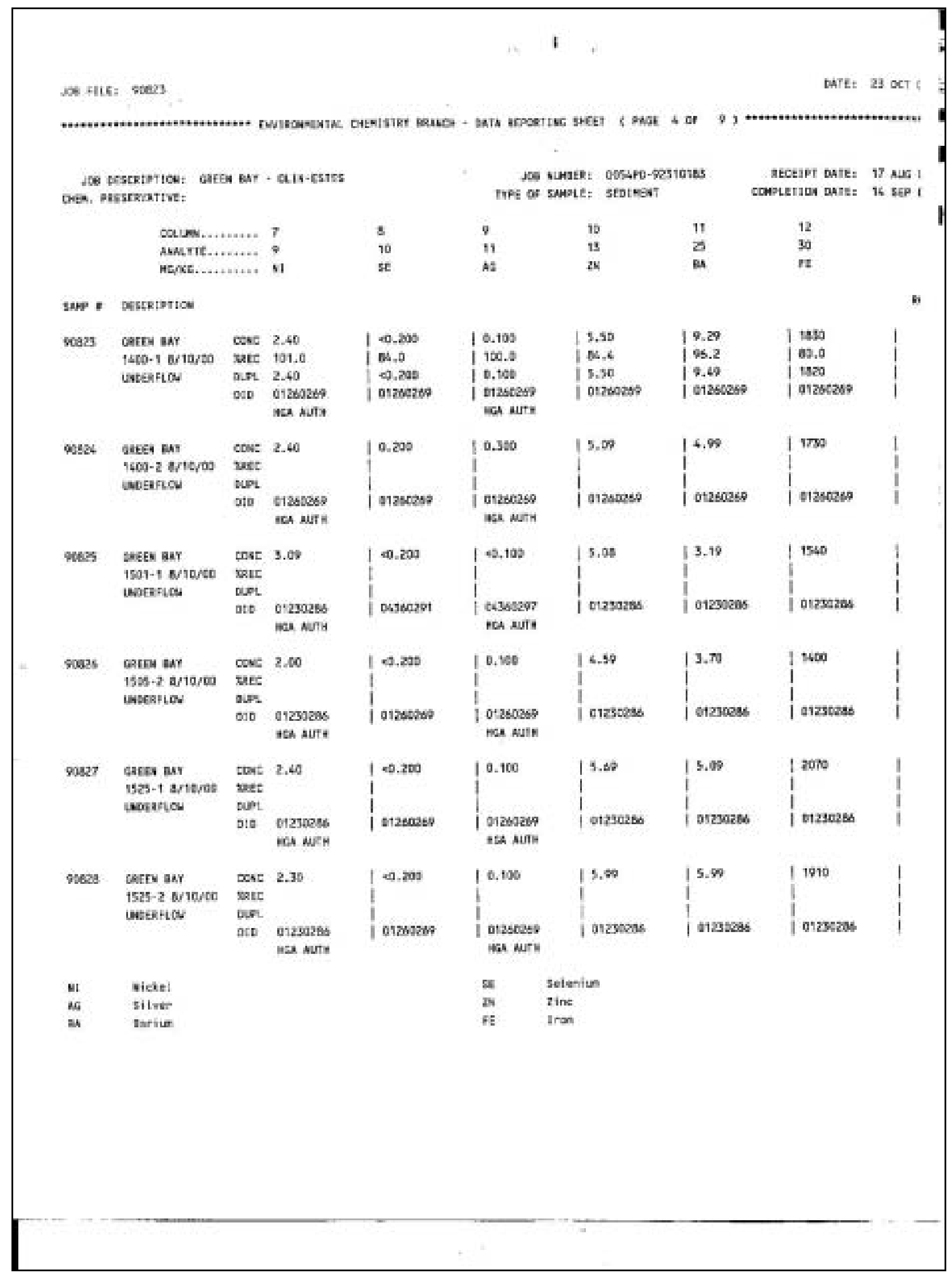


Jos ALE: wo2s

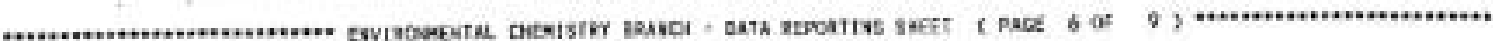

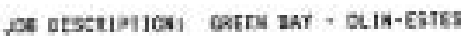

$$
\begin{aligned}
& \text { COLUE,.......? } 7 \\
& \text { AsaLTTE. } \\
& \text { MtoxE } \\
& 8
\end{aligned}
$$
che4. parseknativet

$\operatorname{sav}=$ Dsscentice

yoess Gara Ear ree $158-1$ a $/ 10 / 00$

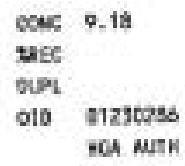

ELEED OATEI 17 ALE I CONLETIOE AaYE: $1650 \mathrm{i}$

$\rightarrow$

11

ac

10
13
24

11

bs

12
35

30

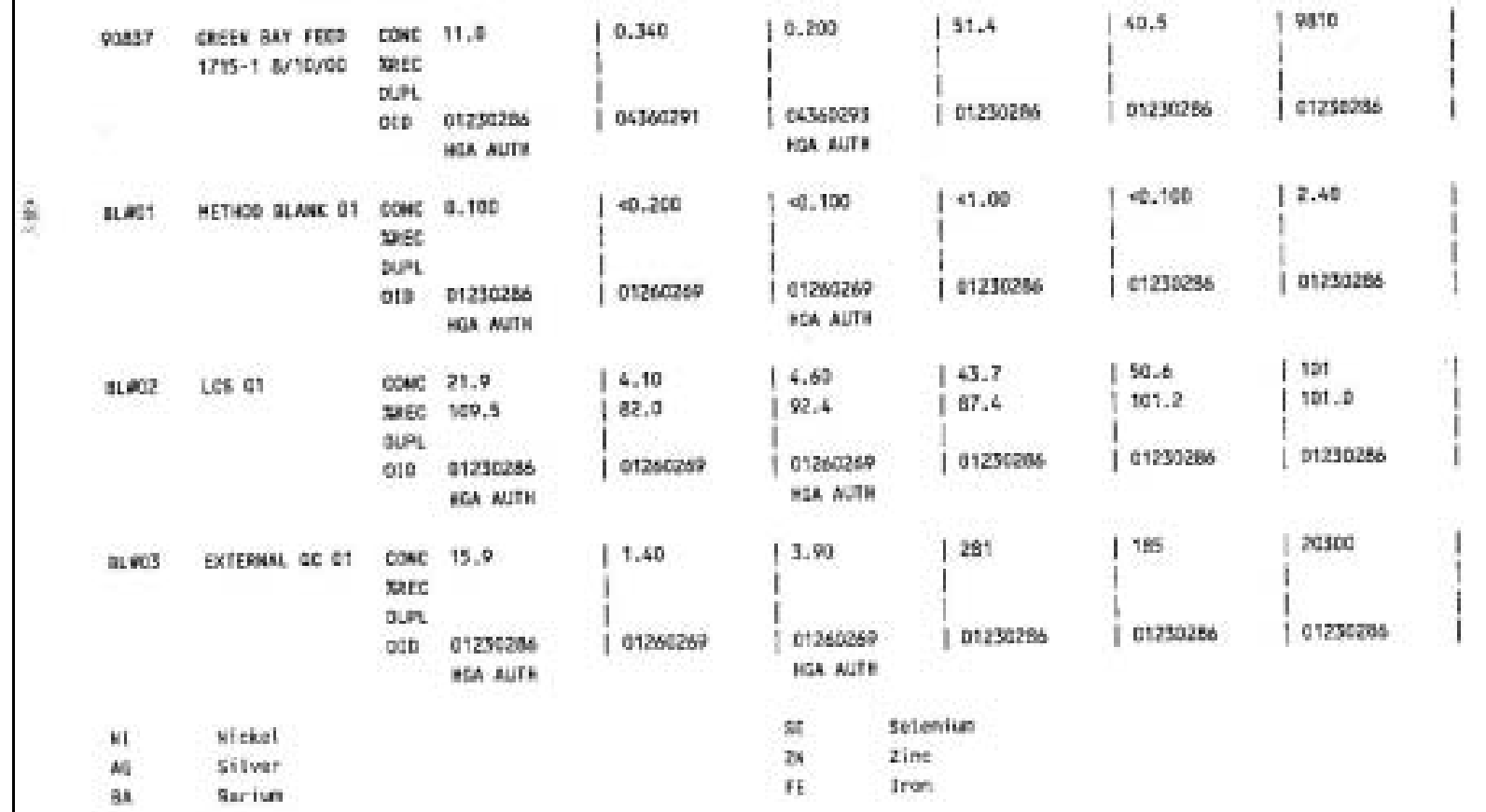


sos fit: 98021

Eate: 23 oct it

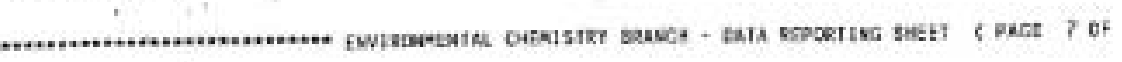

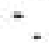

do cesceipticer gates sat - $\alpha$ is itstes CHEk, vaesekrartusi

i99 vuses: 6054F0-92310483

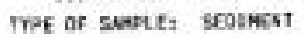

GECEIPT DNTEI IT NWO I

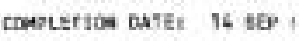

\begin{tabular}{|c|c|}
\hline $\cos u$ w.......... & 13 \\
\hline watrte, ,...... & 32 \\
\hline $\mathrm{marc0} \ldots \ldots+\ldots+$ & Na \\
\hline
\end{tabular}

SA4P $z$ arsceiprion

90625

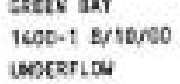

\begin{tabular}{|c|c|}
\hline cose & 48,8 \\
\hline$x 25$ & W.D \\
\hline ospt & 64.3 \\
\hline OCD & 01200260 \\
\hline
\end{tabular}

woses aAere an:

$9606-2$ srtopos raf woestion Dat ore c1250260 แบa avth

50925 caeed BNT 1501-1 ertapos sueksiou $\cos 36.9$ wet wat er) D1230256

$$
10.100
$$

I 102.2

| D.160

| oszazto

2

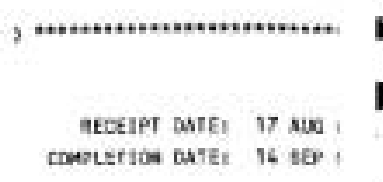

$\left.\right|_{1} ^{0.100} \mid$

$\begin{cases}47,00 & 1 \\ 01260260 & 1\end{cases}$

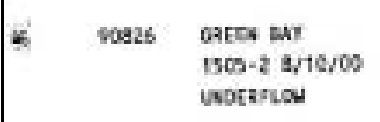

\begin{tabular}{|c|c|c|}
\hline ecke & 44.9 & | 1.02 \\
\hline sock & & I \\
\hline wot & & i \\
\hline 010 & $\begin{array}{l}\text { t1230836 } \\
\text { iar wuth }\end{array}$ & i 01260868 \\
\hline
\end{tabular}

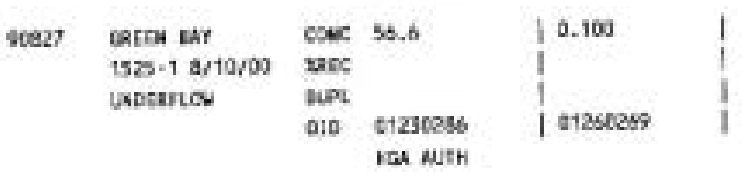

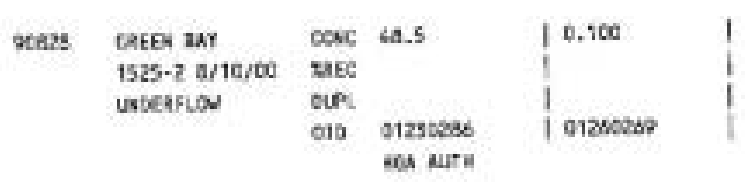
in Mafvarnese
Mo natyodenon 


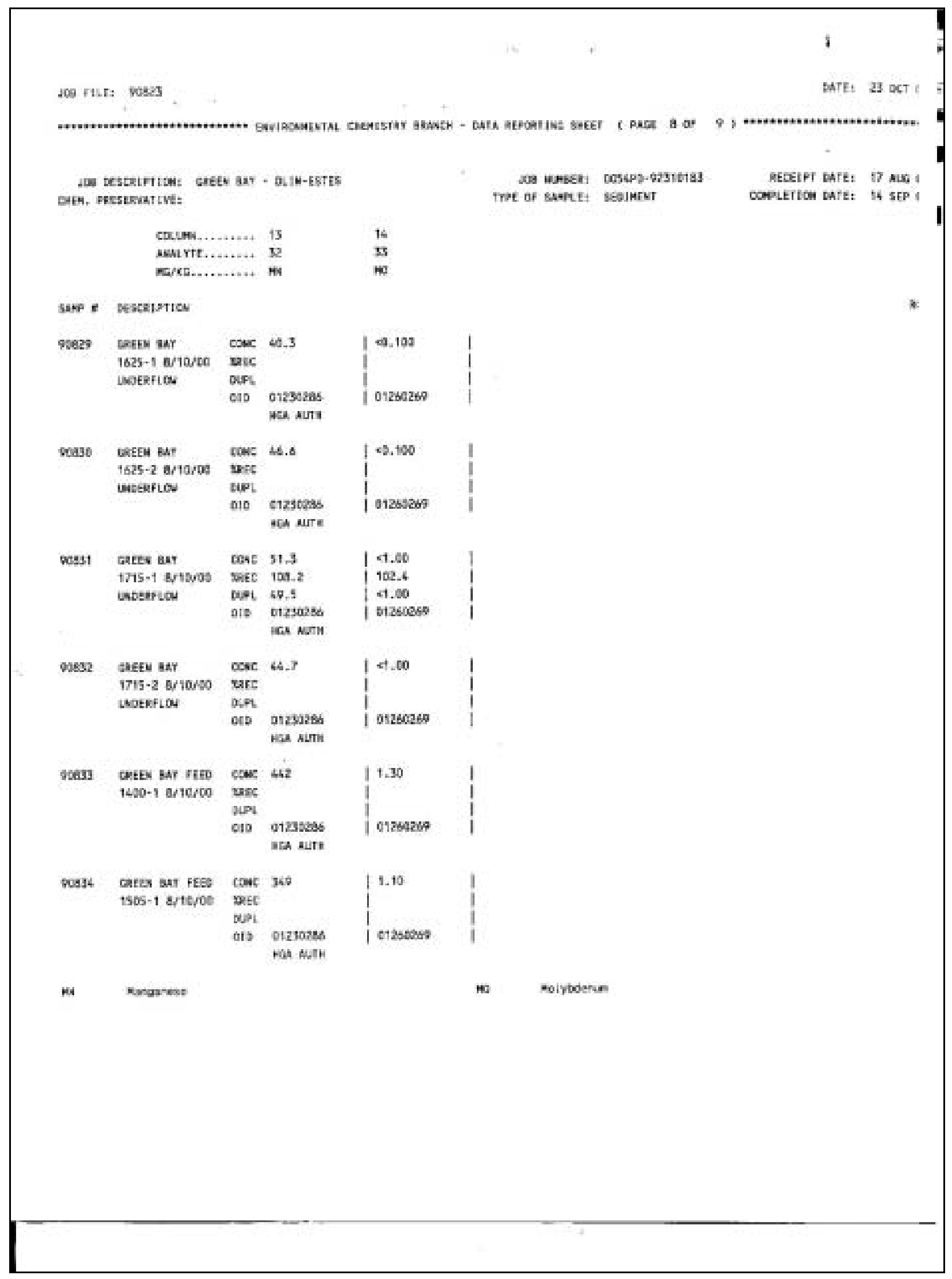




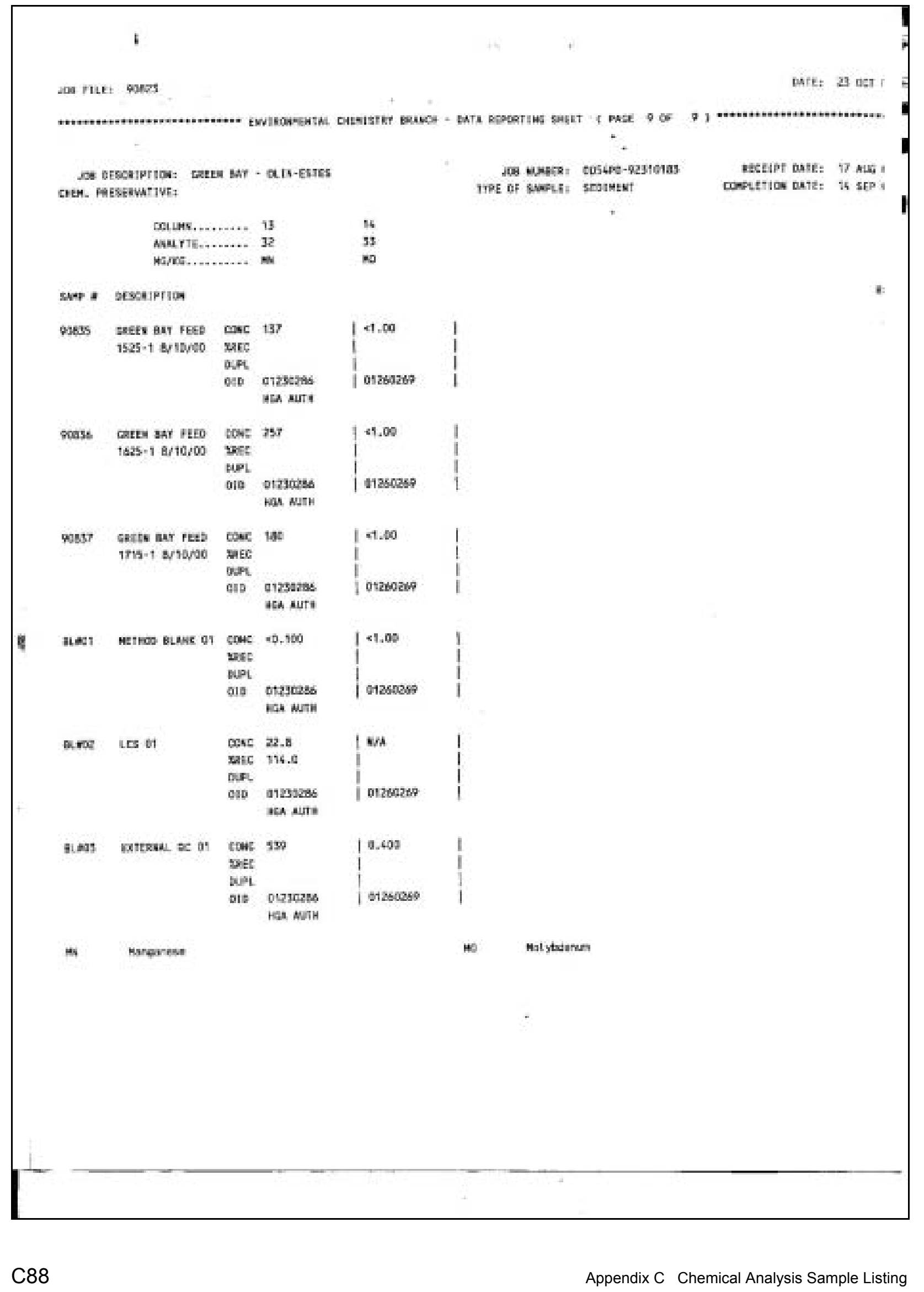




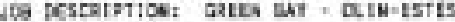
DAER, PEESERETIVE

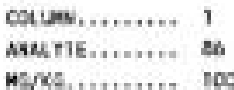

Bav $x$ testriptios

2

TY5 Cर:

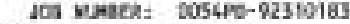
TYPt or sevet: seajuskt

IESEIRT CATEI 17 MS I COALETICE BAfE: 30 ME I

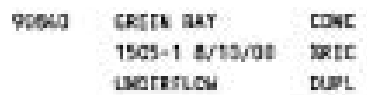

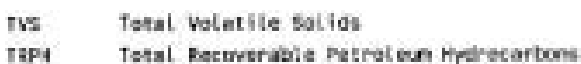


dou nît: posses

DAtE: 32 AuC $t$

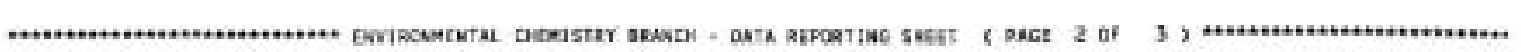

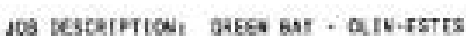
bes. peseccartive:

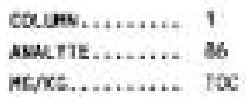

sav * tesceiptios

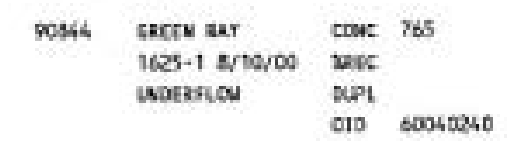

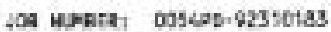

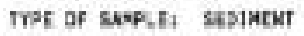

eEteint Dart: 17 aW 6 comefiton sart; 34 wa if

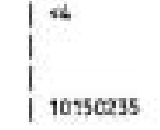

3
100
060

6

106

QS6 TRYM

$\left\{\begin{array}{l}23.04 \\ 55000230\end{array}\right.$

$\left|\begin{array}{l|}045 \\ 55090242\end{array}\right|$

it

gos5 aEet asy
1625-2 evrovos
worapycy

tout 2570
vart
DUPL
CID scosost

$\left.\right|_{1} ^{40}$

9046

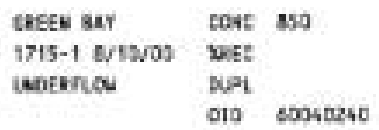

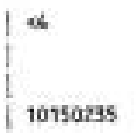

$\left\{\begin{array}{l}50.02 \\ 5500023 \%\end{array}\right.$

QOeC? GKEE BaY

$1715-2$ s/cos

usersion
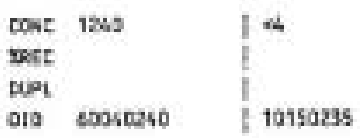

$\left\{\begin{array}{l}10.0 \% \\ 55000230\end{array}\right.$

9004

CEEFV BAT FEES

$1600-1$ Nover
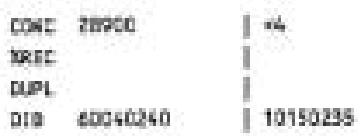

$\left\{\begin{array}{l}48.0 \\ 55000230\end{array}\right.$
QOSL CKEEN BaY FEE COAE JSACO 1505-1 Bupoo

cowe 3asco
bite
wol
ote 60040260

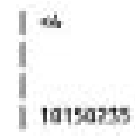

$\left\{\begin{array}{l}460 \\ \mid \text { ssposzos }\end{array}\right.$

Toc Tetal arganie cerbon

ake ais ared aresta

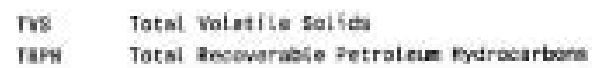
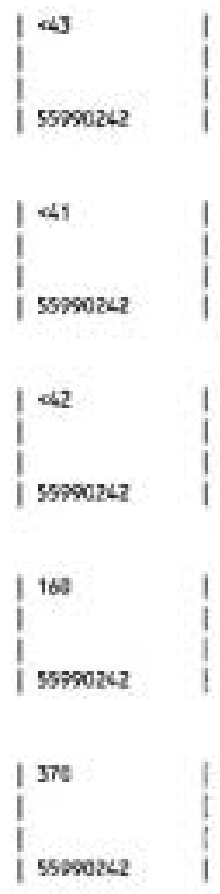

$\mid$\begin{tabular}{l|}
162 \\
$\mid 55790262$
\end{tabular}




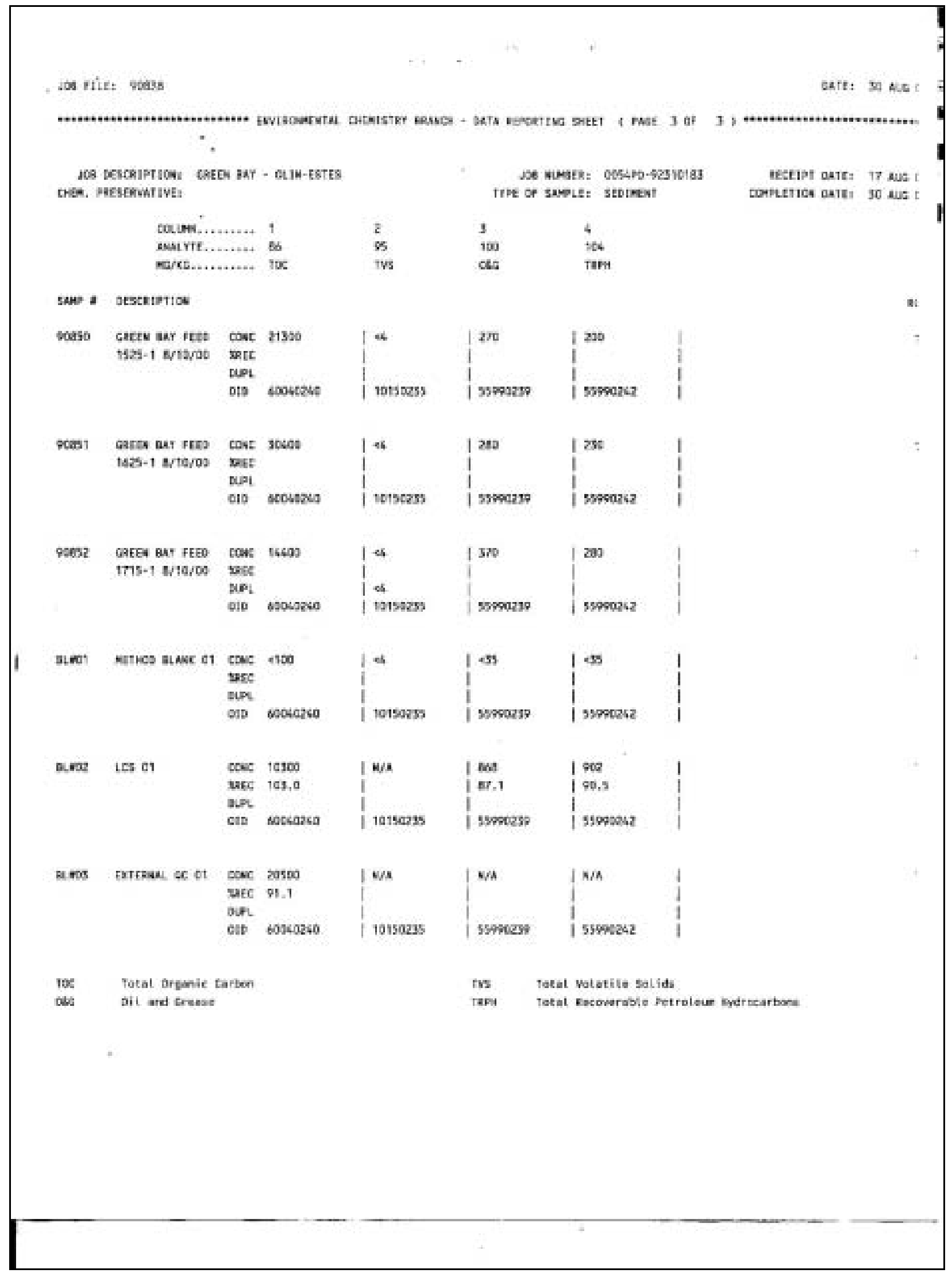




\section{INTERNAL QC DATA}

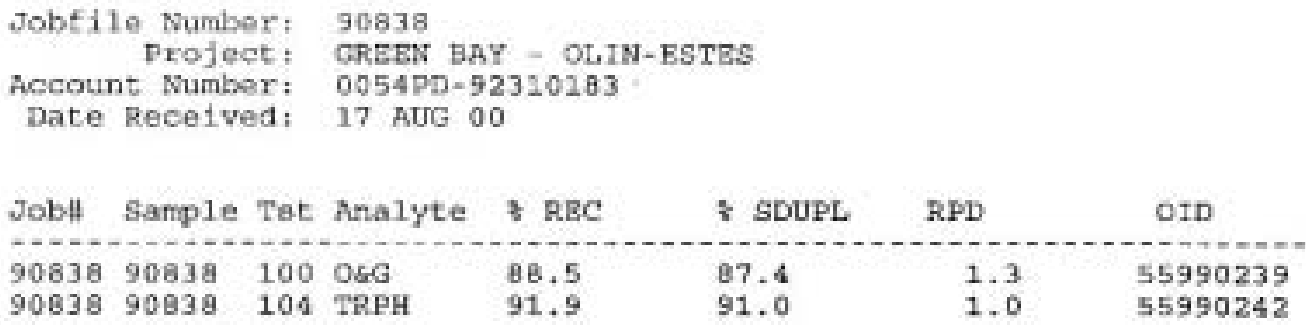




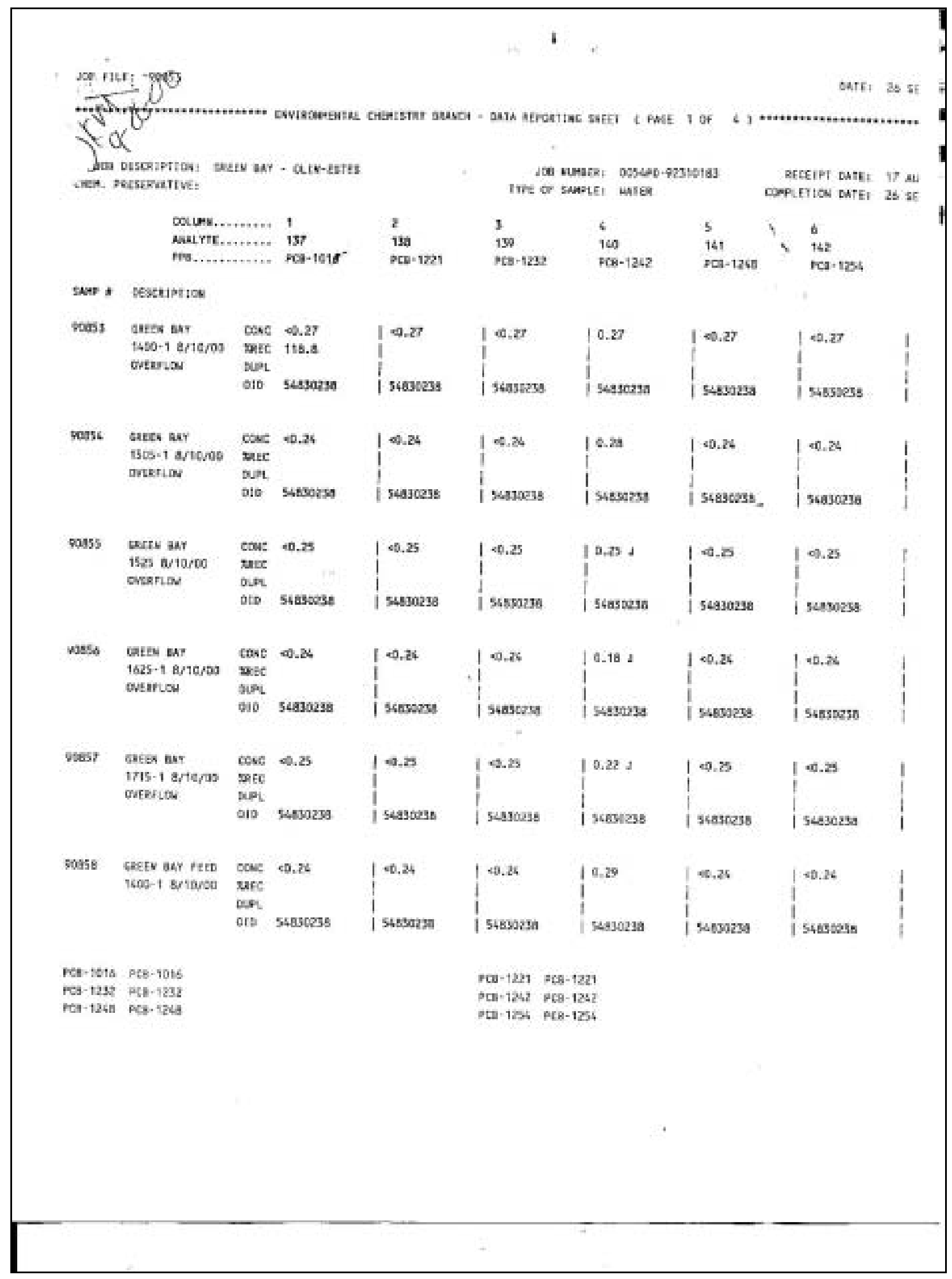




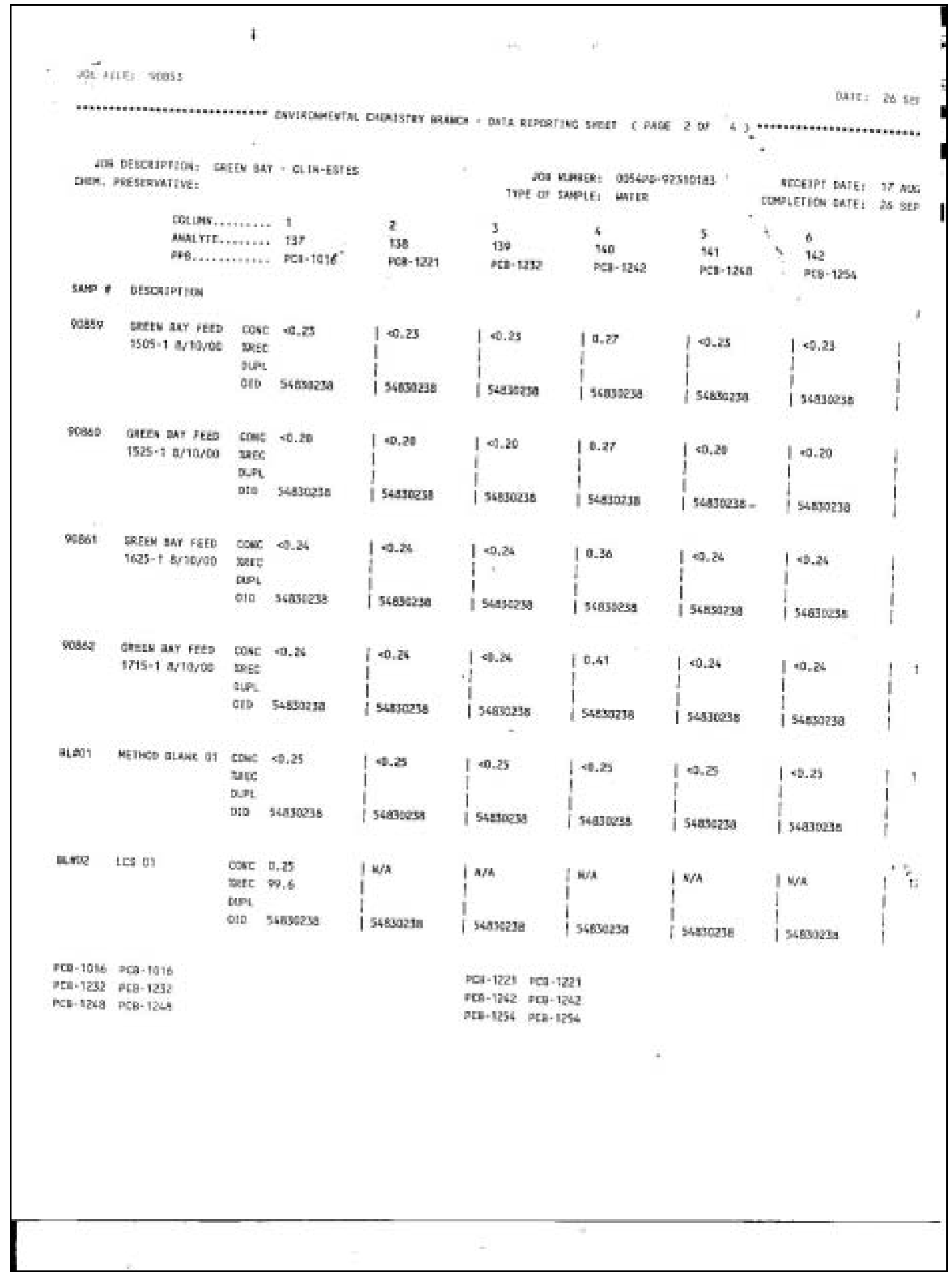


Jón Fiffi 90053

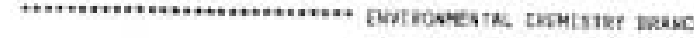

J03 bescriptrow! Gaech any - oula-tstis cren, mesterstrue:

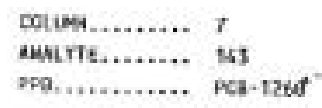

$+$

$$
\text { spa. }
$$

GWTA Rencettac seret

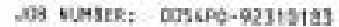
The of saver: wares

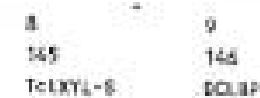

necrapt Rare: 17 aLA conterras part: is 20

save * otscaprios

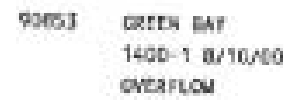

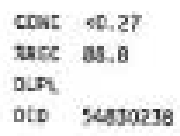

I 60,08

165.6

I

1 *asmes

| 4.6 .6

I tos.6

1

iscascoss

9oess totes axs

tont $=0.75$

overuces
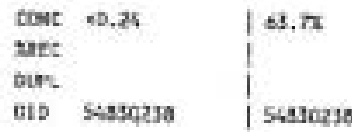

1 66. v5

54838028

$\checkmark$

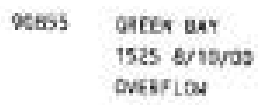

Oetros gafes uat

1525 surispas

DUEaritas
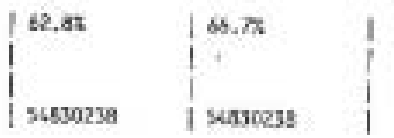

nows Gates nar

to2s: 1 areico

ovensou

cosc 40.26
wot
cuph
cib sc5sa2ss

$\left\{\begin{array}{l}70,62 \\ \text { stseansa }\end{array}\right.$

1 $70 . \mathrm{m}$

4

I

seanoese

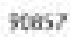

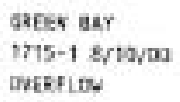

$$
\begin{aligned}
& \text { cove wo.zs } \\
& \text { wete } \\
& \text { wel } \\
& \text { ogo stescezs }
\end{aligned}
$$

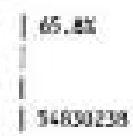

$\begin{cases}66.87 & \mid \\ 5050235 & 1\end{cases}$

Scess taEen aAT recs T6m-1 suspas

$$
\begin{aligned}
& \text { cave } 0.26 \\
& \text { wote } \\
& \text { fupt } \\
& \text { old 548sose }
\end{aligned}
$$
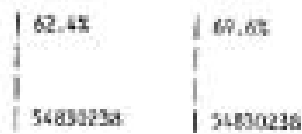

Fes-tate pc4-12ne

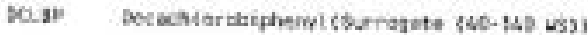

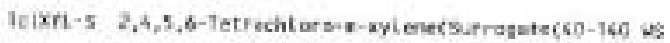




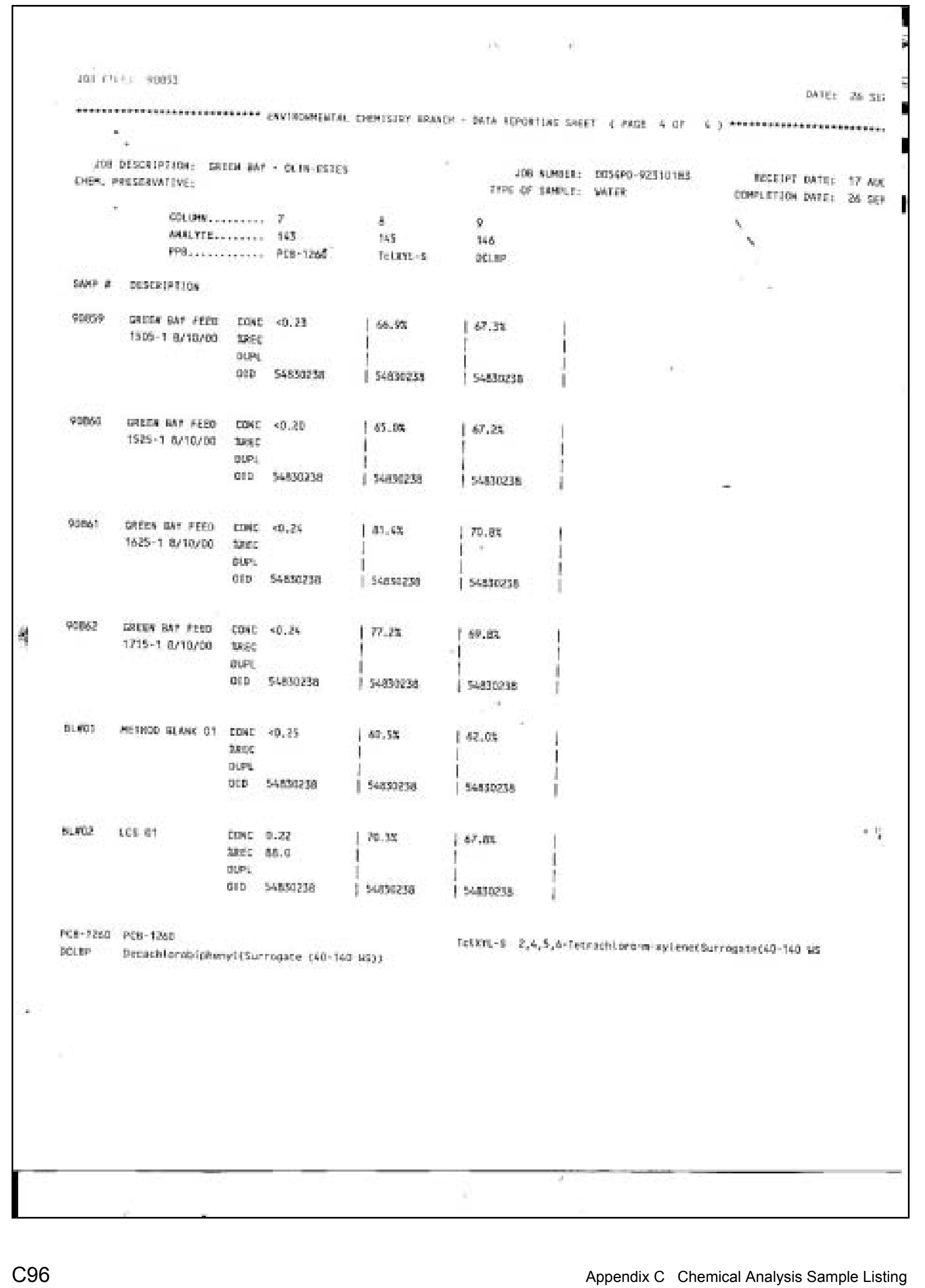




\section{INTERNAL QC DATA}

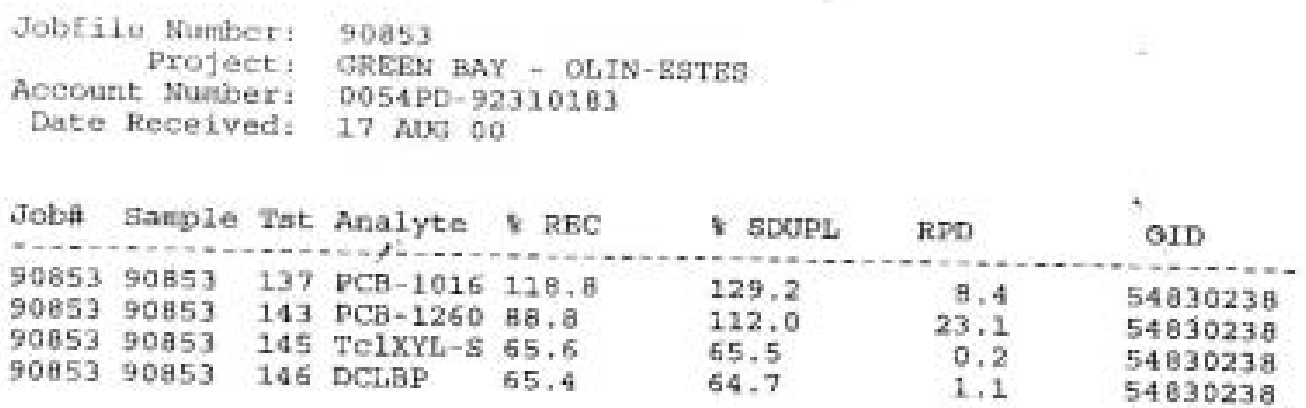




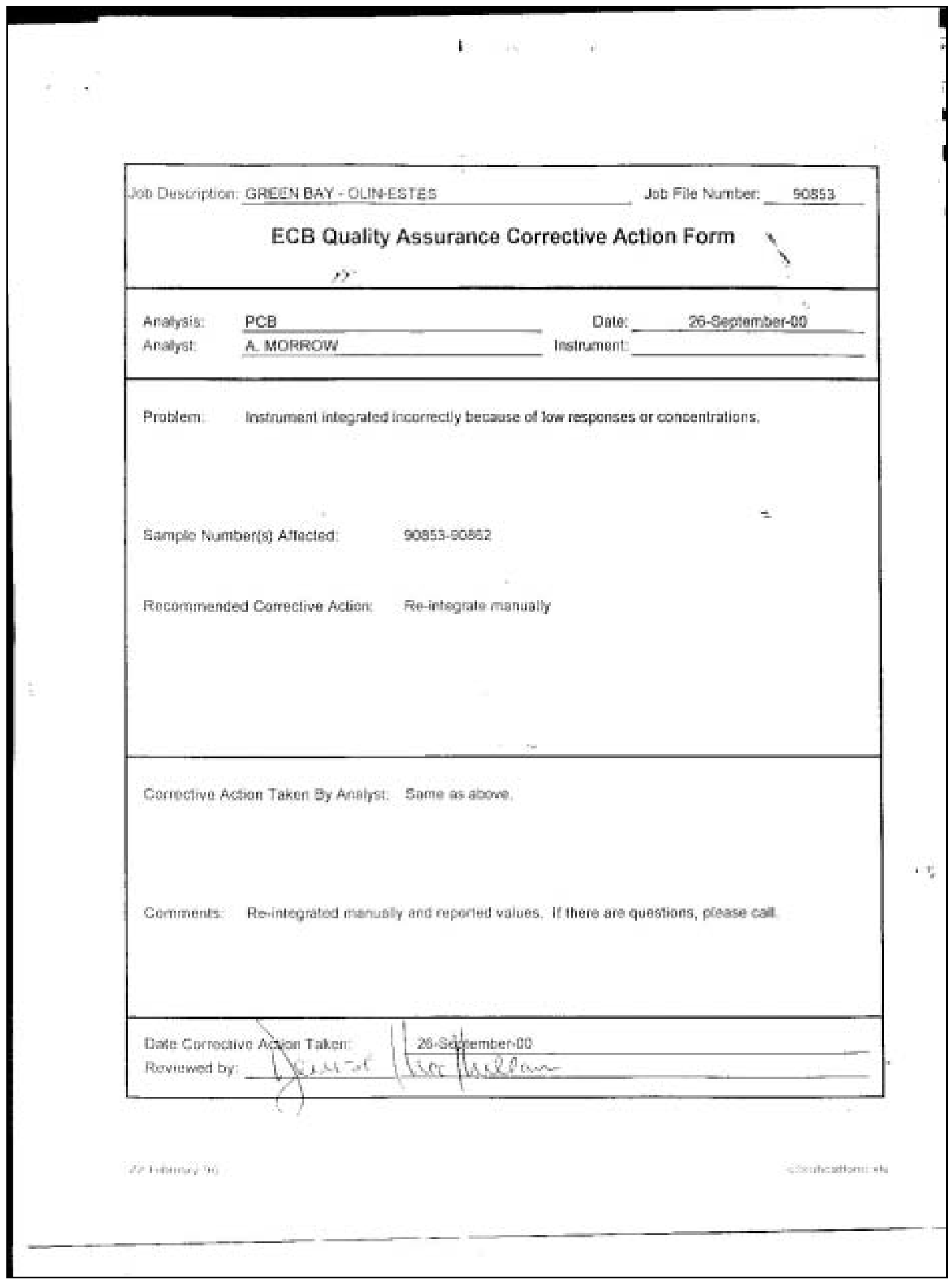




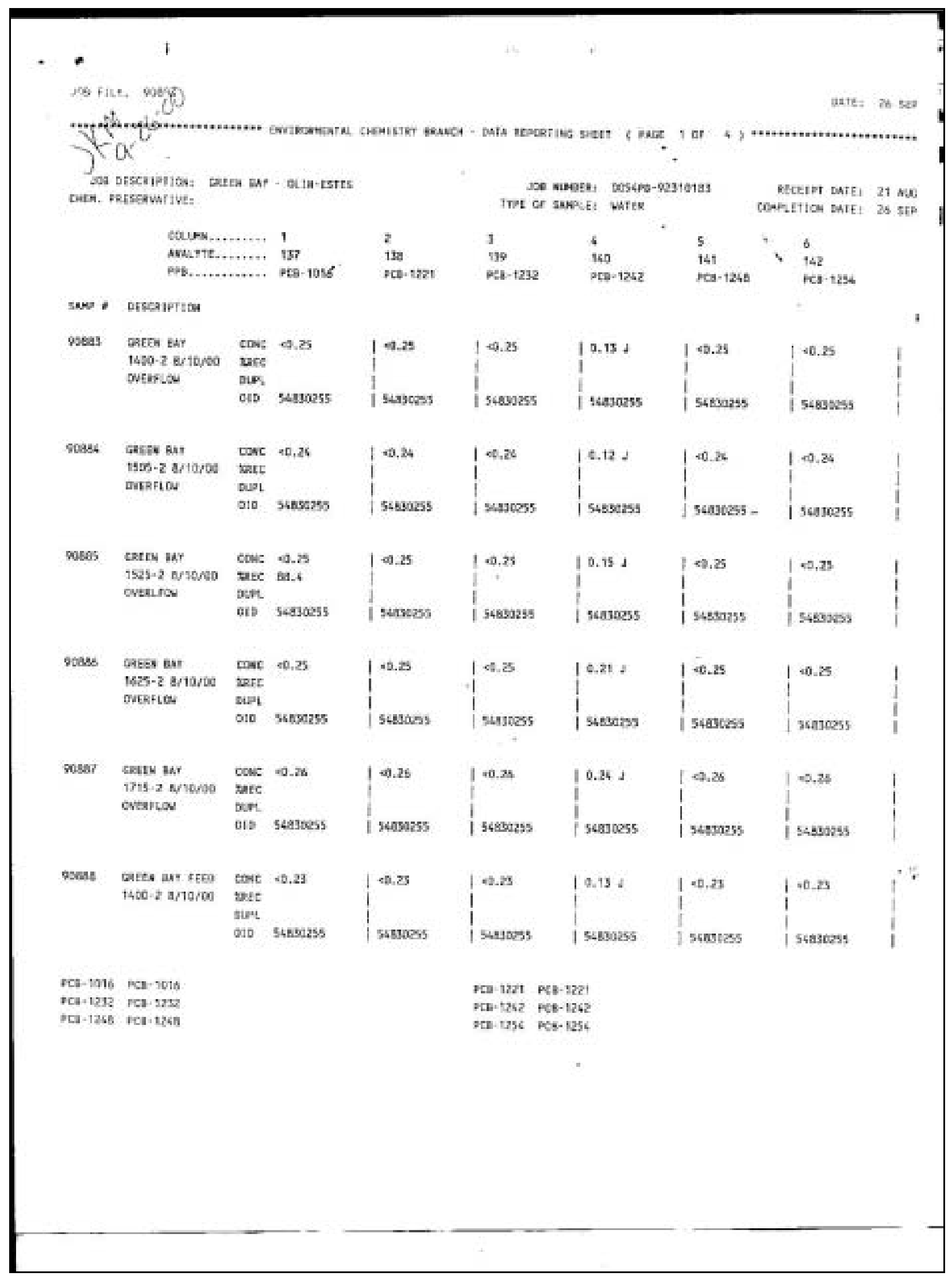


ins ilit: wass

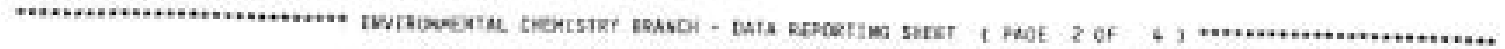
?.

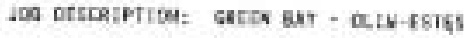
crea, pecsenative:

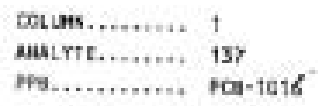

1 +0.26

i 54800255

Whot RETace alase th cove $\angle D, 25$

$$
\text { bas? }
$$$$
\text { ats: }
$$$$
\text { uts sumass }
$$
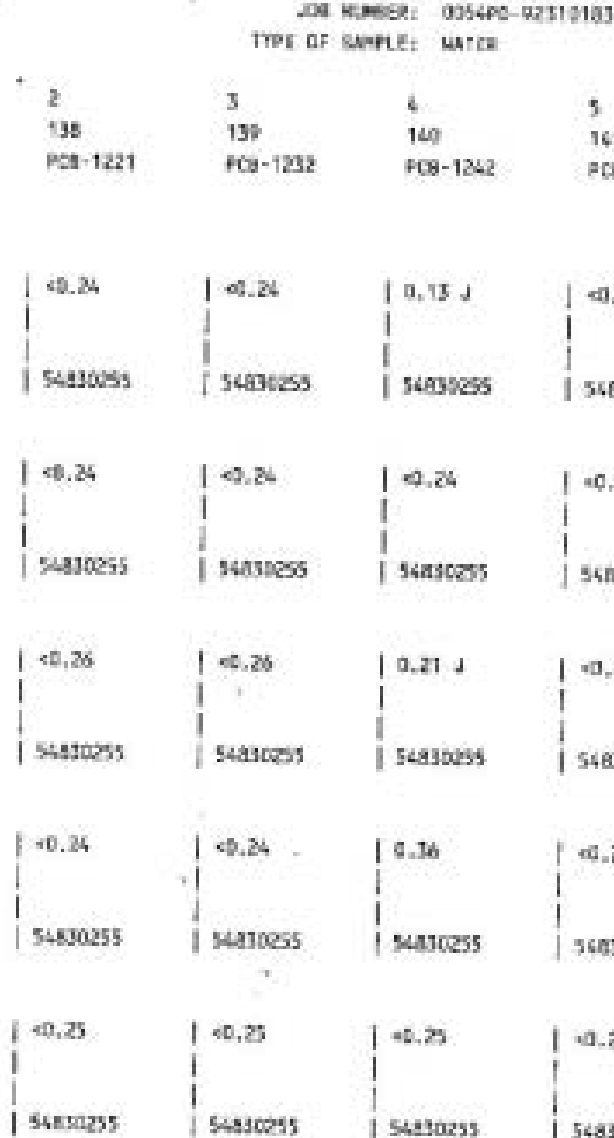

Eefiet daser 21 sug woterina marki as sen 2 195 pca-1221

3 139148 fCg-1232
$364 \div 8$

ac8-1248 PC:-1254
AtADe tes ot

\begin{tabular}{|c|c|c|}
\hline thas & 2,57 & $1 \mathrm{k} / \mathrm{A}$ \\
\hline twet & G5,a & $i$ \\
\hline oup! & & 1 \\
\hline OAD & 54090255 & I 56590255 \\
\hline
\end{tabular}

Fanters keaters

pal-1232 ra: 1212

han-1250 has-1268
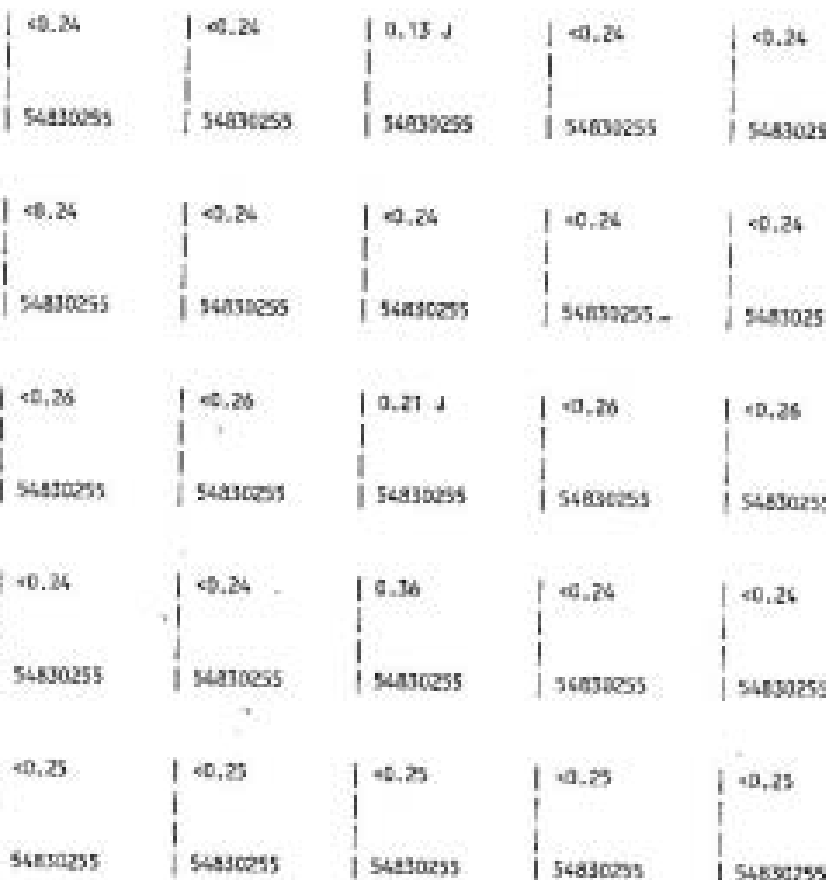

I s4astass
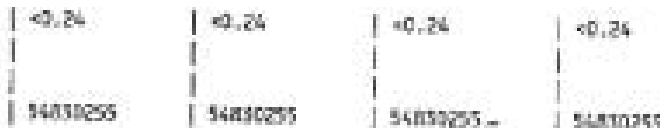

106.26

i
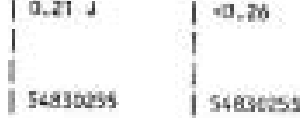

I $=0,25$

I

sisuozs:
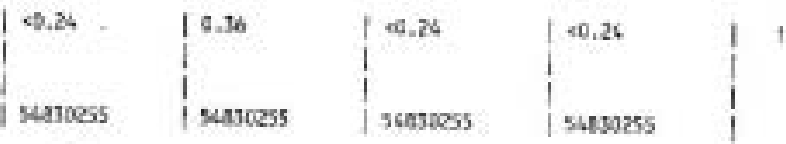

$1+0.25$

I
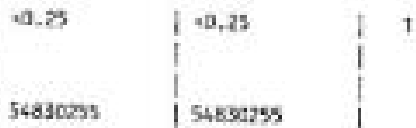

54azazss

1 548300ss

S4t5rits:
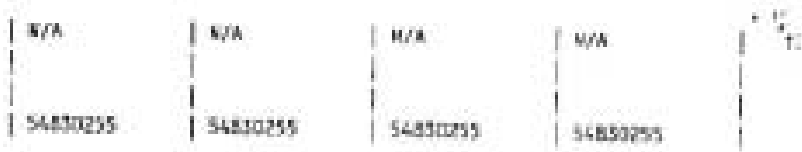

95: 1221 Fat-122

PCs-1252 $\mathrm{ras}-1262$

PCa-1256 ran-125t 


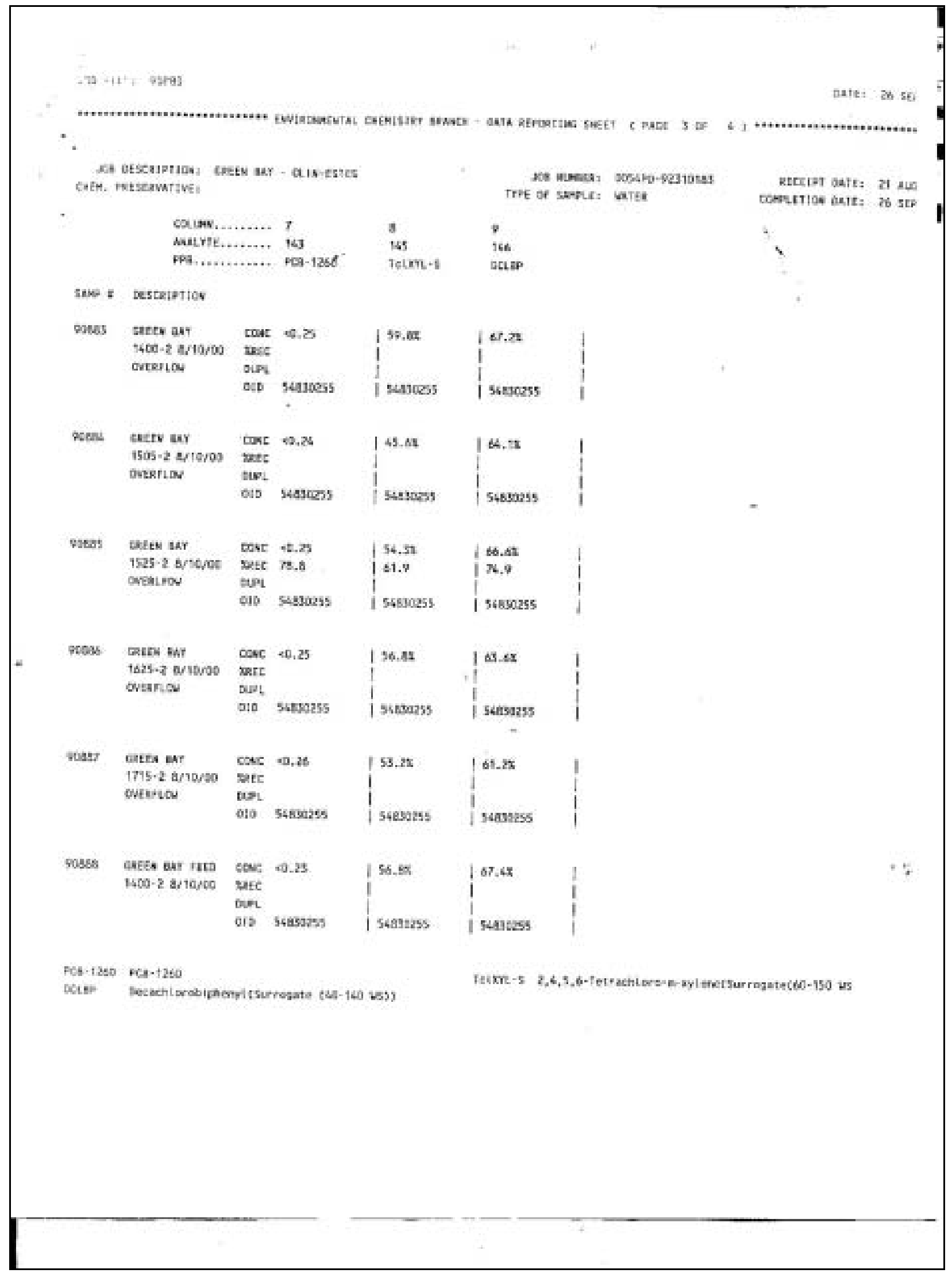




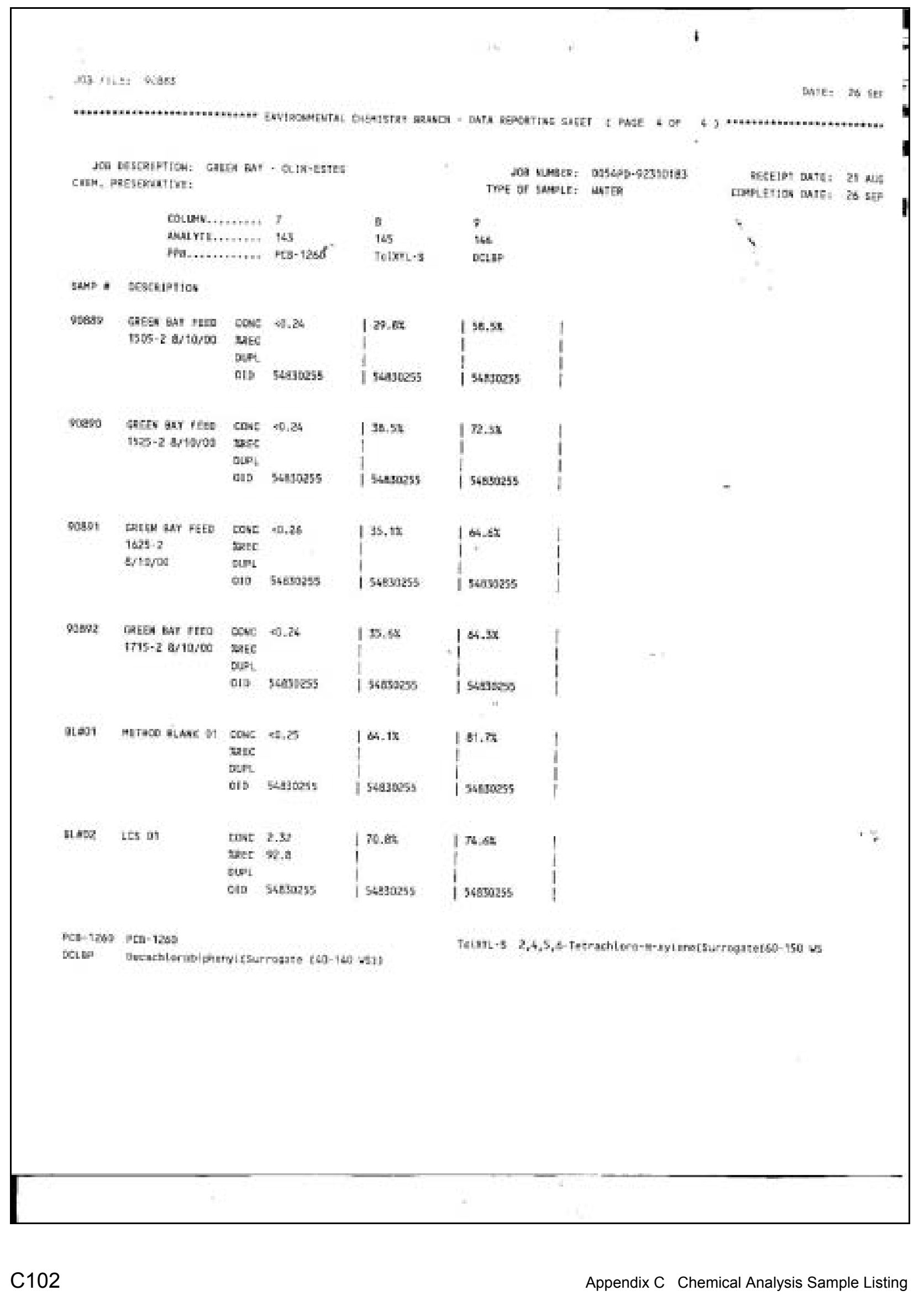




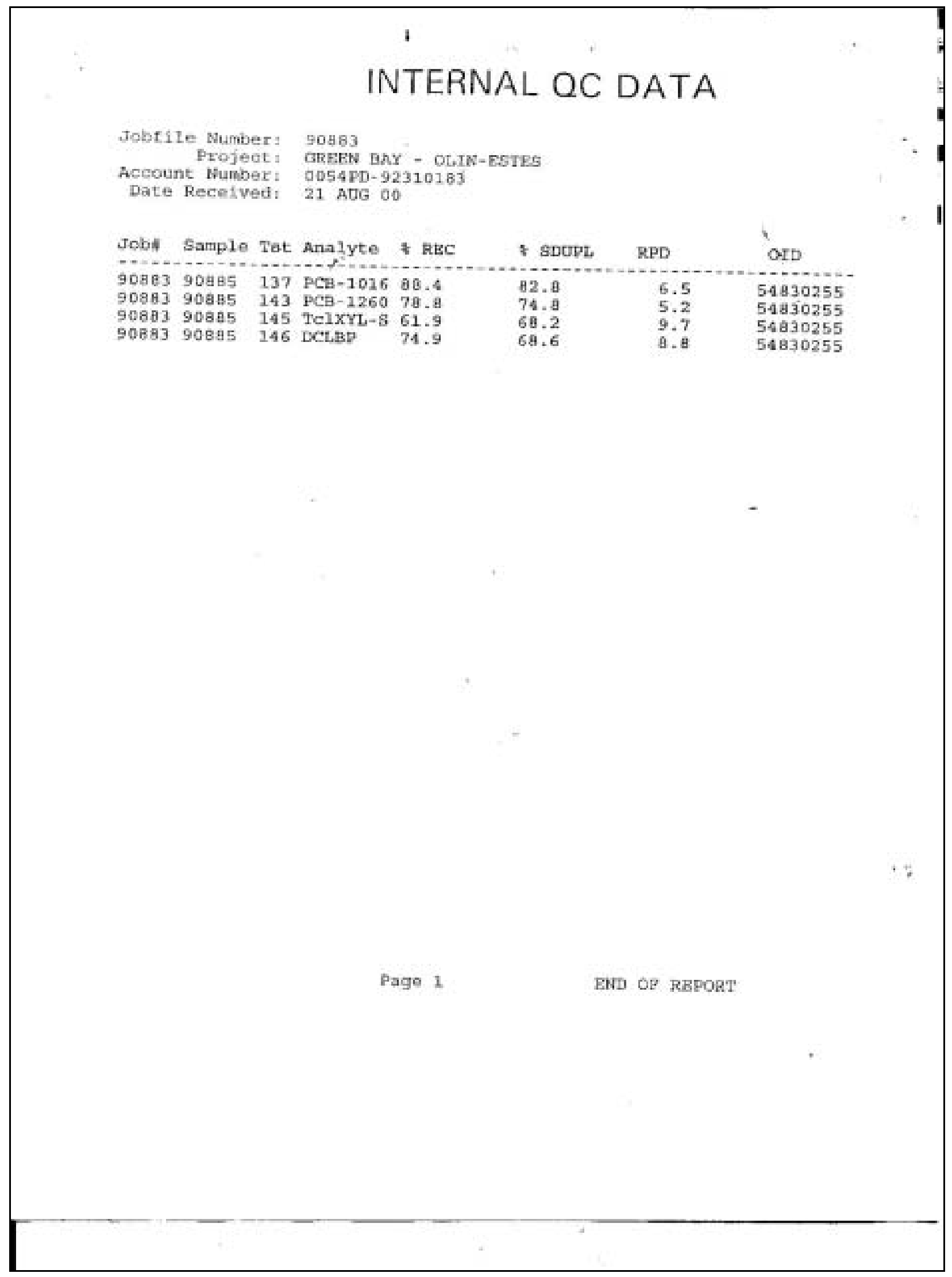




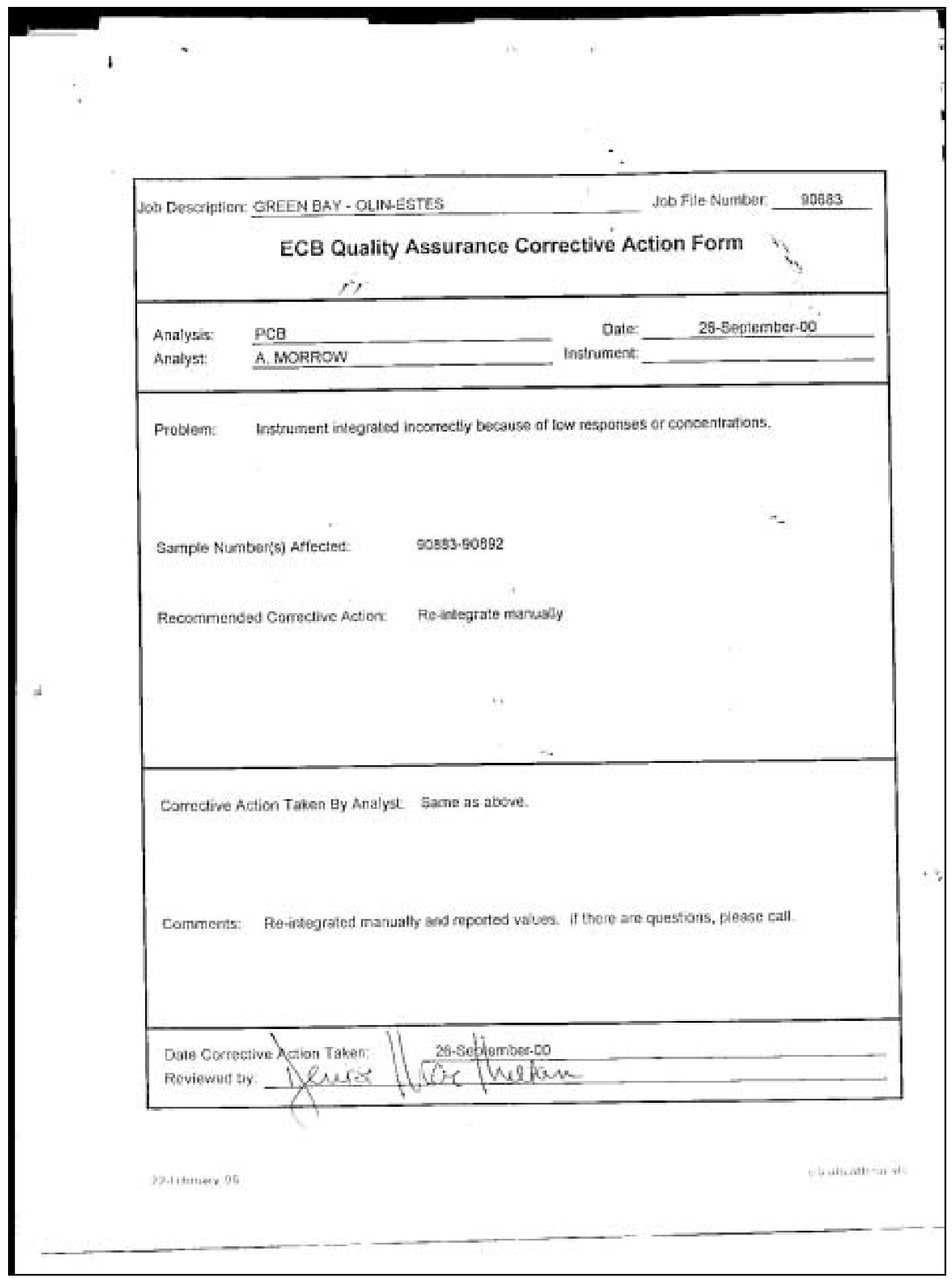




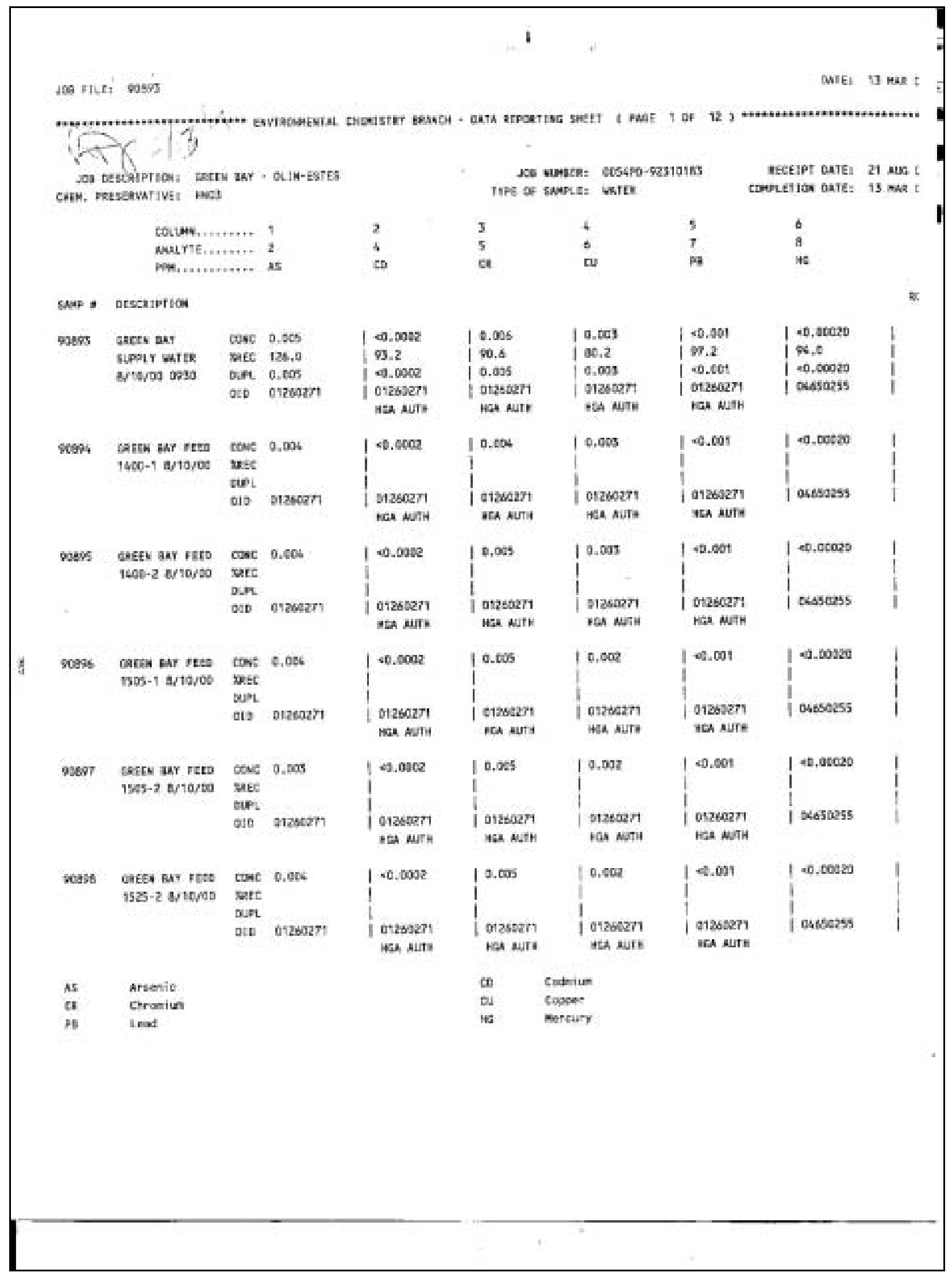




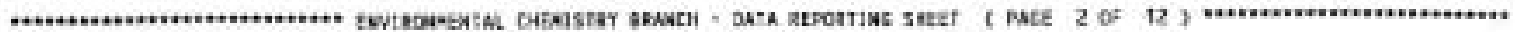

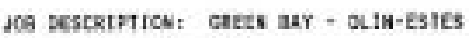

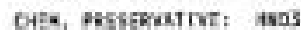

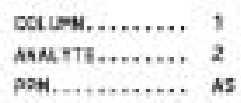

step $x$ sesctiplion

posw

CKEES BaY FEED
ISES-2 BNTDOOO

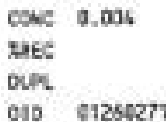

Q⿱艹 $1 \mathrm{bas}+1 \mathrm{e} / 10 / 00$

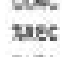

Dup:

cas Gasoen

\$opor

Gatry EAp rteg $1425-2$ B $10 / 00$

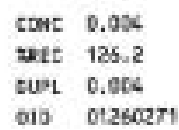

6002

GaEes BAT FEED $775=1$ arteros

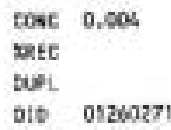

woses sarts bay $+\mathrm{E}: \mathrm{D}$ $17+5-2$ spisino

$$
\begin{aligned}
& \text { CosG } \\
& \text { wed } \\
& \text { DSAl }
\end{aligned}
$$$$
\text { eip 0120527 }
$$

9ocos catte har $1600+1 \mathrm{E} / 10 / 30$ cutairou

$$
\begin{aligned}
& \text { ccw: } 0.006 \\
& \text { tate } \\
& \text { nupl } \\
& \text { oud c12scent }
\end{aligned}
$$

aca wate: $\cos 400-923+6193$ TYPE OF SHAD: HATE

$\frac{2}{4}$

$\infty$

3
5
ca
-

AECETPT DAIEI 21 WLE COALLETIOA DAFE! 13 MaA

is

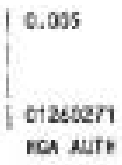

I 0.064
I ot2seart
Igt math

c.,204

Q

| c.tos

| 0ะ:24227t

was aytr

1 0.004

i

I

orizest

Fa NATN

| 012632?!

Ach Airn
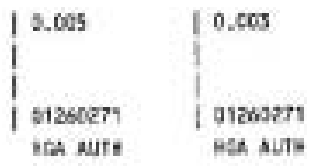

W5A A.TH
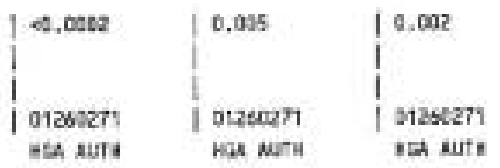

6,001

alase?

I5A aure

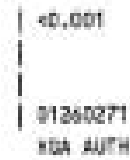

$\mid \begin{aligned} & 0.00060 \\ & \text { ectsecss }\end{aligned}$

| 40,001

a13s:2n

sa sury

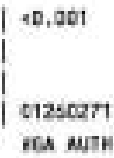

$\infty .00$ s

96.2

| 9.001

พด้ Aงกา
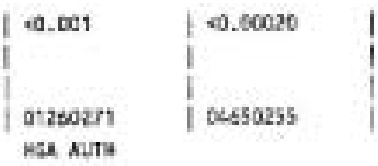

$40 . \cos 20$

! 0455025

(2) $\begin{array}{ll}\text { CD } & \text { Conduiur } \\ \text { id } & \text { Copser } \\ 10 & \text { noreury }\end{array}$ 
J6s FILEt goos

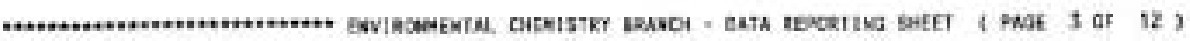

*.

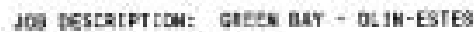

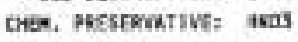

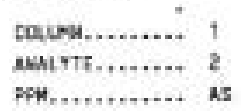

stap 4 Destolptice

tetes sar
12ab-2 $8 / 1000$
ontrstos

DC6C D.tos

GaEC

os.

ocb 0926927)

4

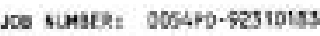

TPE of SAMPLE: WRIE!

$\begin{array}{lll}3 & 4 & 5 \\ 5 & 6 & 7 \\ 78 & \text { cu } & 78\end{array}$
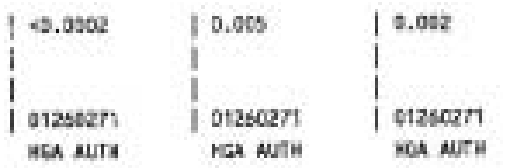

RICHIPI DMTEI 2I ALE CTPLIETIOA OAIEt $13 \mathrm{MAB}$
8

\begin{tabular}{ll|l} 
etac 0.005 & $a, 0 t e 2$
\end{tabular} 15a5.1 a/10rto tabe Diterto our. c10 9126727

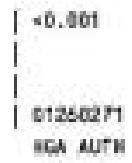

e.t.0020

1

ostsozss

0.205 $012 \sec 2$ 1 ica MTI WEA ALIH

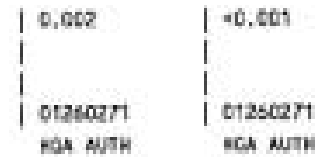

I.0.60020 oussorss

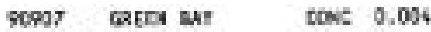
$1358-2$ a/tayos wac curRTLE

\begin{tabular}{|c|c|}
\hline 40.8097 & $0 . t 06$ \\
\hline & 1 \\
\hline & | \\
\hline $012 \operatorname{sez} \pi 1$ & | 0126e27s \\
\hline
\end{tabular}

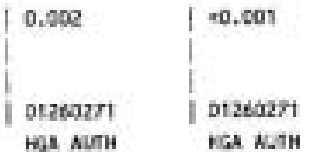

I $4 . \cos 20$

tow

Gaese aar toac 0,056

$7585-1$ siterou sete overnoy

Dupl

oto p126027

$\left\{\begin{array}{l}\infty 0, \cos 2 \\ 0 \sec 2 \pi\end{array}\right.$

1 a.006

I

via A.Tा

| t126127)

sea aufe

I $0, \mathrm{CR}$

I

I

c craser:

was aym

| *..60s

ot 2 เo27t ias NuTh

1 1 04550255

posed

cacen waY $1525.2 \mathrm{~B} / 10 \mathrm{pos}$

cose 0.605

ate 125,6

worl 0,505

015 0126027

| *1, 0028

10.005

03.2

at,otes

d c1asc2?t

I 55.4

I 9.005

w5A AUTH

| rasc271

| 0.002

as, 8

a. $\cos$

91262?

I *.6.

| 9 . 8

I ब. 601

1 ot2so27t

wa auts

99919 gerry ear ocke 0.t04

1625.1 a/10/50 vasc

cutafics

$\left\{\begin{array}{l}\text { as,asce } \\ \text { sizsoers }\end{array}\right.$
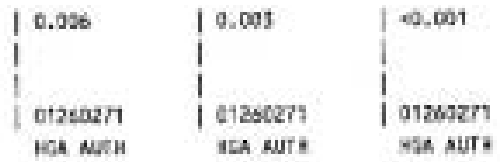

$\mid \begin{aligned} & \text { 4.060s } \\ & \text { ectestass }\end{aligned}$

$\begin{array}{ll}\text { as } & \text { arsente } \\ \text { to } & \text { Chroalin } \\ \text { to } & \text { Lead }\end{array}$
CD Cadsion

w Nerrury 


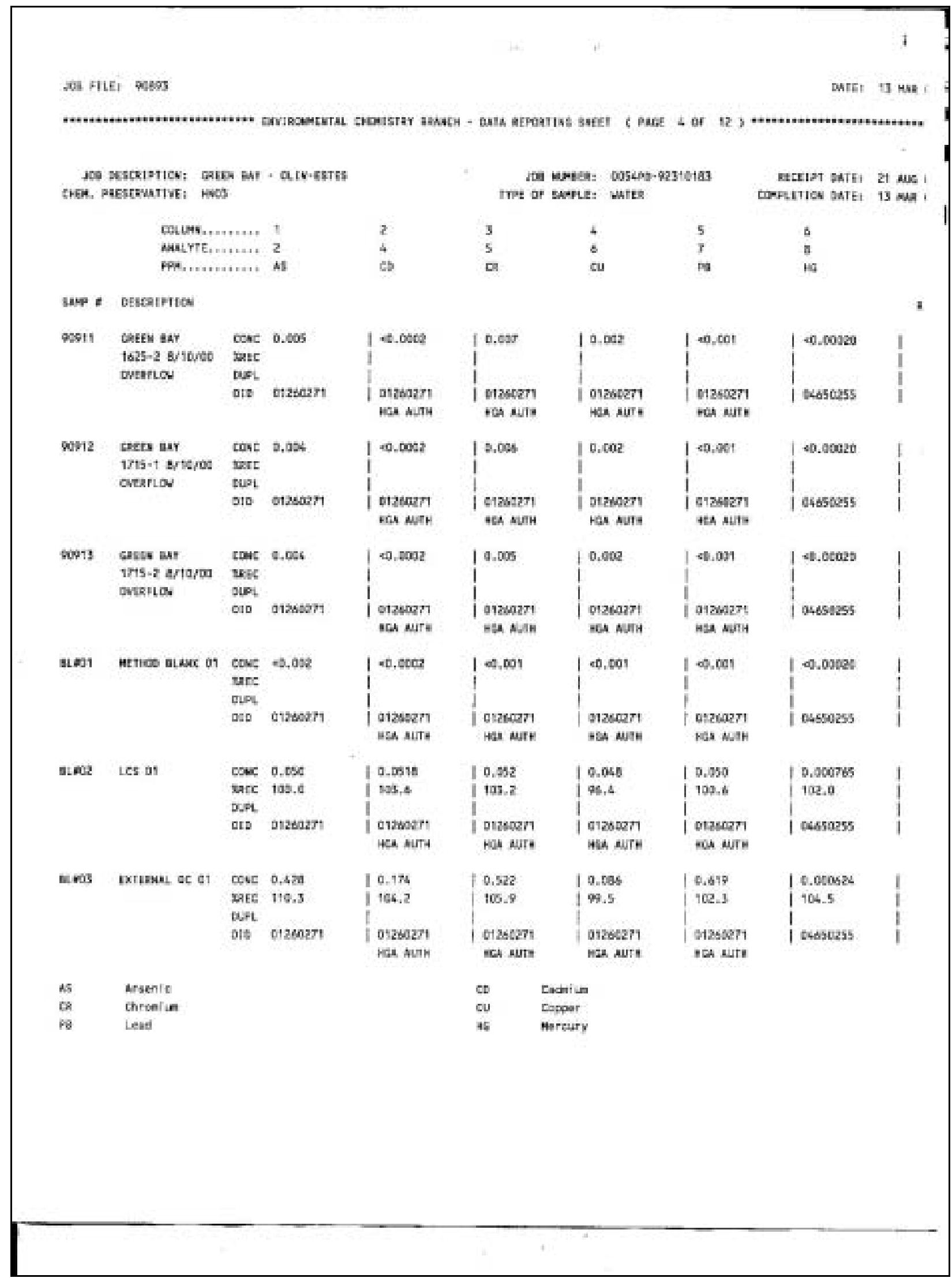




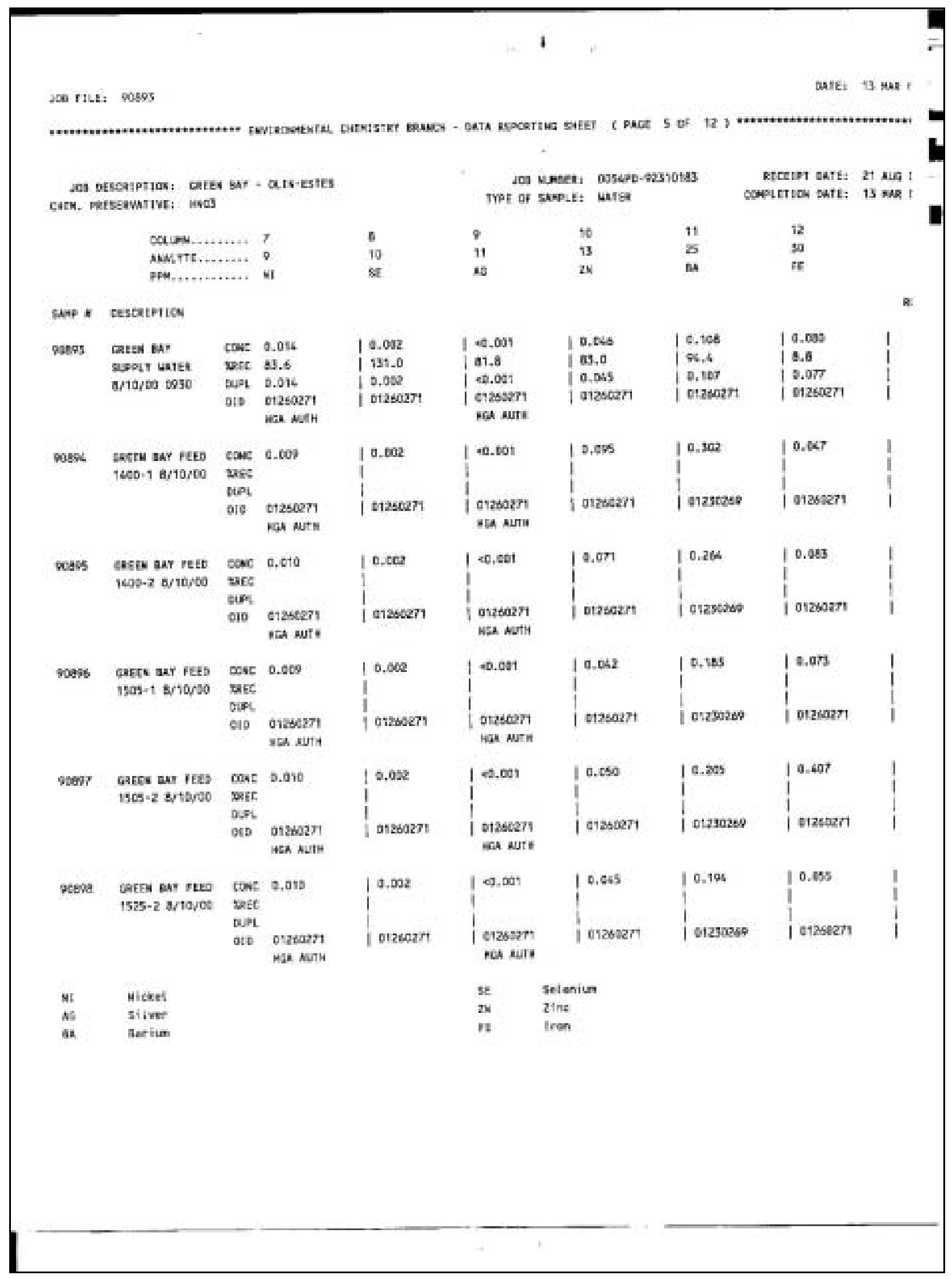




\section{i}

Jes rutin rans

arit: 13 The I

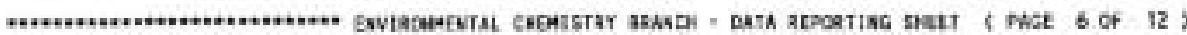

ye atscuprics: Gatek an - atih-Esfes CEFM. Patsinative: ital

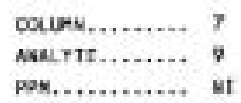

lawa $\approx$ Descaiption

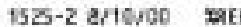

क्रा

eIb 0126925!

itม AบIH

sove GeEs BaY FEED COAC 0.60

1585-1 Bribreo viec

ain

oเD 0126127!

usa AUTH

gosol Gaets ay reto $1825-2$ sytorto

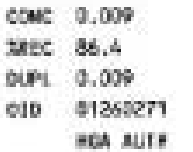

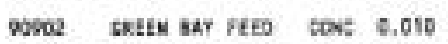

$17 \div 5-18 / 10 / 00$ wee

bupi.

o10 0126027

nos wif

gesos tokew sat fees towe 0.010

$1715 \cdot 2$ artoroe wetc

tWi

010 Dizen27

Was ALIT

9oves carcu DA:

1sco-1 artorob

DUER.FDN

$$
\text { wose } 0.009
$$

xate

Dual

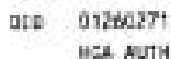

5
10
5

st

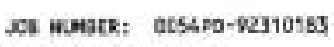
TYPE CF SUPLE: WeTr? aforip oate: 21 aug । COMPLETtom batt: is ma !

$$
\begin{aligned}
& 12 \\
& 36 \\
& 16
\end{aligned}
$$




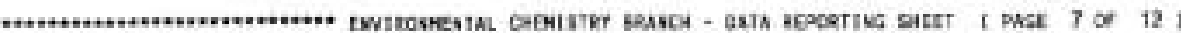

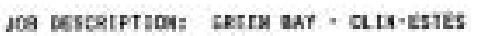
trot, heservatruer was

$$
\begin{aligned}
& \text { cos und........ ? } \\
& \text { Matre........ ? } \\
& \text { PPH ........... } \mathrm{M}
\end{aligned}
$$

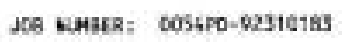
TrPE of SWALLI WHTE

a
ts
st

10
13

21
11

10

B
IDeript DATE: $21 \mathrm{hX}$ COAPLITIOS DATE: I3 MAA

\begin{tabular}{|c|c|}
\hline ckets aAY & $\cos$ \\
\hline $1400-2 \mathrm{~B} / 10 / 20$ & taec \\
\hline ovtarues & bur \\
\hline & QAD \\
\hline
\end{tabular}

12
gx
$r$

saty a testrintica

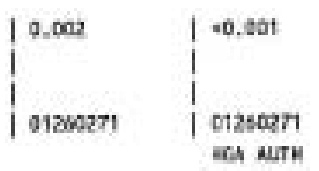

$\left\{\begin{array}{l}0.077 \\ 0125027\end{array}\right.$

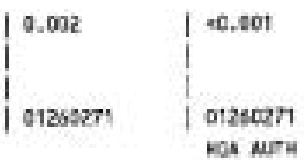

1 0.061

90900

ratrw sar
15as-1 B/10/to
ovtanou

6ows 0.025

vet

aun

otd 61250271

sca sutk

90907 ERTK EAP 15s5-2 a/1eroo
oviandoy

towe 0.000
watc
rupl
dio glasoent
ros neth

10.002

i I

$19 . \cos$

\begin{tabular}{|c|c|c|c|c|c|c|c|c|c|}
\hline \multirow[t]{5}{*}{ Procs } & CRTEW EAT & $\cos t$ & D.910 & 10,002 & | •... & 10.047 & I $0.1 \mathrm{ASS}$ & 10.054 & I \\
\hline & $1525-1,4 / 10 / 00$ & xate & & I & I & I & 1 & 1 & I \\
\hline & Drteriay & Dul & & I & I & 1 & I & 1 & I \\
\hline & & doro & $012502 \pi$ & | 0126027 & | orzsizm & | $0+260271$ & 102230269 & | 01260271 & I \\
\hline & & & nes AutH & & HWH A,TH & & & & \\
\hline \multirow[t]{5}{*}{90909} & catrs ant & cost & 0.600 & 10.022 & 1.0 .001 & 10.042 & 10.193 & 10.190 & I \\
\hline & $1325=2$ anta/00 & tatec & 68.5 & 129.2 & 10.2 & 181.2 & 196.4 & 198.6 & I \\
\hline & EITRTLQ & well & 0.000 & 0,952 & 100.001 & 10.043 & 0.193 & 10.155 & I \\
\hline & & ots & 0926027 & I oizenen & | aาrwa27 & | $012 \operatorname{sen} 27$ & I 0.250209 & | 9งам⿻上丨 & I \\
\hline & & & nea ลงกา & & W:a AumA & & & & \\
\hline \multirow[t]{5}{*}{ \$opso } & gaber ant & cose & 0.510 & 0.002 & I $<, 04$ & 10,029 & 10.121 & | 0.005 & I \\
\hline & s8-1 wtopas & xatc & & 1 & 1 & 1 & & I & I \\
\hline & DNERFLN & DST & & I & I & I & & 1 & I \\
\hline & & otP & onzta2s! & | 0s26027 & | 9126127) & | cาองอ2] & | o1zsasso & | a12sa27t & i \\
\hline & & & W5a sut? & & ves auth & & & & \\
\hline n & siekel & & & & st & Setevilun & & & \\
\hline NE & sitver & & & & $z$ & tite & & & \\
\hline EA & Batiun & & & & tr & 1 ren & & & \\
\hline
\end{tabular}

i t

tot26027 
480 Fric; vasos

Date: it wae t.

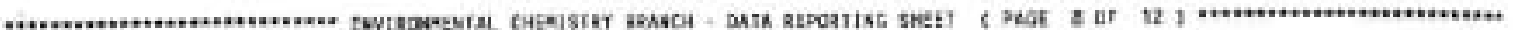
.

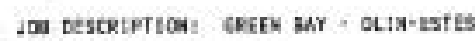

dot wirutE: 0354PD-92510tas

Dit*, patserafives net

$$
\begin{aligned}
& \text { CotiMs,........ } 7 \\
& \text { auarie......... \$ } \\
& \text { nites, }
\end{aligned}
$$

a

st

TrEe of SUpLE: GaTER

ettet:T tats: 21 new t COAPITICN CATEF 13 mas :

$\begin{array}{lll}9 & 15 & 11 \\ 11 & 13 & 25 \\ 10 & 24 & 34\end{array}$

\begin{tabular}{|c|c|c|}
\hline CREEA BAY & $\cos$ & 0.010 \\
\hline $1625-2$ a/10/60 & wetc & \\
\hline CUEFION & Duri & \\
\hline & O19 & $\begin{array}{l}61250271 \\
\text { res Nuri }\end{array}$ \\
\hline
\end{tabular}

12
35
12

SWP D DESRIPTID

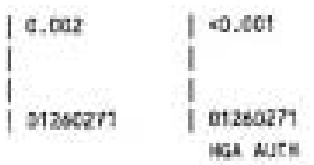

10,010

I

1. 012625

11

25

909

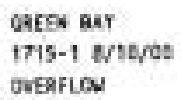

cont $\$ .010$

watc

\begin{tabular}{|c|c|}
\hline 8,032 & | $1 . .601$ \\
\hline & i \\
\hline & I \\
\hline 012sean & $\begin{array}{l}\text { a } 200271 \\
\text { asa Nuth }\end{array}$ \\
\hline
\end{tabular}

DurL

ots 0126027

$10 ., 522$

I

10

BCA AOTM

$+6,031$

5ov13 theEk 8AY $17 \div 5-2$ a/10/20

ocsc D. הo?

owsaftce

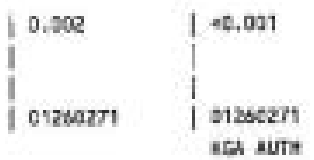

$\left\{\begin{array}{l}0.019 \\ 01260271\end{array}\right.$

vare

uxt.

atD et26027!

ats with

Bufo! NeTHOS BLAK of cove 4.091

นe:

$\tan$

ग10 A126027)

$1<2,002$

1

| sizosz

I *0.06t

otzecti
igh nutk

| 59,010

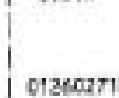

10.923

t+2302e?

01260071

| 0.134

i

aมรges

10.020

I

0434027

i

aLaje Les at

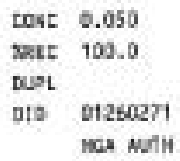

\begin{tabular}{|c|c|c|}
\hline \multirow[t]{4}{*}{ ExTERaL ac 61} & ocse & 2.54 \\
\hline & yet: & 102.0 \\
\hline & $0: \mathrm{pt}$ & \\
\hline & QsD & $\begin{array}{l}\text { asroazs? } \\
\text { ysa sury }\end{array}$ \\
\hline
\end{tabular}

10.051

101.0

orzene?

| 0.,550

I tos.6

cons

$\left\{\begin{array}{l}1,53 \\ 103.6 \\ 0125025\end{array}\right.$

1 0.526

| 702.5

i

\begin{tabular}{|c|c|}
\hline$=0.001$ & 50,920 \\
\hline & \\
\hline & \\
\hline $0 t 230259$ & c12ston \\
\hline
\end{tabular}

(

เอA जแT

\subsection{0 \\ 199.2 \\ 140}

I 65.8

1

wi wiekni

M silver

a. Bariun.

$\begin{array}{ll}\text { SE } & \text { Seveniun } \\ z y & \text { Iine } \\ t E & \text { Iron }\end{array}$




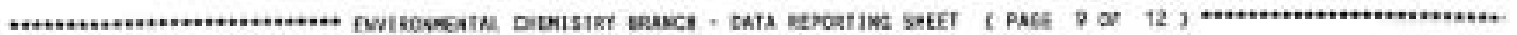

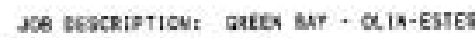

tre4. PaEsENatTIE: inos

$$
\begin{aligned}
& \text { CDIUR,......... } 1 \\
& \text { A5AL+TE ........ } 31 \\
& \text { DPM }
\end{aligned}
$$

say a testriptica

wass

chen ant
supher wite

srteros 0 so

$\cos n .6$

WEE 96,4

ber. 76.1

ole v12300so

13.03

| 56.2

1 3,05

I c12300es

poess

CRERN Dar FEEE

14t0-1 a/10,00

cosc $\pi$.

BaEc

6sil.

OCB Dizazes

1.40

1

0t2302s

goos gared war reag $1600=28 / t / 0 d$

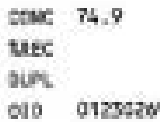

1,60

I

I

| a123azs

I

05260271
Jou knseat cosspo-pestoras TYp1 of sartet vates

ts

53
we stctipt DAtE: 25 ane conpietios DAtE: 13 Has pogst cazes uar fees cows $\pi .1$ | 1 .

1505-1 Briaros wat

DUD

o19 $6123005 \%$

i

01230258 | 0126227

posat tretw aAT fete cose 76,2

1SeS-2 B/10/:0 DeEC

6IV Dizsas:

\begin{tabular}{|l|l|}
1.82 & 0.003 \\
$\mid 0+230250$ & |
\end{tabular}

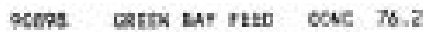

1525-2 a/torto

atc

our

oro 01230269

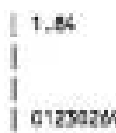

$\mid \begin{aligned} & 0.002 \\ & |0 \operatorname{los}|\end{aligned}$

NG Noyresiue

* Nolytaderna

W Rivitonese 
NoA FHE: 96ís

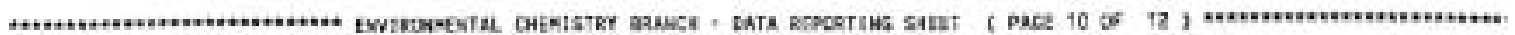

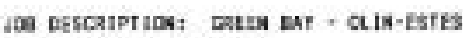
OAEk, Heserwattur: was

$$
\begin{aligned}
& \text { colias, ........ th } \\
& \text { Warre....... } 3 \\
& \text { pow............. wE }
\end{aligned}
$$

stw $x$ bescaiprios

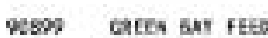
$1525-2$ anterod

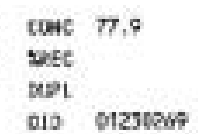

IECEIPT DATEL 21 aUS I COMPLETIOS OSIEL 13 XNR ।

$\begin{array}{ll}16 & 15 \\ 32 & 33 \\ 45 & 165\end{array}$

\begin{tabular}{l|l|}
1.97 & 0.002 \\
c12300es & $\mid$
\end{tabular}

$\mid$\begin{tabular}{l|}
0.003 \\
stastern
\end{tabular}

\begin{tabular}{l|l|}
0.202 \\
1 \\
0
\end{tabular}

posos cotes bar reed tows 78.0 $1715-2$ a/10/03 zet

ote c1250ewe

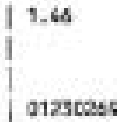

I

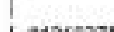

Focs Grot aA

bove 78.6

16to- 1 sicjos DVERLFO

wet:

Dur

ore Dt2308se

$\left\{\begin{array}{l}1,72 \\ 0123026\end{array}\right.$

$\left\{_{10.005}^{0.05027}\right.$

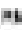

Menasinere

* Nognesilua

nolvodersen 


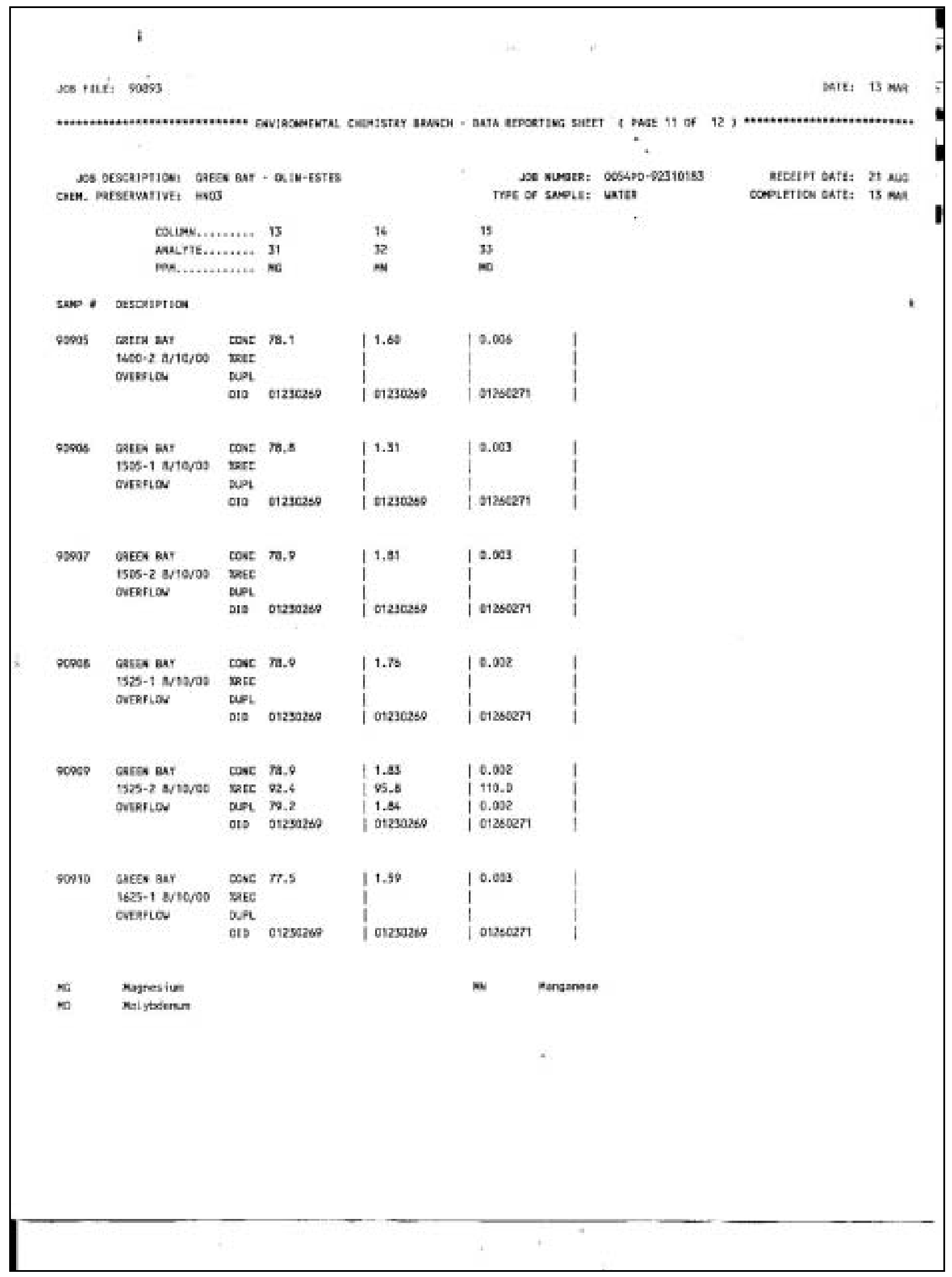




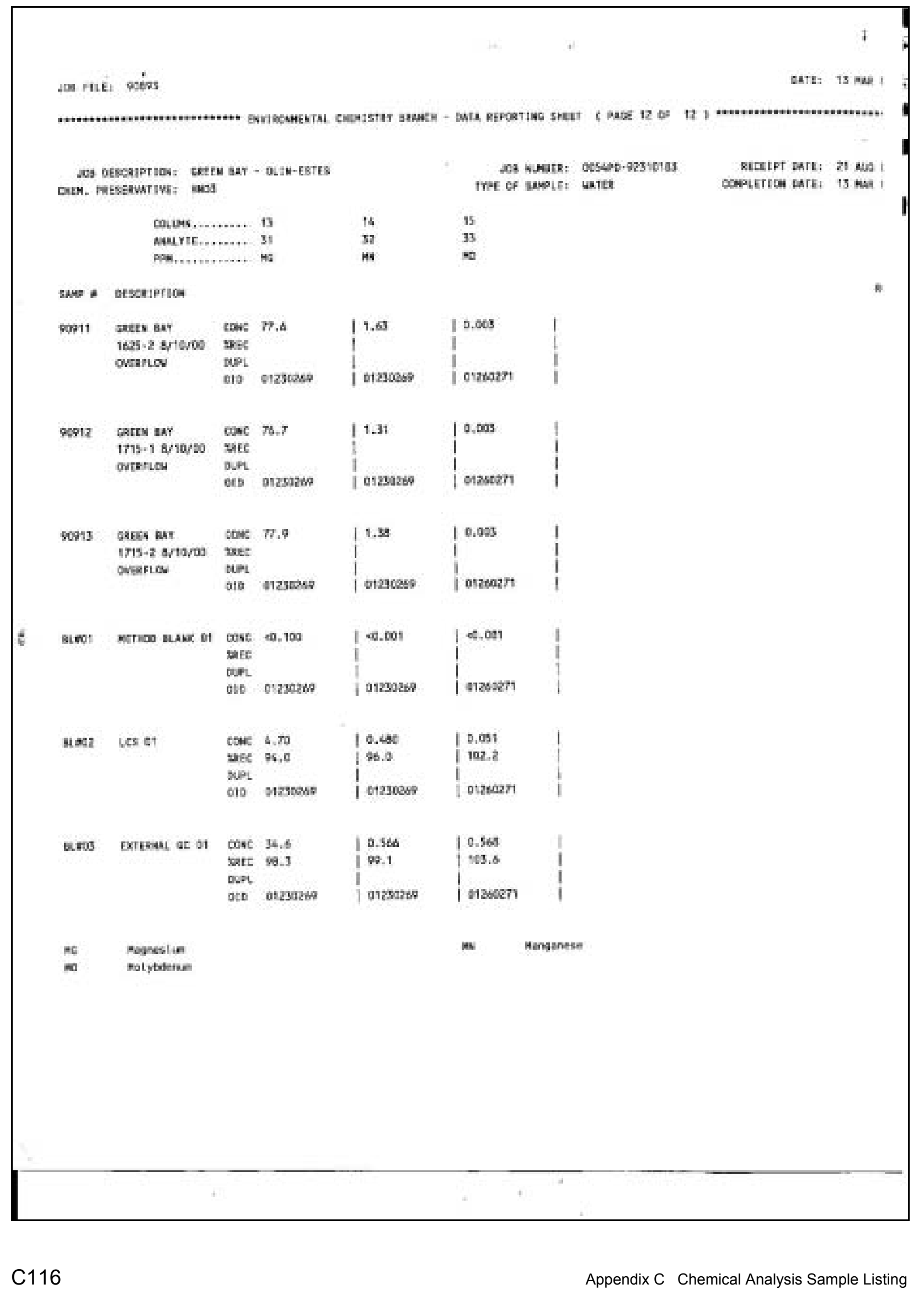




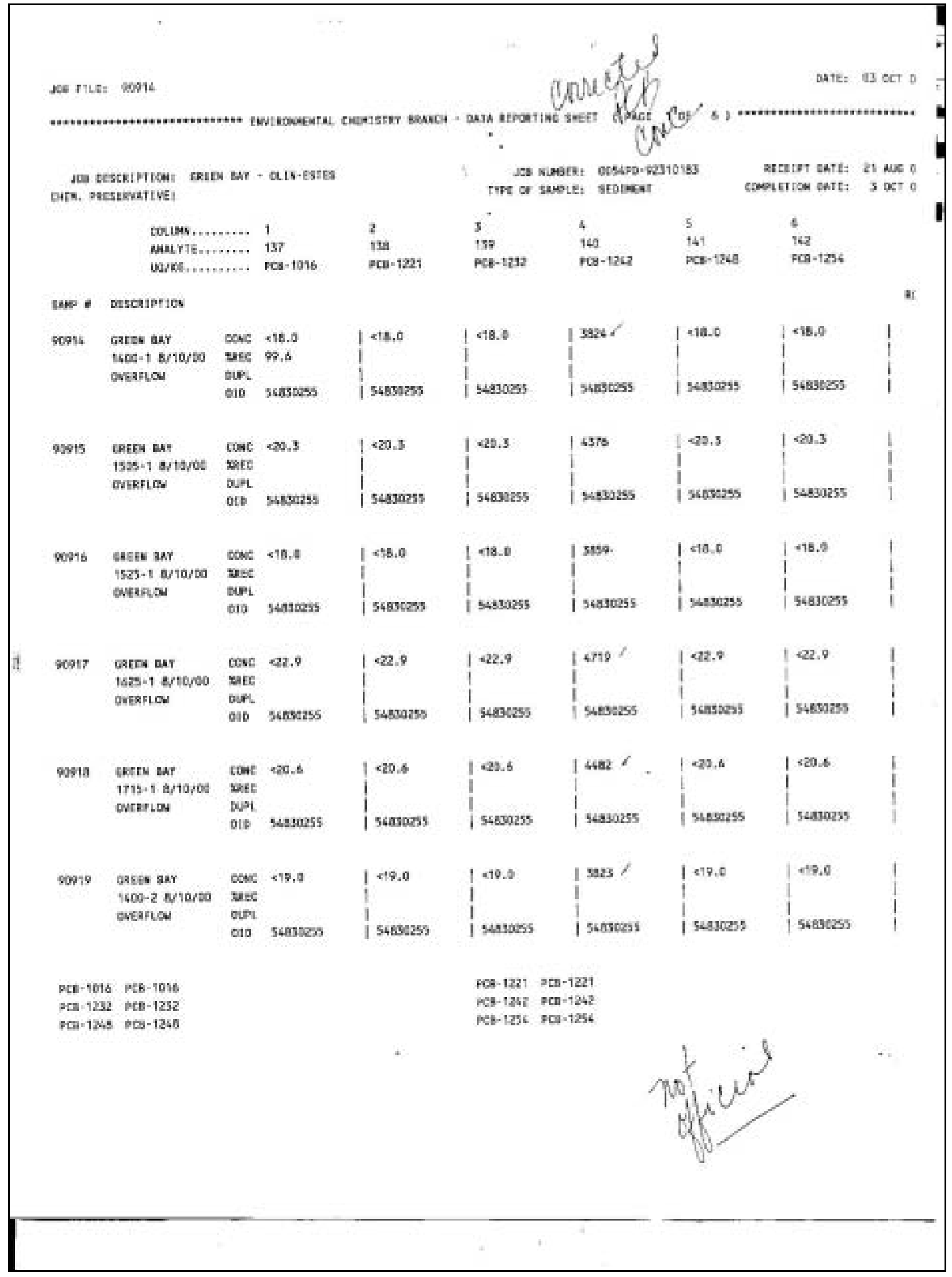




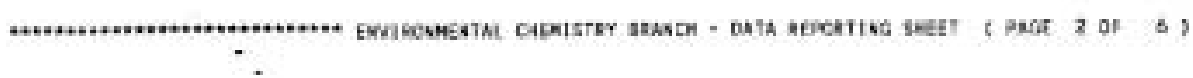

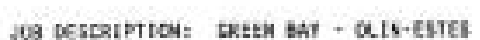
CAEN, ARELERTRTVE:

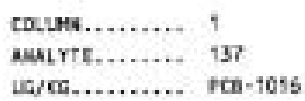

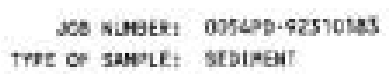

Tre of sample: stbi*ear 130

ACE-1221

3

130

4

so

pts-1242

도 1232
RErE!n DATE: 21 ANO : COPIETICN aATE: 3 OKT :

162

act-12s4

san \& eescaiptica

Fo2s DREeA RAT 1505-2 8/10/00 dotkfLC

\begin{tabular}{|c|c|}
\hline cone & 020.6 \\
\hline yec & \\
\hline MPL & \\
\hline & $241 \times 12$ \\
\hline
\end{tabular}

$1<20.4$

I

i

161 1269

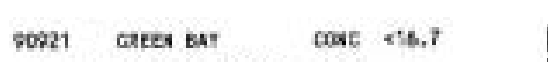

$1526 \cdot 2$ 8/10/00 Whe

CIERTLO DNPL

ord stroavs

$\left\{\begin{array}{l}\text {.16.7 } \\ \text { 5483tess }\end{array}\right.$

$1 \propto 0,6$

I

54kotass | susuoess

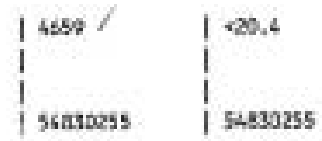

1420,4

I s6asoess

54832255

6osn Gatts aar

isas-2 $\leq p+0$ toto

casc 421.5

ovberioy

torec

eip striczss

1 20.5

i

ets

I
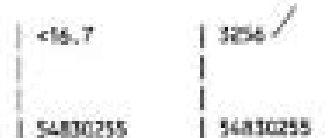

1 45.7

S45925s

$\mid 46.7$

15400255

I gatazss

t.

suguness

2

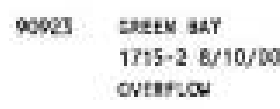

\begin{tabular}{|c|c|}
\hline $\cos :$ & 216.1 \\
\hline xe: & \\
\hline etr. & \\
\hline Q10 & 56130255 \\
\hline
\end{tabular}

$\left\{\begin{array}{l}416.1 \\ 54600255\end{array}\right.$
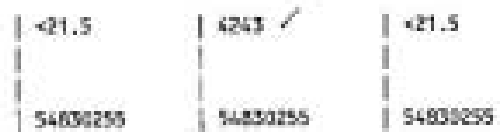

$1.2 \% .5$

54030255
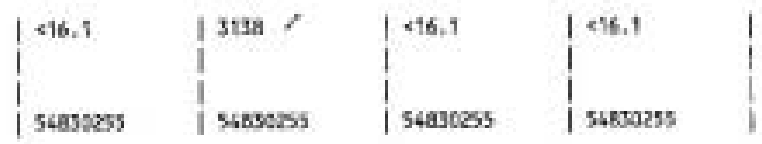

9tost

CREEX SAT FEEO
$1400-1$ B/10/00

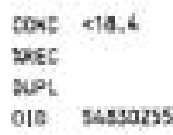

$\left\{\begin{array}{l}418,4 \\ 56855255\end{array}\right.$

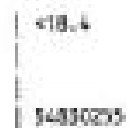

$\left\{\begin{array}{l}3640 \\ \text { s sostoes5 }\end{array}\right.$
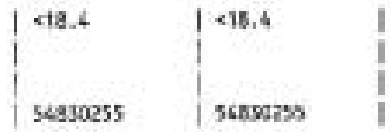

Gonzs Gatod ex, fett
$1505-2$ artorob

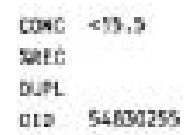

$\left\{\begin{array}{l}\text { I. } 15.5 \\ \text { sessocess }\end{array}\right.$
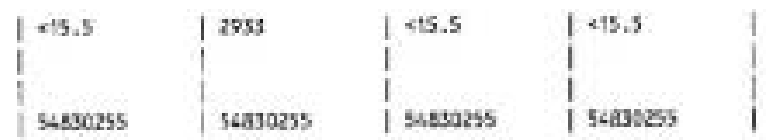

pca-10us poq-1016

PC3-1252 PGS-1252

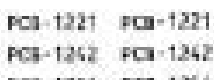

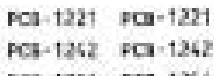

PCs-1256 PCa.1256

Ac4-1248 fol-1260

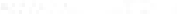

34

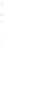




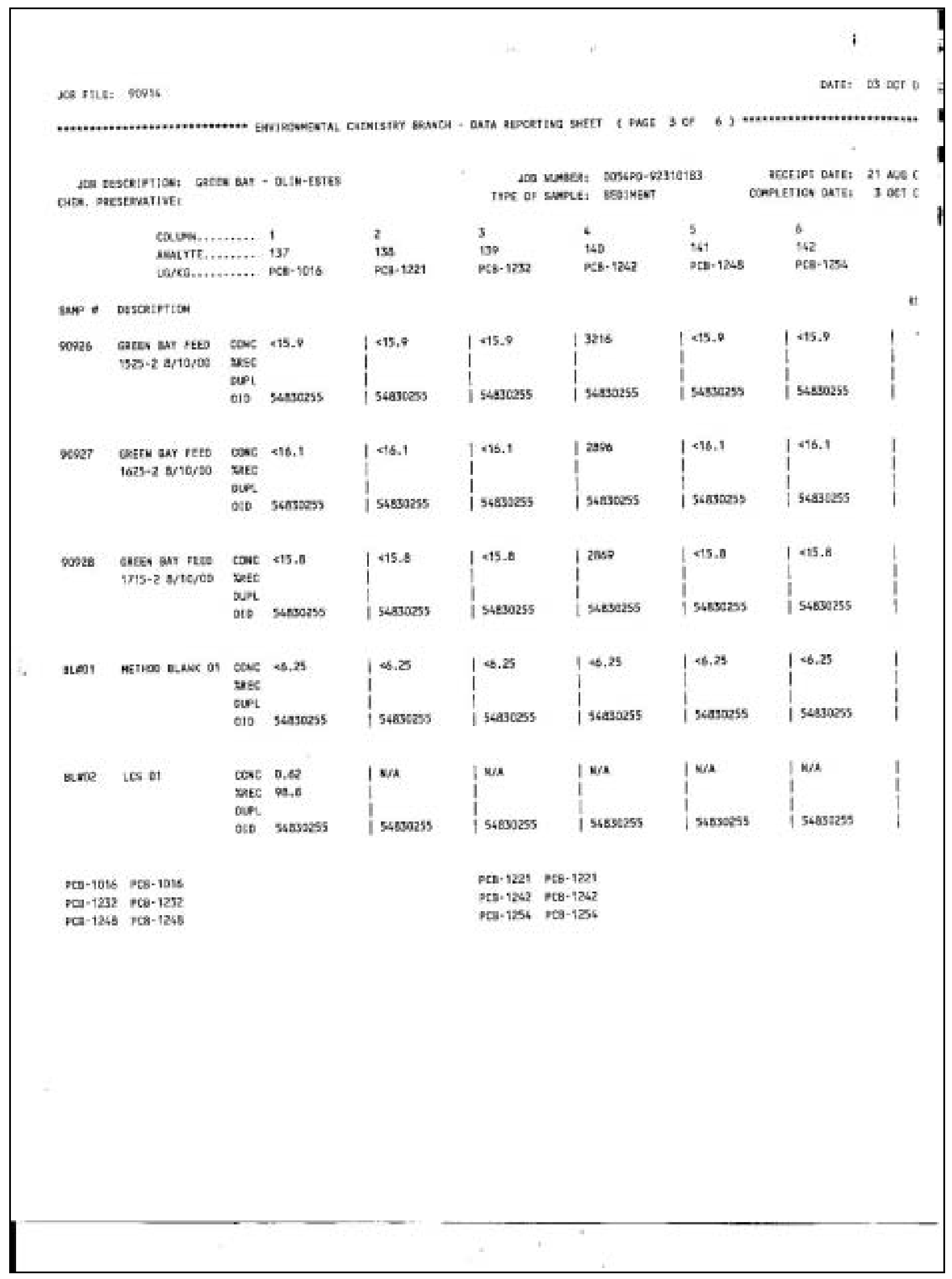




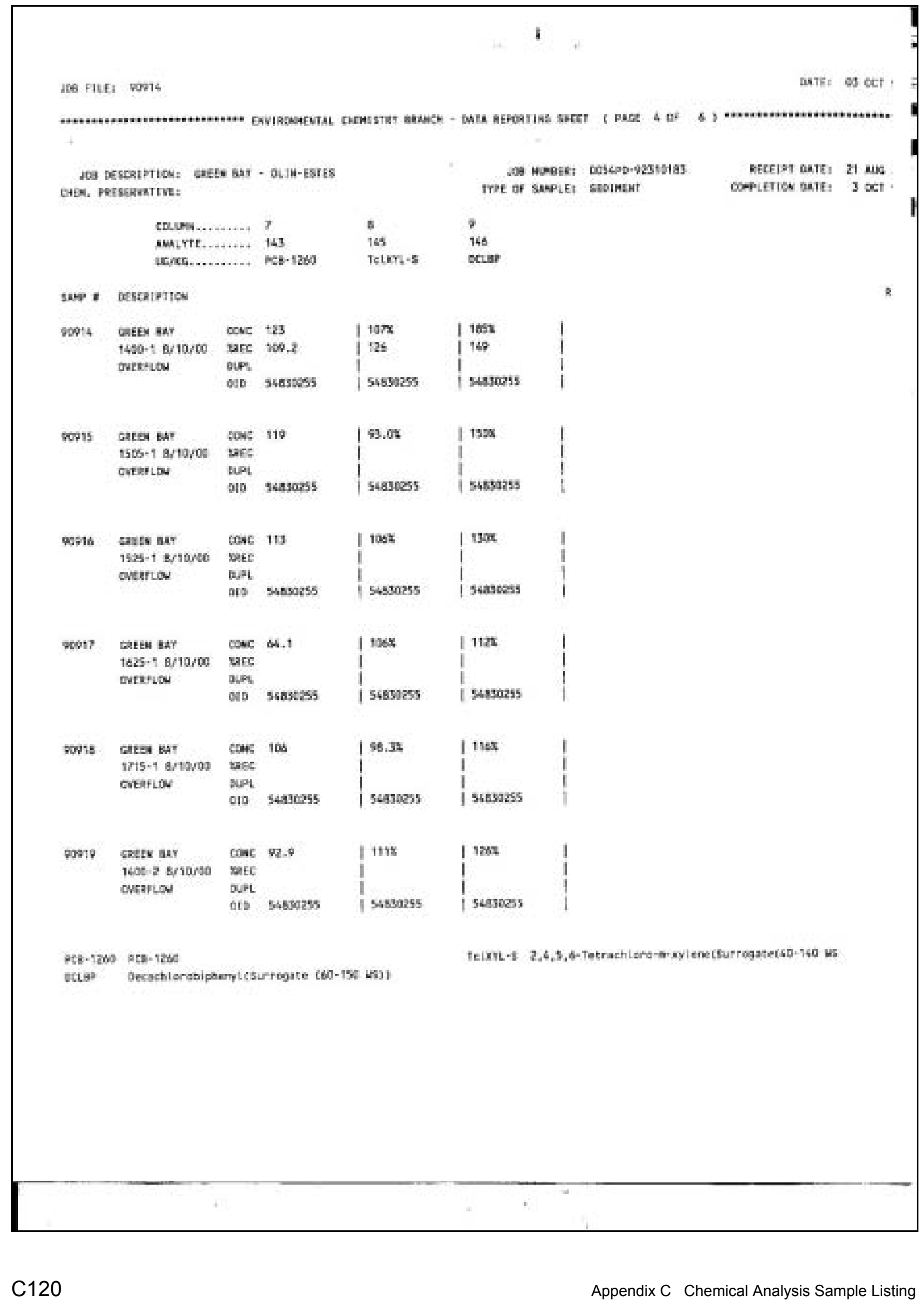




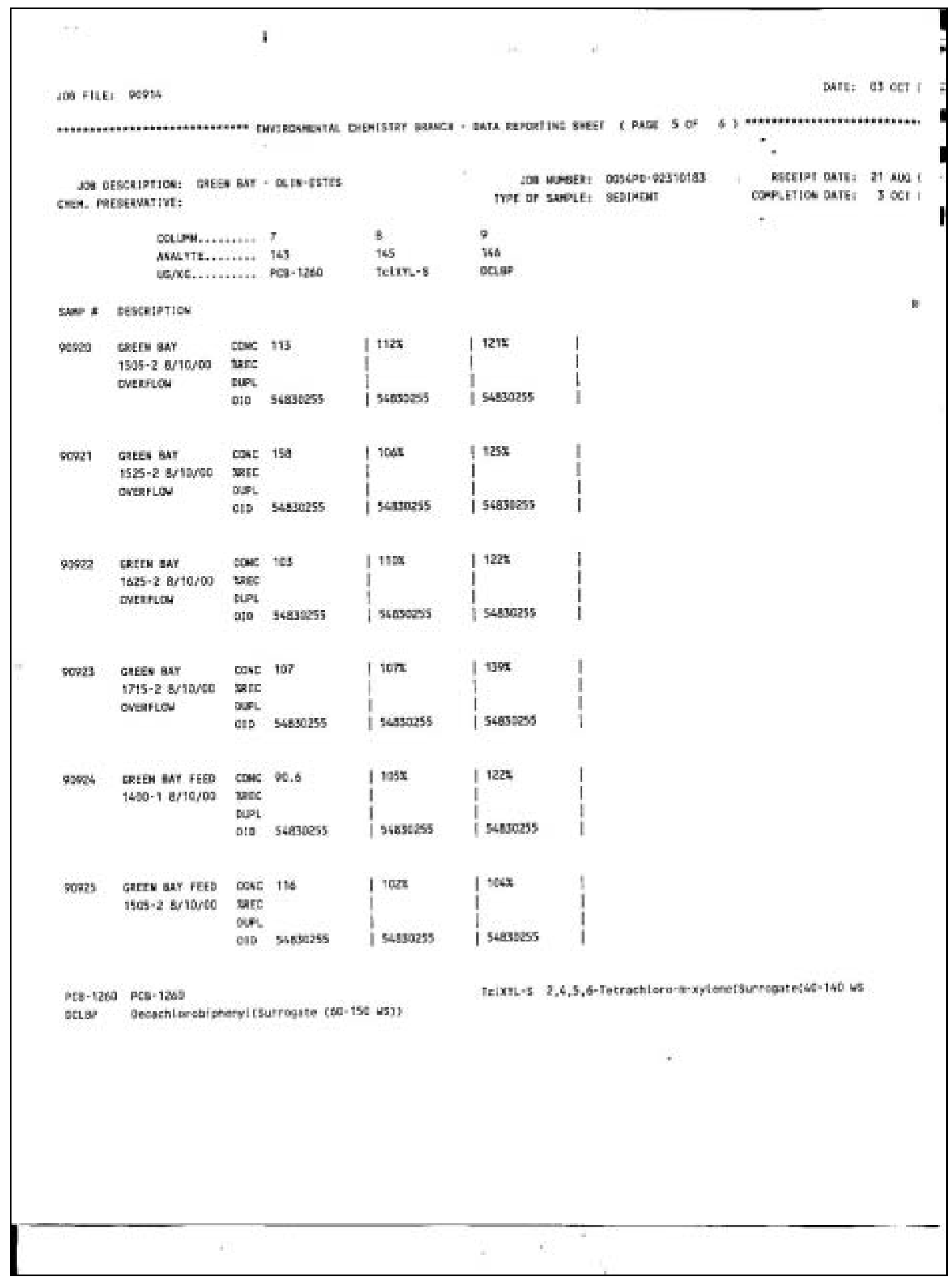


jo3 FliE; , poss

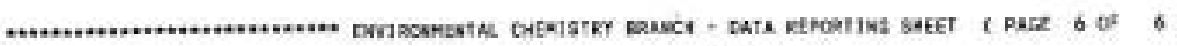
$+$

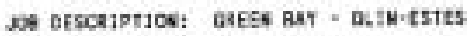
chem. pesescavirtiv:

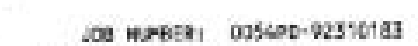
Trot of stretei setwikt

a. 9

145168

Aะเทีย. .

uarkt............ PCB-12ta

foim-8 sass atcrapt CATt: 21 NOO 4 COAPterIOA DATr: 3 oCT

satr $s$ sescription

\begin{tabular}{|c|c|c|c|c|c|}
\hline \multirow[t]{4}{*}{ esset } & SKEEH BAY THS & cant & 113 & | $110 x$ & 1238 \\
\hline & $1525-20 / 10 / 00$ & wet & & i & I \\
\hline & & DUPL & & I & I \\
\hline & & 010 & 54930255 & I subsoss & | 5480025s \\
\hline \multirow[t]{4}{*}{$\sin 27$} & theEs Bay fert & cesc & 135 & | nios & I 1200 \\
\hline & $1625-2$ B/IDSO & vare & & I & 1 \\
\hline & & oLF: & & & \\
\hline & & OID & 54834255 & | 56430255 & 15495025 \\
\hline \multirow[t]{4}{*}{96929} & CREEX BAP FEEO & cont & 103 & $10 \% 2$ & I $97.8 x$ \\
\hline & $1715-28 / 10 / 09$ & DeE & & 1 & 1 \\
\hline & & Dur & & 1 & i \\
\hline & & ats & 54430255 & | 5585t255 & | 54639255 \\
\hline \multirow[t]{4}{*}{ thet } & HET 450 SLAKK of & cove & 26.25 & | $36.9 x$ & $\pi, 2 \pi$ \\
\hline & & tar: & & 1 & 1 \\
\hline & & DUR. & & l & 1 \\
\hline & & OID & S4854255 & 154330255 & 1 54030205 \\
\hline
\end{tabular}

aLma Les a1

cove 0.61

खwec 97.2

Dart

$\left\{\begin{array}{l}\text { a7.25 } \\ \text { | stasess }\end{array}\right.$

$P C a-126 b, \quad r a d-1260$

$\left\{\begin{array}{l}72.7 x \\ \mid \text { sunseass }\end{array}\right.$

DCL

Dotactierobipnemplsarrogate $(60-150$ 65)

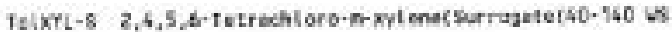




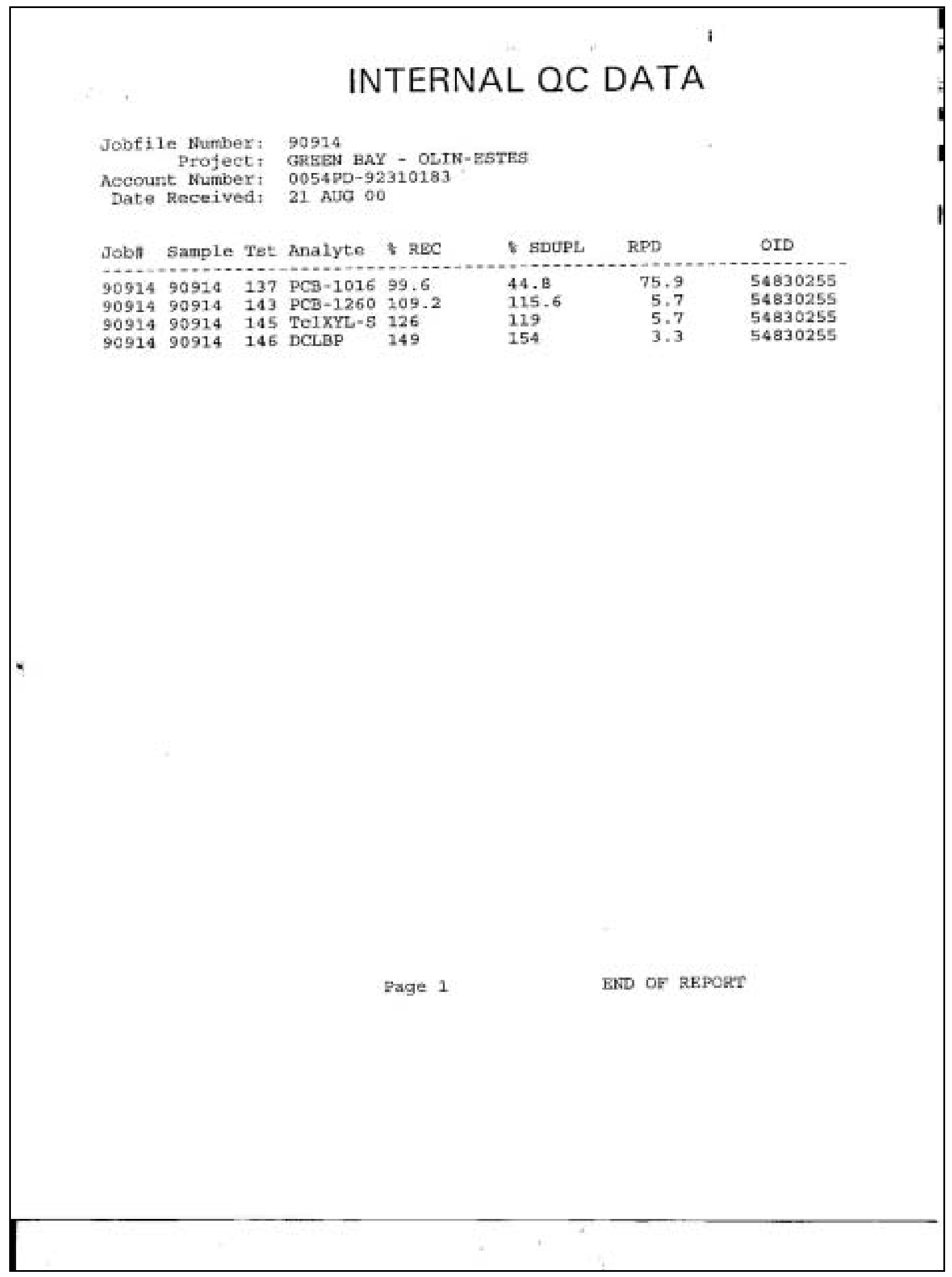


Je rilt:

DACE: is MaES

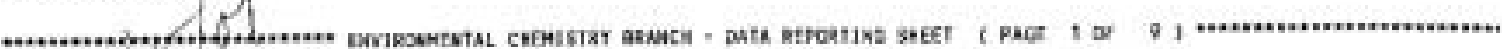

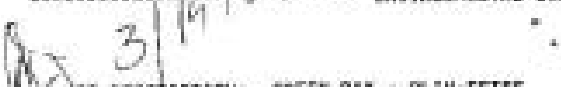

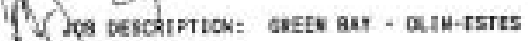
cHEsi neserntrve:

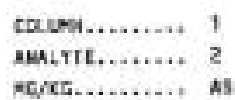

$$
2
$$

ecreg............ A!

2
4
0

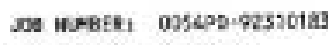
TrPE of SARPLE: SEDIACORT

NESEIPT DATE: 21 AUM । torhetice gate! it ma I

$$
6
$$

san \& descrintice

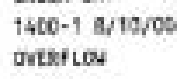

$\frac{4}{6}$

s
pe

153.7

woraso caces $3 a y$

1505-1 8/s0upo xare

ovteriou

$\cos 5.20$

cis a12कa27

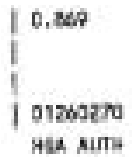

i

ot2s0270

hes wets

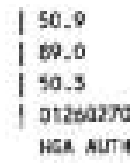

1 57.0

102.6

| 55.1

| 01260270

Hak airty

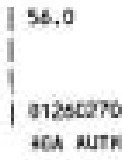

1 65,0

i

I

s126re?

rCA nute
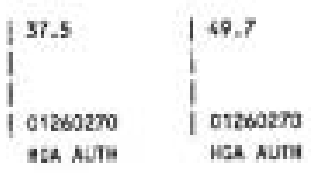

| 68.6

I

| $012602 \pi 0$

4: ลปTK

wa nutw
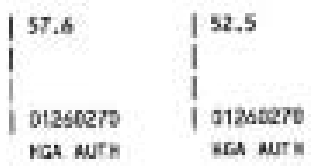

| 69.2

,

1625-t Burauce tarc

overice

OUFL.

CID 0126270

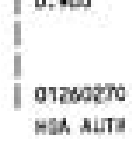

1 \$2.9

Gatea EAT CDWE 3.SO

1715-1 andos sore

overiotion
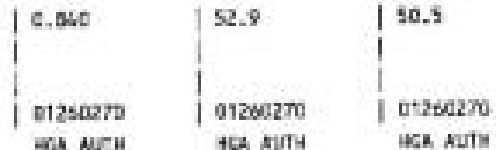

1

orzisizo

HIR ANTH

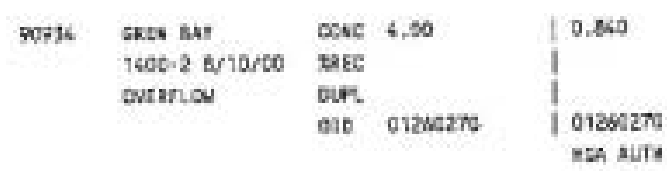
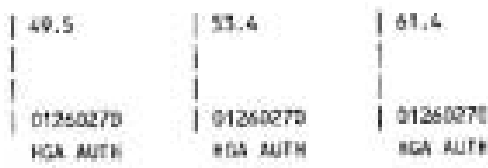

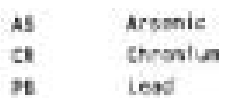

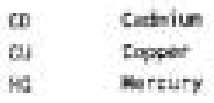




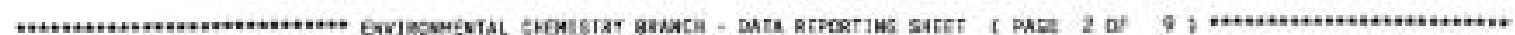

jos tesckiption; Gatk as + Dik-istes che- meseruatruer

$$
\begin{aligned}
& \text { caine........... } 1
\end{aligned}
$$

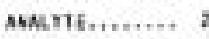

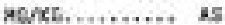

\section{2}

4 do3 แyesca; co56po-pastera TME OF SANLE? SFOIMEVT

3
5
ca

$\frac{6}{6}$
utEIPI DarE: 24 NoG । coobtitcs datt: 16 MA !

sas a zescurnies

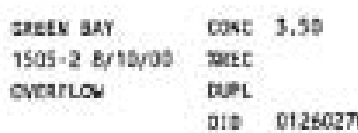
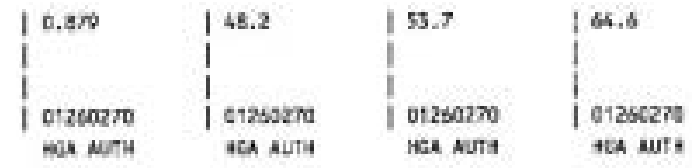

11.52

popss

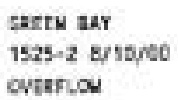

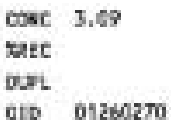

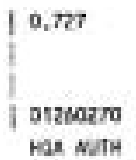

142.8 cto $012602 \pi 0$

92957 EREIM IAY

$1625-2$ a/ $10 / 60$ wate 90.6 DVFaricu

oun 3.60 ato 0:26azo

gcoss ratra car

$1715 \cdot 2 \mathrm{~g} / 12 / 60$ a curertioy

canc 2.69

ate

our 010 012620

0.957

195.8

0.957

orewarro

45a AirtA

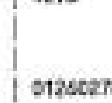

012sc2 270

| 42.6

I

01260270

iEa Auth

199,3

192.9

159.2

I Dtzsozk

acs arta

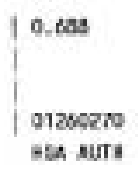

143.7

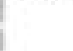

ov2ecto 10 los Nite

52.4
as.
52.5
| a12at27o
nea nuts

| 54.3

I

| $012500 \%$

tha auth

167.2

| 96.2

167.8

10250070

tos MarH

| 38.3

I

I

| 41260270

sch surk

140.4

01260270

was WITH

90957 Getra Dä reED cow: 3.20

$1600-28 / 10 / 00$ was:

o10 9126027

$\left\{\begin{array}{l}0.738 \\ \text { andesore }\end{array}\right.$

| 4.3

i

a 1280270

15. ANTH

48.5

I

3260070

that eurn

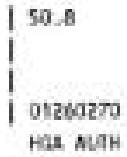

sont cares an rom cont 2.76

1505-2 aldopt watc

cul

nis 01250270

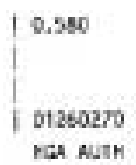

$\mid \begin{aligned} & 37,7 \\ & \text { 91204270 } \\ & \text { ASh Auth }\end{aligned}$

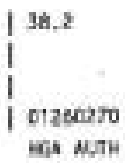

41.6
| c1250270
Han surt

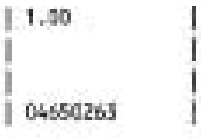

$\begin{array}{ll}\text { Ca } & \text { Evariua } \\ \text { ou } & \text { tupper } \\ \text { He } & \text { martury }\end{array}$ a

nz I 04654263

| 9.59

( 06650253

| 1.31

( 100.7

1.33

| 2605005s |

0,370

cesscass

17,11

I

Dessazes I

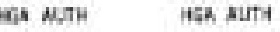

$\begin{array}{ll}\text { is } & \text { arsenic } \\ \text { cs } & \text { throetin } \\ \text { id } & \text { Lead }\end{array}$


xet ine: qeves

e.275; 14 ket

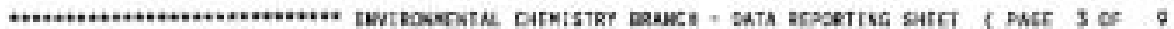

AD Deschifitom GREM BAY - QUN-Estrs cath. pesceavartue:

$$
\begin{aligned}
& \text { co.ums........... } \\
& \text { MALrE........? } 2 \\
& \text { merke........... As }
\end{aligned}
$$

\section{2}

4
JSE AMBSR: COSAF-9231915S THFE of MNPLE; SEDINOVT

3
5
6

\section{5}

cu

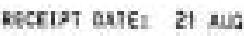
COPFETICA EAIE: 14 NAR

sum sescention

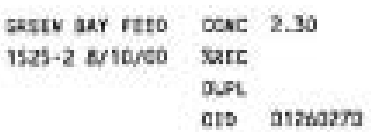

10,020

1

1

astaznd

$\mid+0,160$

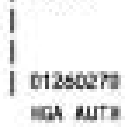

is. 000

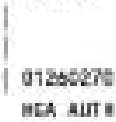

| 0.102

I

1

ot250270

EA N-TH

6
6
16

16

Btros tes ot

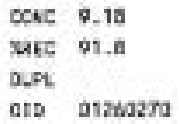

\section{| 4.50}

1 96.0

1

I costazos

w5a Auta

| 21.5

| 107.5

I

I v1260ers

ras aurs

\section{7}

98.5

a124003

a1260875

10.9

I 100.0

I

01260270

ECA A.TH

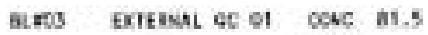
eacc
aเอ 09249270

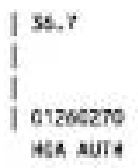

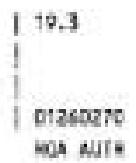
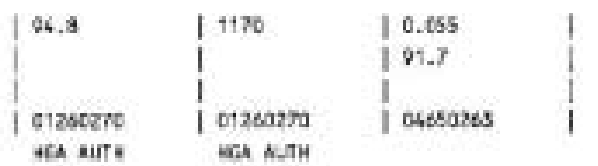

As ataenit

Ca Dhrenitu

pa last $\begin{array}{ll}\text { to } & \text { Camliar } \\ \text { to } & \text { Copoef } \\ \text { bo } & \text { Heroury }\end{array}$ 
Ita PILE: 60028

EATE: 14 Nas 1

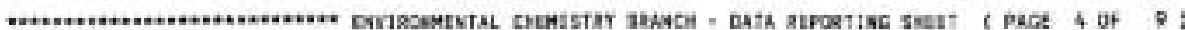

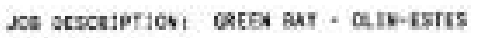
cith. passawative:

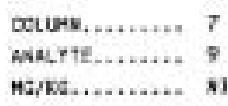

save aIscription
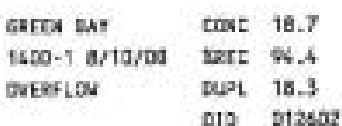

oro 51260270

vas Nirn

$\$ 0930$

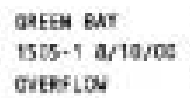

$\cos 21.3$

ThE5

Dual

010 D12:0azo

ics NSTH

Sov31 GLES bar

158-1 artovos

aveartos

cose 15.5

yeec

pupt.

ors Distazro

ตCa N.TH

90932 GeE BAT

$152-1$ MINOS

evenfLov

$\operatorname{cosc} 19.9$

WREC

nist

atp ovecazro

Iอง NगTH

90733 weEs Bar conc 20.3

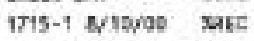

CVERTLO

DUSL

atD D12งazse

Mat Aurs

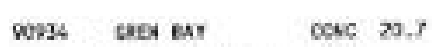

1401-2 s/10reo жасC

ovearloy

oun

atb 61265270

H5h sul

10
IE

¿o4 wants: 005600-92310tas TYPe af sapit: subintst

8
11
10

10

I4
32
RECEIFT CAFE: 21 AUG I COMLEFION BATE: 16 WNR I

12
30
12

a)

\begin{tabular}{|c|c|c|c|c|}
\hline 10.600 & 15,093 & 1115 & 178.1 & 1easo \\
\hline 04.4 & | $\$ 5.9$ & 194.0 & | 101.6 & 116.0 \\
\hline 0.650 & | e.492 & 1175 & 17.4 & $108 \times 0$ \\
\hline 51260270 & | $612532 \pi 0$ & $012612 \pi$ & 01250070 & $8173067 \%$ \\
\hline
\end{tabular}

acA aut

$\sin 20$

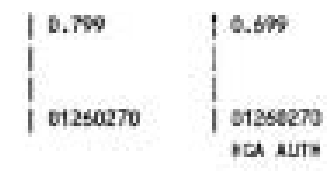

12507275

190.2

I

(1)

21130

orestors

19620

I

i

|

i to.sosects

194.6

I

1 91260270 I p12emso

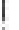

otzsegr

$\left\{\begin{array}{l|l}0.700 & 0.550 \\ 01260270 & 01260270 \\ \text { net aute }\end{array}\right.$

$\mid \begin{array}{lll}152 \\ 01250270\end{array}$

I sa.6

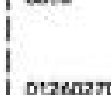

| 1 azco

$012602 \pi 0$ | otasesn

\section{$0.5=0$}

10.609

1

| 012serm

nen auth

| 125

10.0

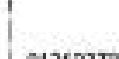

02.0

$10 \operatorname{sen} 20$

I lasso

926027

1012620

| 0123027

1 a.sot
1 arencento

0.560
I costart

$\left\{\begin{array}{l}124 \\ 01250270\end{array}\right.$

$\left\{\begin{array}{l}6.9 \\ 012602 \pi\end{array}\right.$

130600

I 1 HES MrH

$\begin{array}{ll}86 & \text { Selentun } \\ 24 & \text { zine } \\ \text { HE } & \text { Iron }\end{array}$




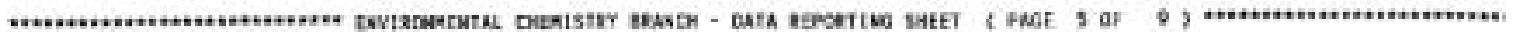

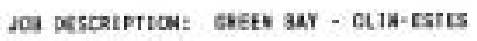
Dird, pesstonatrve:

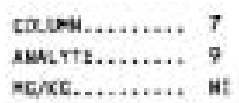

SAAP * ACSCE!PTION

90955

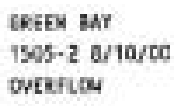

90037 Gates 345

COAC 20,6

creviod det ro.s

ors Dtzeazro

Mat Auth

50035 caess axt

$175-2$ av90yos

oveafleu

$\operatorname{cose} 16-0$

ज्ञात

DUR.

0:D 0t250270

wa NuT

Sos39 SECE GAT FEED $1400-2$ a/moce

Cok:
ares

otD a12sezte

Gose caEeY BAT FEED $1595 \cdot 2$ a/ $10 / 00$

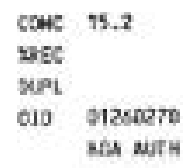

W1 Sickel

A5 silve

ai arian
-

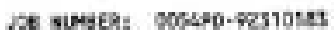
Teve of sarole: SEDTEVt

सEREI CATE: $\lambda$ N W I COAPLETLON DATE; 16 WH ।

$\begin{array}{lll}* & +10 & 11 \\ 11 & 15 & 25\end{array}$

at

24

b.

58

$\left\{\begin{array}{l}0.609 \\ 0125 n 2 \pi 0\end{array}\right.$

| 0,5 to

I

I c1zenzr

Hea AITH
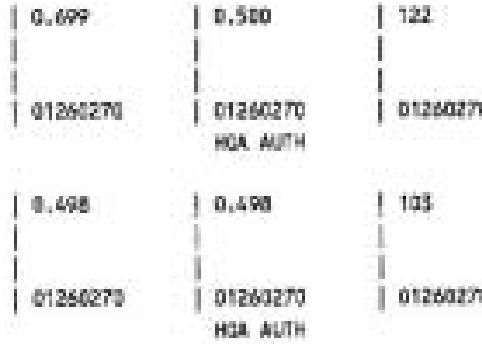

160.2

0123027

193

1

atsogen

[7.0

I

1

17300

I

10.

HaA AUTh

\begin{tabular}{|l}
0.767 \\
63.5 \\
0.727 \\
01260270
\end{tabular}

10.593

105.4

1 0.598

| 01200270

ish surs

$$
\begin{aligned}
& 135 \\
& 105,0 \\
& 100
\end{aligned}
$$

d d 1200270

I *6.o

| 91.6

| aว.5

| 0126a27

72.0

15002

| 1253271

$\left\{\begin{array}{l}0.499 \\ 109260270\end{array}\right.$

10.098

i

| 9125027

tca Murs

| 6.

I

1 $612502 \%$

| 67.0

e1266270

I 15800

I

( 125027

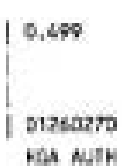

| 107

I

I

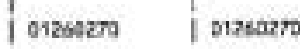

f 01260270

17.4

bath

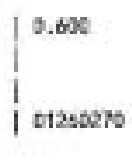

$\left\{\begin{array}{l}0.400 \\ \text { 01260270 } \\ \text { nas Auta }\end{array}\right.$

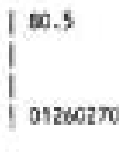

| 51.9

I

I

otzsarm

1. $195 \%$

I

0123027

5 betenive

a tinc

rt Iran 
jot int: sopze

DATE: 36 Me:

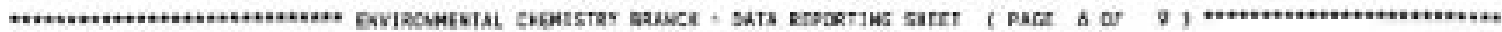
=

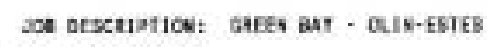
catm. paestavativet

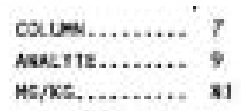

sup

95\%)

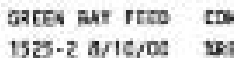

$$
\text { EUP: }
$$

DI0 o12scart

soh asrk

9OL? GAEEA BNT FEES CONE 13,4 toz-2 a/ta/00 wet

wete
SLPL

aid 012s0870

tas vir:

9o043

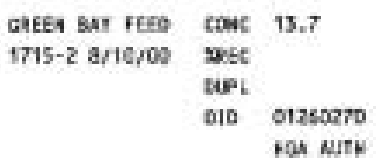

3เลง

METHCD GLANE 21 soac e0,100

getc

pisi

010 p12s0ro

ros aik

3tต02 LES 01

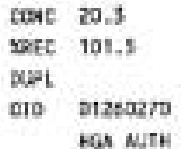

sLaj Exteasat oC a1 cose is.s

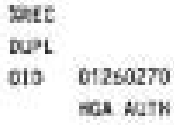

N1 Nickel

AS silwer

a. Bariun

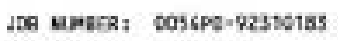
THPS of SAAFLEI SEMIAENT

atctipt DAIE: 21 NUE crasirtina DATE: 14 Mas.

$$
\begin{aligned}
& 12 \\
& 30 \\
& 55
\end{aligned}
$$




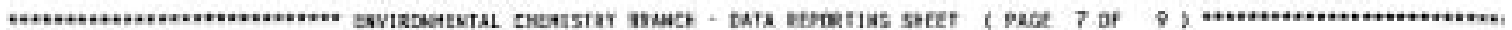

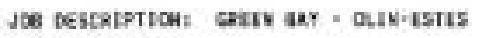
chet. neserutriv:

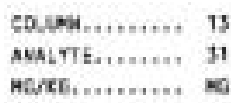

sava a sescripises

$\$ 0029$ Gates Bar
t60a-t sytspos
dventov

cove 20050

twetc 94.8

burt 2030

Dis ot23027

scoso Gaess way

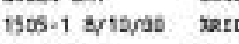
QUERTLV

cose 19020

bapl.

dis 51230271

$\mid 433$

I

1230271 01230270

sops1

Gaces aAY Cose 1 raso

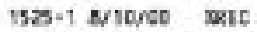

avrorior

viol

do 0123027

$+304$

I

I

5230077

doe vuset: 0054po-92stotas

TIPE of seave: sesimext

heceipt ante: 21 Aug i towtition Dates if wes a

$\begin{array}{ll}16 & 15 \\ 37 & 53 \\ 12 & \text { 10 }\end{array}$

$\left|\begin{array}{l}0.250 \\ 01230270\end{array}\right|$

Gaste way

cose 16550

ies-t spityet

overice

Dis ot2sozr

| 359

I

\begin{tabular}{l|l} 
& 01200271
\end{tabular}

sopss certe nay

Irts-t seriterco

$\operatorname{cosc} 1$ neto

OVRTLCV

sate

ari.

dis 0123027

| 372

I

1

| 01230271 | 01230270

sogsh GMOA RAT

น600-2 Nipoco yatc

ESAFLO

$\operatorname{cose}$ ascon

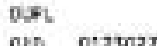

$\left.\right|_{1013} ^{4+3}$

$\left\{\begin{array}{l}0.500 \\ 10.230270\end{array}\right.$

i

Ni. Rayresin

no Malyboctive

w

Noraruse 


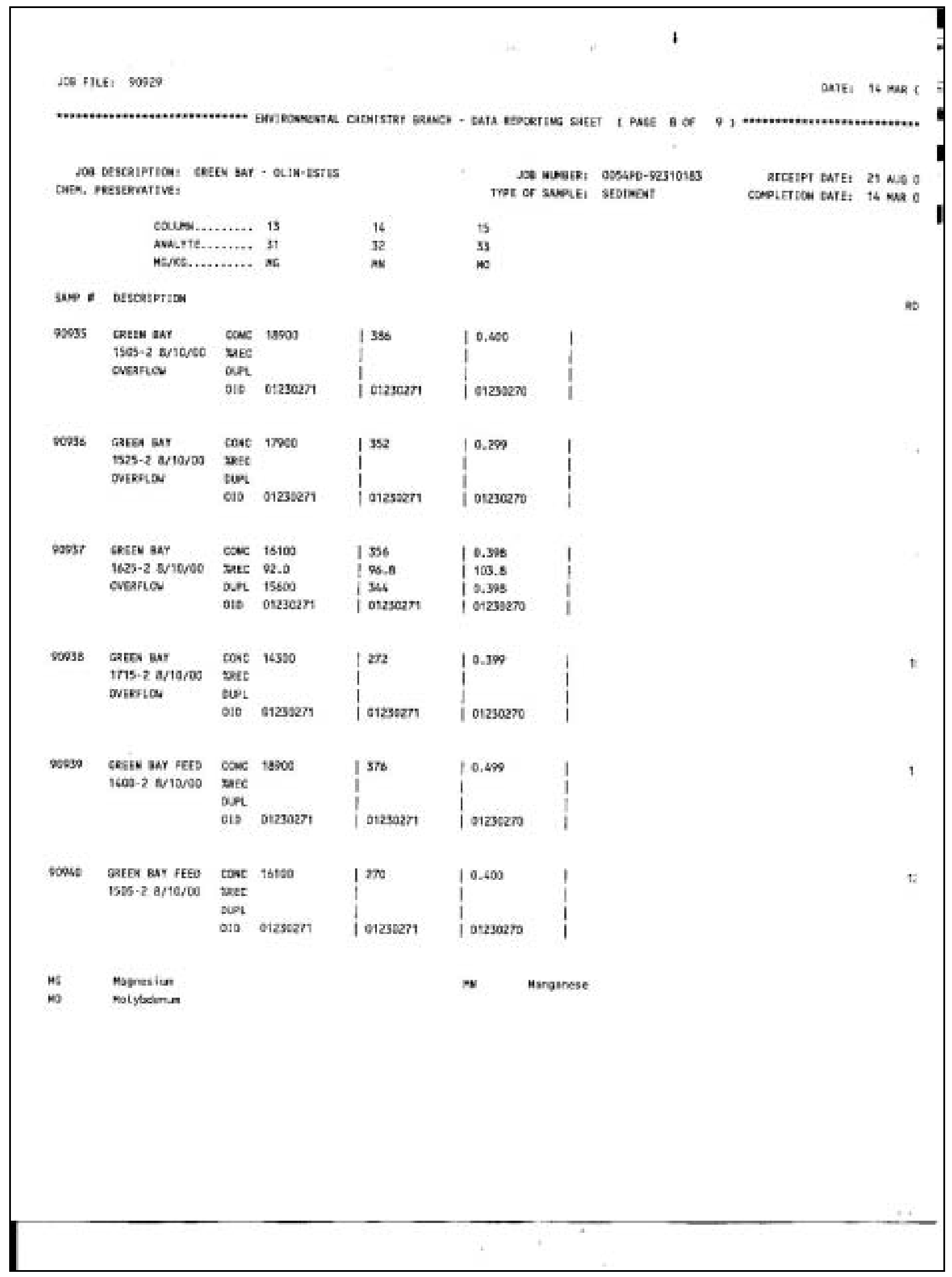




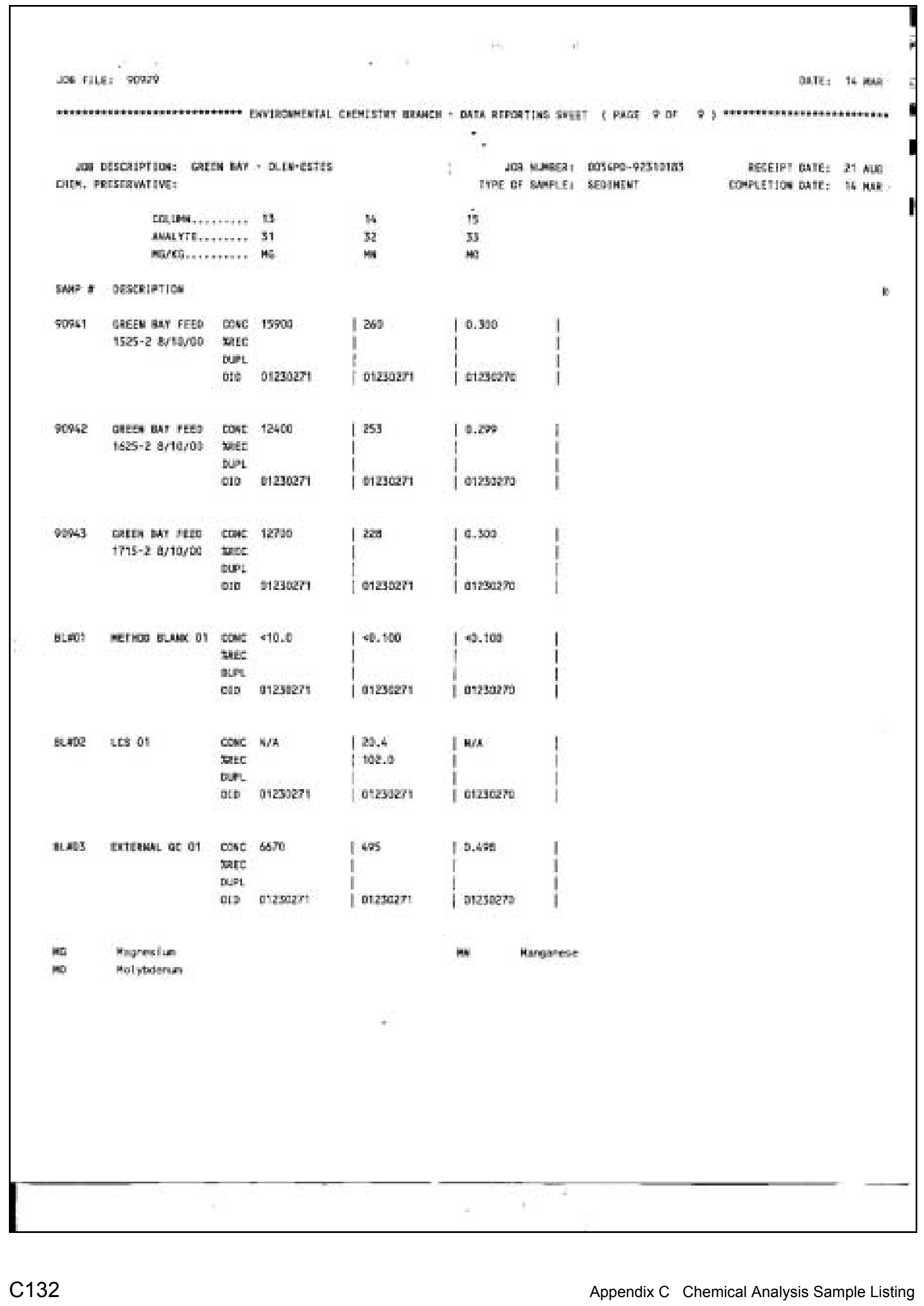




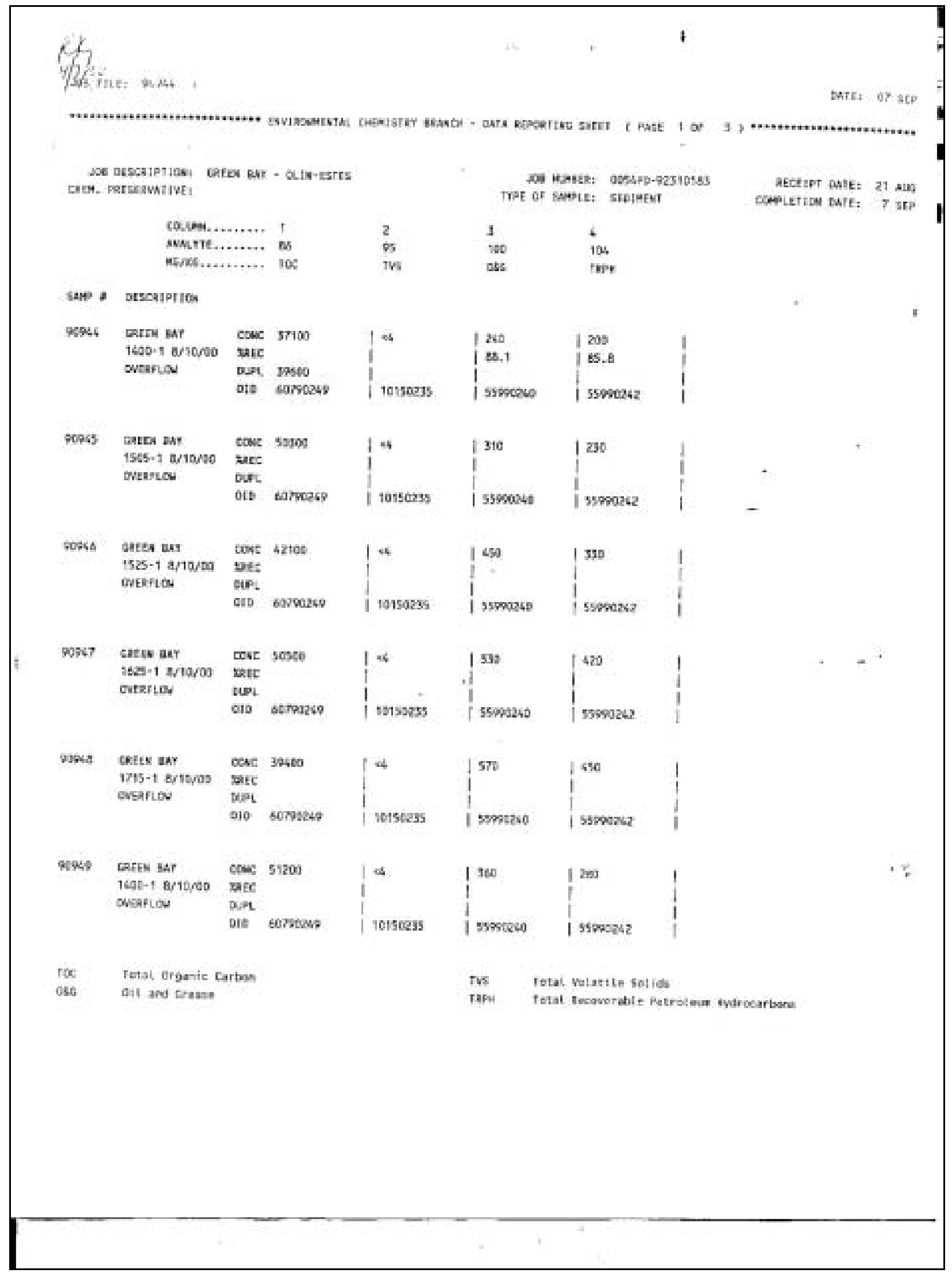




\section{1}

dea 611 :

DATE, GT SET

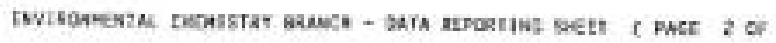

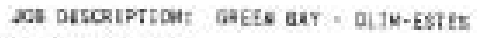
DAEM. PRTSRERTIVE:

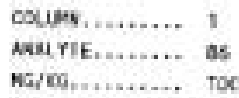

supe $\approx$ bescerptick

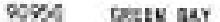

$150 \mathrm{~s}=2$ throvon

ourarion
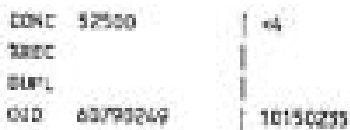

G5PI GAfen aAr $1525-2$ 5/10yoc GNEALOU

cose $4 a c 00$
wift
tup
olo bornoss

145

1

10950235

sops

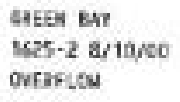

parss uets ant $1715 \cdot 2$ ariagos everiod

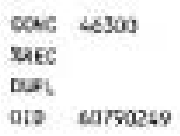

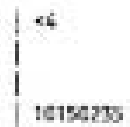

$\left.\right|^{290}$

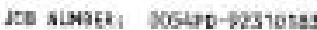
TYpt or sape: sEDIAEst

$\begin{array}{lll}2 & 3 & 5 \\ \text { is } & 103 & 126 \\ \text { rvs } & \text { cos } & \text { res }\end{array}$
$x$

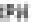

tove 4 kass

we:

Dun.

1360

I

n.t.

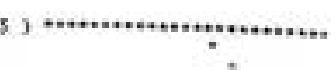

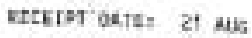
conctice eatl:; 7 ser:

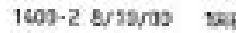

cupt

osb tarsozse

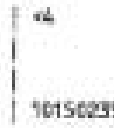

sosioeso

$\mid \begin{aligned} & 280 \\ & \text { | } 5580042\end{aligned}$

Ooush GeEN taY r

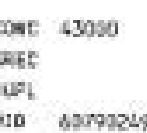

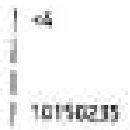

1360

I

Isescosis

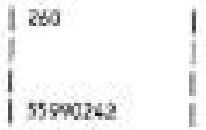

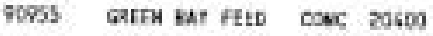

tscs-2 $8 / 10$ oro

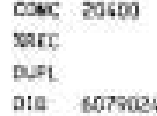

$\left\{\begin{array}{l}66 \\ 10580235\end{array}\right.$

$\left.\right|_{1500} ^{2500260}$

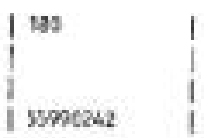

106 Total Grganie Carbon

045 Oil and Oreme

tus Tatal keterite solies

raps Total Rocowerable Fetrollen inydrecarbons 


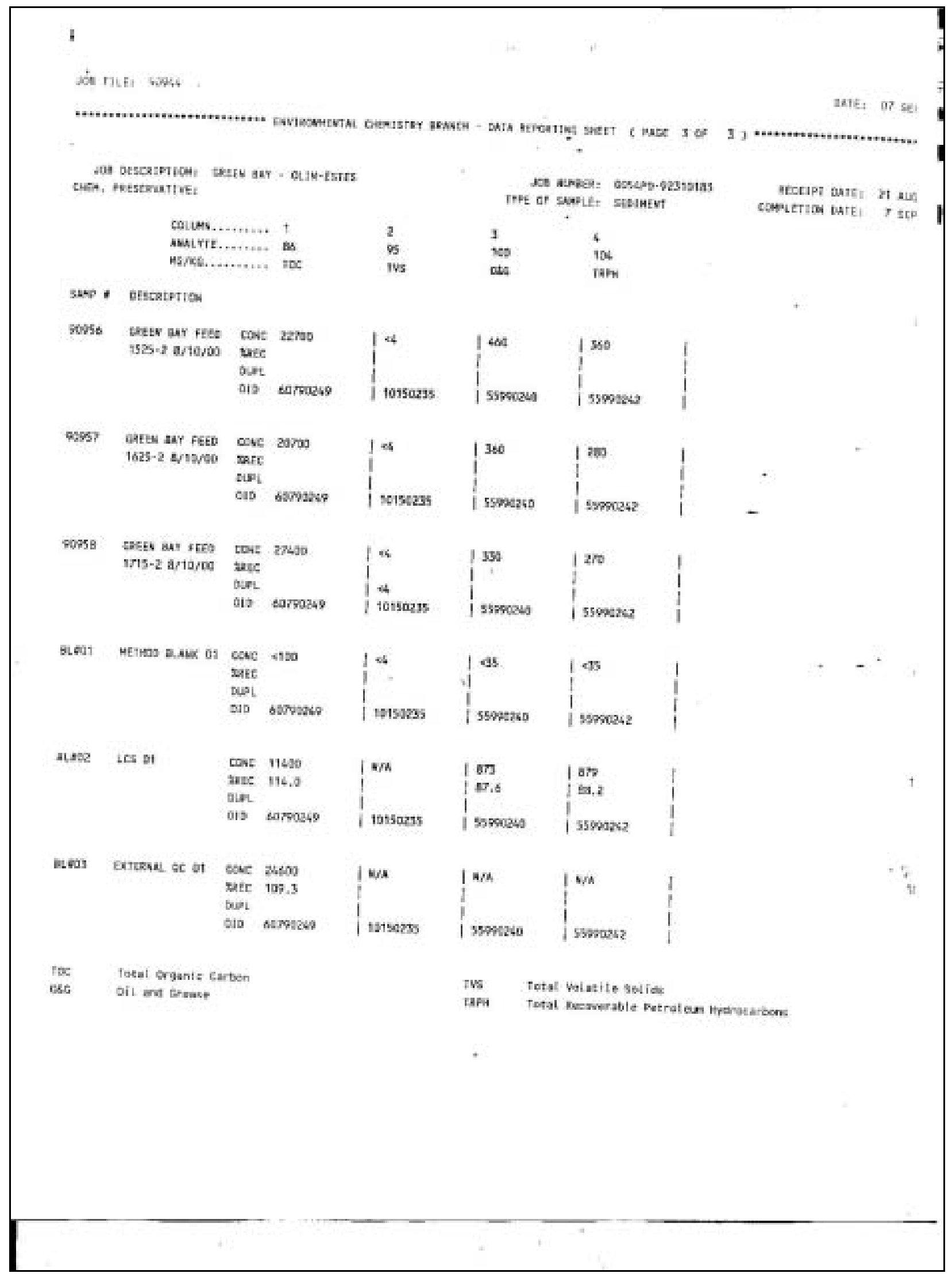




\section{INTERNAL QC DATA}

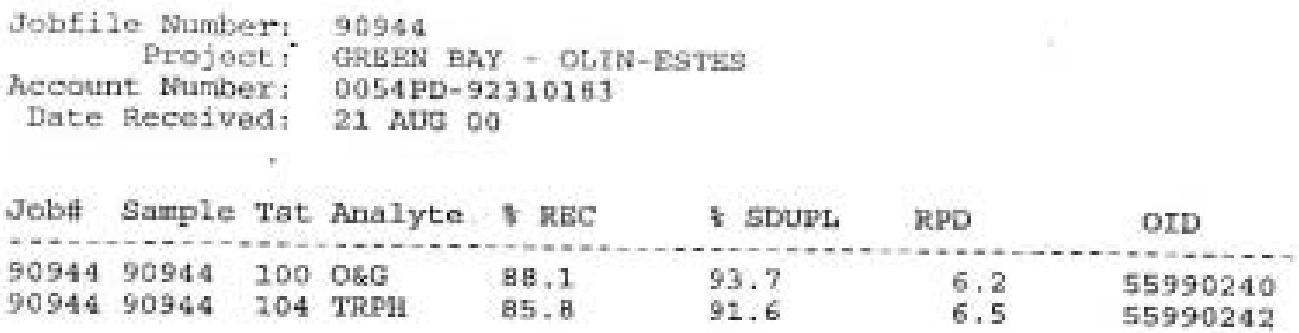




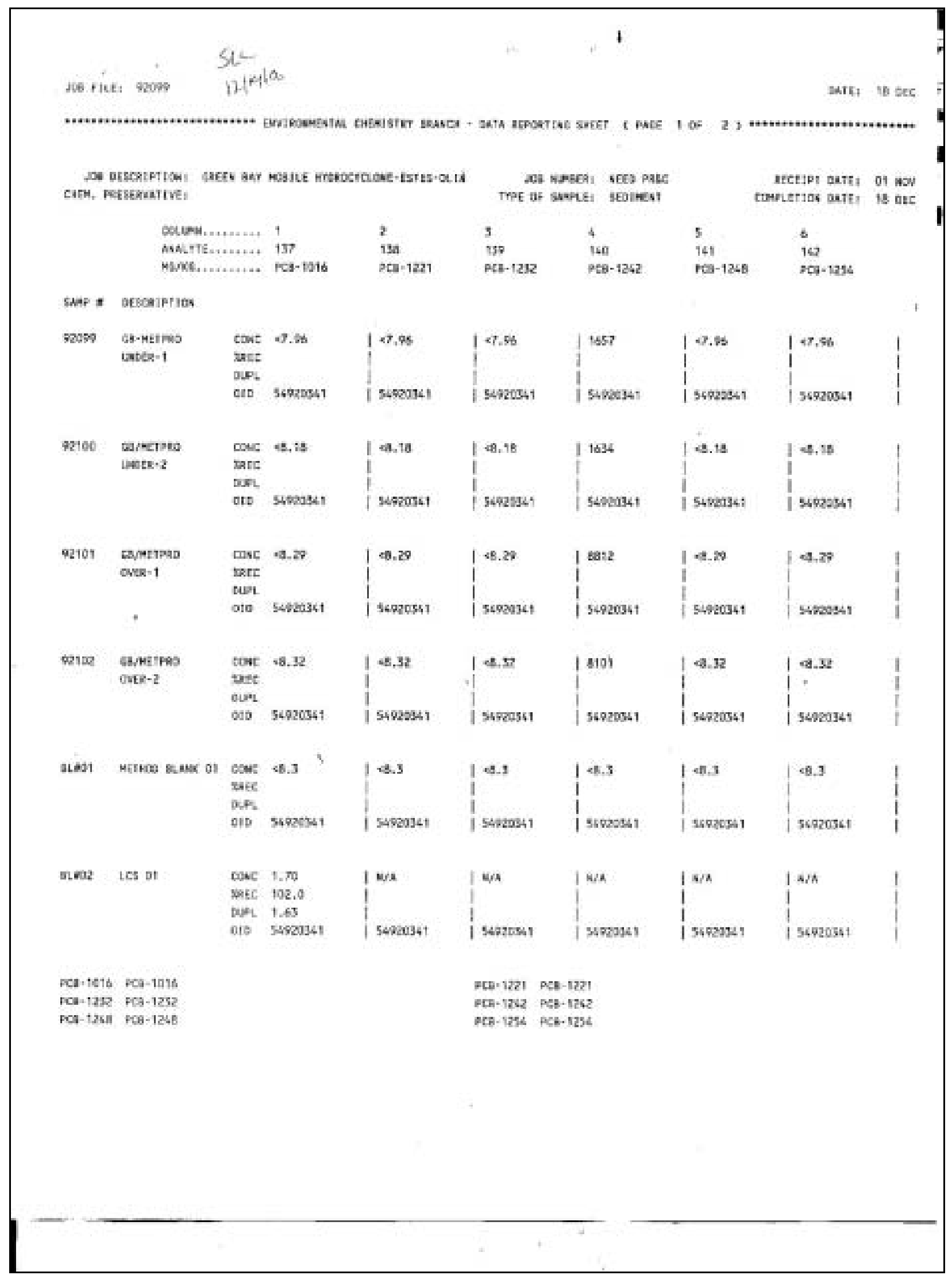




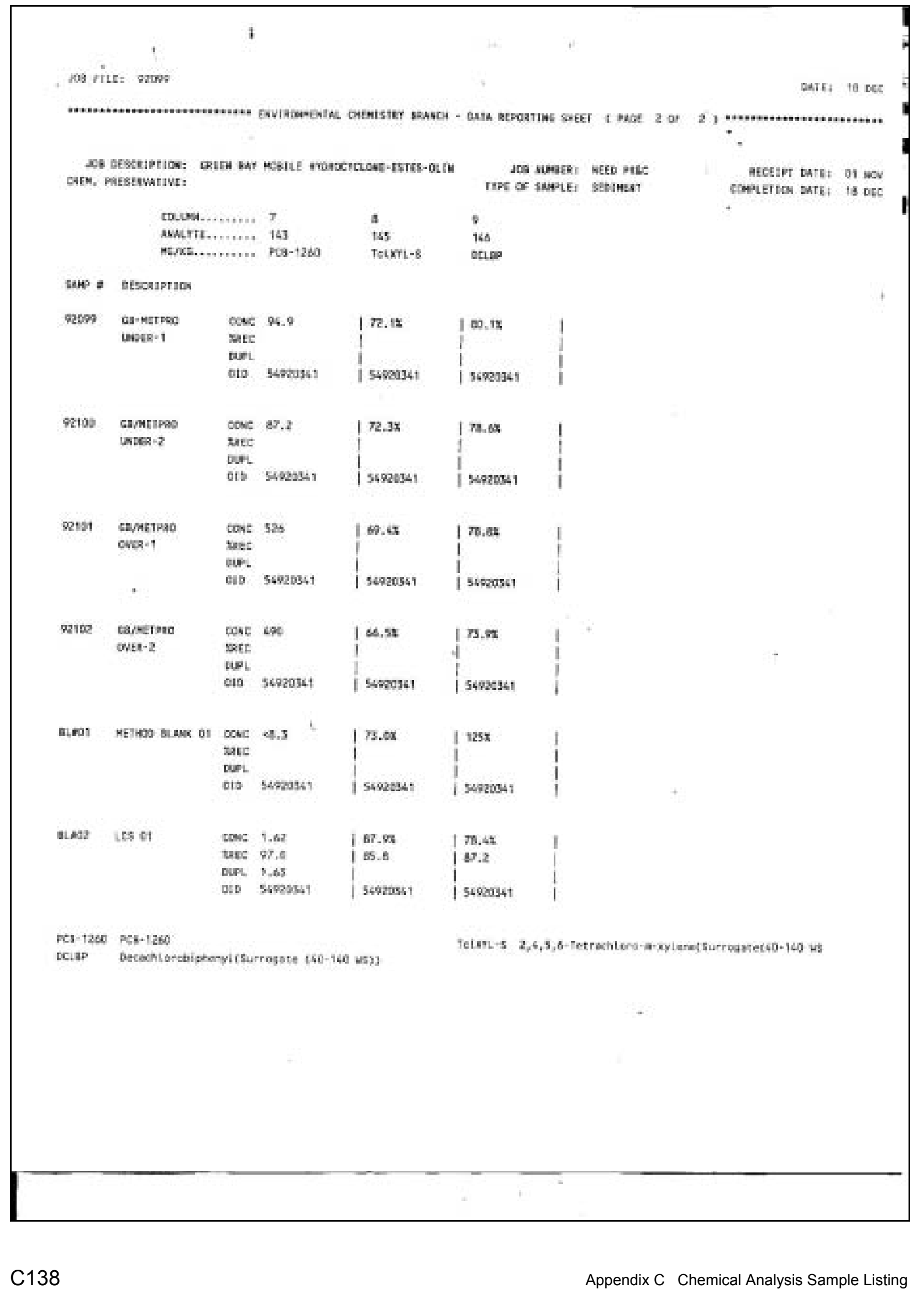




\section{INTERNAL QC DATA}

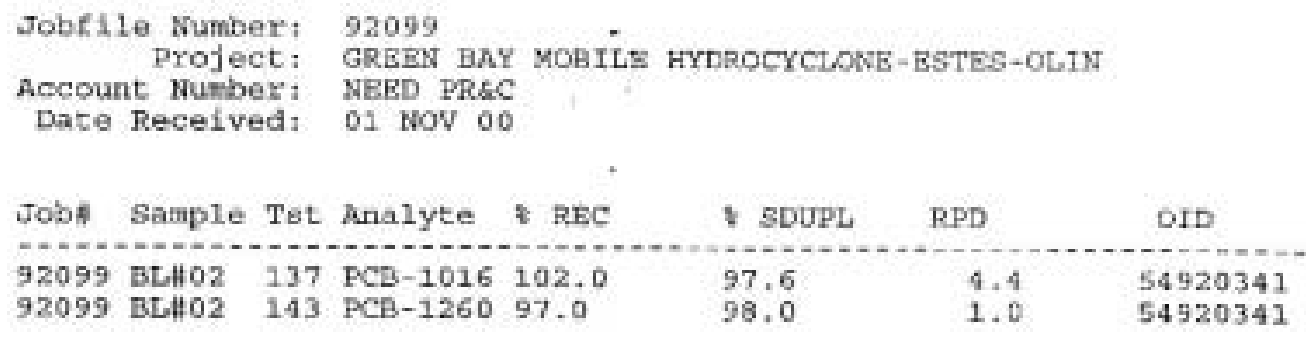




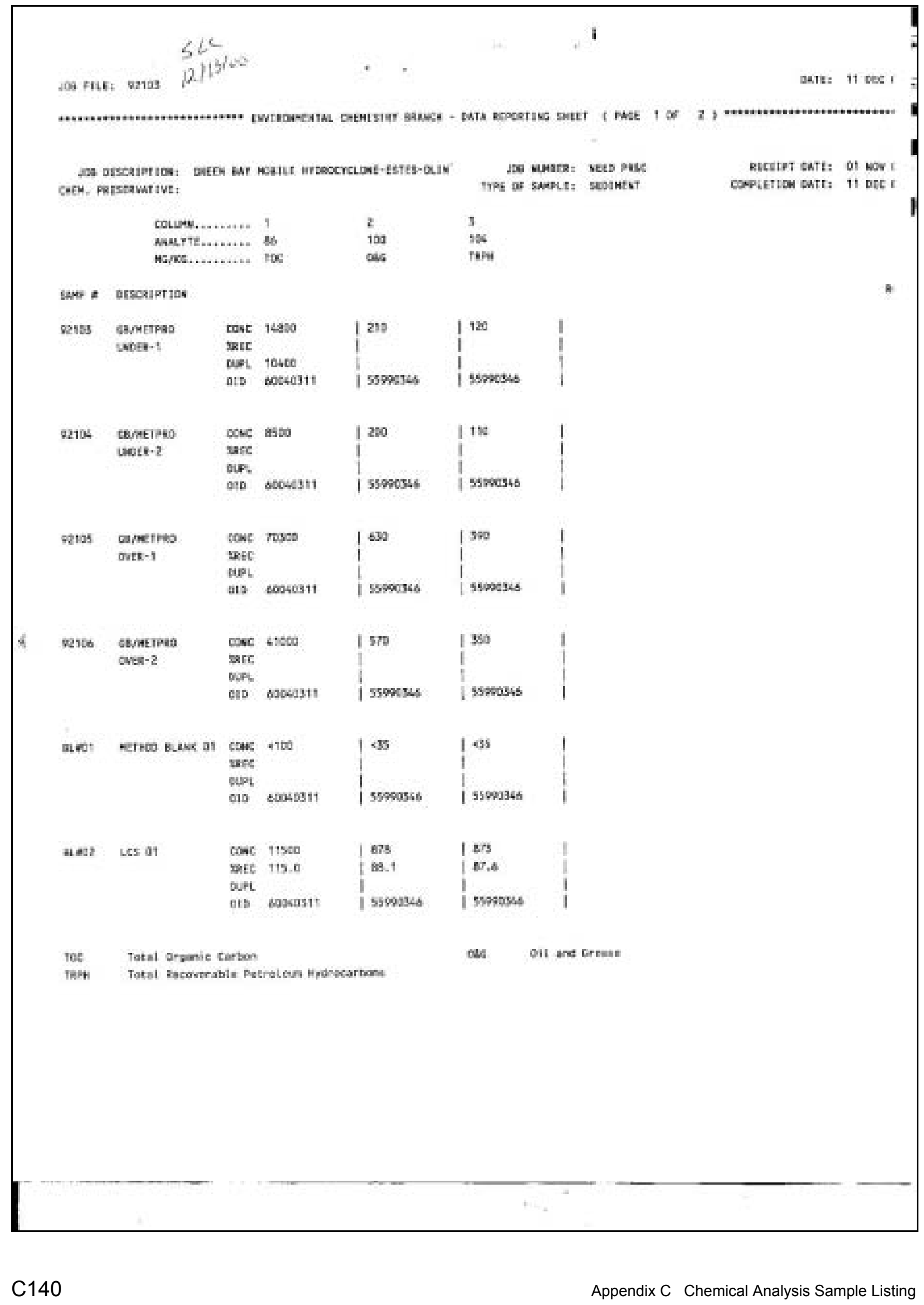




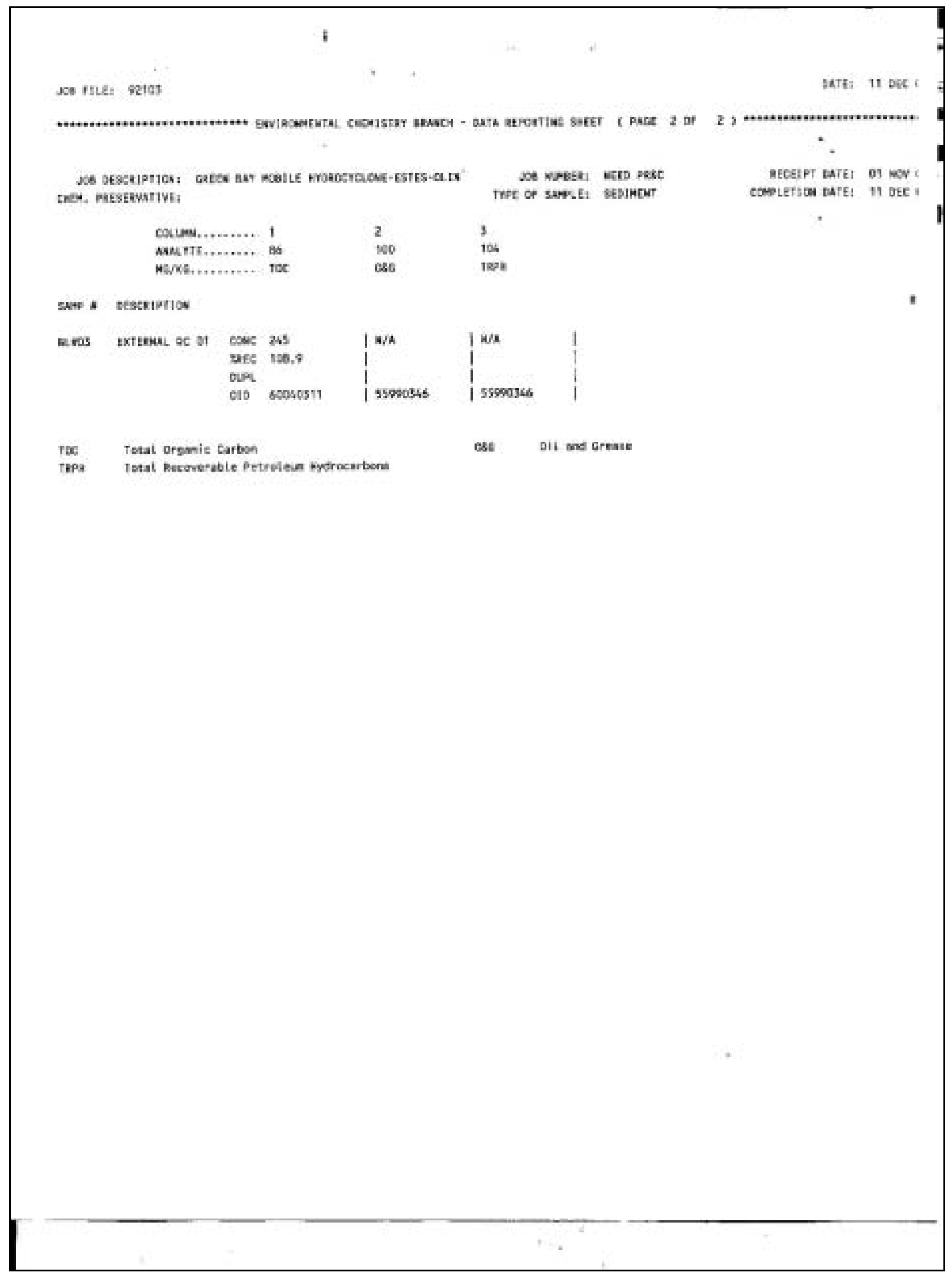




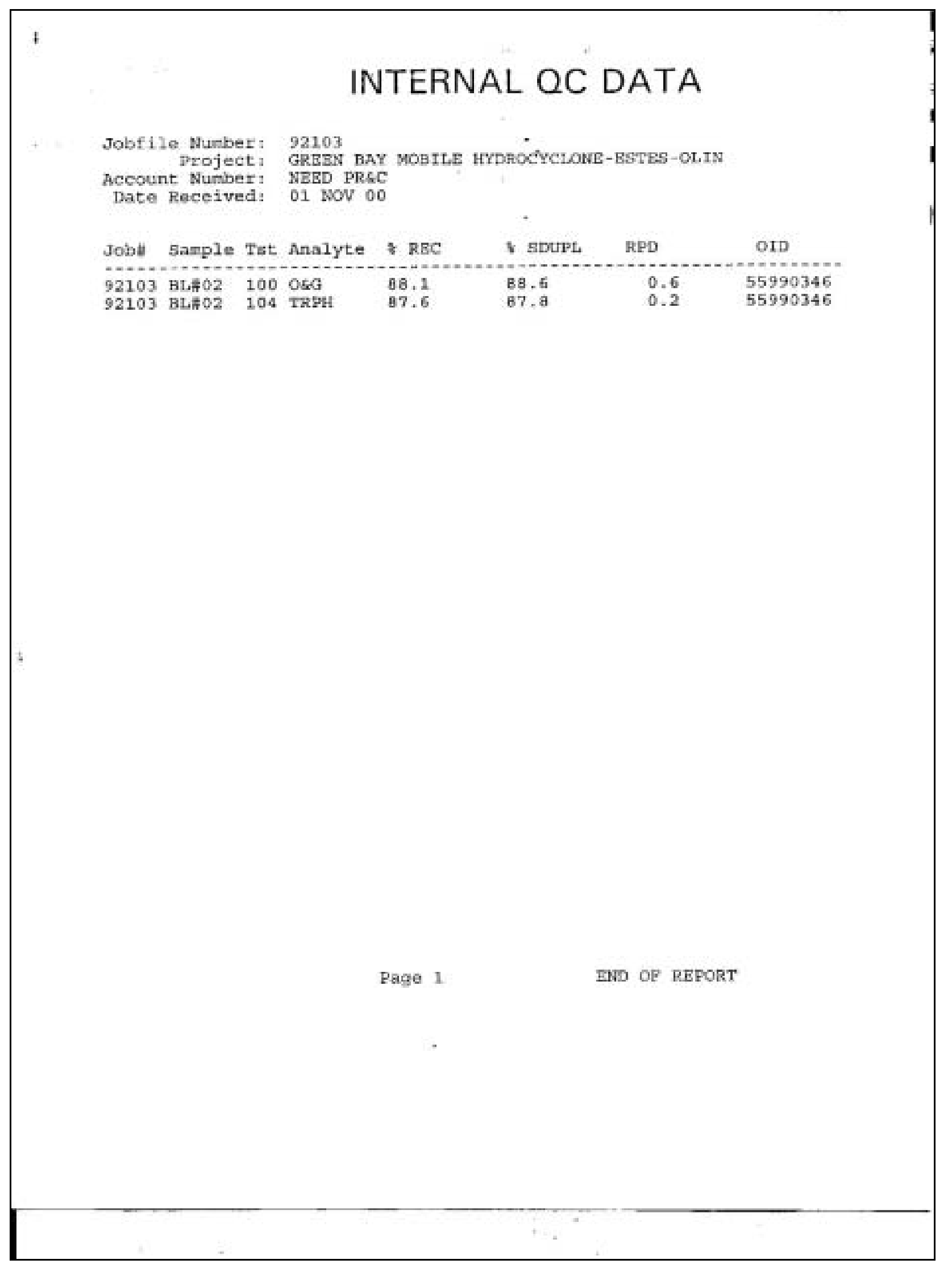




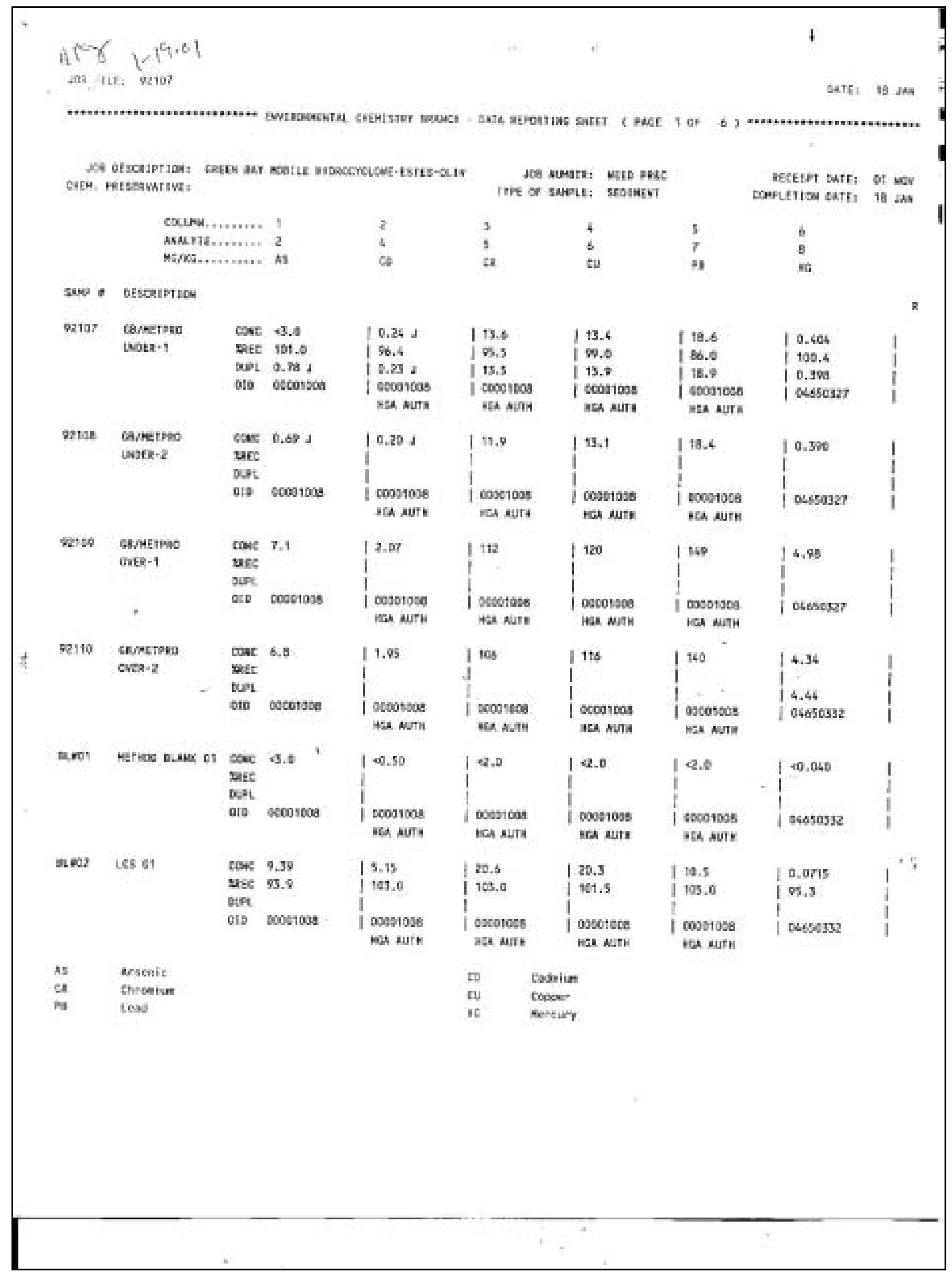




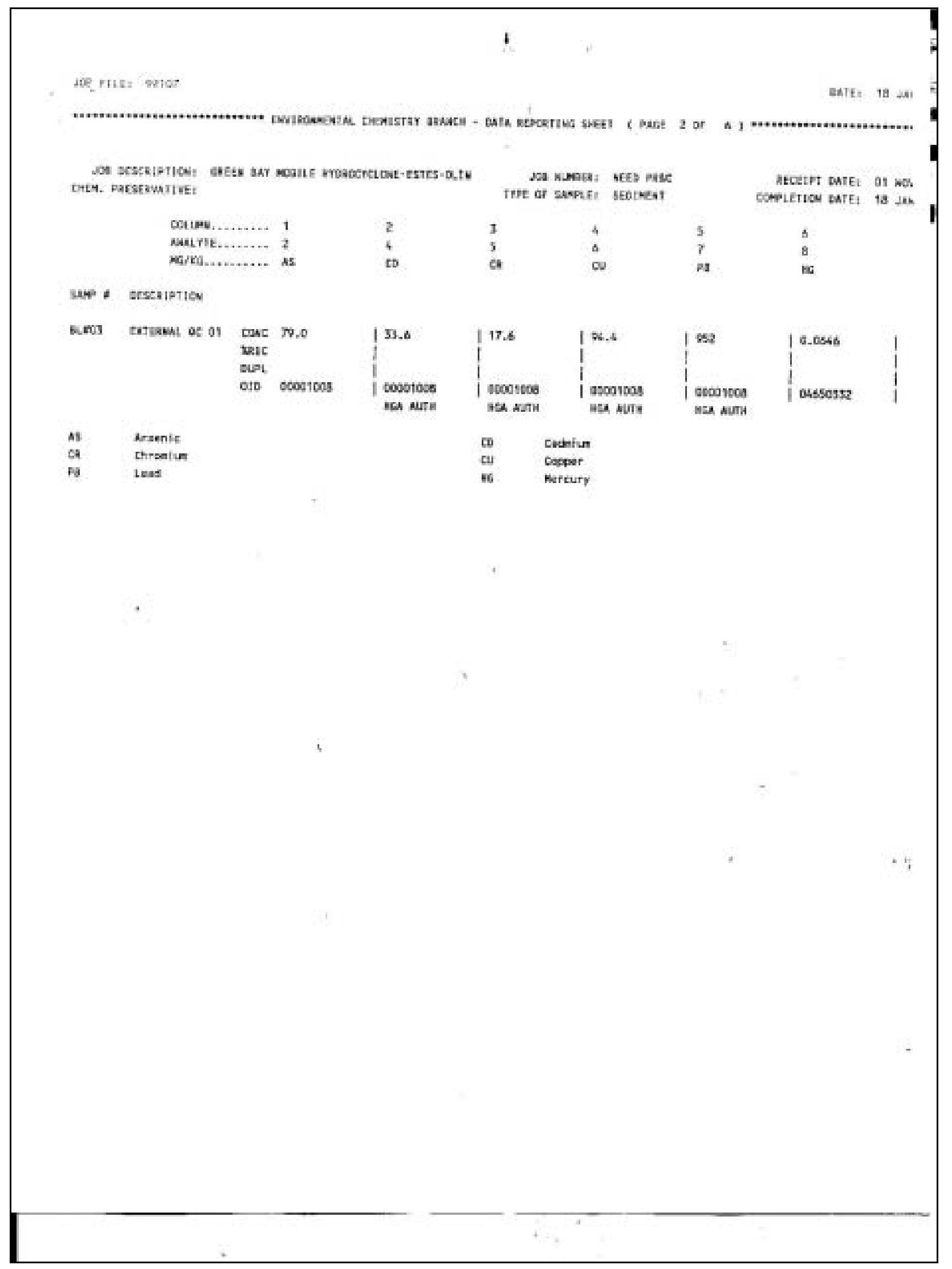




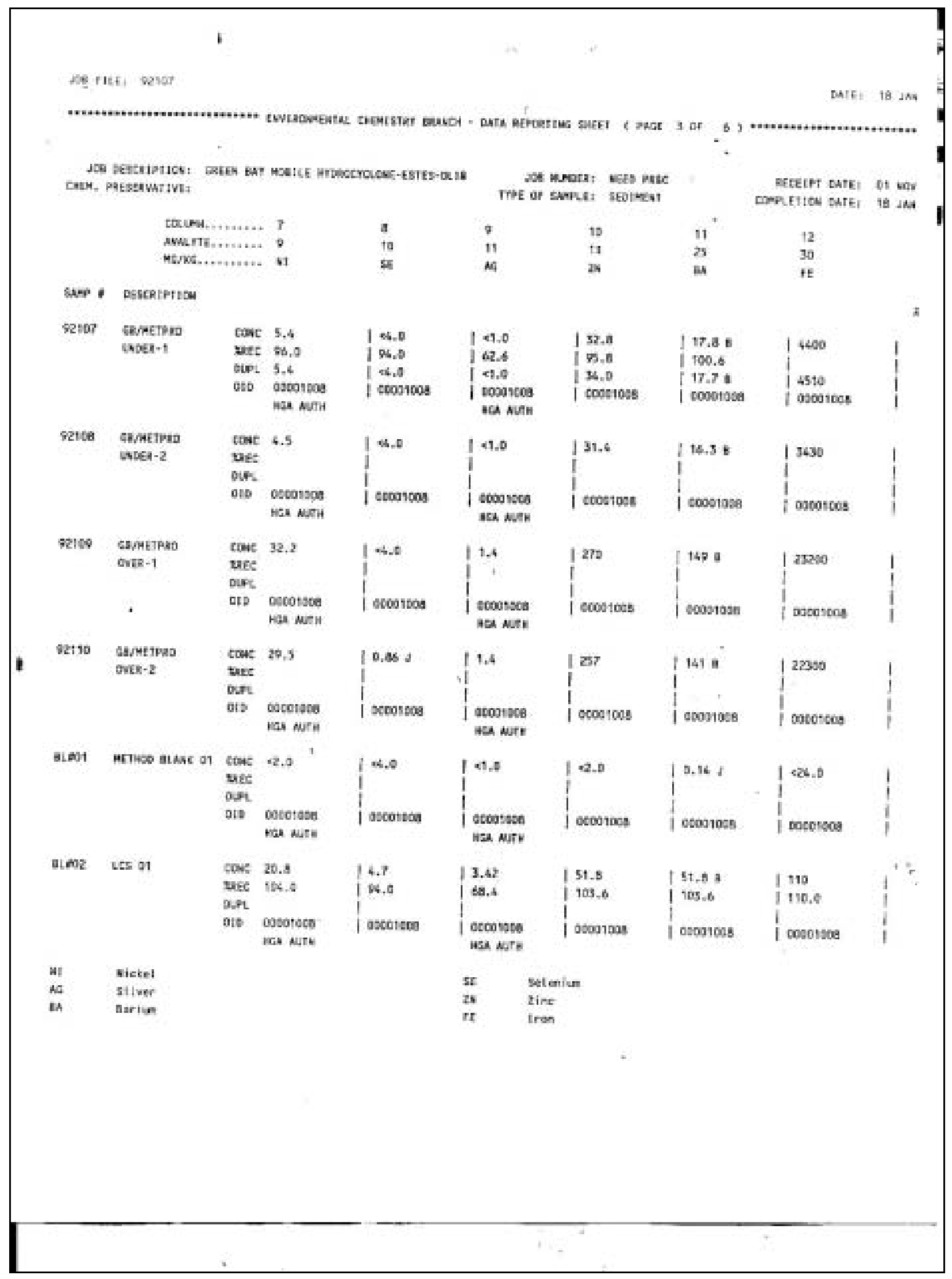




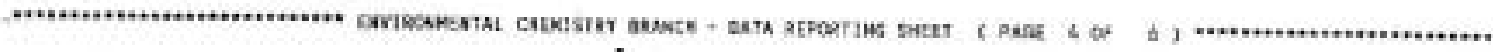
$\rightarrow$

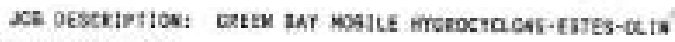
Carn, Preselwative:

Jo6 auvali: sets pasc THFe GF supt: stutwat

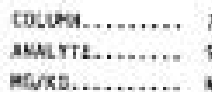

7

?

sup a Drsaiption

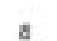

a 9

19

$\begin{array}{ll}0 & 18 \\ 11 & 13\end{array}$

a $a$
RECEIH SATE: OI MON CONEETION CATET IA ZAS

$\begin{array}{ll}10 & 11 \\ 13 & 20 \\ 2 & B A\end{array}$

$$
\begin{array}{ll}
11 & 12 \\
7 & 30 \\
7 & \text { FE }
\end{array}
$$

\begin{tabular}{|c|c|c|}
\hline $\cos c$ & 15.6 & 05,0 \\
\hline bit & & \\
\hline Dupi & & | \\
\hline Dio & $\begin{array}{l}\text { 60001008 } \\
\text { aca auts }\end{array}$ & onsc10se \\
\hline
\end{tabular}
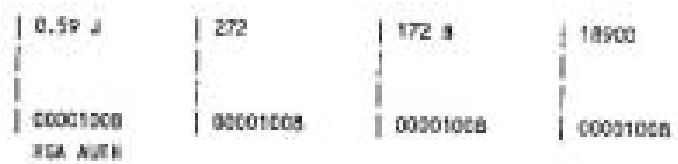

$\begin{array}{ll}\text { Wi } & \text { sickel } \\ \text { As } & \text { sitiver } \\ \text { Ba } & \text { darium }\end{array}$

$\begin{array}{ll}\text { se } & \text { Setenise } \\ w & \text { rine } \\ n & \text { irsen }\end{array}$

$+$ 


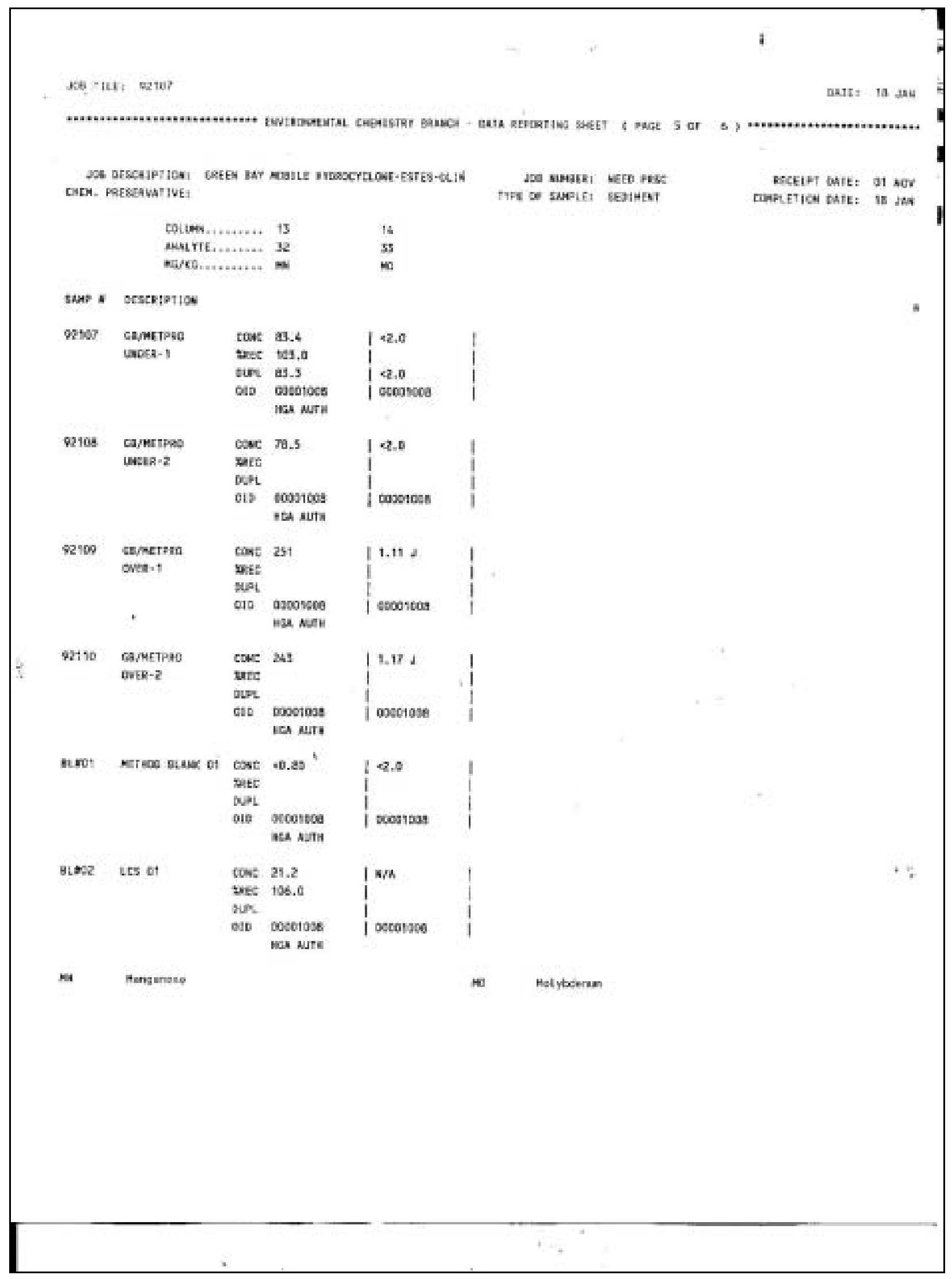




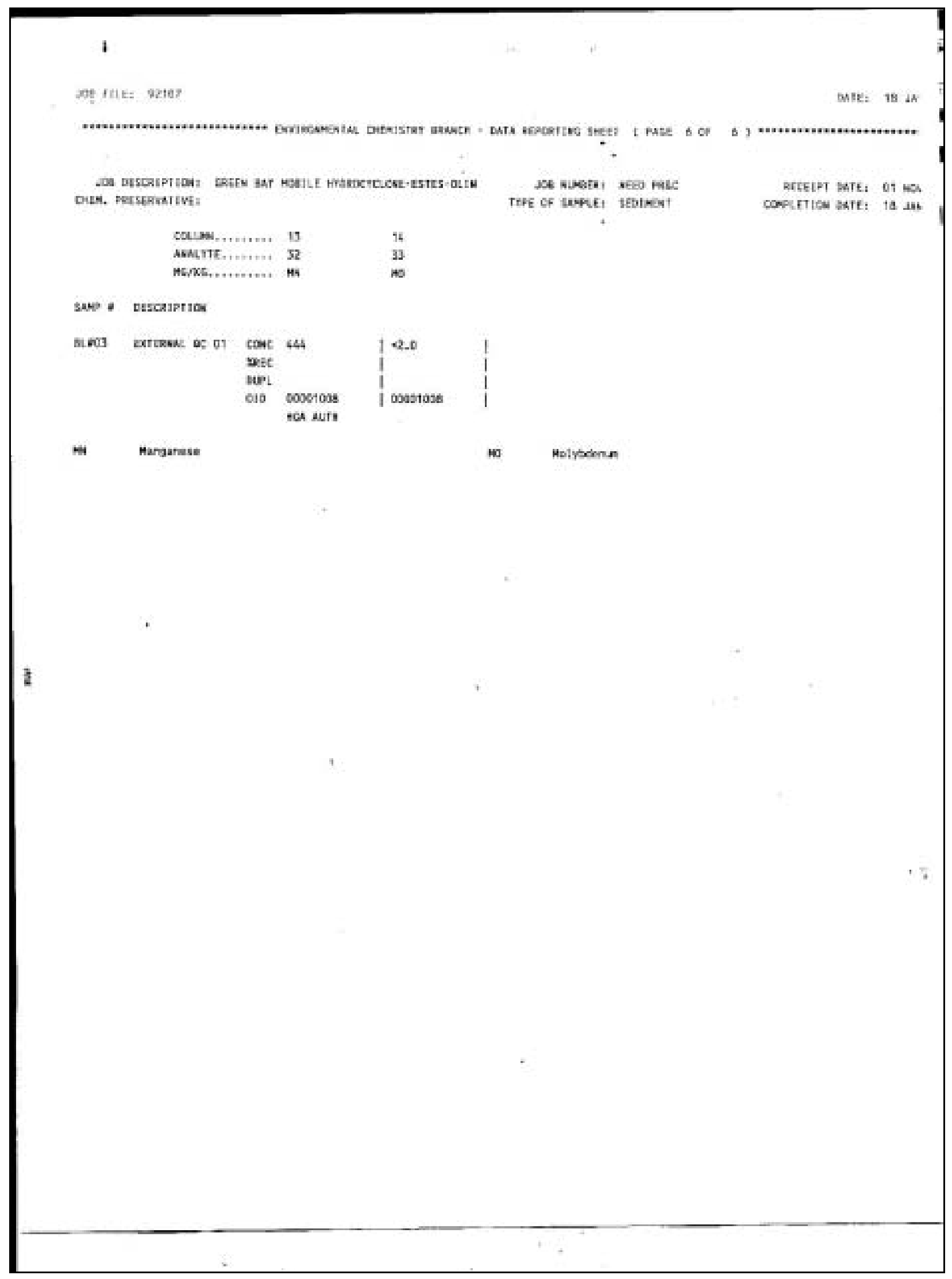




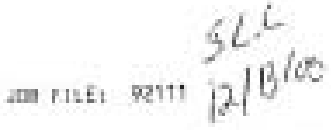

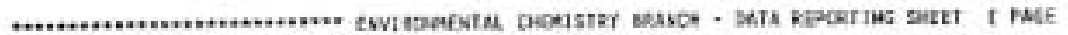

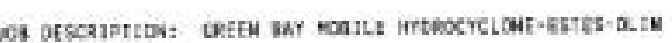
Crem. Pesesavirave

$$
\begin{aligned}
& \text { mives......... ! } 1 \\
& \text { NพALTTE........ IS } \\
& \text { pop............. FCA-1018 }
\end{aligned}
$$

\section{2}

$1 \mathrm{Je}$

1.09-1221

0anci: setb pase Irot of sueve: WArEk

5

139

วเn-1252

\section{6}

160

PCE-1242

161 rea-1260

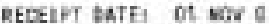
copherida bafEt 12 bet a

sava aescriptics

g211 [8/201 uste?
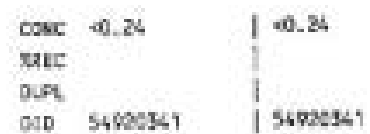

$\left\{\begin{array}{l}0.26 \\ 54900364\end{array}\right.$

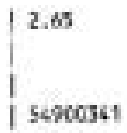

10.24

S6racs4i

92112 Ga/methas

cove 40.26

ONCR 1

serc

bur.

els 54920061

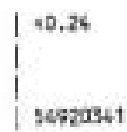

$\left\{\begin{array}{l}<0.24 \\ 5092544\end{array}\right.$

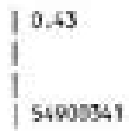

5402584

5

pca-1254

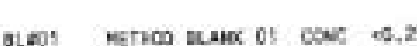

$$
\begin{aligned}
& \text { zase } \\
& \text { etpi }
\end{aligned}
$$

ola sigecst

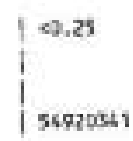

4.25

1

56920161

$=0.25$

Suvars:

$\operatorname{cosc} 2.42$

vate 9. 8

D.PL 2.30

ore stradust

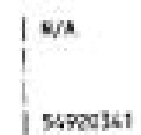

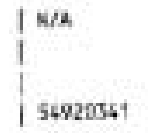

I

I socosat

$\left|\begin{array}{l}6.25 \\ \text { scoses }\end{array}\right|$

RC4-1221 NCI-1221

Neg-1262 PCs-1262

NeA-1256 PCE:1254 


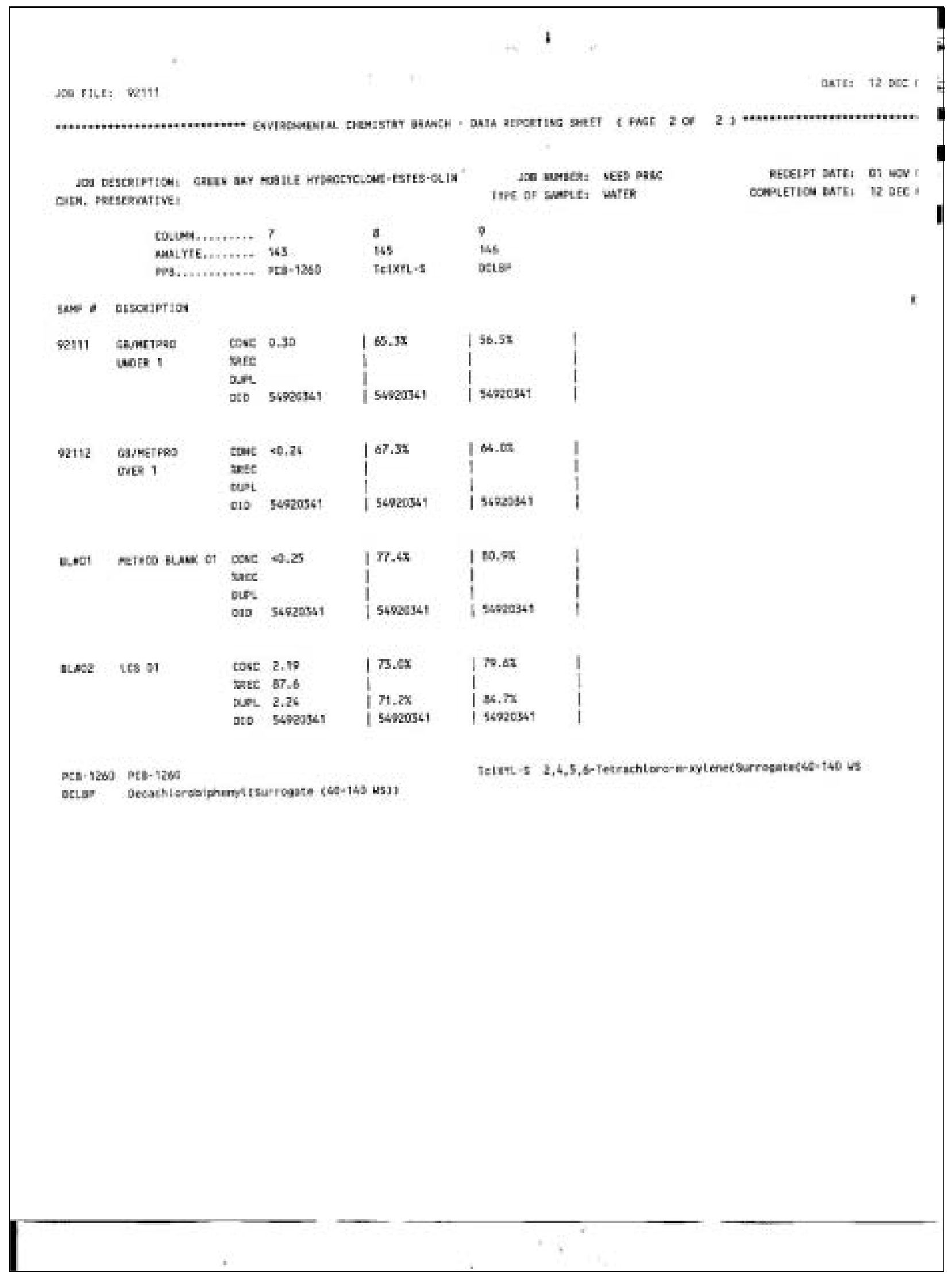




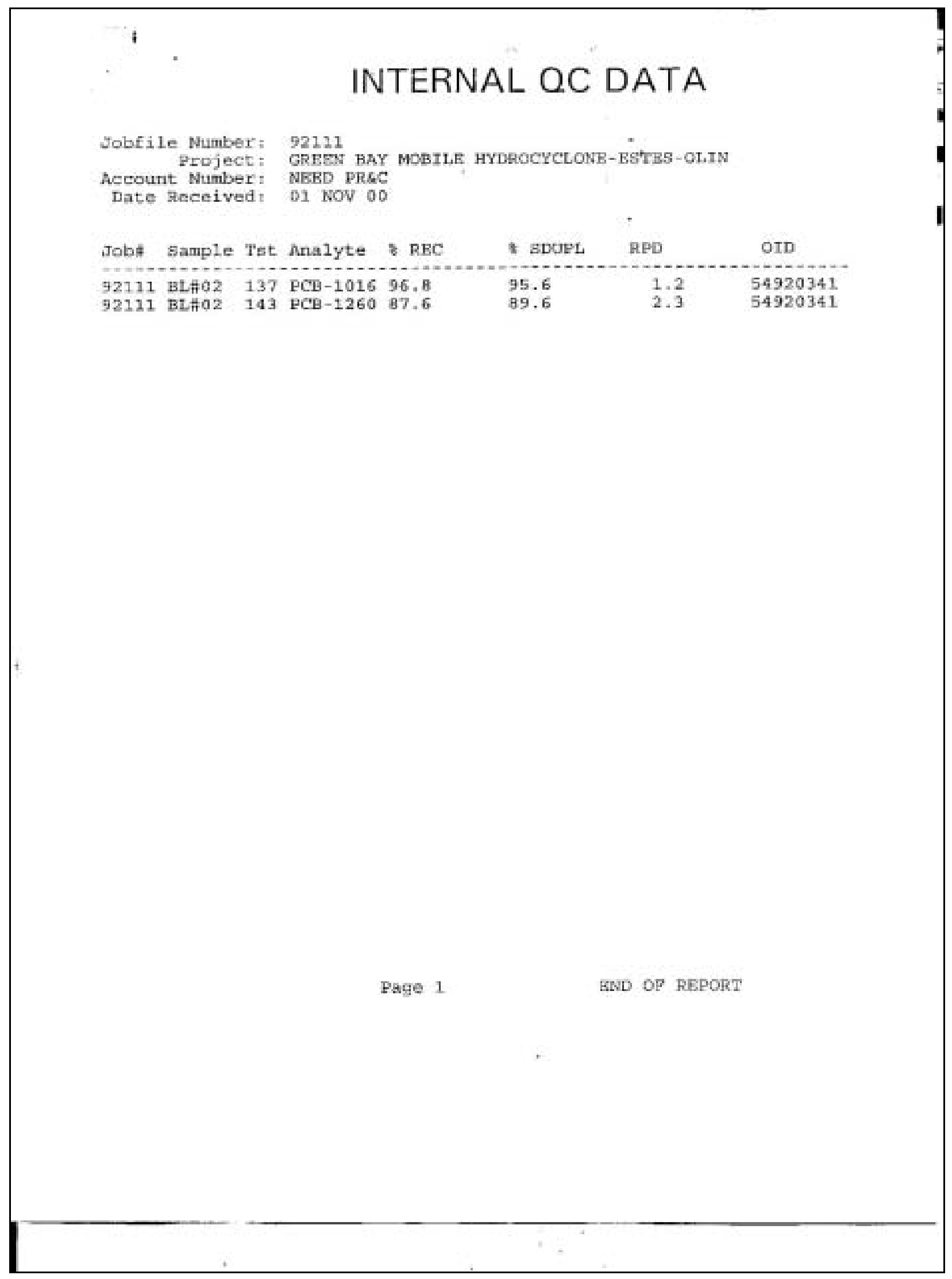




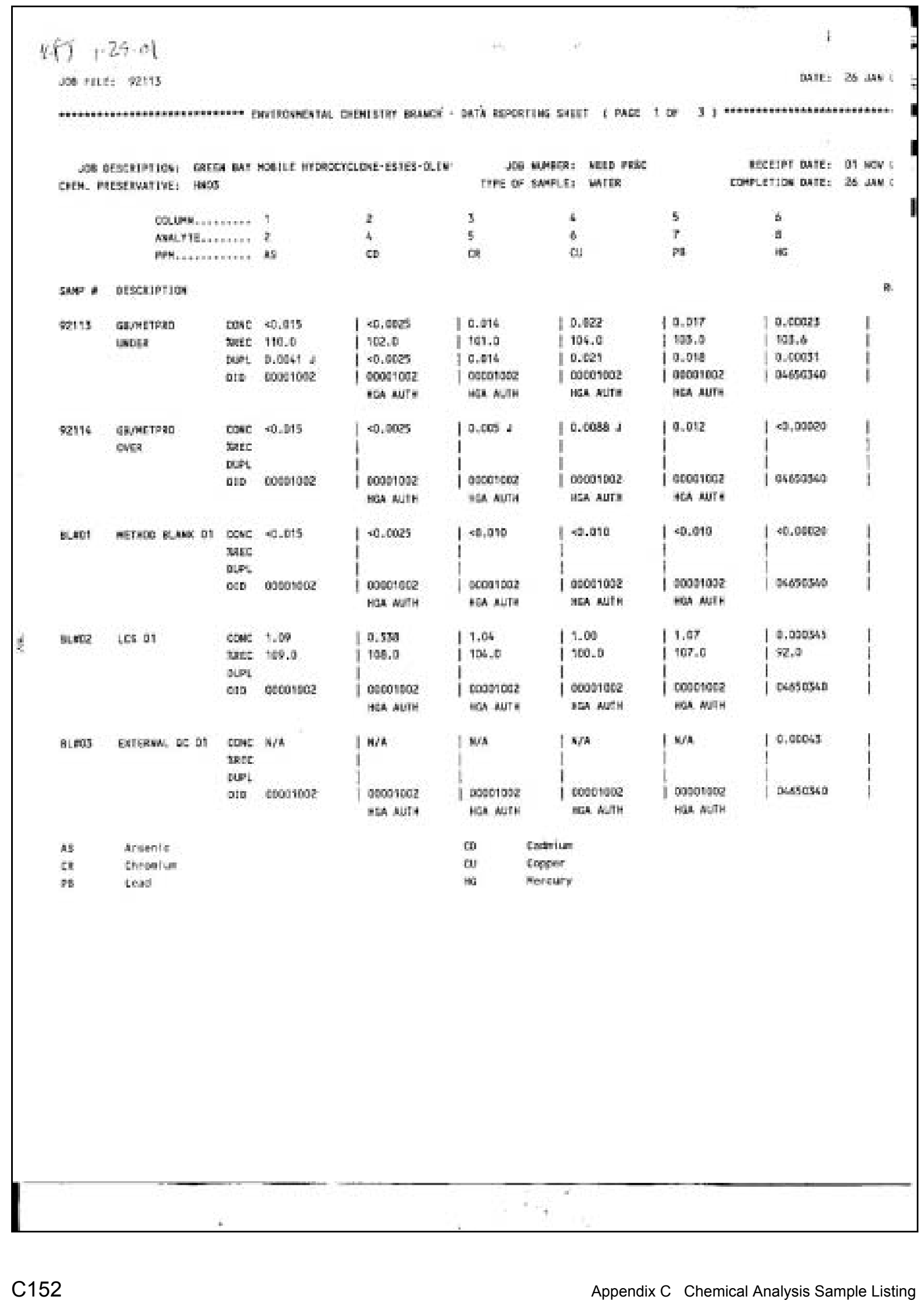




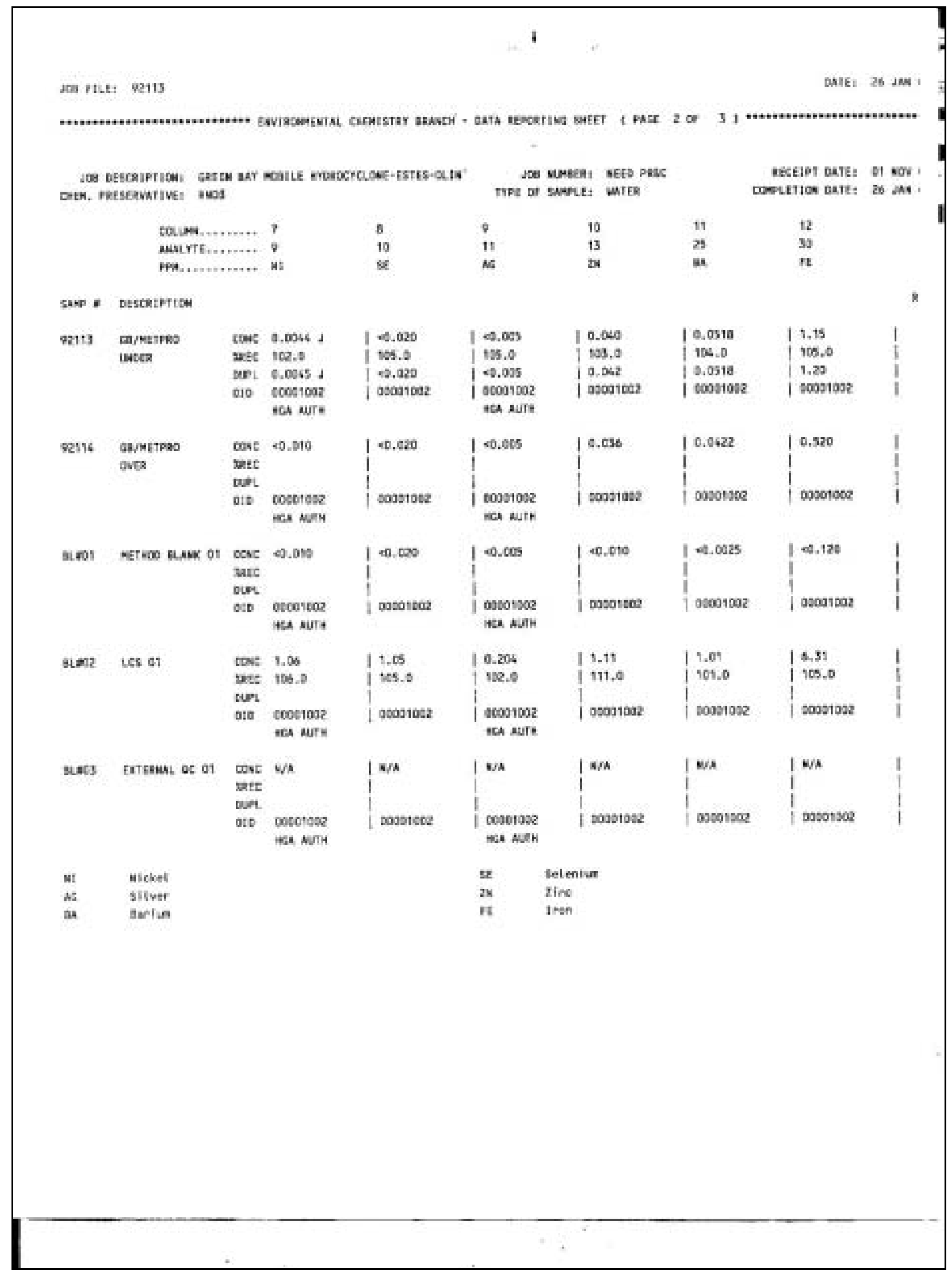




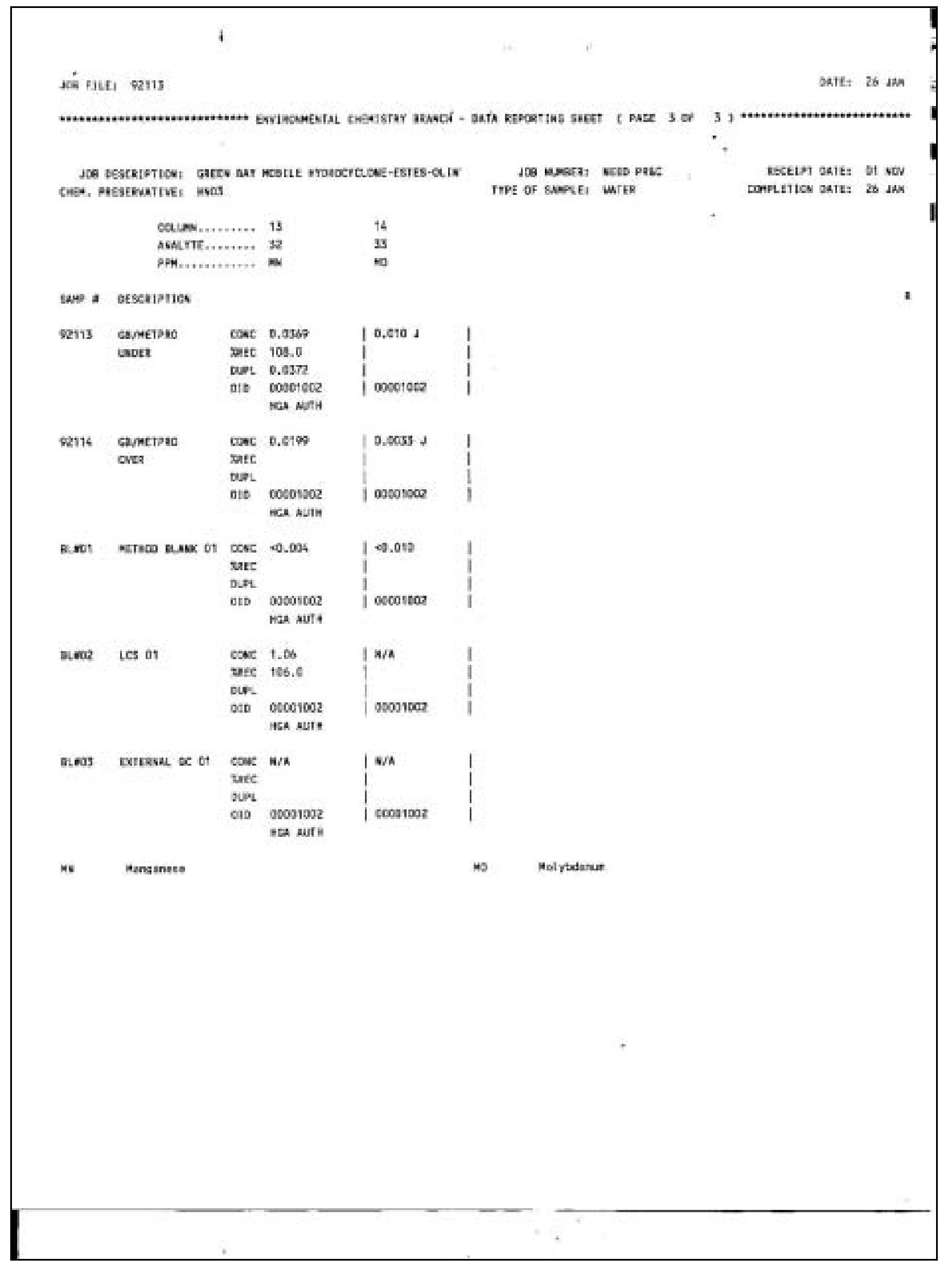


$105 \quad 2-9-01$

jos fties anas

DATE; OP FES

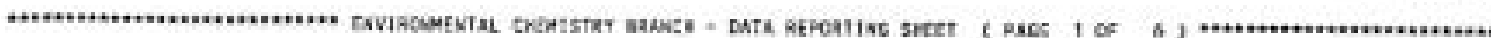

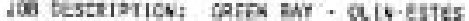
chet, DHEstantive:

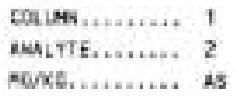

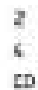

SNo * arscalapion

95010

stvo 1 seth 4

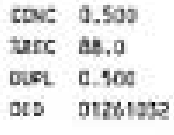

194.0

0.060

I 0t2btes2

ras wev

$45200 \quad 32002$ cent 4
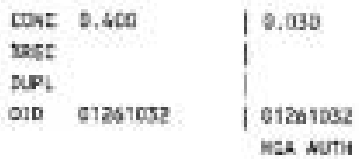

9T021 SHLT/CLAF 1

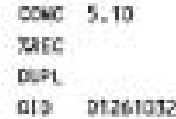

gsaze sitrous 2

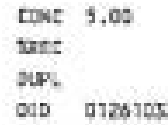

atwo

ectroe E.ask

$$
\begin{aligned}
& \text { conc } 40.200 \\
& \text { zarc } \\
& \text { Duat } \\
& \text { oro c12stesz }
\end{aligned}
$$

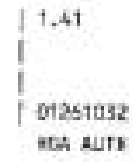
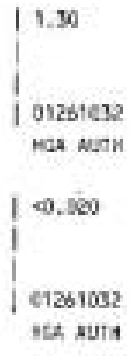

atece tes a
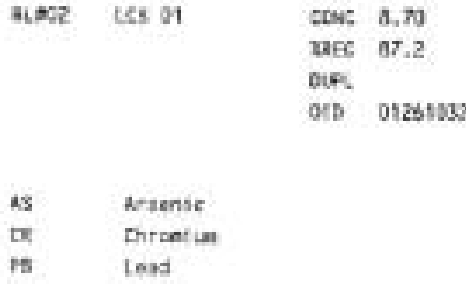

J08 vustz: tostFo-92310Ms rele or sanert: srolkont

3
5
6

4
6
0

MECEIPT DATEI 20 OET COMLETIDA DATE! 9 rta

$$
\begin{aligned}
& 8 \\
& 4 \\
& \text { HS }
\end{aligned}
$$


vos FILE: vaso

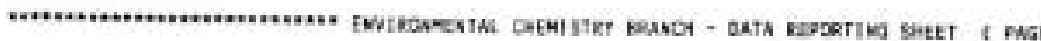

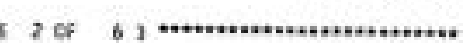

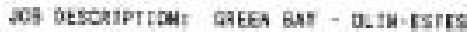
CAt*, Hesernitue!

see nimser: 005402-.25 TYPE of sAmL: STOMERT

RICEIPT BAFE: 20 DTC A

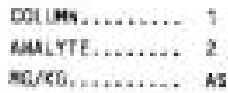

2
4

5

6

sten * Descalptios

buacs

trikake ac of cowc 43,5
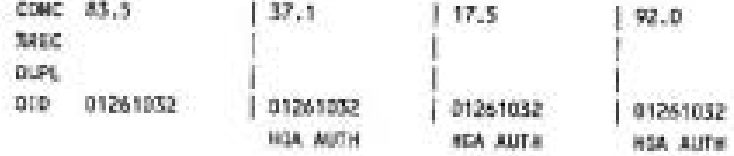

5
7
15

6

in copieticy bart: E rre

6
6
60

AS Arsenic

\begin{tabular}{|c|c|}
\hline I 1180 & 0.0537 \\
\hline & I \\
\hline & 1 \\
\hline $\begin{array}{l}21251032 \\
\text { 4c4 euts }\end{array}$ & | Desstors \\
\hline
\end{tabular}

pa leas

co Caditus
til Capoer
to

జ 
sal stie: 8900

EATE; OO FEA I

$$
+
$$

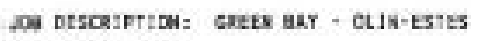
CAEN, PRTSLRWATLVE:

$$
\begin{aligned}
& \text { cD.una......... } \\
& \text { suล } \\
& \text { Asarke........... vi }
\end{aligned}
$$

บ1
SAF * IESERIPTIOA

951

LEN 1 ceU 4

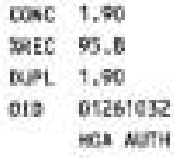

93azo

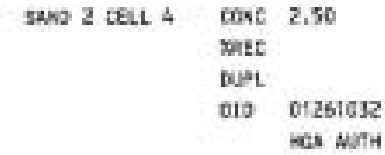

Q3e21

sitt/cLar 1

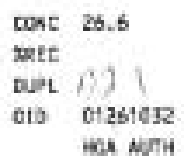

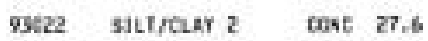

bete

bUP

ois 0125tese

an NOTH

Euot meinco suas of tôse क0, 108

wete

DUil.

01901261012

nea ANH

E.see tes ot

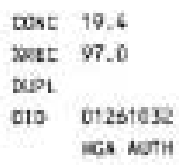

Ni Niekat

49 silver

es karlua

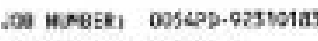
ITPE OF SUR.EI SEBIHENT

8 8

to 21

st
10

13

ar
RECriot PATE: 20 beC I

\begin{tabular}{|c|c|}
\hline 4,200 & 10.200 \\
\hline 07.2 & | 95.8 \\
\hline 40.200 & 10.200 \\
\hline 01261092 & 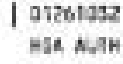 \\
\hline$\infty .204$ & $\sum_{1}^{0,300}$ \\
\hline 05261032 & $\begin{array}{l}\text { | 01261as? } \\
\text { H:2 N.AH }\end{array}$ \\
\hline
\end{tabular}
DONEETICN EATE! 9 FEA !

12

15.2
47,0
15.5

| 5.30

147.7

117.0

15.50

otzstege | otzstcas

1 49.7

to:2atos?

Maล ALT

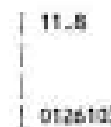

13.50

I

otzstase

( ot2stas

| 40.8

I ot $25+6 x$ พละ AUTh
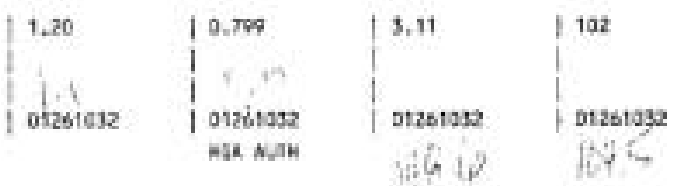

I sas.

$1435=$

ot2stcen | Iat auta

\section{6}

$2 x$

$\begin{cases}1.00 & 1,00 \\ 05261612 & \text { 0126108 }\end{cases}$

107

1

T

\begin{tabular}{|c|c|}
\hline \multirow[t]{2}{*}{9.208} & $\mid=2,100$ \\
\hline & 1 \\
\hline & 1 \\
\hline 01261632 & $\begin{array}{r}\text { | } 07281082 \\
=52, \mathrm{N.TM}\end{array}$ \\
\hline
\end{tabular}

|

ot2stexe

ka muth

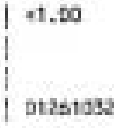

| 0.100

1.0 .108

\begin{tabular}{|c|c|}
\hline 4.20 & 14.50 \\
\hline 65.6 & 192.6 \\
\hline $0+26+172$ & I \\
\hline
\end{tabular}

1

atabtom Ita AJTH
$166-8$
(6).?
।

B. 8

Drostase

| 19.2

1 ต. 0

I

| 0125702 HoN NगTH 


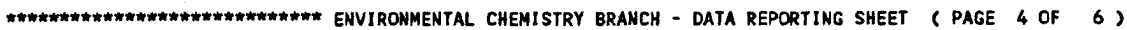

JOB DESCRIPTION: GREEN BAY - OLIN-ESTES CHEM. PRESERVATIVE:

COLUMH.........
ANALYTE........
MG/KG.........

SAMP \# DESCRIPTION

BL:\#03 EXTERNAL OC 01
8
10
SE

$\left\{\begin{array}{l}1.40 \\ 01261032\end{array}\right.$

JOB NLMBER: 0054PD-92310183 TYPE OF SAMPLE: SEDIMENT

$\begin{array}{lll}9 & 10 & 11 \\ 11 & 13 & 25 \\ \text { AG } & 2 \mathrm{~N} & \text { BA }\end{array}$

1329

1

01261032

HGA AUTH
RECEIPT DATE: 20 DEC 00 COAPLETION DATE: 9 FEB 01

$\begin{array}{ll}11 & 12 \\ 25 & 32 \\ B A & \text { MN }\end{array}$

N1 Nickel

AG Silver

BA Barium
OID 01261032

HGA AUTH

$\begin{array}{ll}\text { SE } & \text { Selenium } \\ \text { ZN } & \text { Zinc } \\ \text { MII } & \text { Mangenese }\end{array}$

MN Manganese
ROW

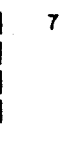




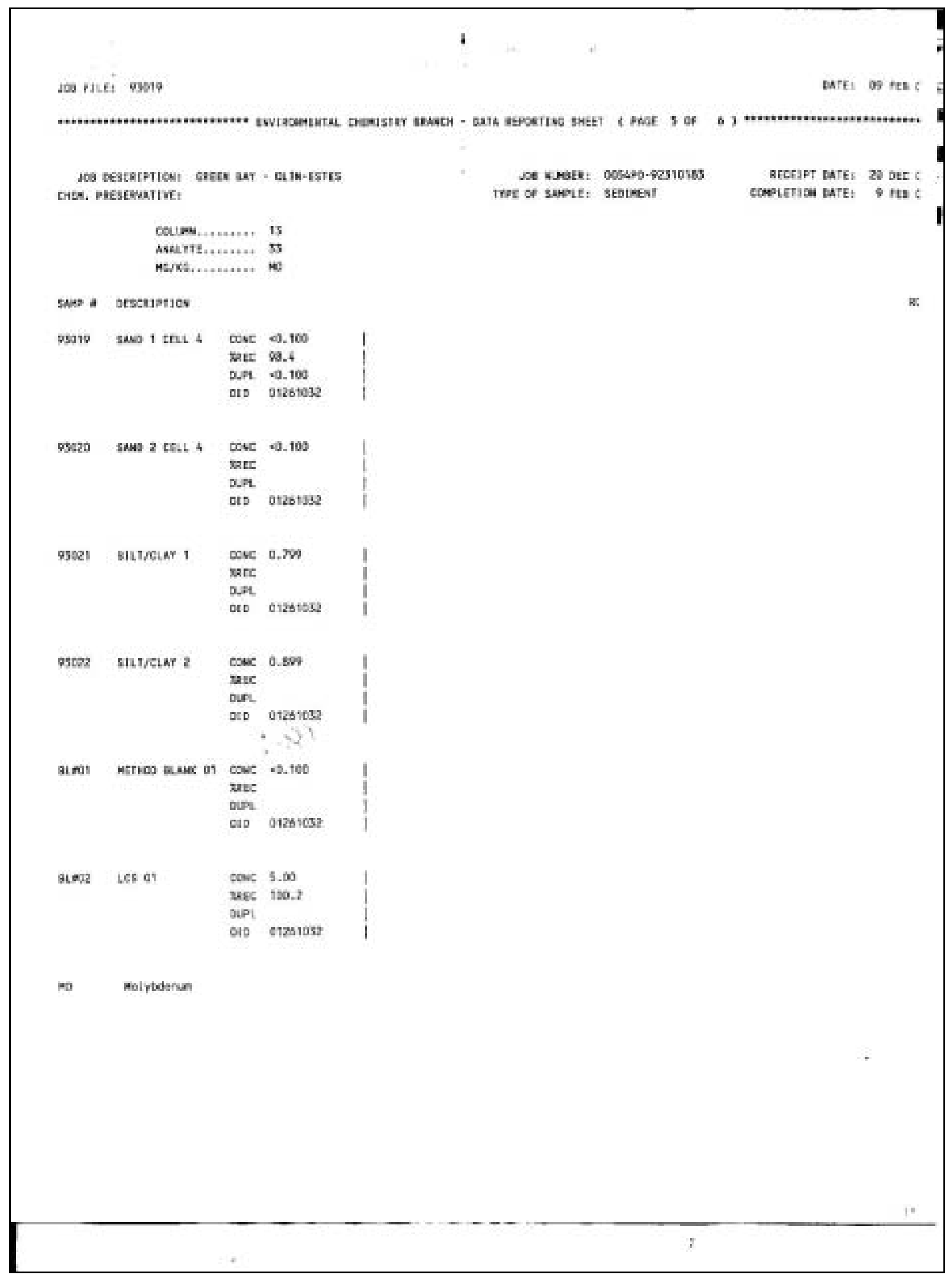




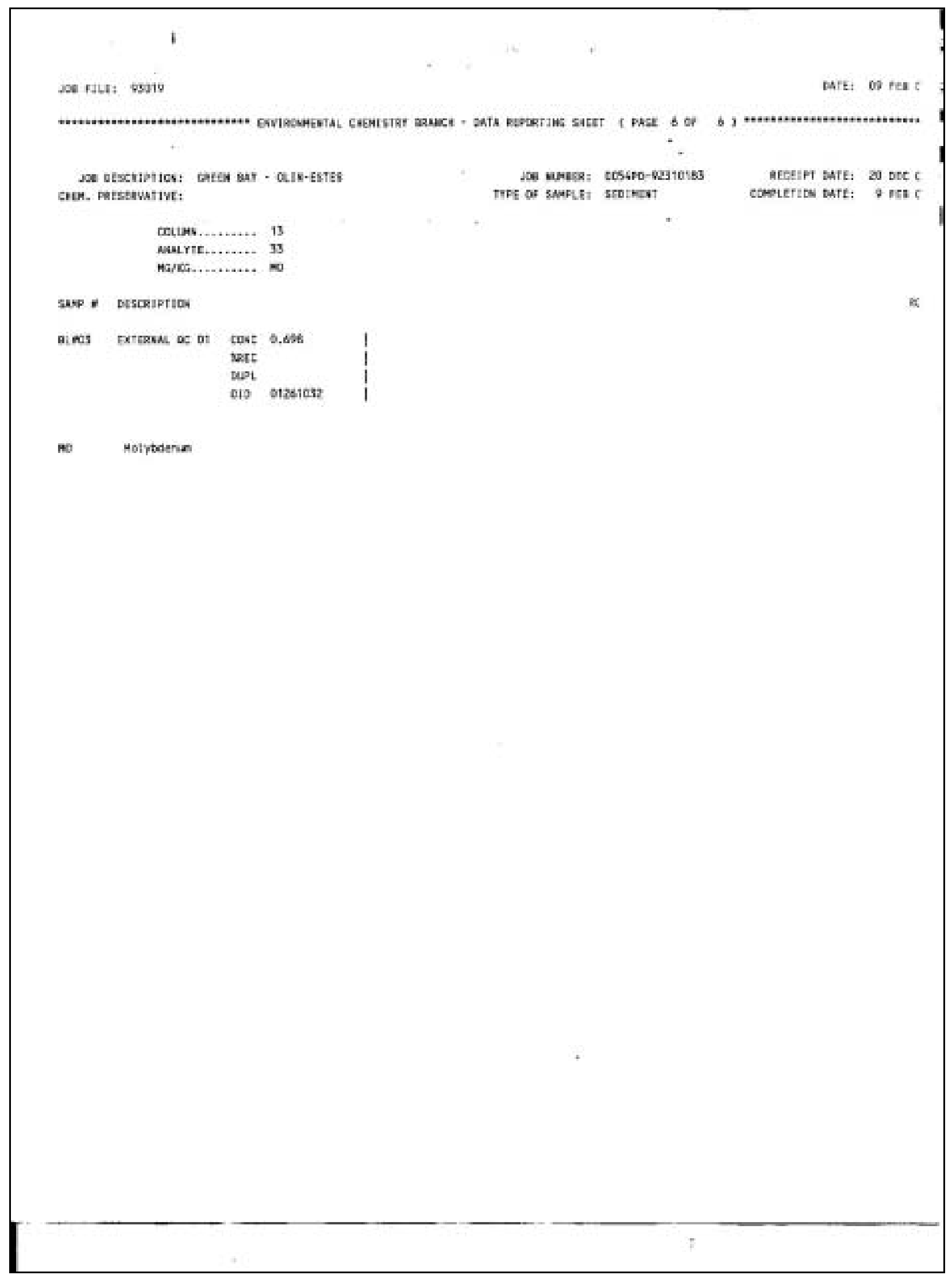


Wit $1-2,20$

vos PLLE: gTazs

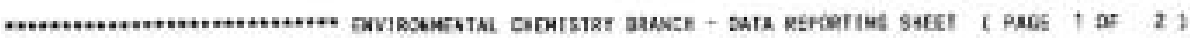
$\because$

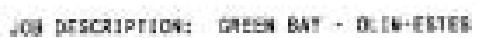
CaF*, pesssanarivt;

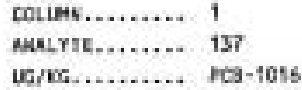

7 I19 7เ8-1221

$$
\text { doe vureets cos6pt-923:61as }
$$
TYPT af SNTLE: SESHAET

365

$139 \quad 145 \quad 141$

PCs: 1232 nectipt DAIE: 25 aEC । COPLETIOS OATEI 25 JAM

sit PEs-124s

142

FC3-1256

saw * bescetptida

qunes

\begin{tabular}{|c|c|}
\hline sto.3 & $\mid=10.3$ \\
\hline 62.8 & 1 \\
\hline sustcis? & | 96921012 \\
\hline
\end{tabular}

$<10.3$
$5462 t 512$

| 34

i

$\sin 210$

$$
3 y^{\prime}
$$

geas

\begin{tabular}{|c|c|c|}
\hline $\operatorname{cose}$ & +12.3 & $1+10,3$ \\
\hline getc & & | \\
\hline DUPL & & \\
\hline al? & S421912 & 96921012 \\
\hline
\end{tabular}

sais 2 cEL 4

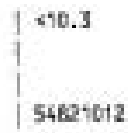

$\mid \begin{aligned} & 523 \\ & 54525012\end{aligned}$

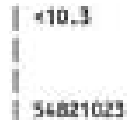

| 40.3

$5462+012$

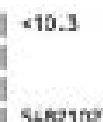

| 45.3 susta12

9gazs stLt/nar 1 cose 58.1

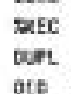

ReEc

ote S42ta12

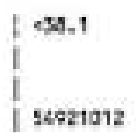

| 3a.1

$\left.\right|_{\text {S Ste210t2 }} ^{\text {3a.1 }}$
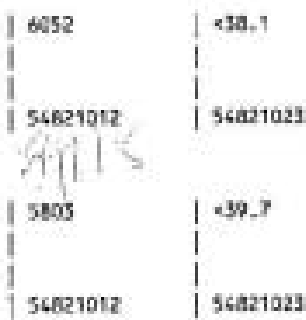

105,1

1 she2t212

99025 stLf/CLAT 2 cose 39,7

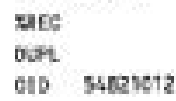

$\mid-30.7$
I sosterz
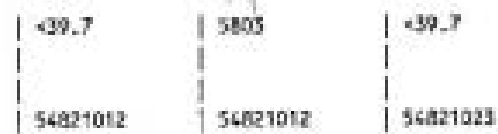

$1 \cdot 39.7$

54824012
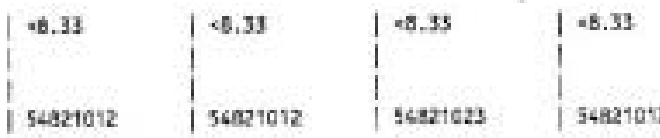

B.tibe ics ot

\begin{tabular}{ll|l} 
cow 0.75 & $\mathrm{~N} / \mathrm{h}$ \\
ate 97.2 & \\
bupt & & \\
o10 54a21012 & 54921012
\end{tabular}
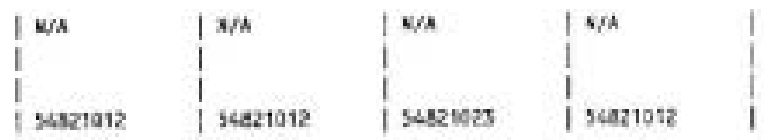

PeA-1916 PCD-1014

PCy-1221 ac8-1221

Pts-1232 PCB-1252

res-1242 acs-1242

1ca-1256-158-1256 


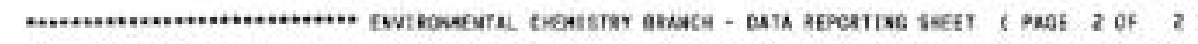
$\cdot$

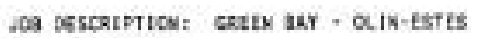
CAEH, HESTRETIVE:

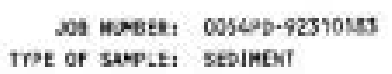




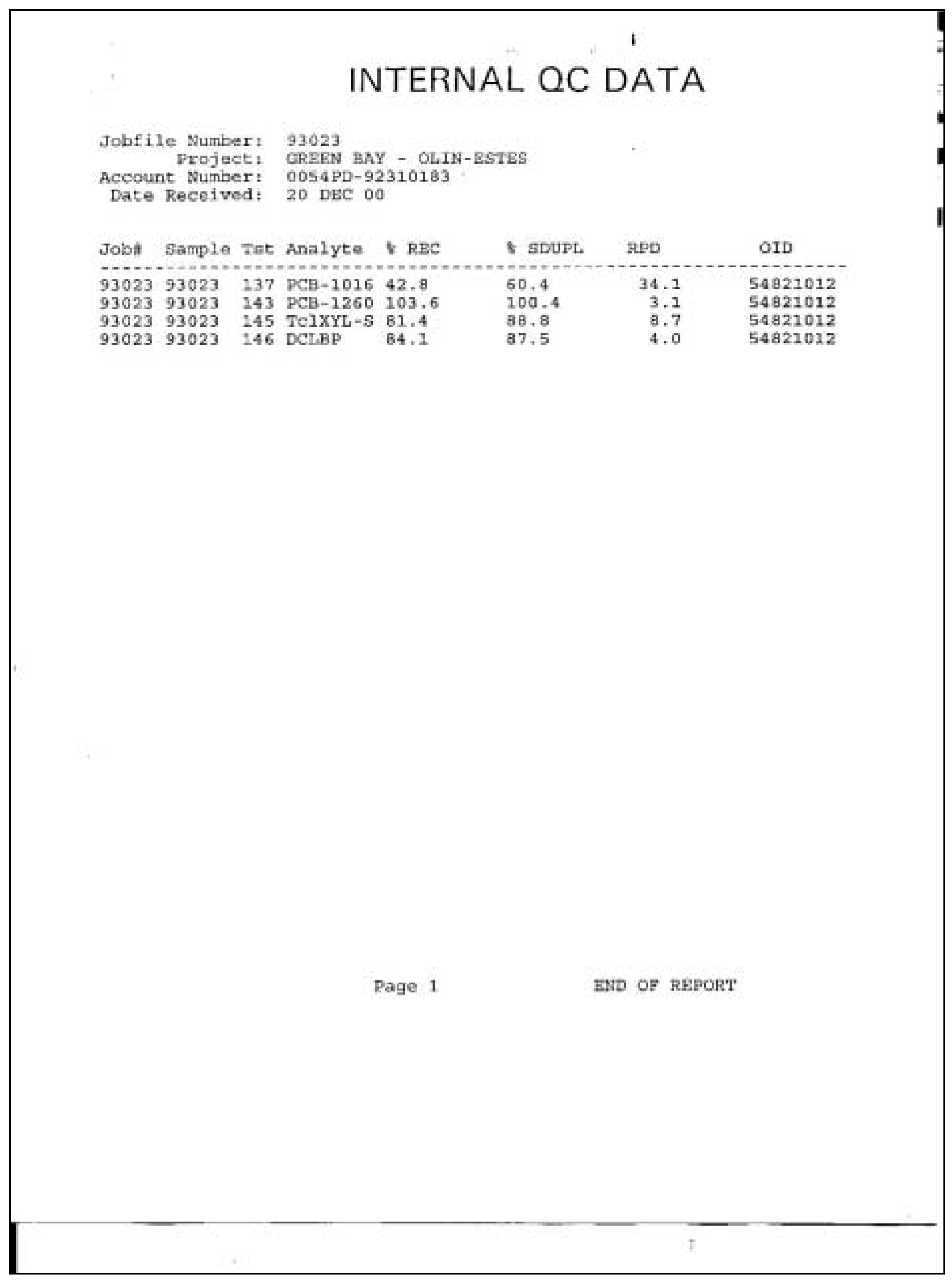




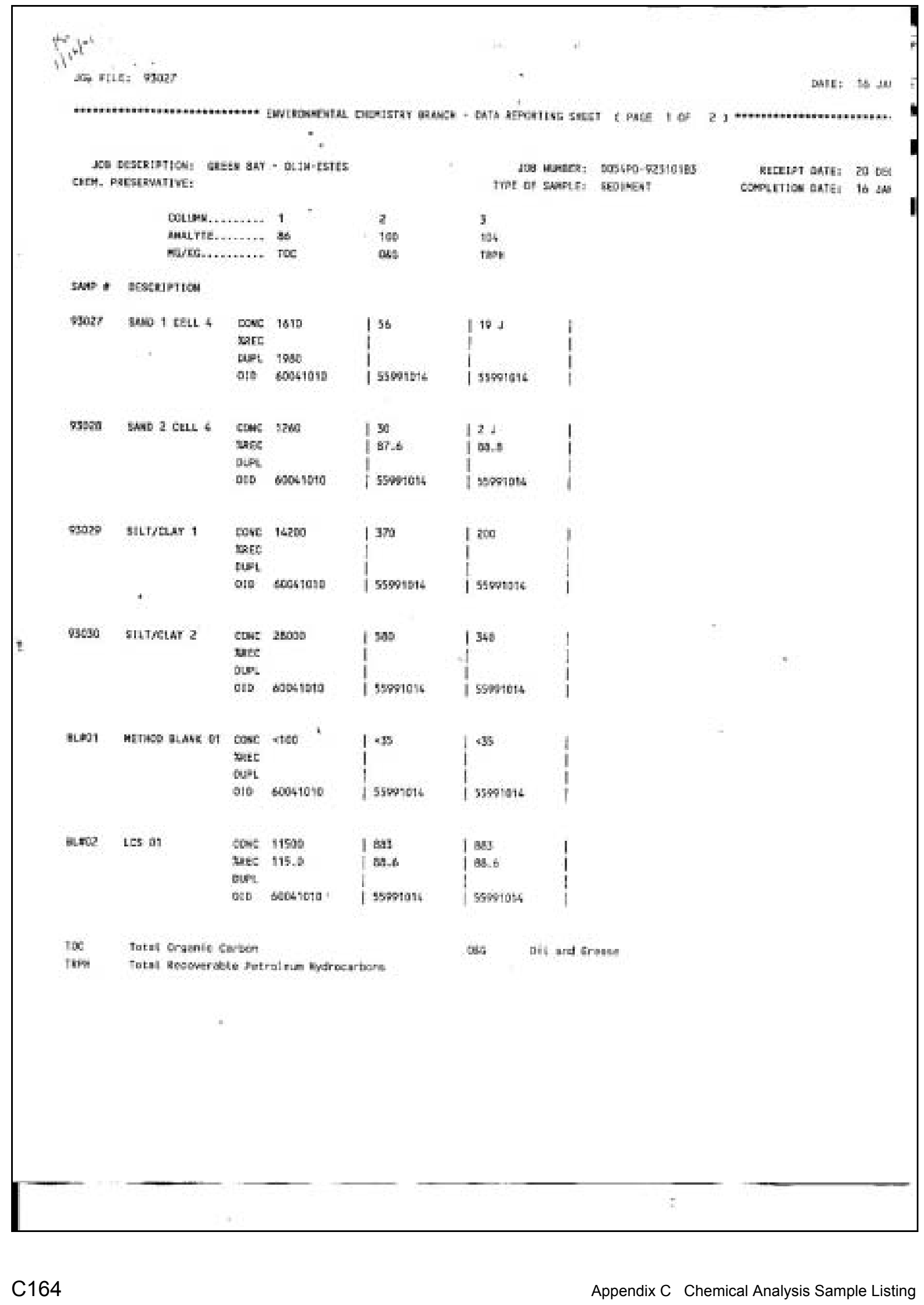


183 ficti 3998

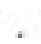

oud oul and tresse 


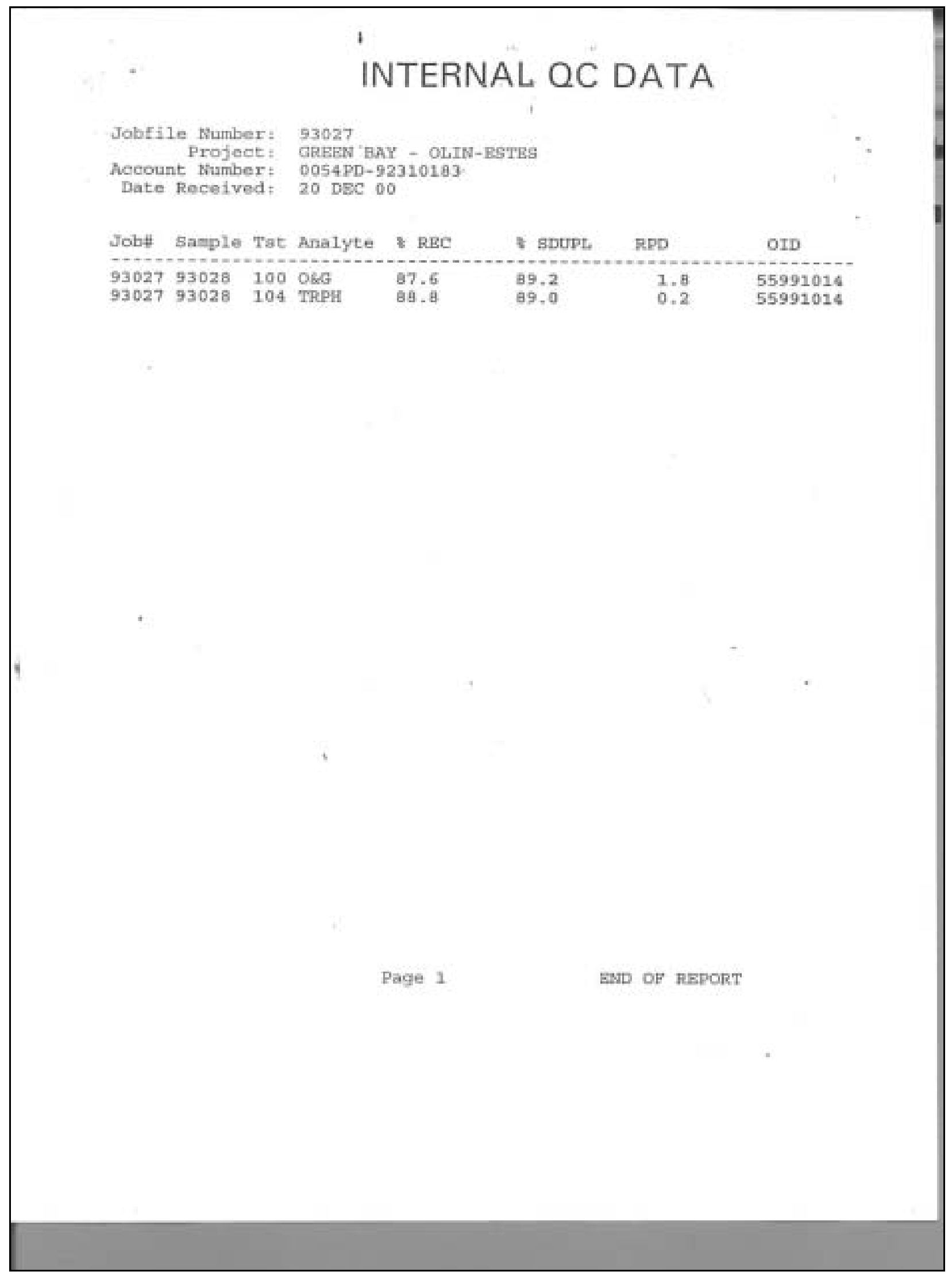




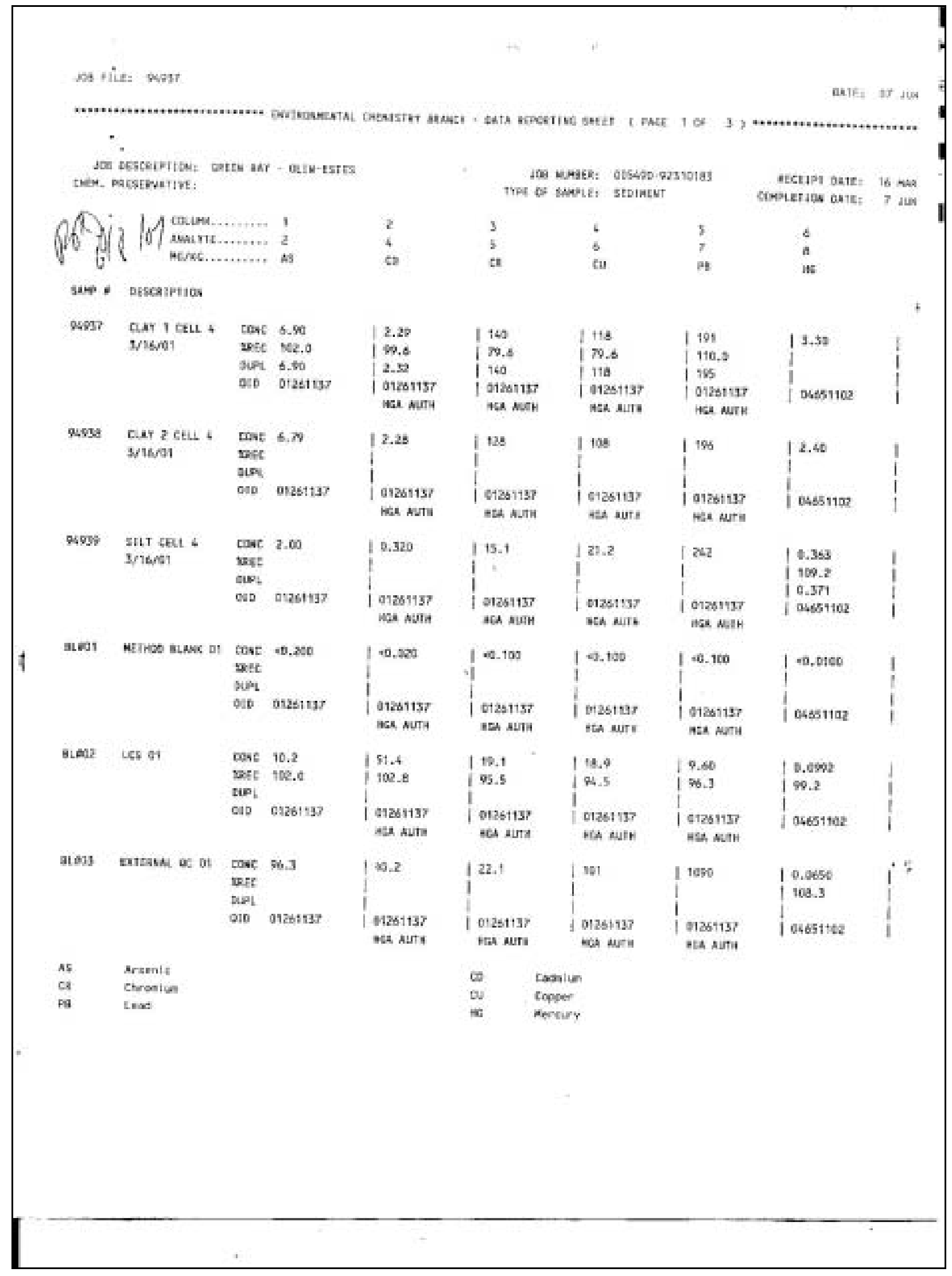




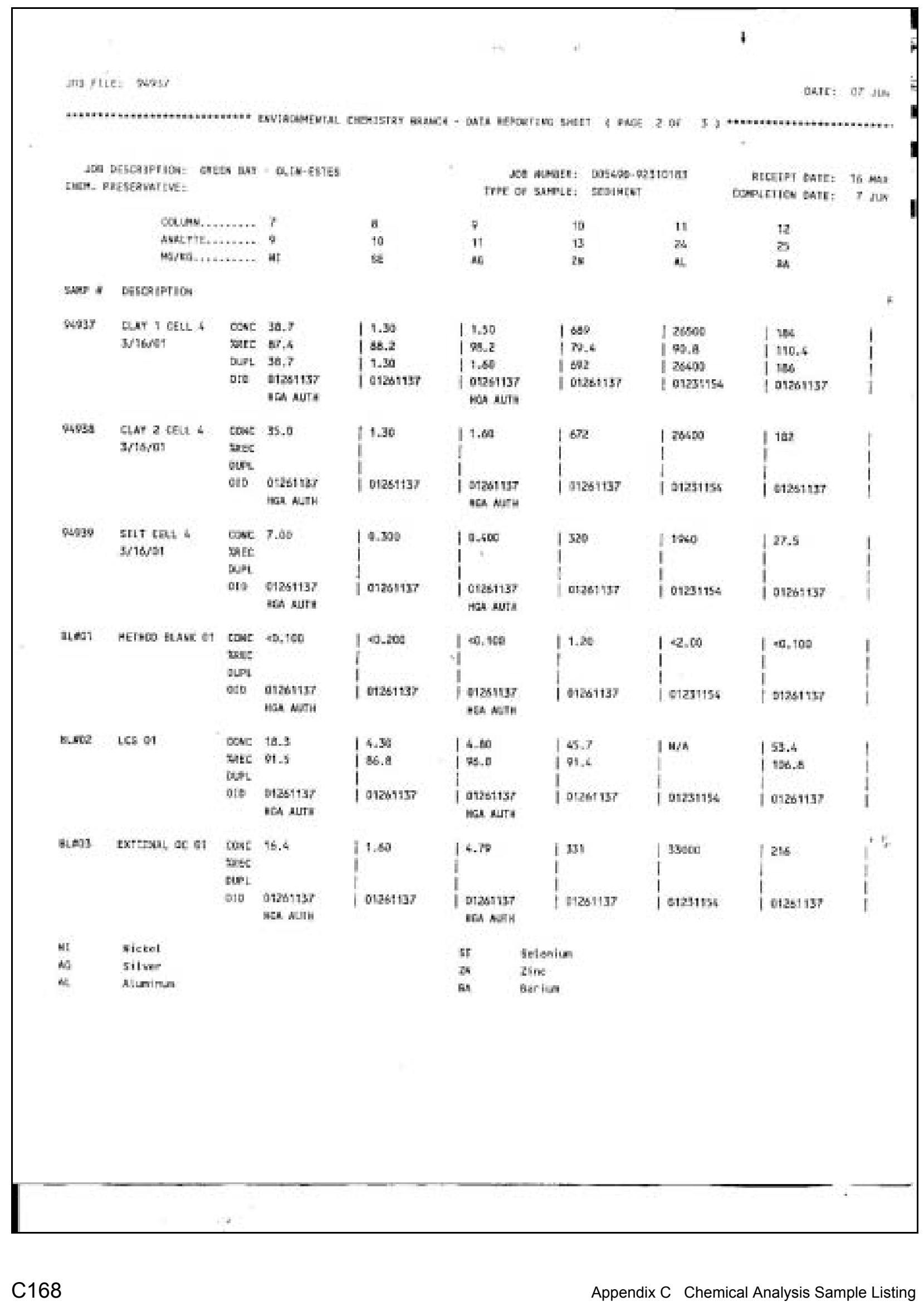




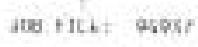

Dath, of ats

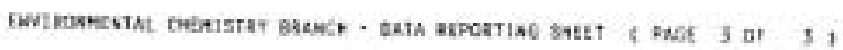

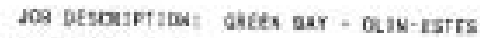

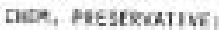

$$
\begin{aligned}
& \text { DCi ias ........... } 19 \\
& \text { asui YTE, ....... \$o } \\
& \text { NC/kSB,.......... }
\end{aligned}
$$

savo t etscriptios

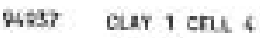
3osibet

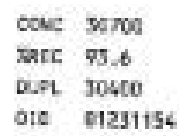

1390

190.6

I 335

I $0120173 \mathrm{~T}$

nat ALTI

Mesa Gar $2 \mathrm{cru}$ s 3/1601

cove 90500
tate
bun
oid 51231156

1312

I

i

1 อ126เ19?

$$
\text { mas mats }
$$

94998

$$
\begin{aligned}
& \text { SrLt ctut } 4 \\
& \text { Jitovi }
\end{aligned}
$$

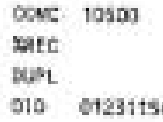

1376

I

I 0ะzotyม va mir:

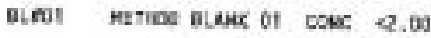

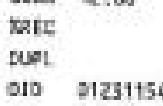

$\left\{\begin{array}{l}60.160 \\ 00251137 \\ \text { tos nurk }\end{array}\right.$

ELver LCS 01

$$
\begin{aligned}
& \text { cose tre } \\
& \text { Xatc } 112.0 \\
& \text { Het } \\
& \text { क) } 21231156
\end{aligned}
$$

1 18.7

193,5

I

0.26513

nat wath

SLDOS EXIERAL oC DT

$$
\begin{aligned}
& \text { cove } 42100 \\
& \text { Whet } \\
& \text { but } \\
& \text { ote c1231154 }
\end{aligned}
$$

1 305

I

1

f 01261137

ans Nurk

Fe Iron

4) Mel Yodirnom

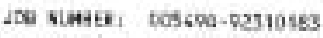
Tres of sapif: sminis?

15
13
4

w.
Eecaspr bart: 16 mas Cons.rtica part: 7 dus
| 1.00

I 116.4

| 1.60

| 0525113 ?

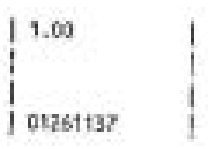

$\left\{\begin{array}{l|}0,500 \\ \mid \\ \text { 0025:158 }\end{array}\right.$
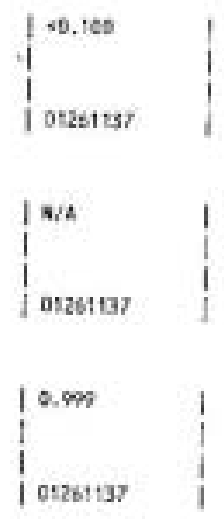

M. Ainganese 


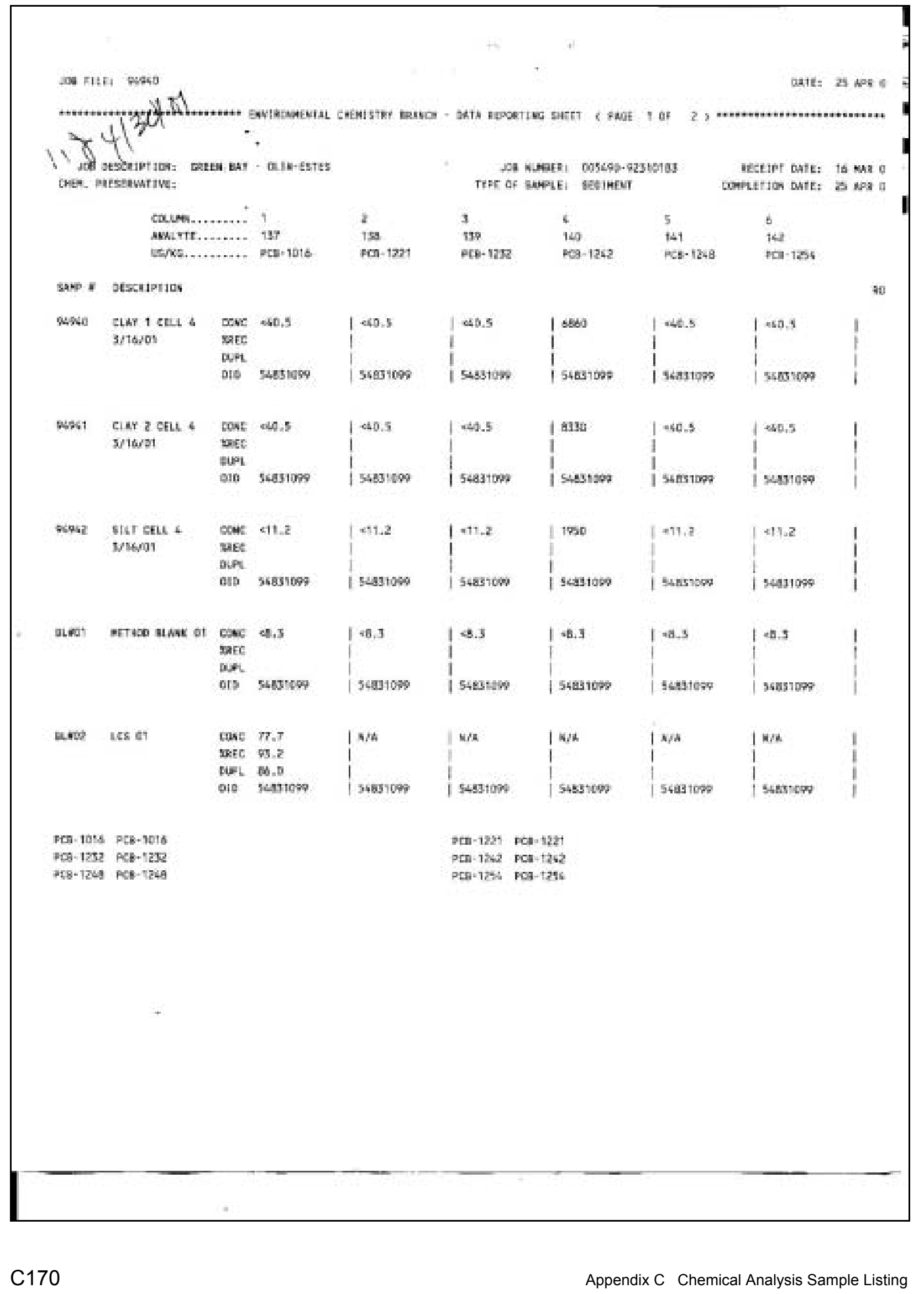




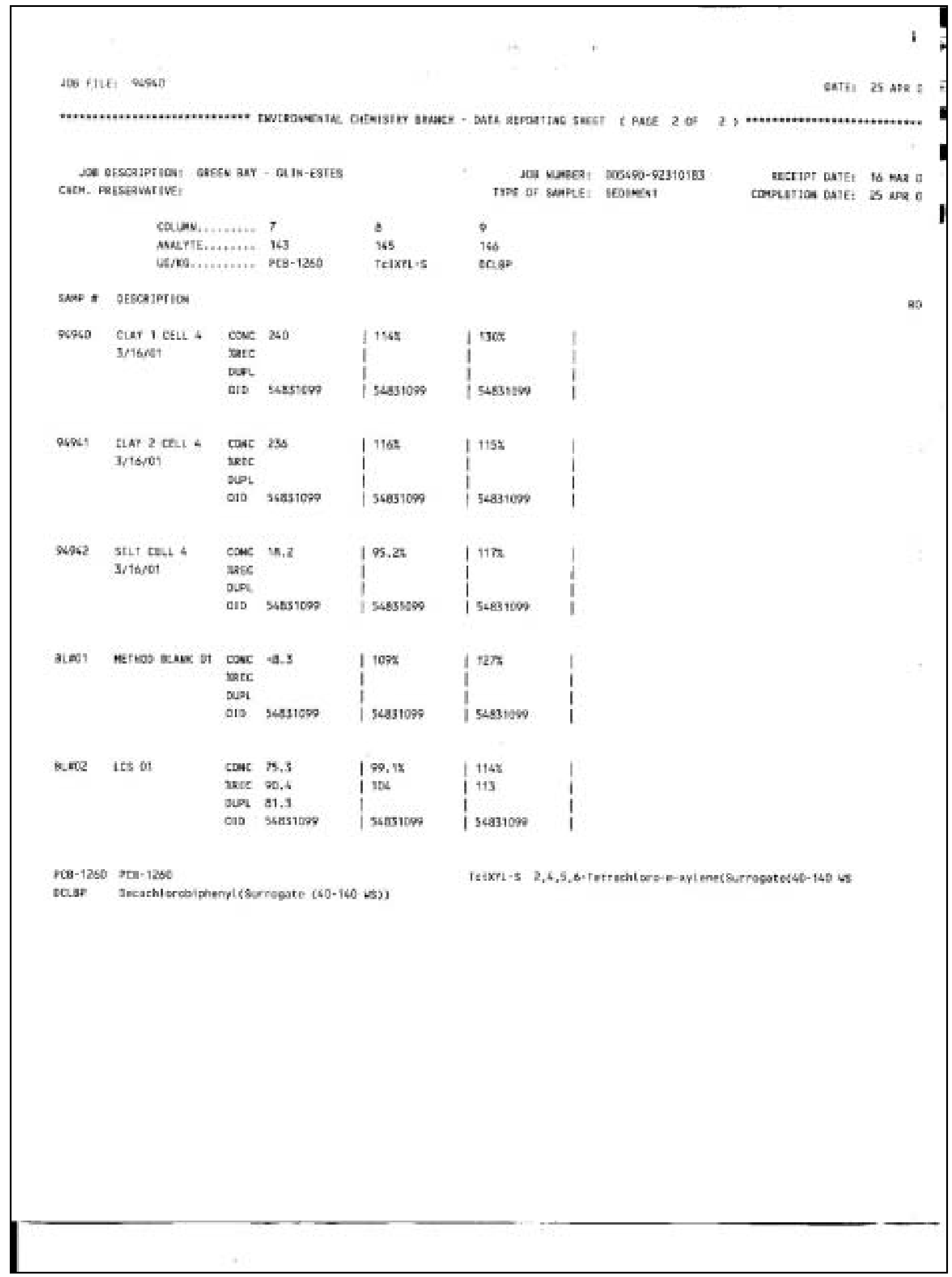




\section{1 INTERNAL QC DATA}

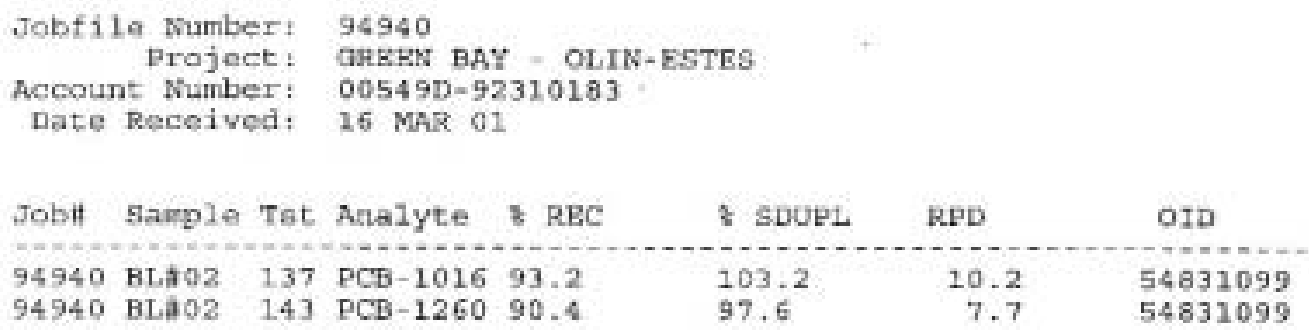




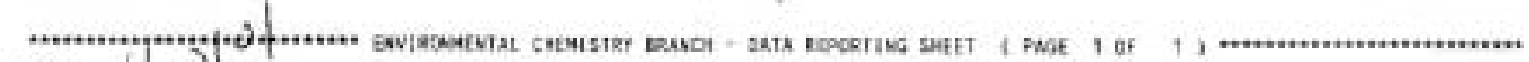

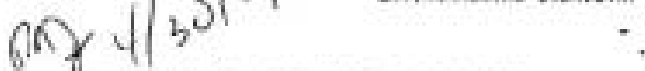

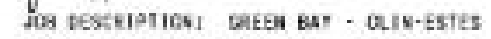

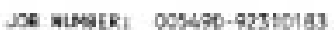
THPE of SAPIEI SEDINEMT

ketrelpt axte: is wa to constion ant5: 53 efs 0 Duch, paeseruslive:

$\begin{array}{lll}z^{+} & 3 & 6 \\ 100 & 506 & 900 \\ \text { oeg } & \text { TaPH } & 085-\mathrm{ka}\end{array}$

sev ; tescolatios

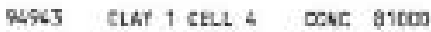

3riapot

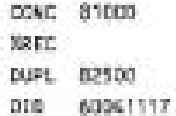

1560

dis 60361517

1

55901107

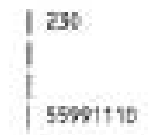

\#1) 390

i

I 5500170

No44 Dar 2 cril 6

$$
\text { 3/7ant }
$$

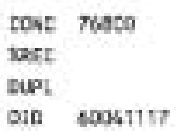

1450

1

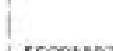

$\left\{\begin{array}{l}130 \\ 55001110\end{array}\right.$

a1] 250

1

1

1 ssovite

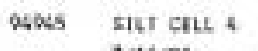
I/15,01
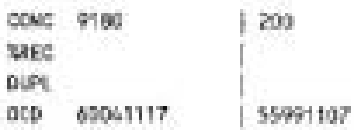

$\left\{\begin{array}{l}48 \\ 55001110\end{array}\right.$

et] $11 \mathrm{e}$

i

| 5500110

buot metuco alase of bove $\$ 700$
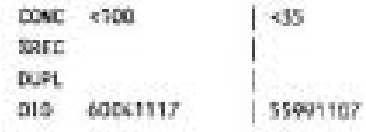

$\left\{\begin{array}{l}65 \\ 55 \%+1100\end{array}\right.$

1| 135

i

I 5501100

3Laj2 Les 01

Luac 11200

$\operatorname{sarc} 112.0$

supi

OID SCOb1117

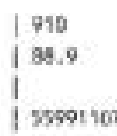

$\mid \begin{aligned} & 527 \\ & 50.5 \\ & 55991110\end{aligned}$

at | 021

| the.

1

I $550+110$

stros txtetsut, oc ct
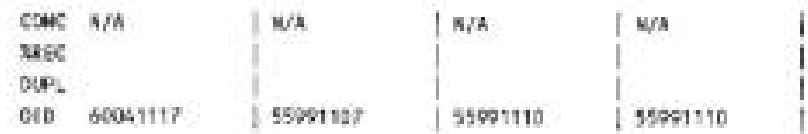

Toc Total Grganic Carbon

1025 Total Meceverable fatratean Hrocarbern

ats bil and treist

abs-in eil 5 Grase [tepcot]

Fosueres:

A) Repeat valus, axtracta 6/tapar + Set Corrective hation fara. 


\section{INTERNAL QC DATA}

Jobf11e Number: 94943

Pxoject: GRBEN BAY - OLIN-BgTEB

Account Number: D0549D-923101B3.

Date Received: 16 MAR 01

Joba Sample Tst Analyte of REC

8 SDUPL,

RPD

DID

94943

90.5

87,4

3.5

55991130

Page 1

ENT OF REPORT 


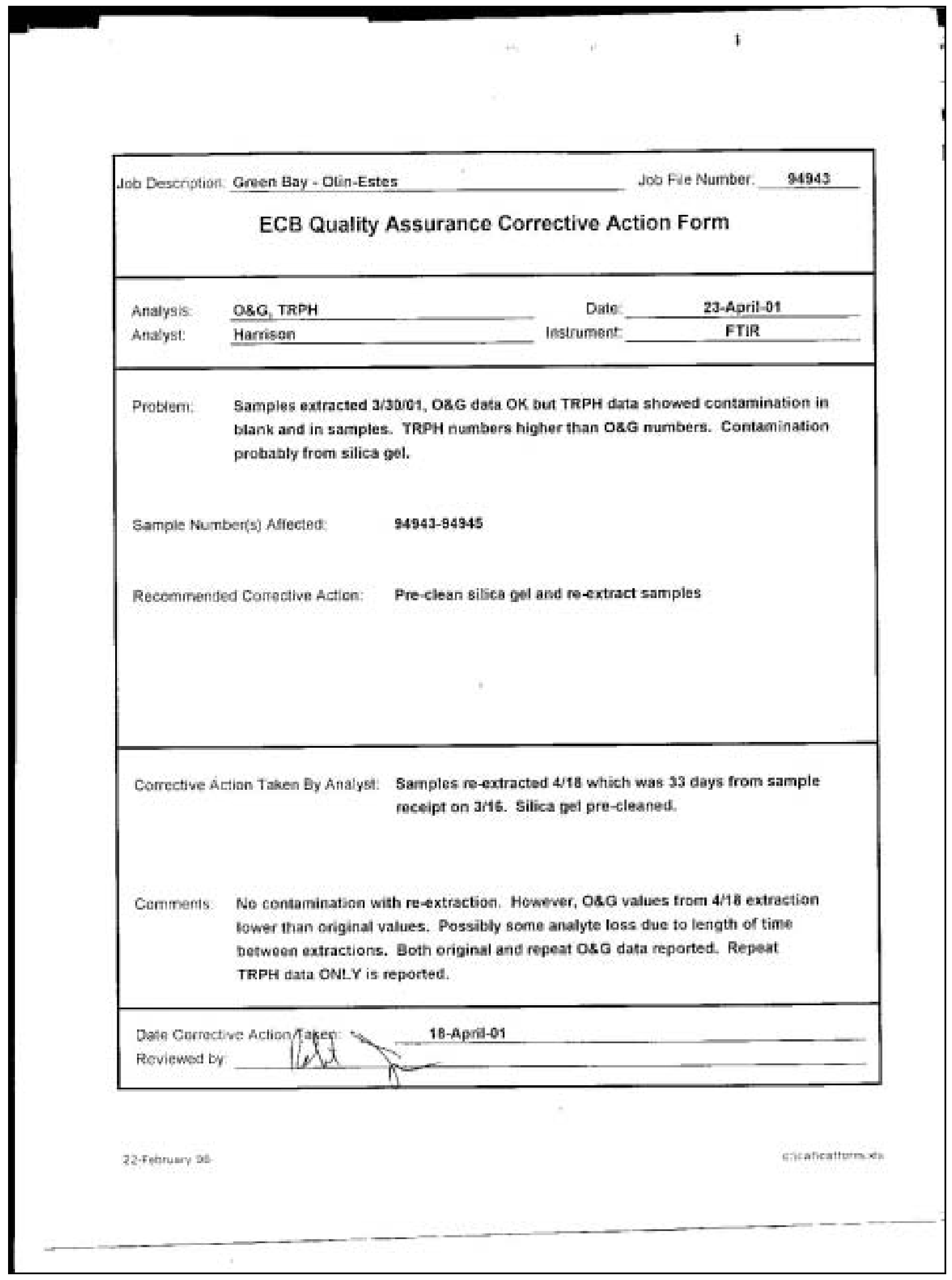




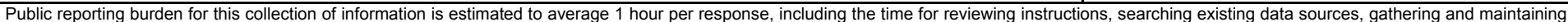

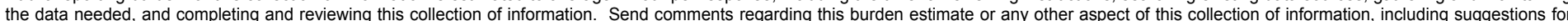

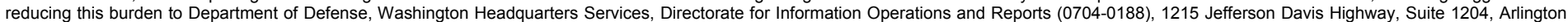

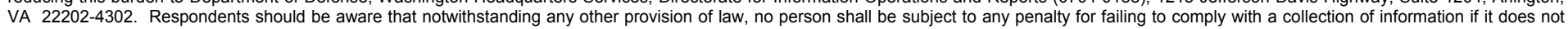
display a currently valid OMB control number. PLEASE DO NOT RETURN YOUR FORM TO THE ABOVE ADDRESS.

\begin{tabular}{l|c}
$\begin{array}{l}\text { 1. REPORT DATE (DD-MM-YYYY) } \\
\text { October } 2002\end{array}$ & $\begin{array}{c}\text { 2. REPORT TYPE } \\
\text { Final report }\end{array}$ \\
\hline
\end{tabular}

\section{TITLE AND SUBTITLE}

Soil Separation Mobile Treatment Plant Demonstration, Bayport Confined

Disposal Facility, Green Bay, Wisconsin

3. DATES COVERED (From - To)

5a. CONTRACT NUMBER

5b. GRANT NUMBER

5c. PROGRAM ELEMENT NUMBER

5d. PROJECT NUMBER

5e. TASK NUMBER

5f. WORK UNIT NUMBER

0054PD

8. PERFORMING ORGANIZATION REPORT NUMBER

ERDC/EL TR-02-38

McNamara Federal Building

477 Michigan Avenue

Detroit, MI 48226-2575

3909 Halls Ferry Road

Vicksburg, MS 39180-6199

9. SPONSORING / MONITORING AGENCY NAME(S) AND ADDRESS(ES)

10. SPONSOR/MONITOR'S ACRONYM(S)

U.S. Army Corps of Engineers

Washington, DC 20314-1000

11. SPONSOR/MONITOR'S REPORT NUMBER(S)

\section{DISTRIBUTION / AVAILABILITY STATEMENT}

Approved for public release; distribution is unlimited.

\section{SUPPLEMENTARY NOTES}

\section{ABSTRACT}

A mobile, self-contained, maximum density separator (MDS) was tested in a 1-day demonstration conducted at the Bayport Confined Disposal Facility in Green Bay, WI. The objective of the demonstration was to evaluate the ability of the equipment to separate a sand fraction meeting a given specification with respect to fines content and PCBs concentration. Additionally, two different methods of excavating and preparing the material for processing with the MDS were tested. One phase of an ongoing effort in evaluating the feasibility of soil washing techniques for volume reduction of dredged material, the field demonstration was preceded by bench-scale fractionation studies. These studies were conducted to determine the magnitude and distribution of contaminants in the material to be processed, and expected contaminant levels in the product streams. The demonstration was the culmination of research into the implementation and interpretation of fractionation studies; type, availability, and suitability of off-the-shelf equipment for sediment processing; and site visits to view different physical separation plant configurations. The results of these cumulative efforts will ultimately be incorporated into summary guidance documents.

\begin{tabular}{|ll}
\hline 15. SUBJECT TERMS & Hydrocyclone \\
Dredged material & Maximum density separator \\
Fractionation studies & MDS \\
\hline 16. SECURITY CLASSIFICATION OF:
\end{tabular}

16. SECURITY CLASSIFICATION OF:

\begin{tabular}{|l|}
\hline a. REPORT \\
UNCLASSIFIED
\end{tabular}

b. ABSTRACT

UNCLASSIFIED

\begin{tabular}{l|} 
c. THIS PAGE \\
UNCLASSIFIED
\end{tabular}

PCBs

Sediments

Soil separation

17. LIMITATION
OF ABSTRACT

18. NUMBER

OF PAGES

229
Soil washing

Volume reduction

19a. NAME OF RESPONSIBLE PERSON

19b. TELEPHONE NUMBER (include area code) 